Fall 1951

\title{
1951 Cedrus Yearbook
}

\section{Cedarville College}

Follow this and additional works at: https://digitalcommons.cedarville.edu/yearbooks

Part of the Higher Education Commons, Organizational Communication Commons, and the Public Relations and Advertising Commons

\section{Recommended Citation}

Cedarville College, "1951 Cedrus Yearbook" (1951). Yearbooks. 63.

https://digitalcommons.cedarville.edu/yearbooks/63

This Book is brought to you for free and open access by DigitalCommons@Cedarville, a service of the Centennial Library. It has been accepted for inclusion in Yearbooks by an authorized administrator of DigitalCommons@Cedarville. For more information, please contact digitalcommons@cedarville.edu. 
B.

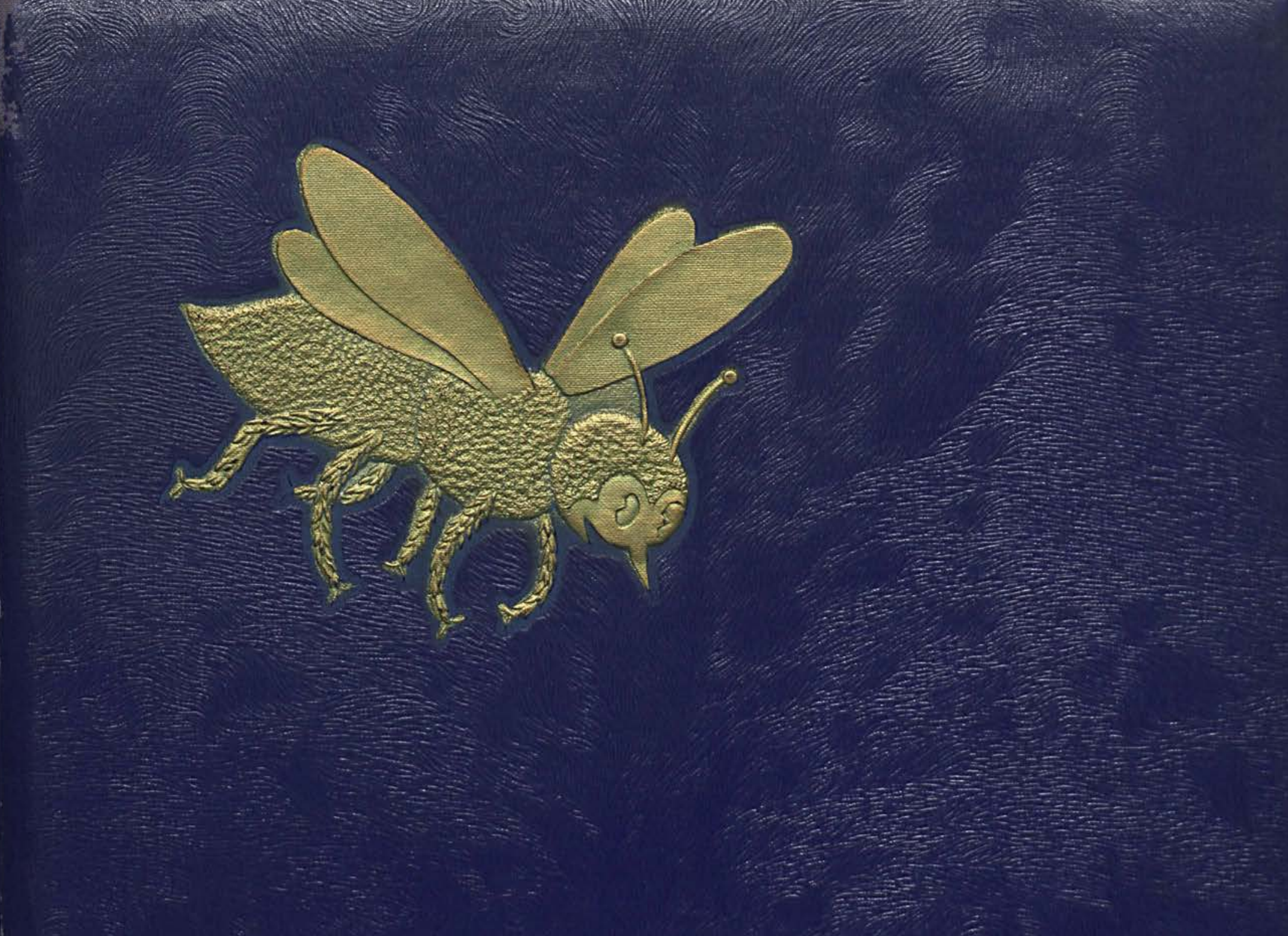

378.7714

c 389

1951

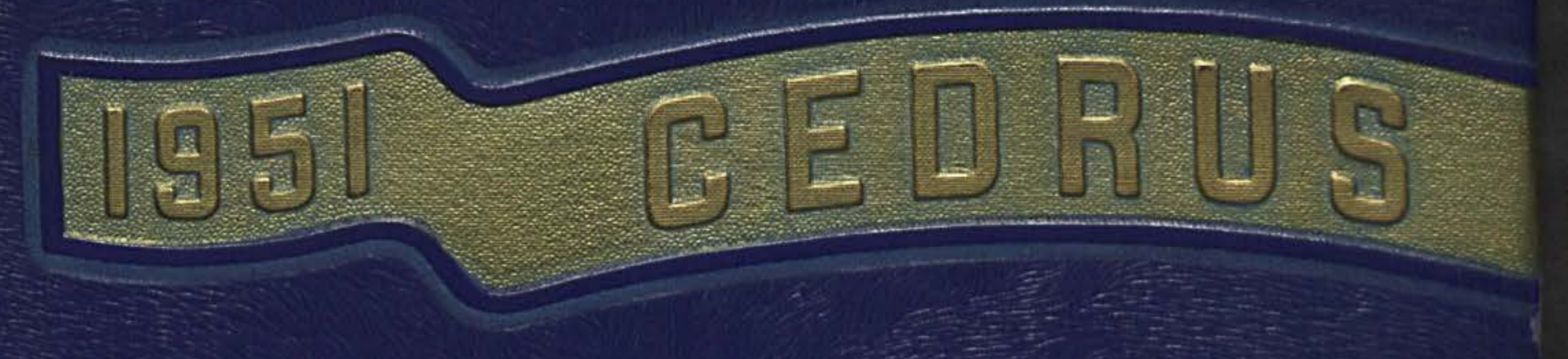




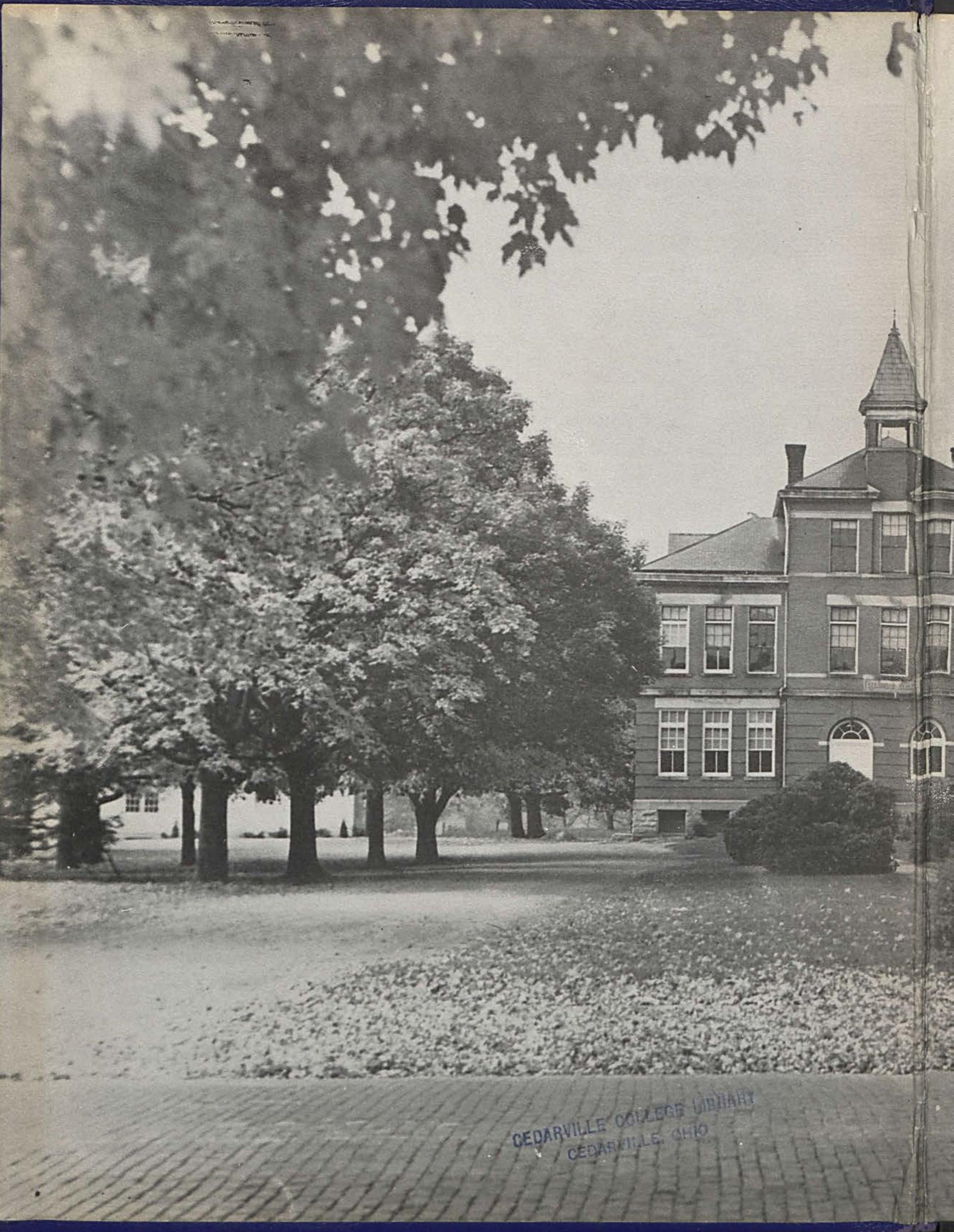




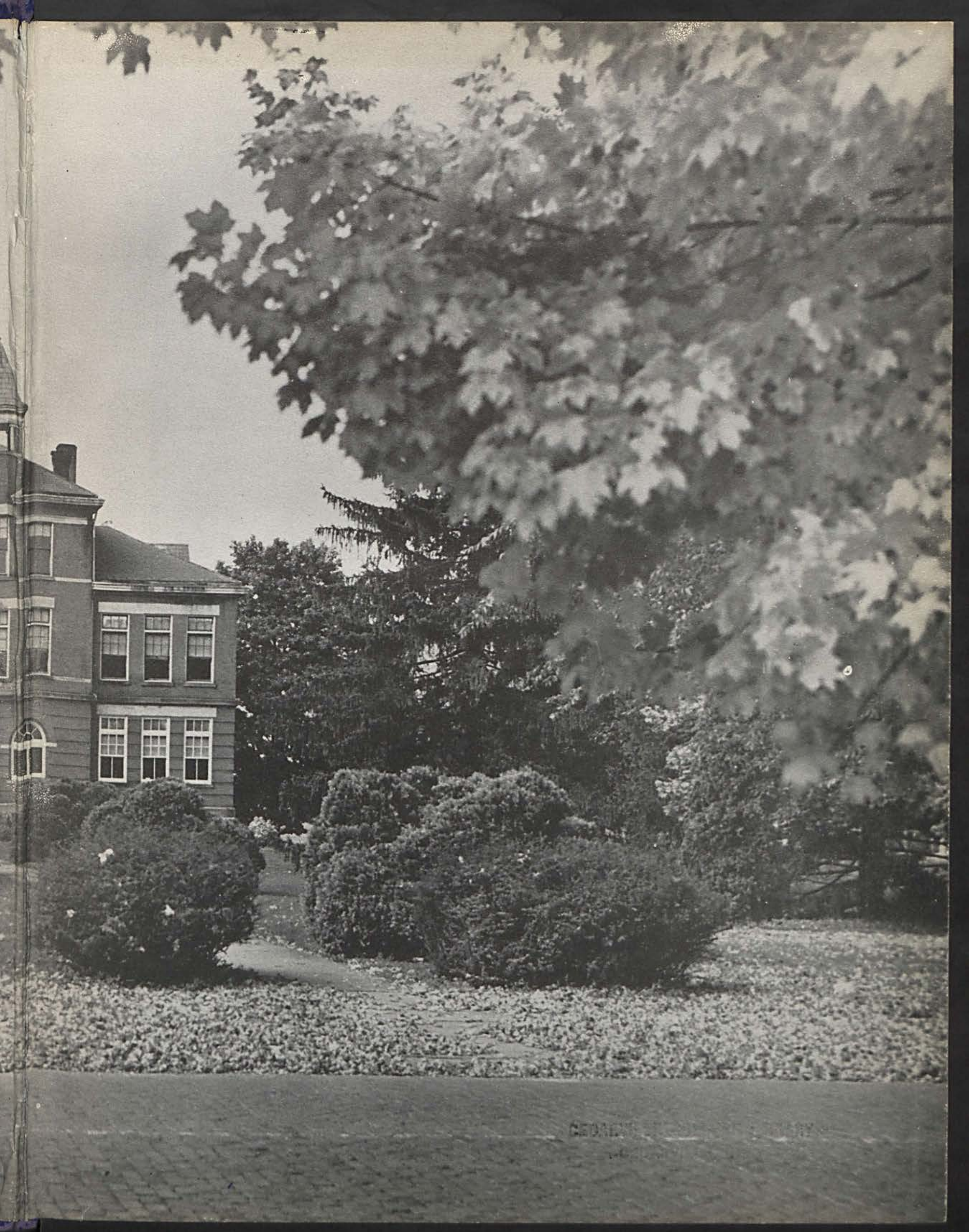




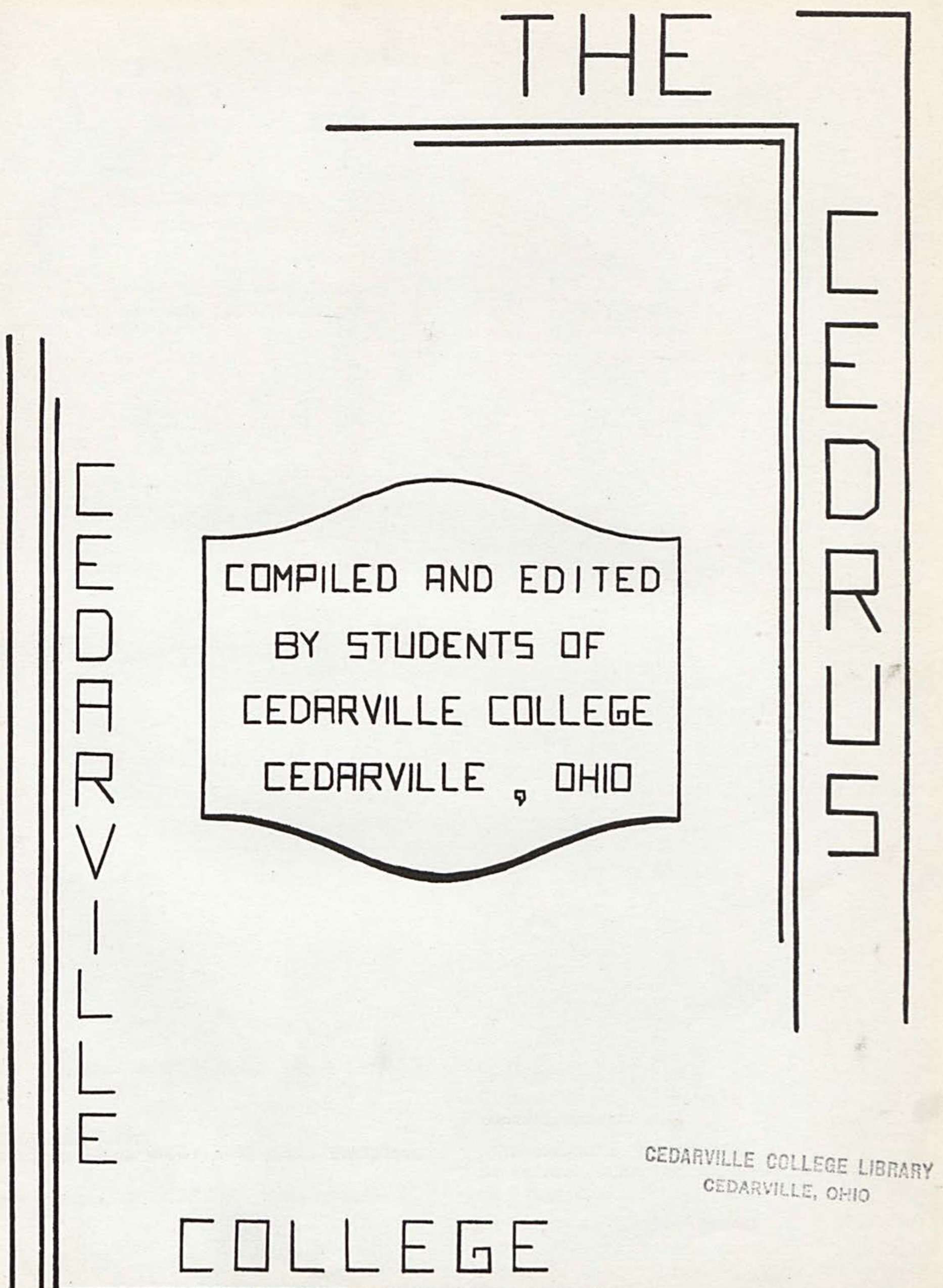


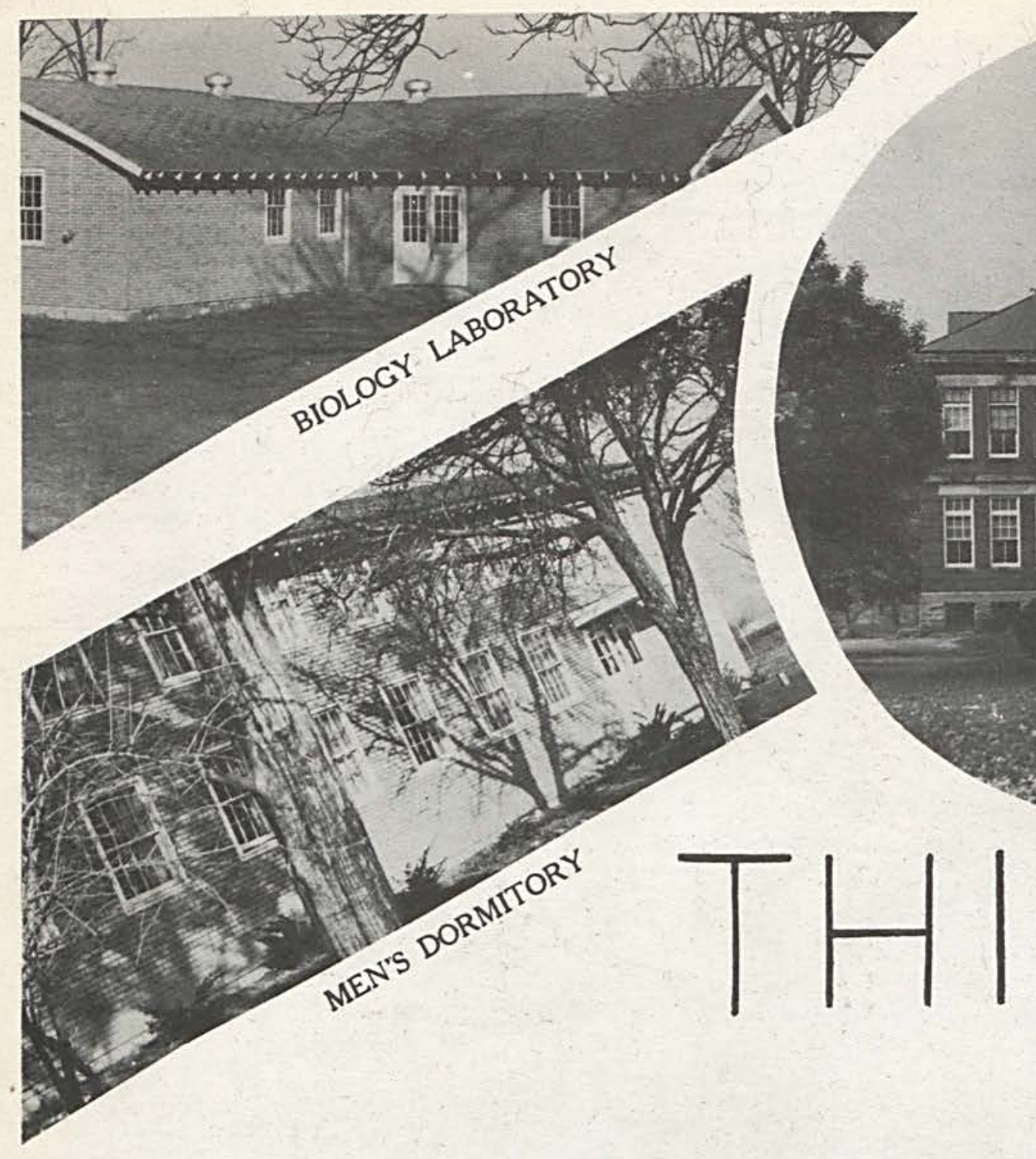

\section{ADMINISTRATION}

SCIENCE HALL
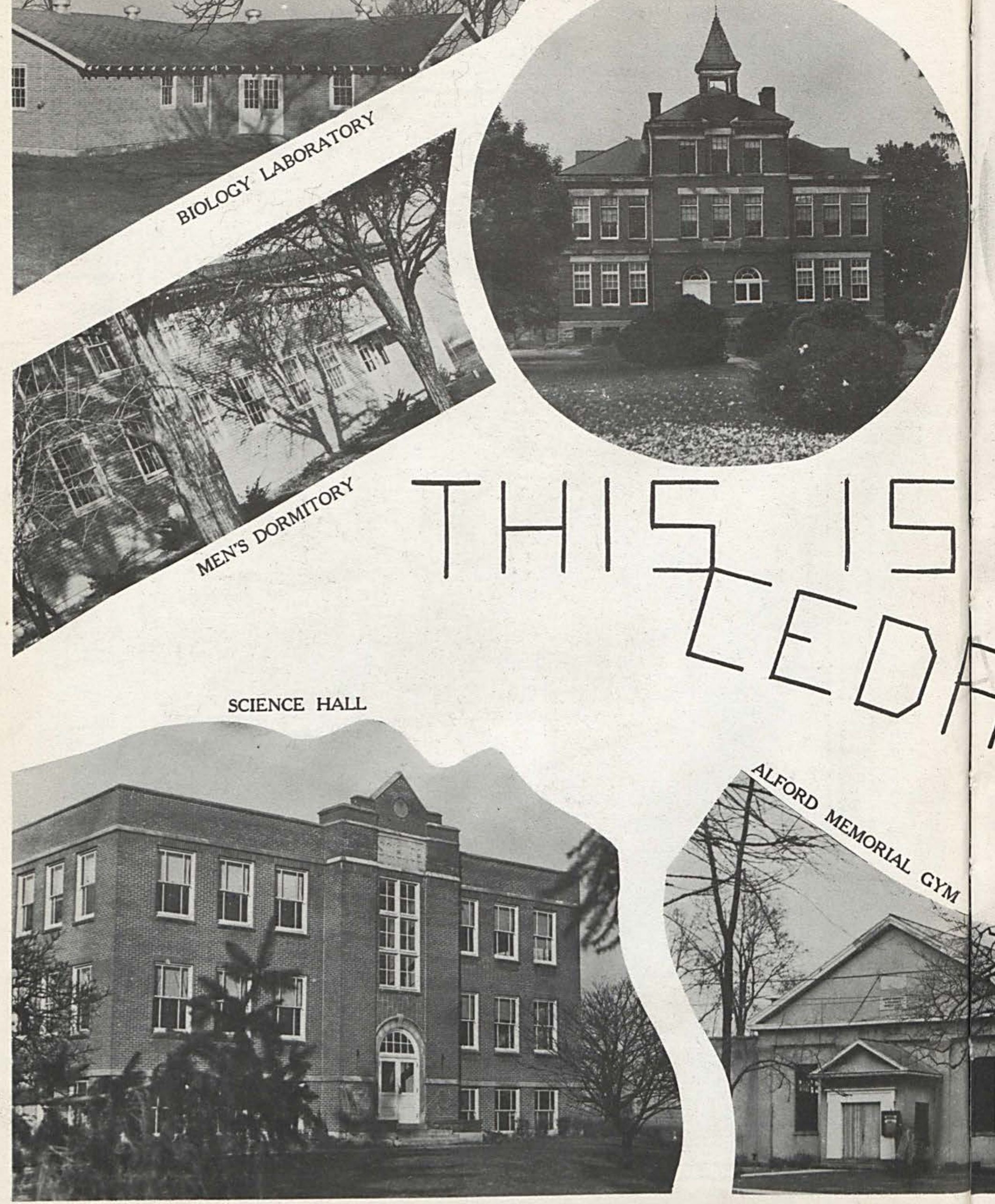
(3)

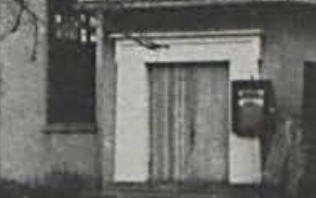




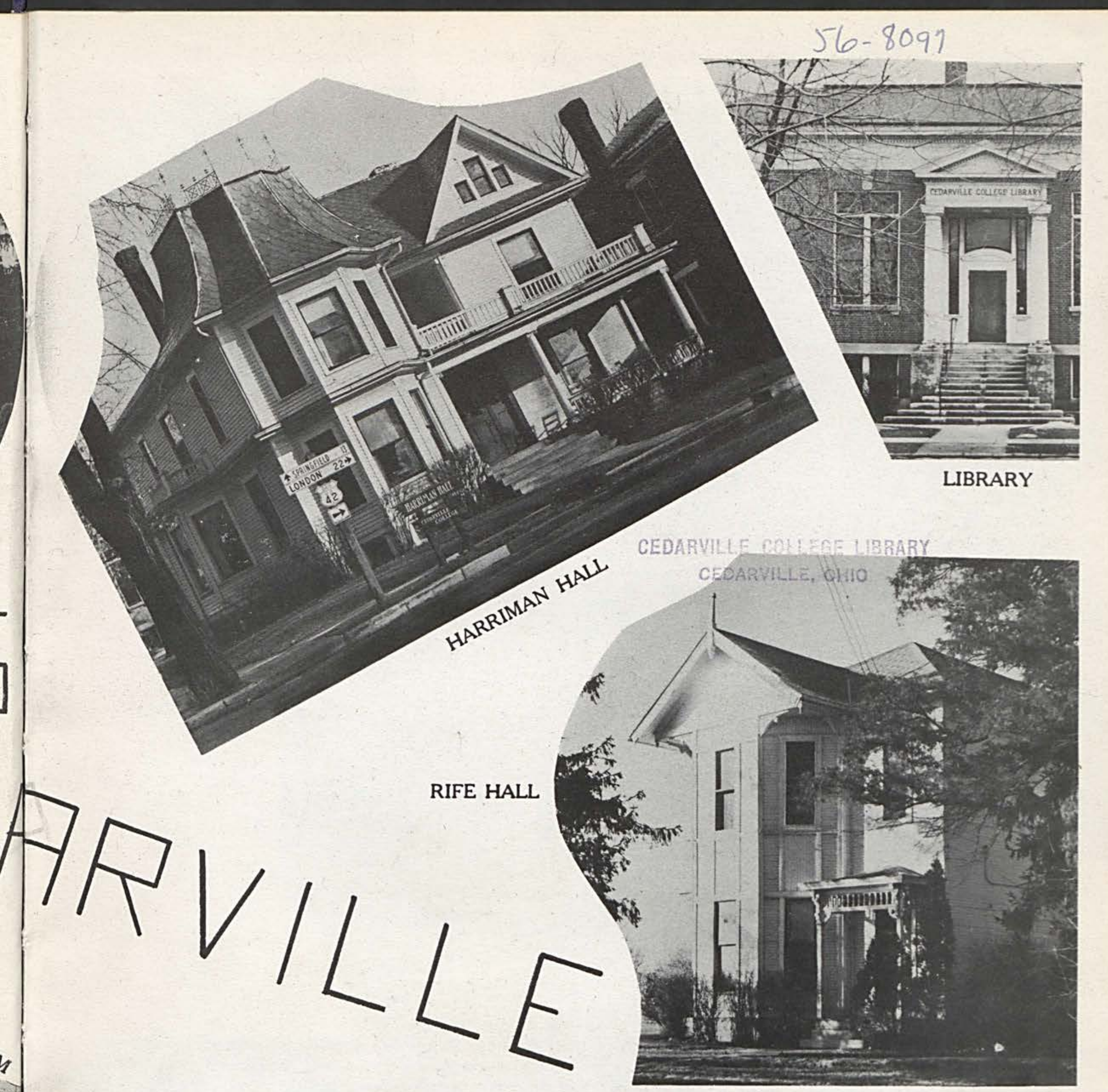

5

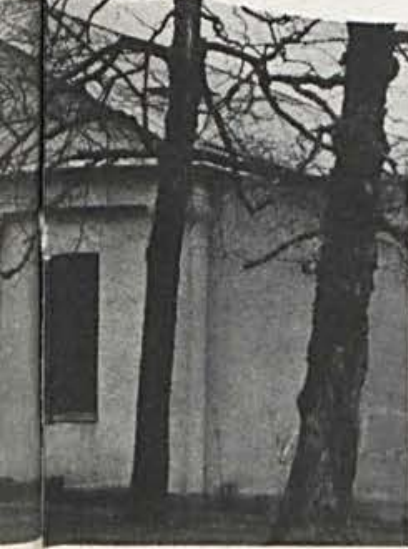

RECREATION HALL

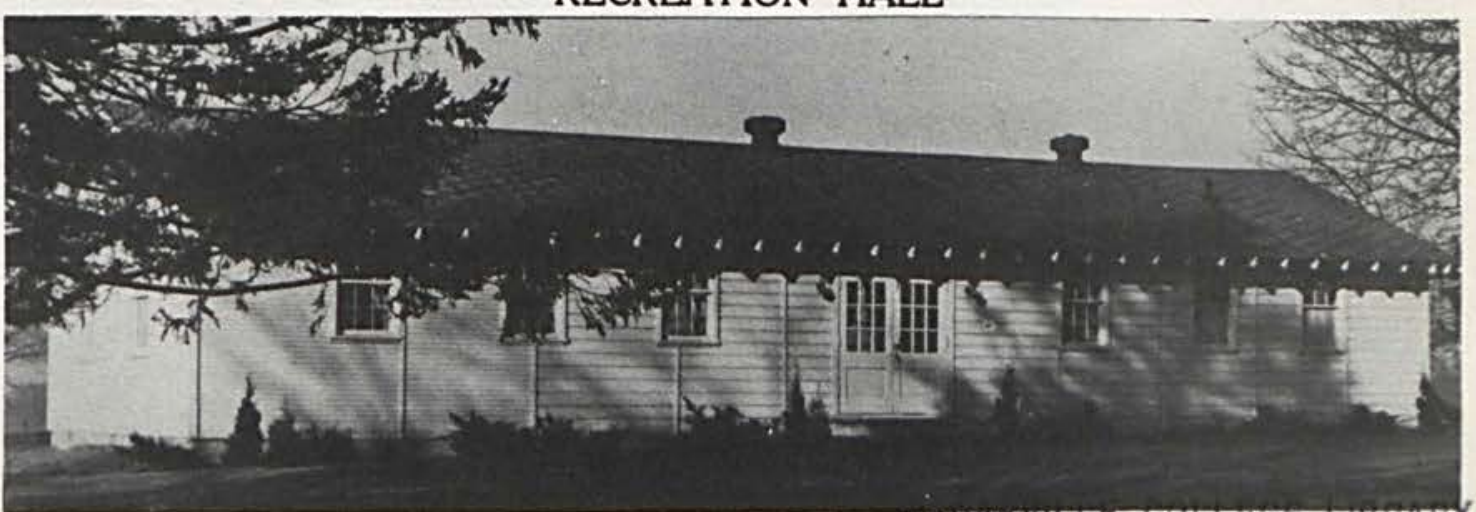




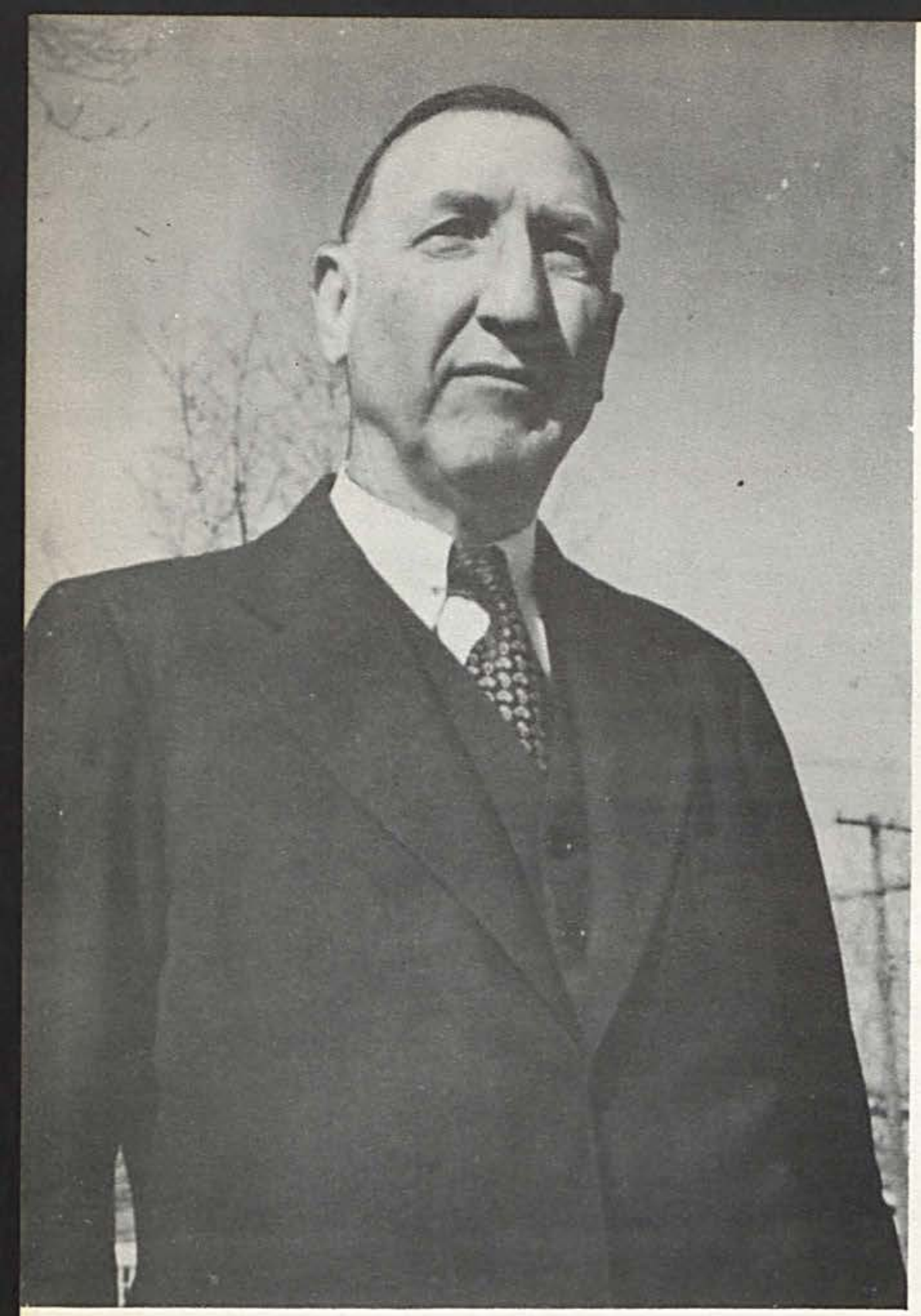

He seemed as one of us to sit, And talk of things above, below, With flames more winsome than our wit, And words that burned like fire aglow.

\section{Dr. Frank Albert Jurkat, A.B., A.M., LL.D.}

-who for fifty-six years has taught classic and modern languages at Cedarville College, having several times refused offers from larger and more famous institutions in order to devote his life to the needs of the students of this college.

We dedicate this, the 1951 Cedrus, to him because, although a man of prodigious learning, he wears that learning lightly; because, like Yorick, the is a man of infinite jest;' because an hour of one of his classes is a delight to those who share it, when not only mind and spirit are fed with wit and visdom, but the flesh too is sustained by the cookies and candy that he carries up the campus path in his market basket along with books-and, above all, because he is loved and greally admired, and remembered by his students long after their other teachers have been forgotten. 


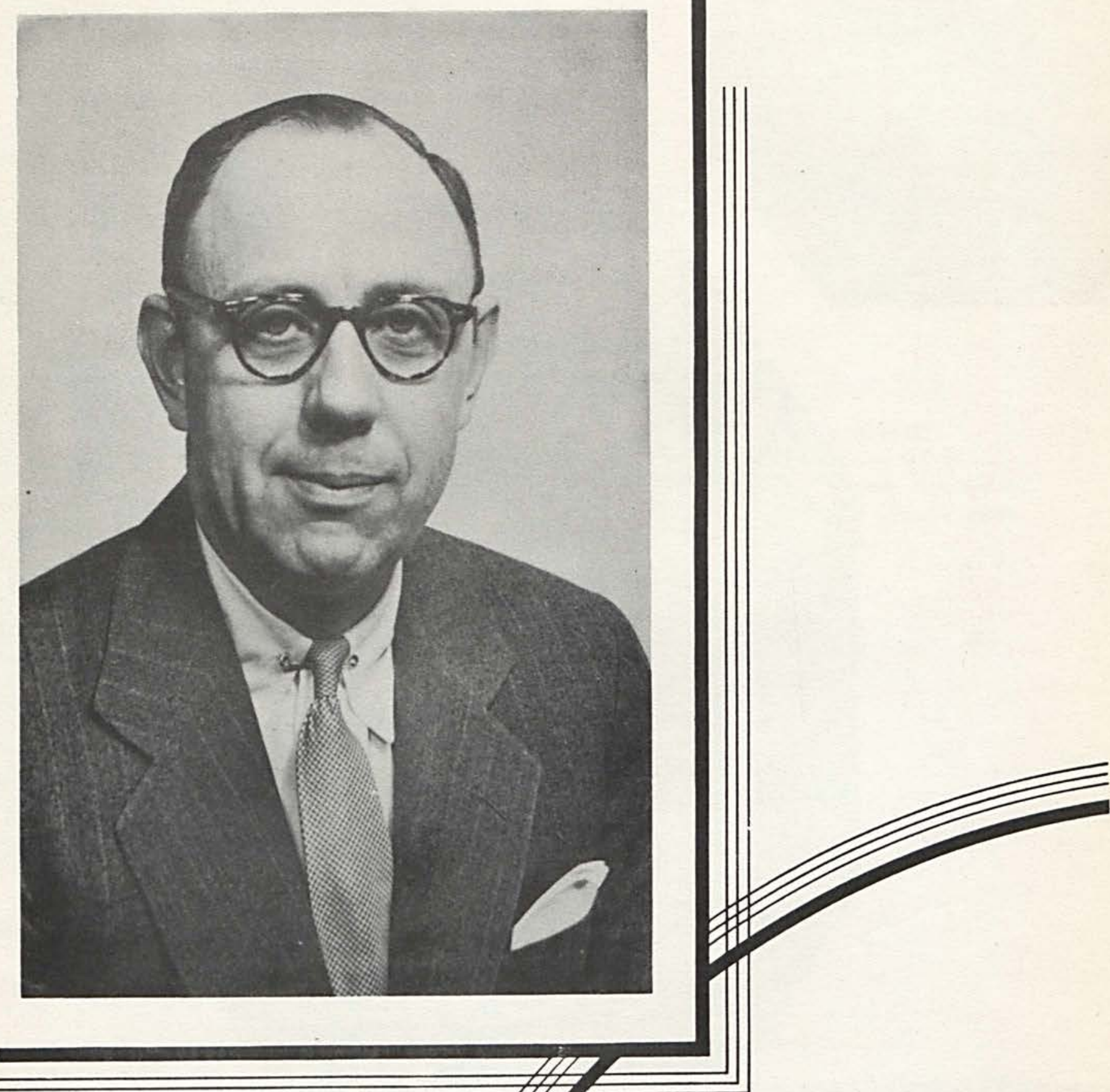

\section{E. H. MILLER, Acting President}

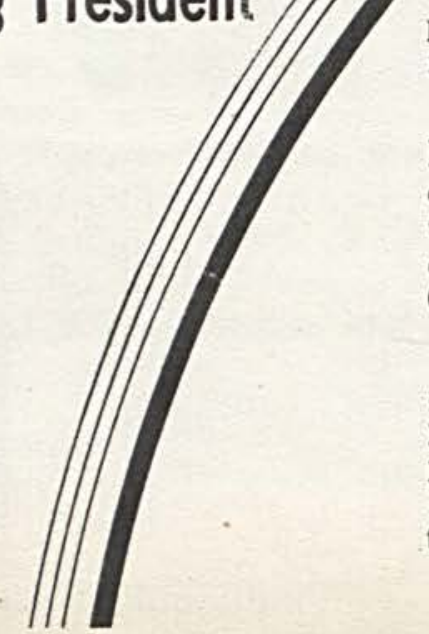

This, my first year at Cedarville College, has been a pleasant and challenging one. I have been much impressed by the quality of the students, the loyalty of the faculty, and the cooperation of trustees and alumni.

Although there can be no doubt that critical times lie ahead, the security of our nation and the vitality of our society would both be assured if future citizens of the nation cherished the same high ideals and strength of character which are so apparent in the Cedarville College community.

When you leave this campus and take on the responsibilities of a broader life, it is our hope that what you thought here, did here, and dreamed here will have providid you with the determination to serve well your fellow man. There can be no greater goal in life than this.
E. H. MILLER, Acting President. 


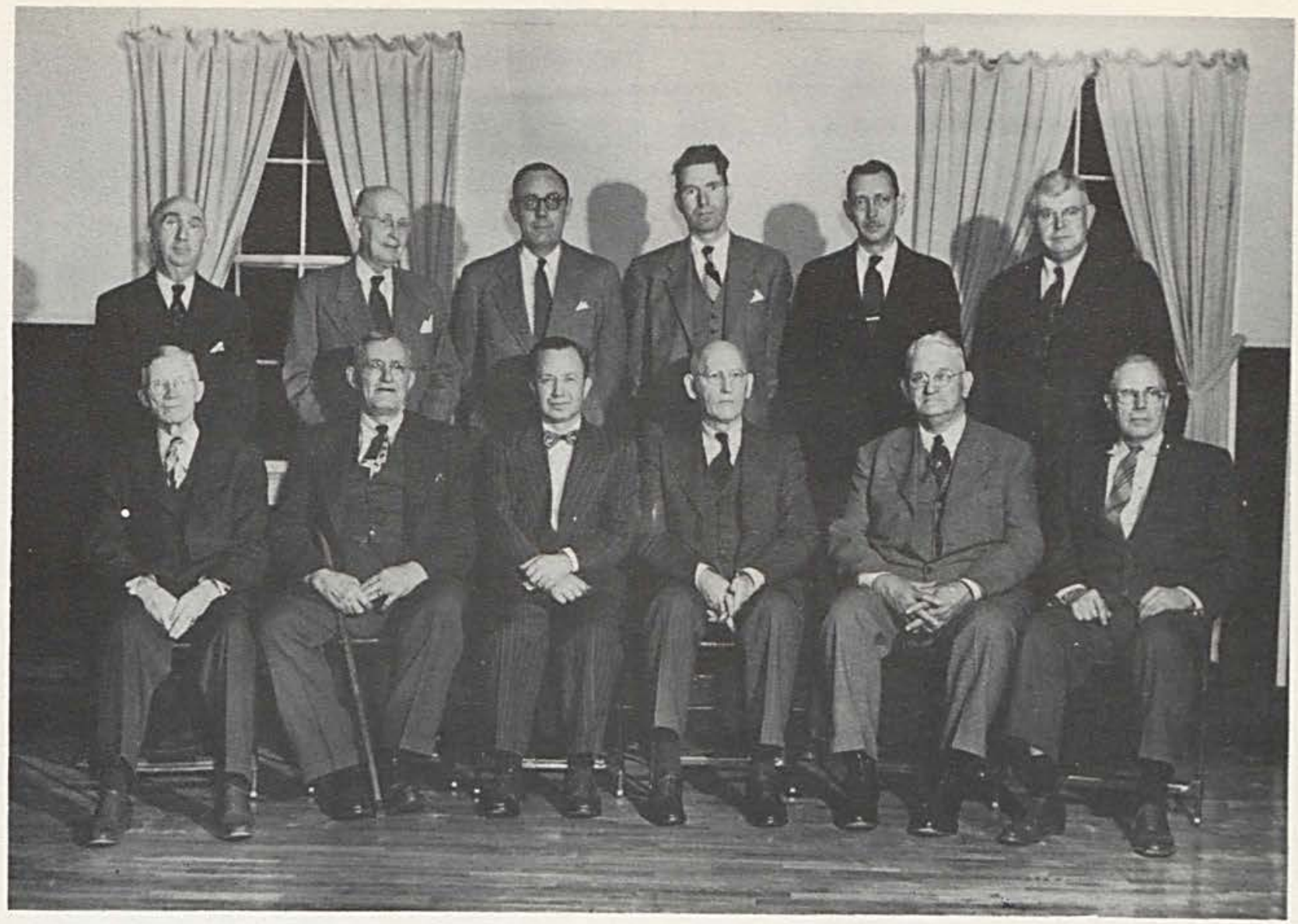

First Row, left to right: Walter C. Iliff, George H. Hartman, Harvey Auld, Joseph A. Finney, Dr. Leo Anderson, Earl McClellan. Second Row, left to right: R. W. Ustick, Karlh Bull, E. H. Miller, Donald F. Kyle, Harold Ray, David Bradfute.

\section{BOARD OF TRUSTEES}

Leo Anderson, D.V.M., Veterinarian

TERMS EXPIRE 1951

John W. Bickett, D.D., '97, Minister

Karlh Bull, Publisher

Joseph A. Finney, 06, Attorney-At-Law

Ralph Rife, '22, Farmer

R. W. Ustick, D.D., '16, Minister

TERMS EXPIRE 1952

Willard Barlow, '27, Educator

David Bradfute, 16, Postmaster

Donald Kyle, M.D., Physician

Rankin McMillan, Farmer

Cedarville

Clifton

Cedarville

Cedarville

Springfield

TERMS EXPIRE 1953

Earl McClellan, Hatchery

Harold Ray, Doctor.

George B. Hartman, Merchant

W. C. Iliff, Contractor

Harvey C. Auld, Banker

Leslie Dean, Doctor

John Dorst, Emeritus

Columbus Xenia

Cedarville

Cedarville

\section{OFFICERS}

J. A. Finney

Dr. Leo Anderson

Harvey Auld

George Hartman

E. H. Miller

Xenia Xenia Cedarville Cedarville Springfield Rocky River, Ohio Springfield

President Vice Pres. Secretary

Treasurer 


\section{STAFF}
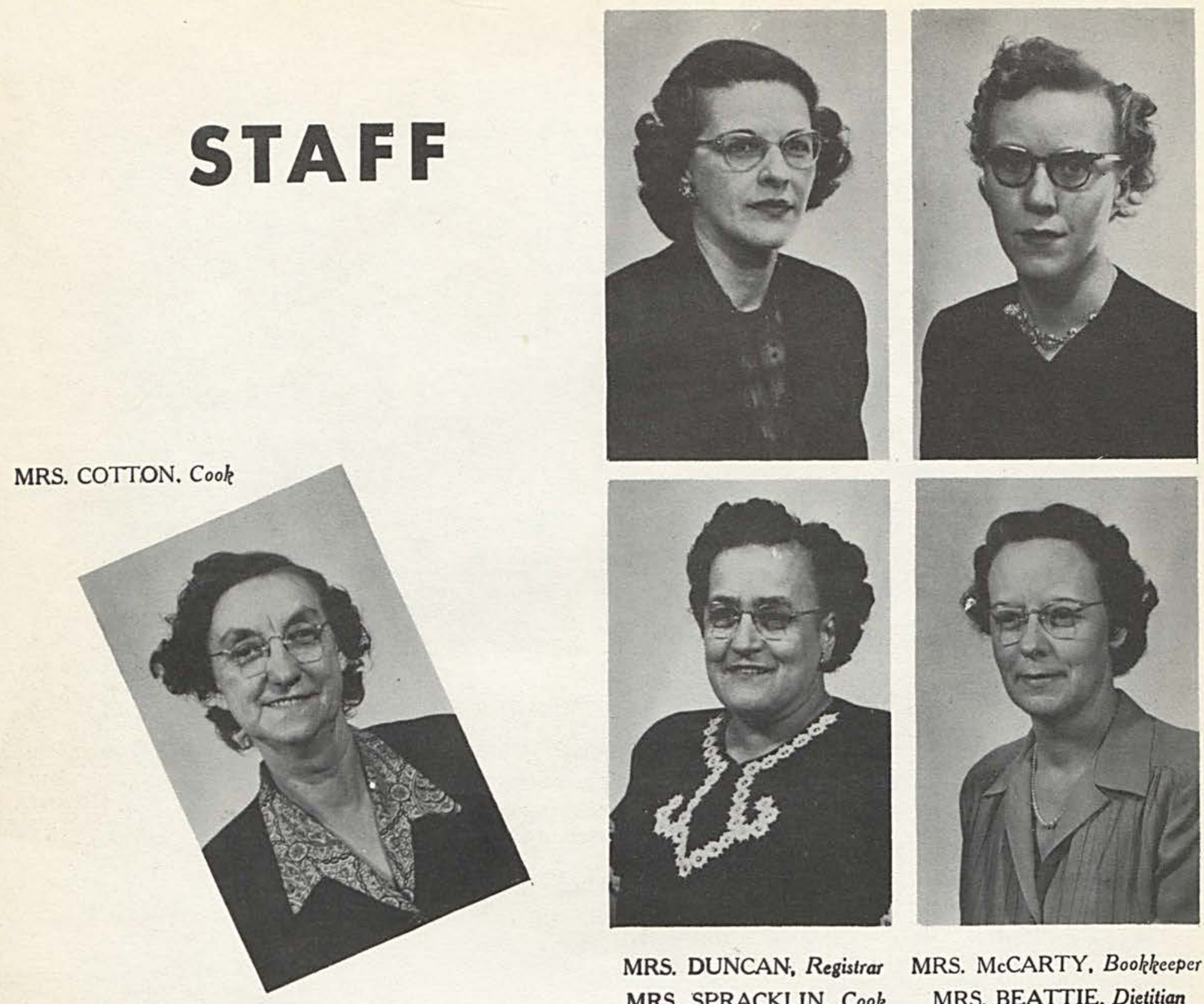

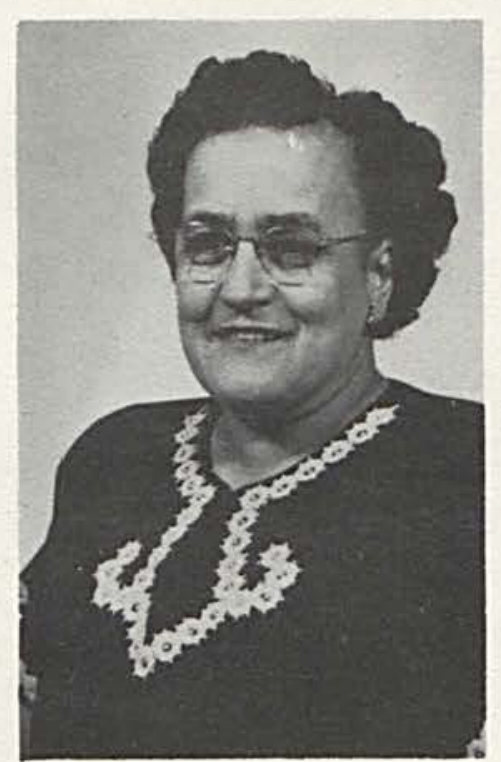

MRS. DUNCAN, Registrar MRS. SPRACKLIN, Cook

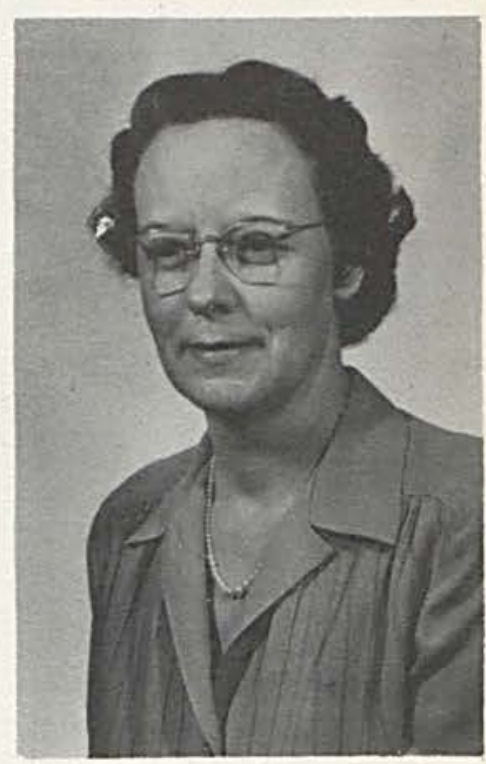

MRS. McCARTY, Bookleeper MRS. BEATTIE, Dietitian

MISS WILLIAMSON, Librarian
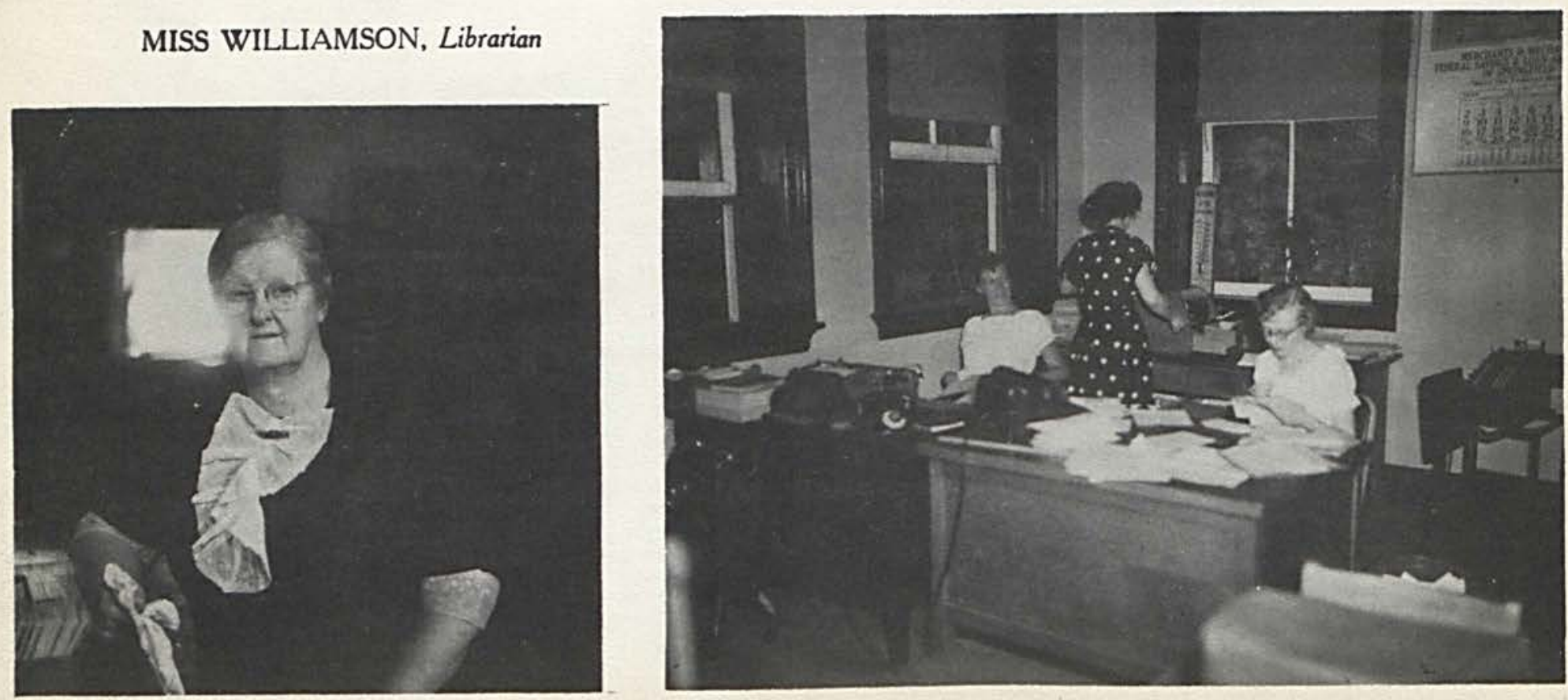


\section{STUDENT ASSISTANTS}

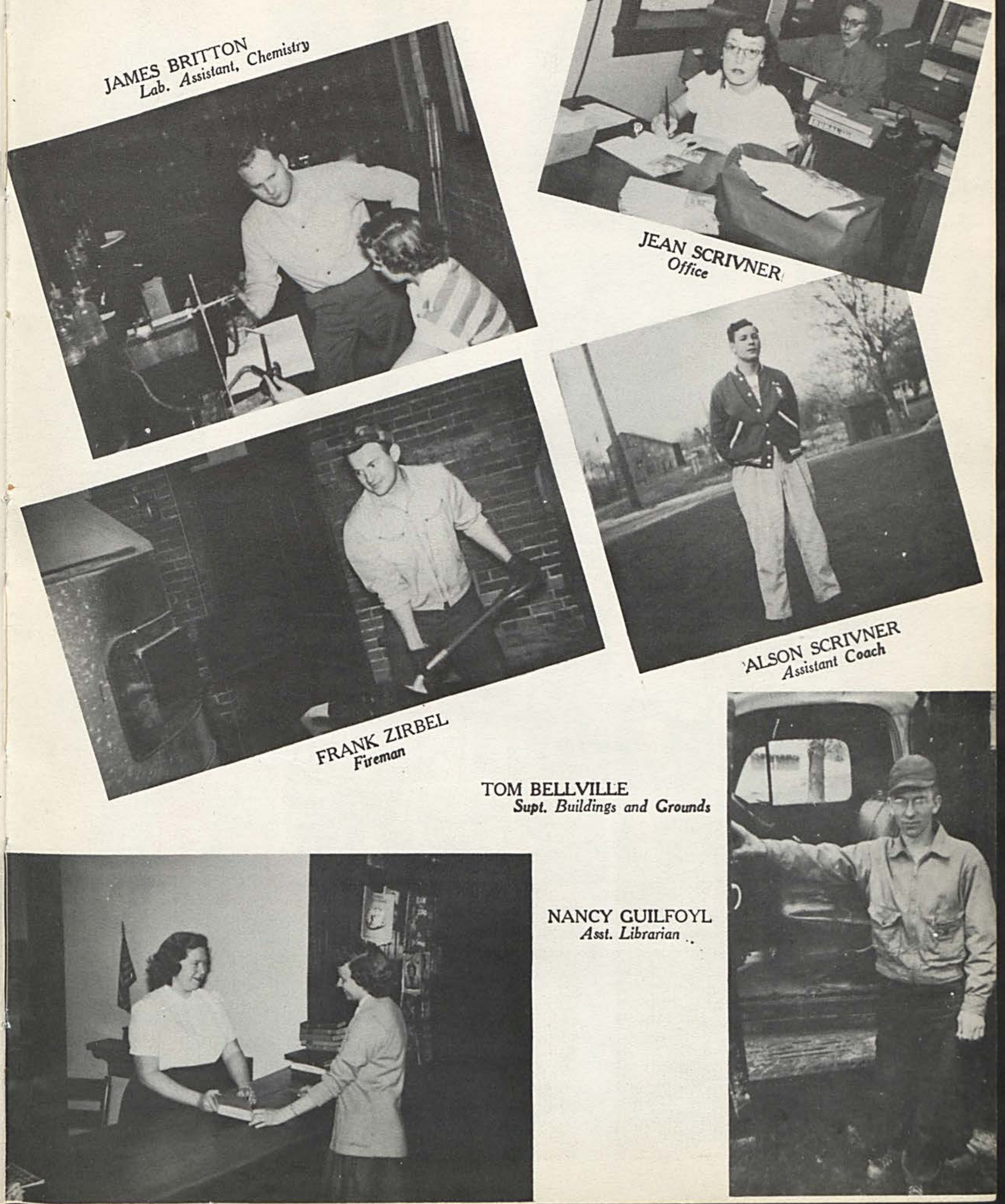




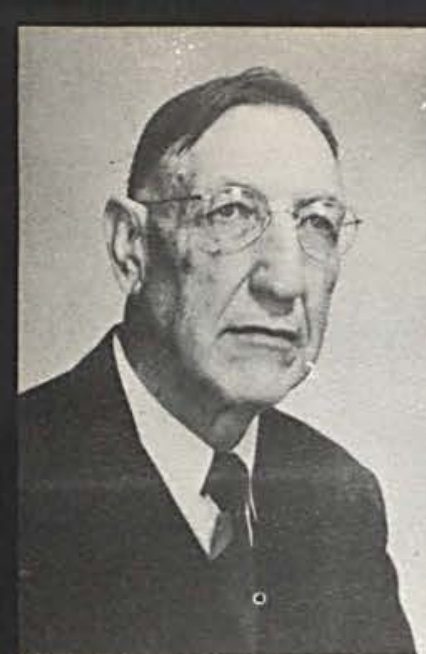

DR. F. A. JURKAT Languages

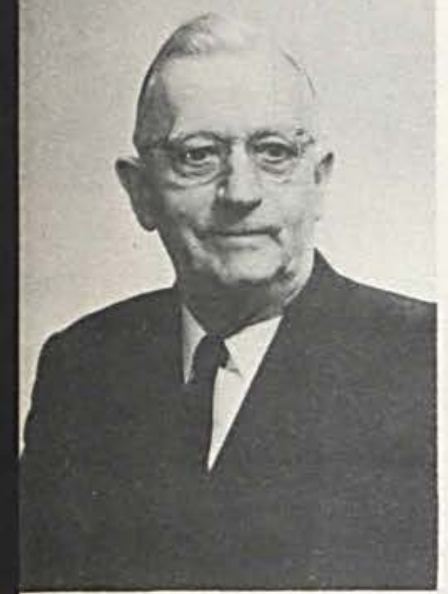

DR. C. W. STEELE Emeritus

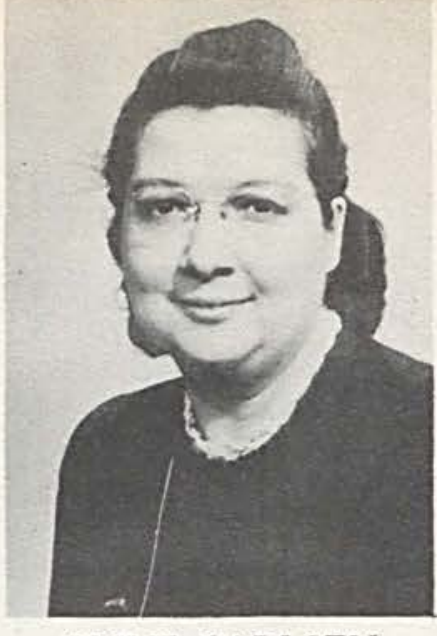

OLIVE CARLSEN English

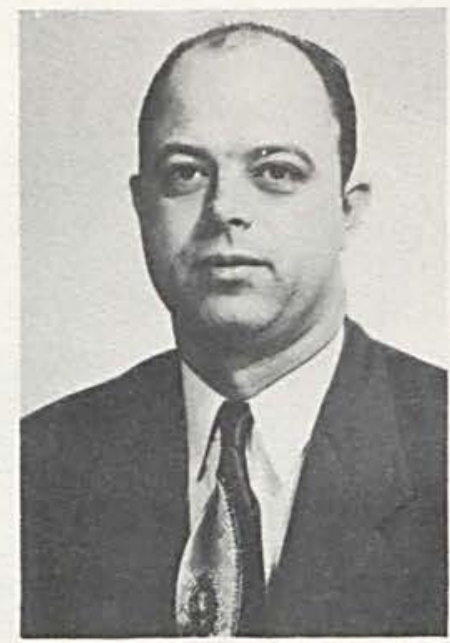

HOWARD L. WISE Mathematics

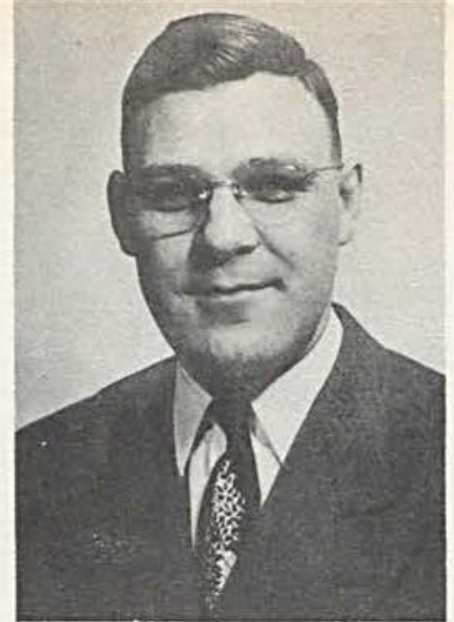

FREDERICK CARLSEN Bible

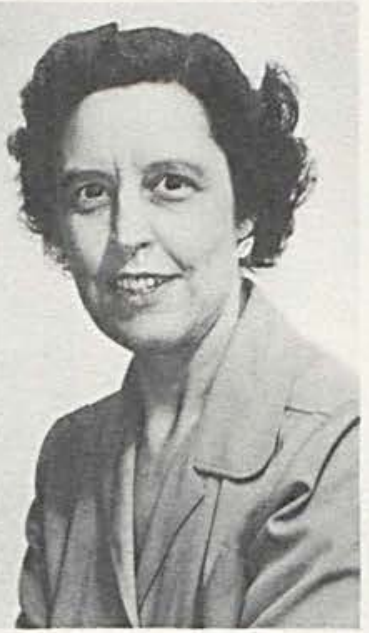

ELOISE KLING Elementary Education

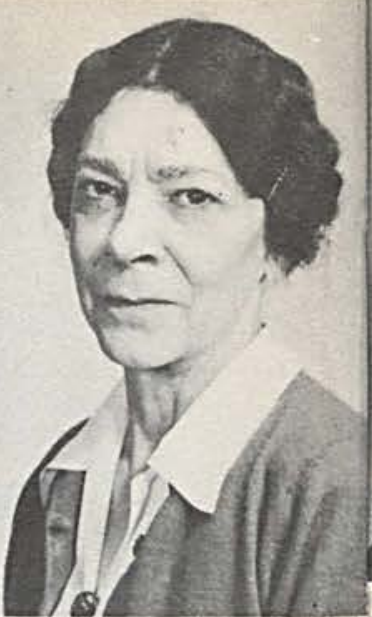

HELEN SANTMEYER Literature

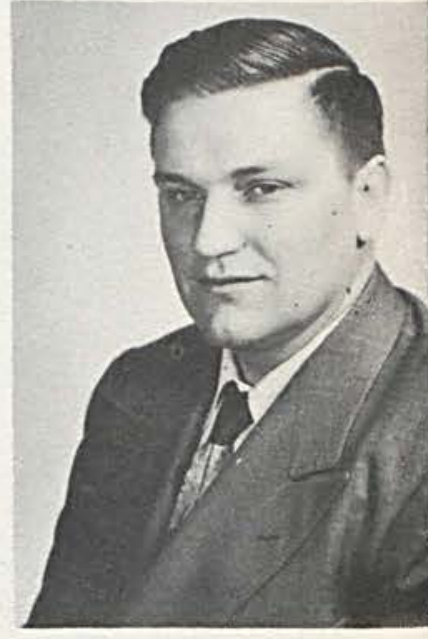

ELWOOD R. SHAW Physical Sciences

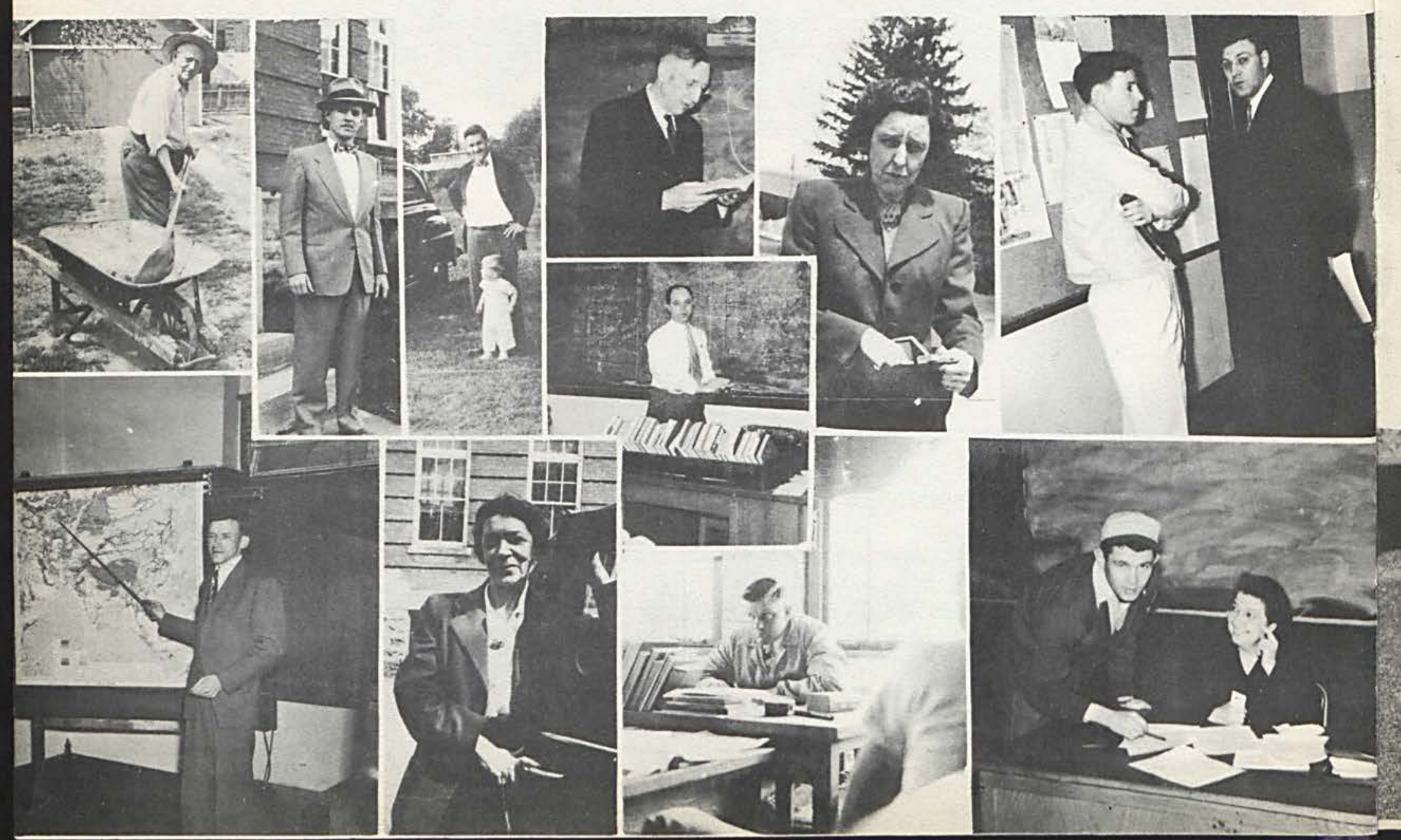




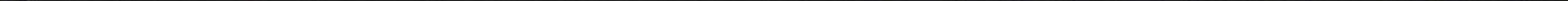




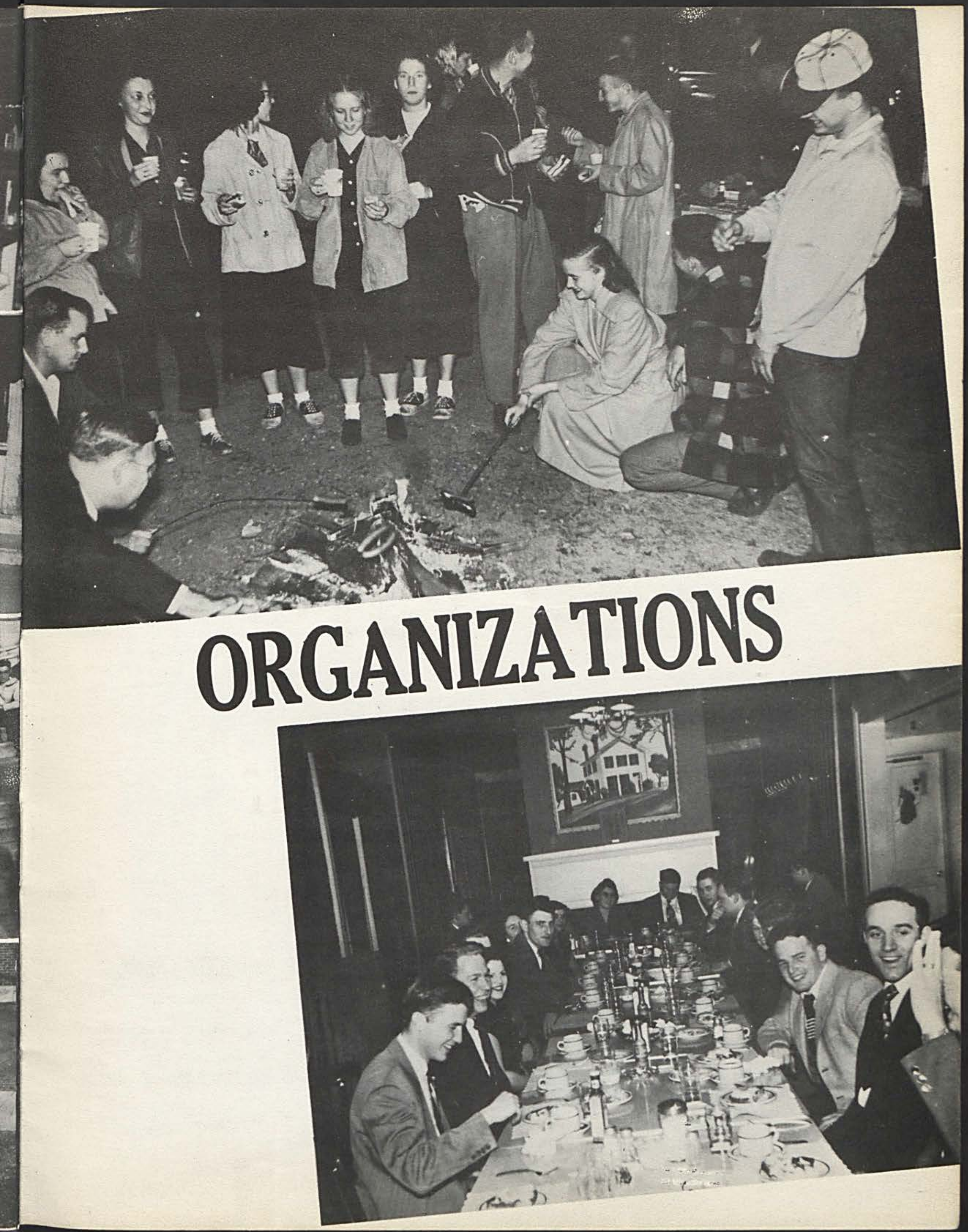




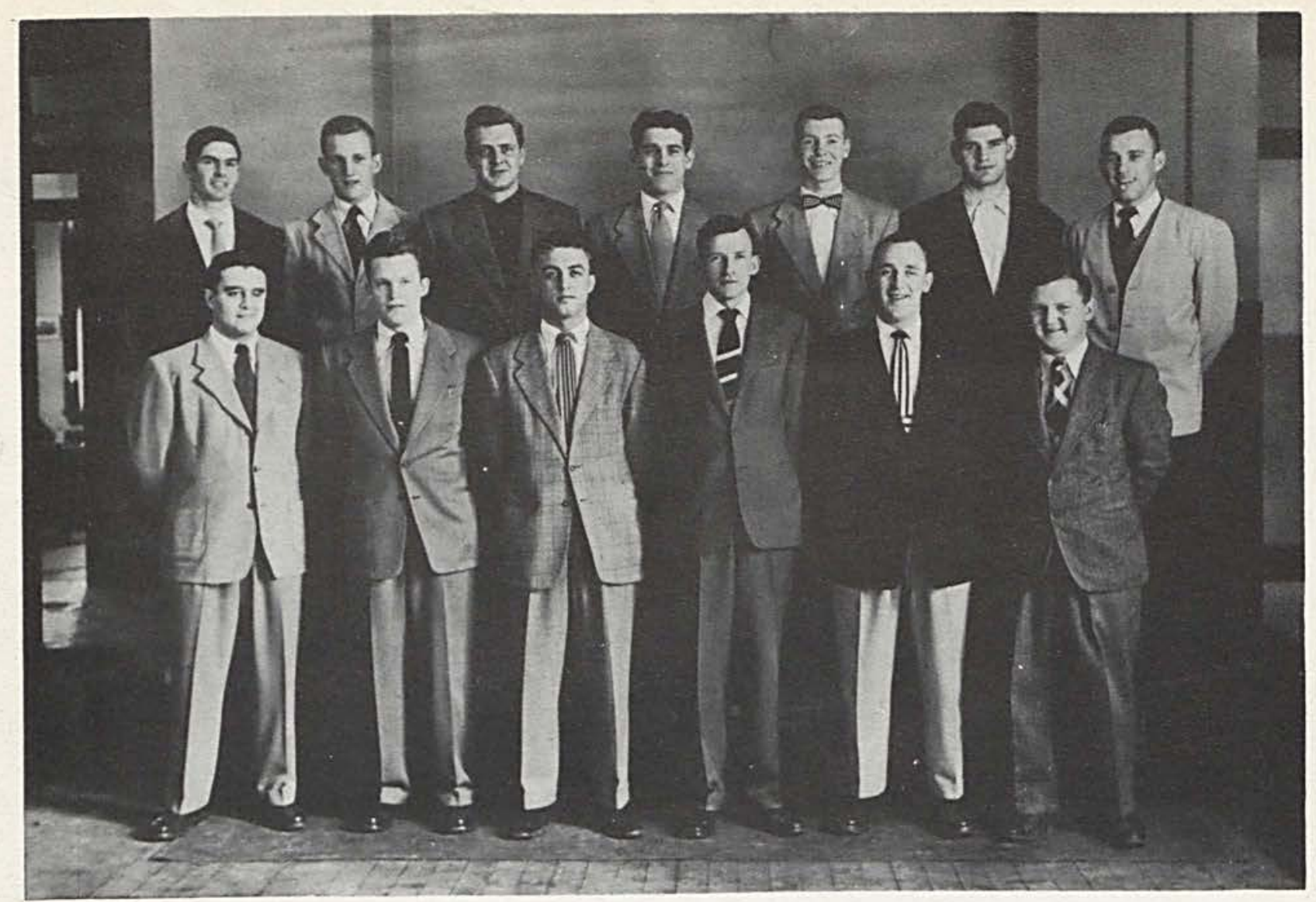

First Row, left to right: Mike DiStaola, Garland Cox, Pete Theobald, Donald Edington (faculty advisor), John Snowden, Paul Klontz.

Second Row, left to right: Kee Downs, Donald Staggs, Fred Long, Bob Peters, Fred Smith, Dave King, Ken Carpenter.

\section{Chi Mu Delta}

The school year 1950-1951 proved to be another active and successful one for CHI MU DELTA fraternity. Organized and founded in 1941 is has distinguished itself socially and scholastically.

During this school year, the group sponsored two all-campus social events: the annual Halloween Carnival, and the Spring Formal which completed the Cedar Day activities.
The fraternity has kept in contact with alumni members and welcomed them back to special meetings and various college events.

Officers for the past two years were: Robert Peters, president; Fred Long, vice president; Bill Purdom, treasurer; John Snowden, secretary; Dave King, sargeant-atarms. 


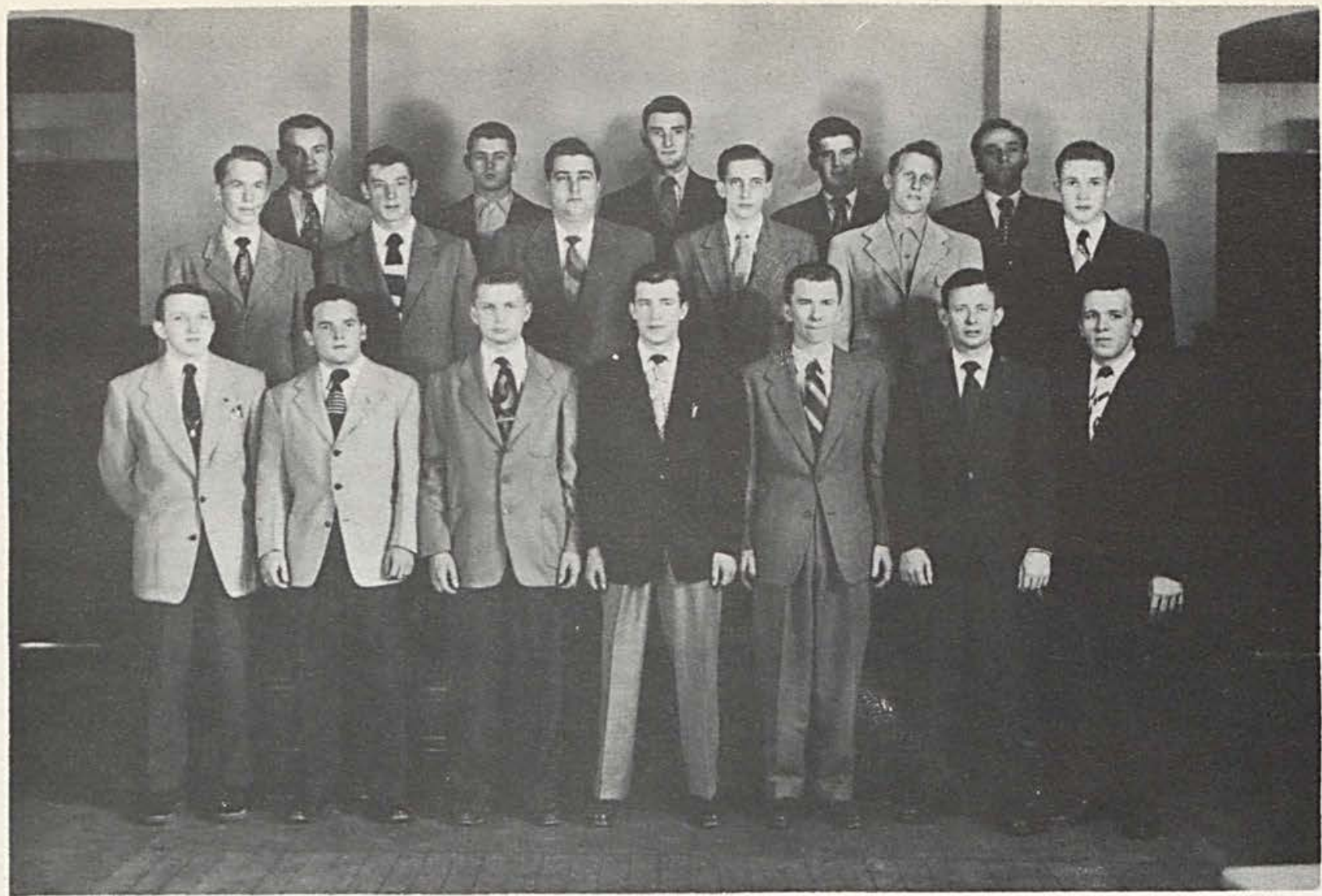

First Row, left to right: Dave Spitzer, Jim Dill, Jim Luttrell, Jim Shaffer, Tom Beilville, Bill Osman, Paul Dunn. Second Row, left to right: Jack Bellville, Henry Beattie, Eugene Fisher, Paul Fiedler, Tom Osborne, Melvin Tackett. Third Row, left to right: Frank Zirble, Darell Coe, Wayne Stevens, Dean Harner, Gene Cultice.

\section{Kappa Sigma Kappa}

OFFICERS: President Paul Dunn

Vice-President Dave Spitzer

Secretary Darrel Coe

Treasurer Dean Harner

Sgt. at Arms. Eugene Fisher

Corrs. Secretary Paul Fiedler

Reporter James Shaffer
(The Kappa Sigma Kappa Fraternity isa national fraternity established at Virginia Military Institute in September, 1867. It is now comprised of fifty chapters

reaching from British Alpha in London to Tasmania Alpha in Australia. Ohio, West Virginia and Illinois have the most chapters per state, the number being five.)

The local chapter was chartered on this campus in the spring of 1948. Since that time it has made several functions into annual events. The Christmas Formal, which gets bigger and better each year, the Easter Egg hunt for the grade school children and the regular pledge banquets and parties. K. S. K. is building to make these events better and introduce new ones into the social calender of the campus. 


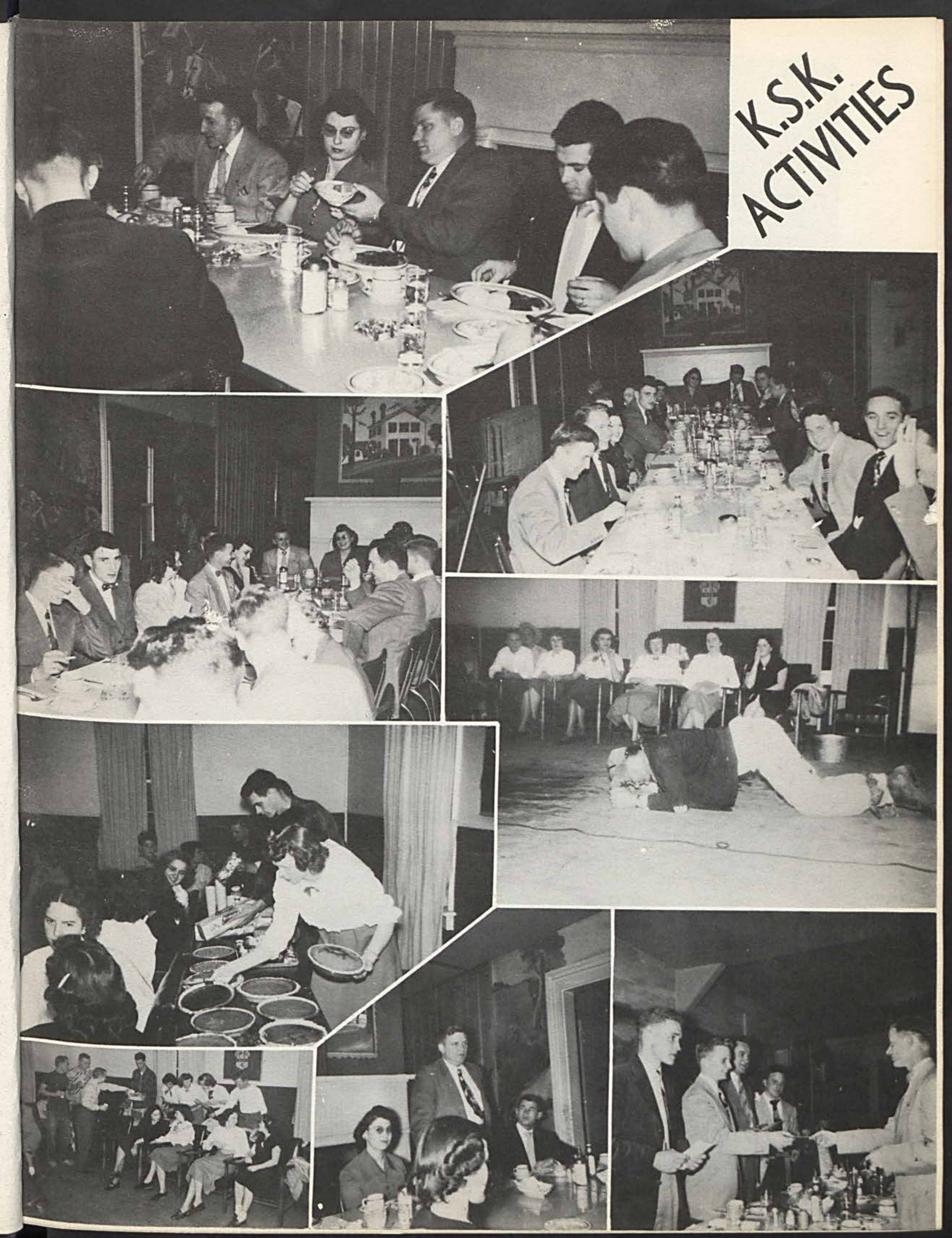




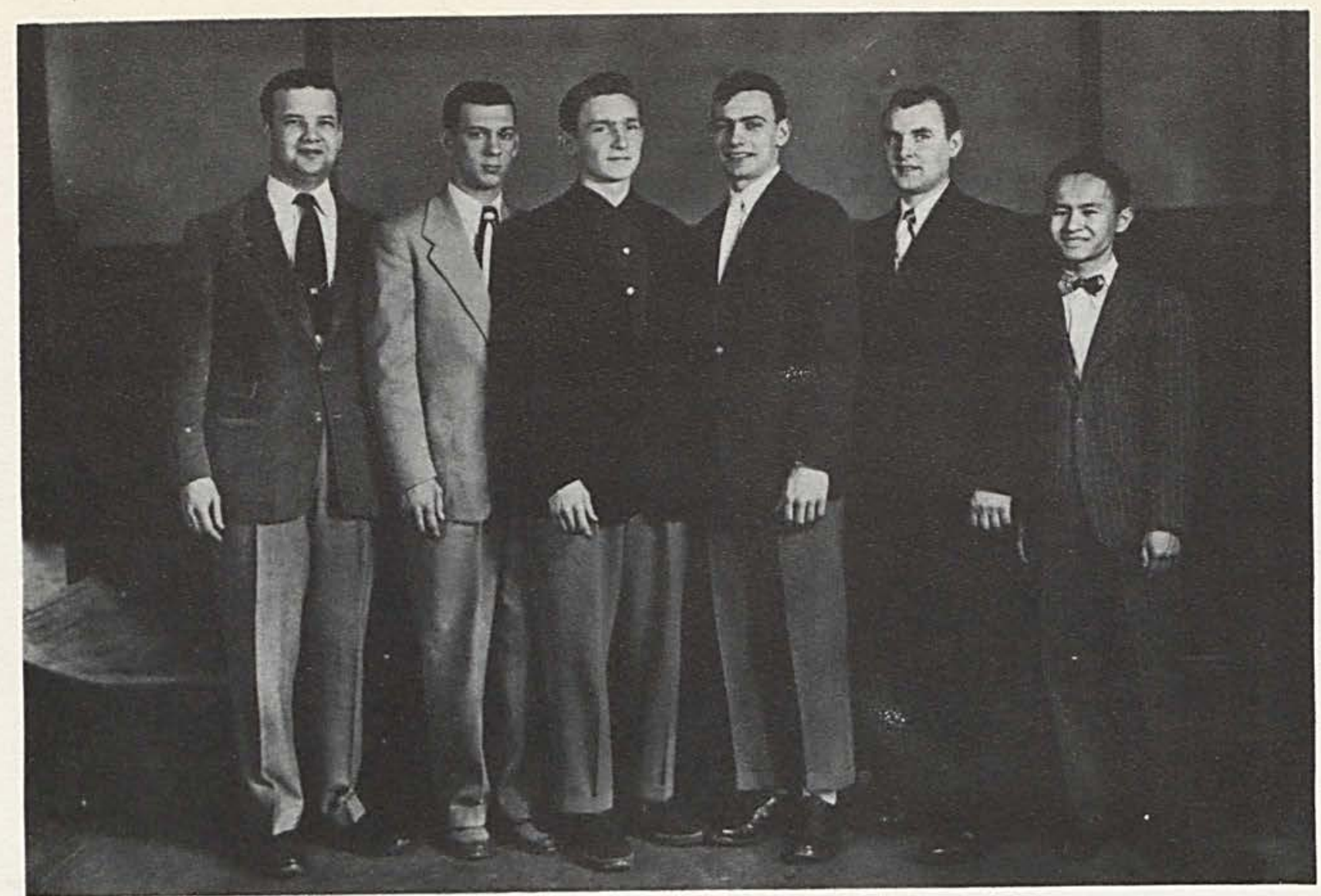

Left to right: William Albright, Dick Hatfield, Merlin Zell, Ted Sutton, Robert Miller, Harman Lum.

\section{Zeta Sigma}

One of the many chapters of the Zeta Sigma National Social Fraternity is located on the Cedarville campus. It is known as the Ohio Alpha Chapter of Zeta Sigma. This group pledged seventeen men but only five have qualified to become initiated into the Fraternity. Three out of the seventeen pledged are now in the United States Armed Servics.

The initiated members are Lutellis McCarty, Dick Martin. Bill Fife. Ted Sutton, and William Albright. The men qualified for initiation are Harman Lum, Robert Miller, Martin Yarnell, Clifford Dennis, and Dick Hatfield. The Pledges who still have a standard to meet are Homer Burton, Floyd Hopper, Merlyn Zell, Dave Farmer, and Robert Patrick.

Under the capable leadership of the following officers:

$\begin{array}{lr}\text { President } & \text { Ted Sutton } \\ \text { Vice-President } & \text { Bill Fife } \\ \text { Secretary-Treasurer } & \text { Harman Lum } \\ \text { Pledge Master } & \text { Dick Hatfield }\end{array}$

the Zeta Sigma Fraternity has and will continue to progress here at Cedarville. 

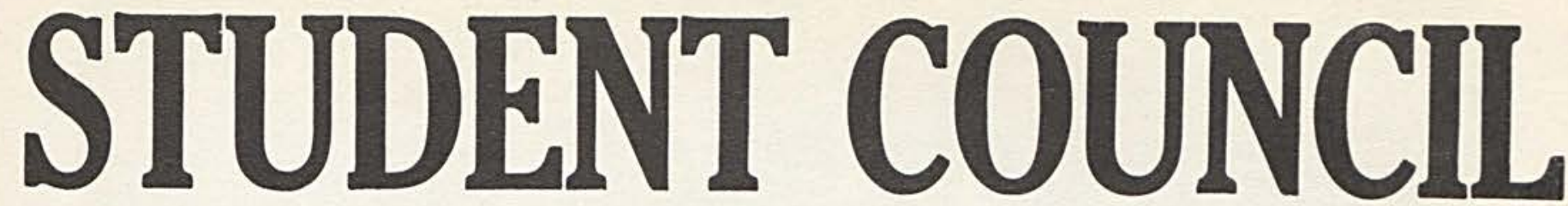

The student body met early last fall and elected the following people to the Student Council: President, Fred Long; Senior Representative, Wayne Stevens; Junior Representative, Paul Dunn; Sophomore Representative, Darrell Coe; and Freshman Representative, James Luttrell.

(The high-lights of the year's activities centered around homecoming with the governing body of the students in charge of the pre-game festivities. The council played an important role in placing the television set in the Co-op and worked very closely with the administration in stageing an all-school dance early in the spring. The officers wish to thank everyone that helped to make the above affairs a success.)

Left to right: James Luttrell, Darell Coe, Wayne Stevens, Fred Long, Paul Dunn.

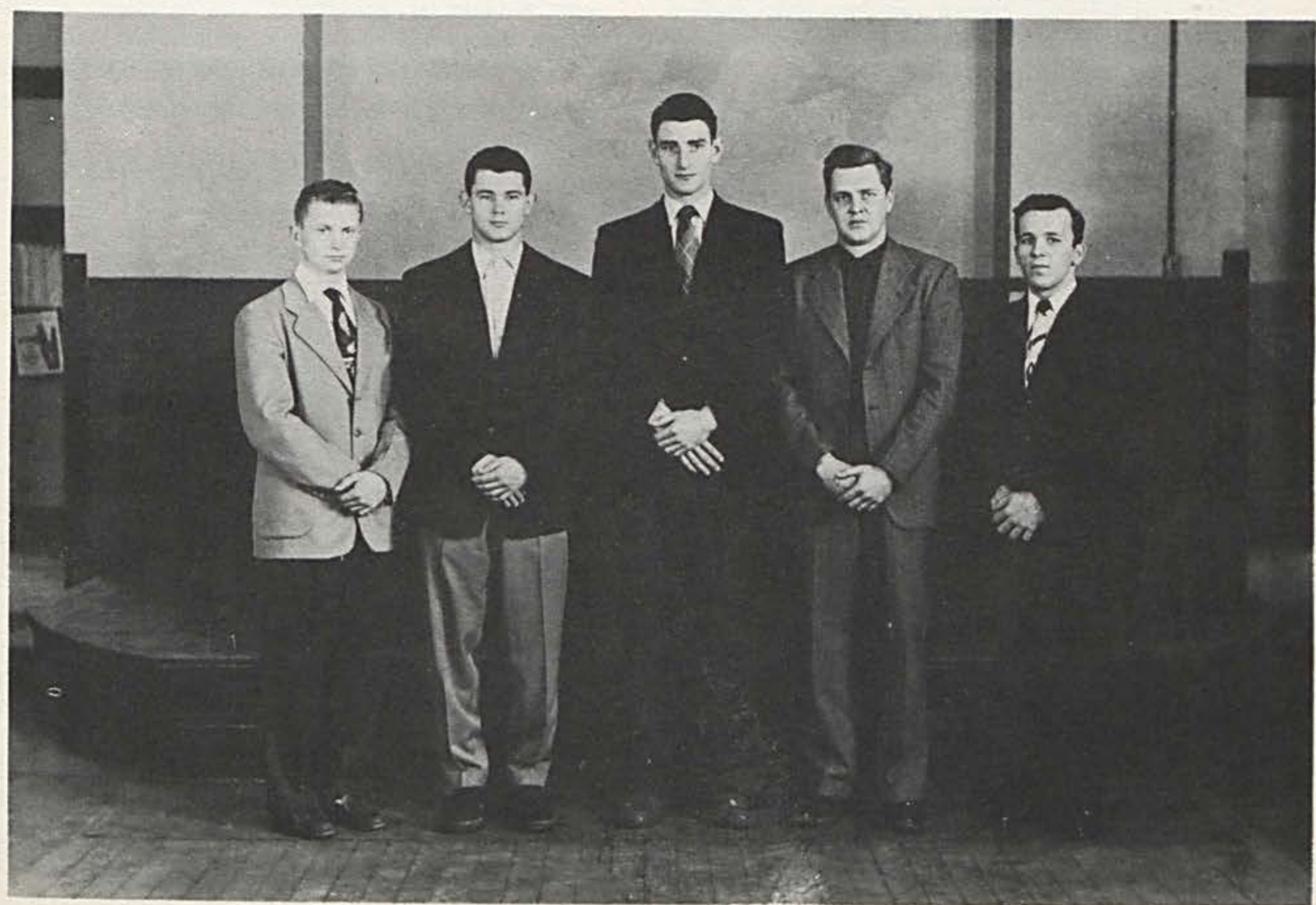




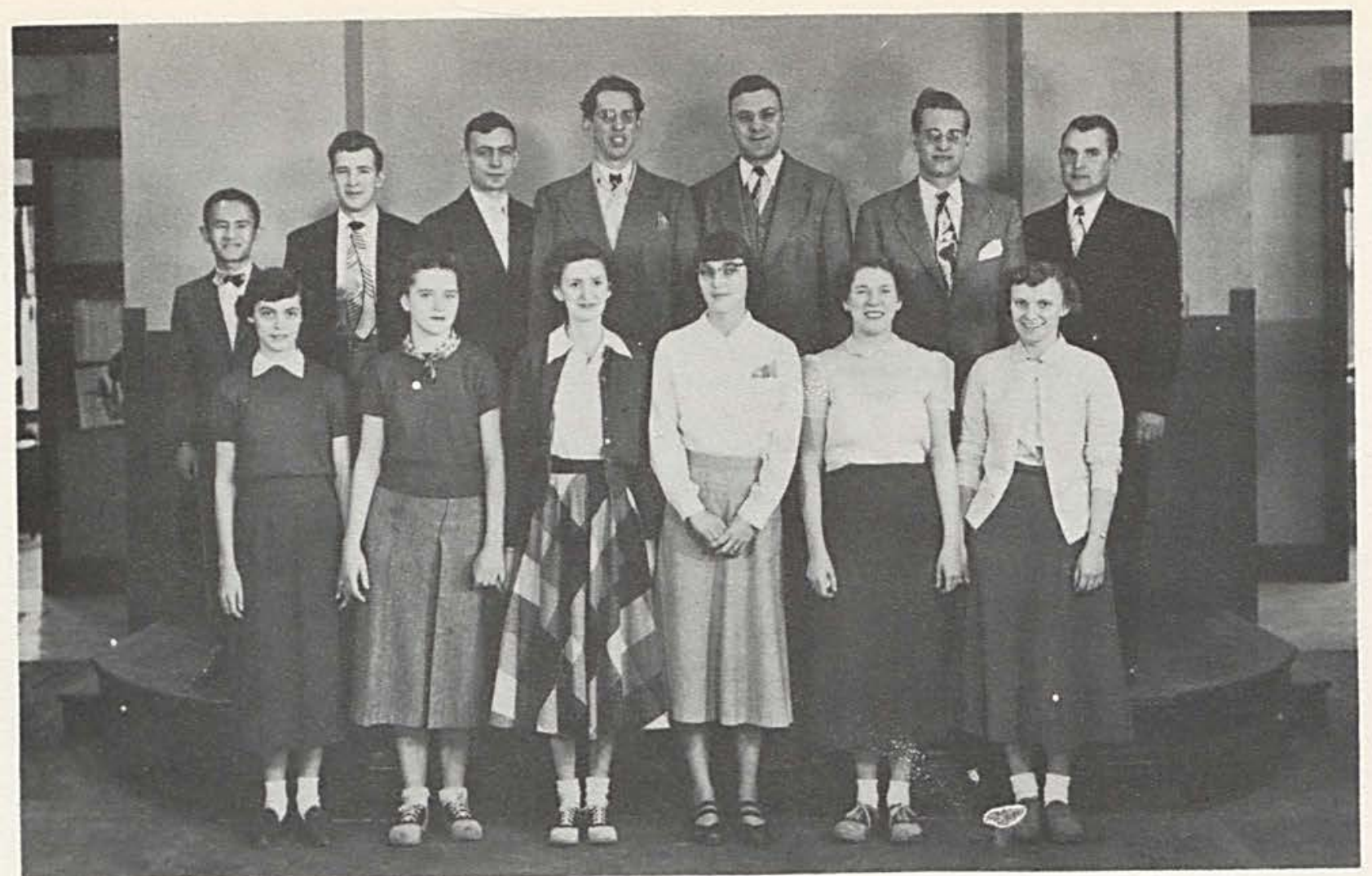

First Row, left to right: Margaret Swaney, Patricia Gossett, Ann Huffman, Mary Miller, Rebecca Creswell, Rosalind Miller. Second Row, left to right: Harman Lum, Jim Shaffer, Ted Sutton, Myers Bost, Frederick Carlsen (faculty advisor), Robert Hobbs, Robert Miller.

The Y. W. C. A. and the Y. M. C. A. of Cedarville College promote Christian leadership and Christian fellowship on the college campus. The two associations have met together during the past year, and everyone is invited to belong to this united organization.

av Meetings have been held on Thursday nights in the Recreation Hall, in charge of different members of the organization, the young men and women of the group presiding over the devotions on alternate weeks; thus everyone has an opportunity to develop leadership.

The organization sponsored a party (movies and refreshments) last fall for the student body.

(The Y. W. C. A.-Y. M. C. A. of Cedarville College, Antioch College, Wilberforce State College, and Wilmington College presented a variety show at the Xenia Central High School auditorium on Thursday, March 15, to promote fellowship among the four colleges and to raise money for the World Student Service Fund.)

Officers are: Myers Bost, Acting Chairman; Ted Sutton, Secretary-Treasurer; Rev. and Mrs. Frederic Carlsen, faculty advisors.

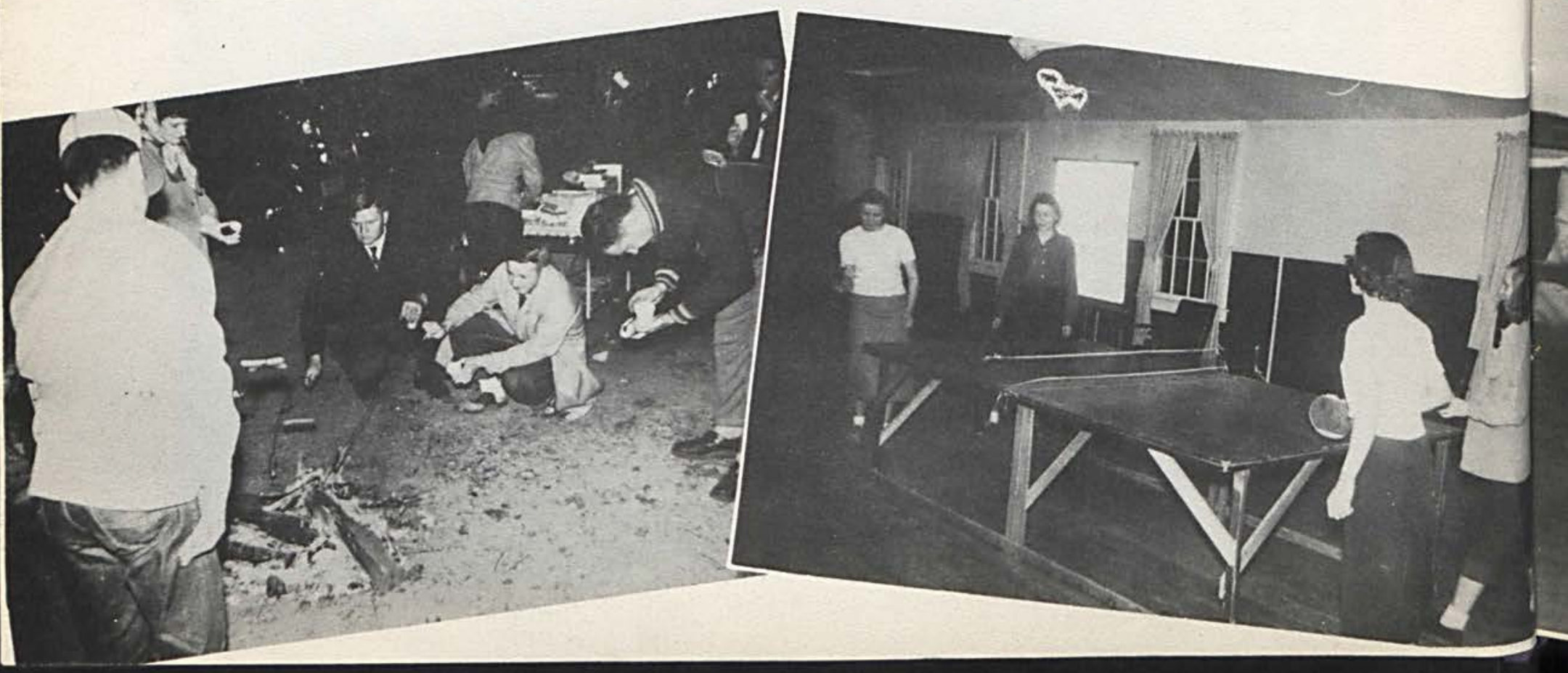




\section{(II) IIt ter}

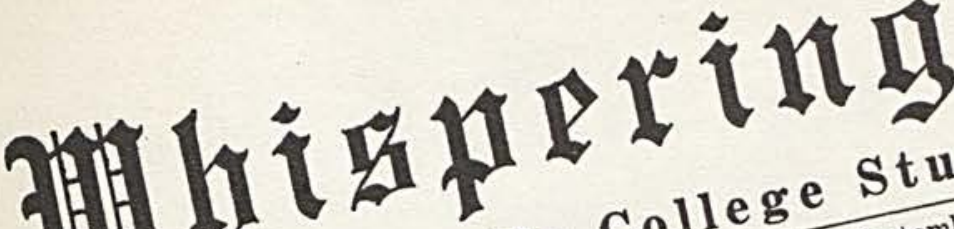

Cedarville Colle ge september 25 ,

voumo ill Resigns; Replaced Vayhinger Resign Springfield

Vayhinger Resigns,
By E. H. Miller Of Springfield
Several Changes In College Staff

Dr. Ira D. Vayhi ted his resignation of trustees, of close lege at the August school in Alive tion, eflectived by was acception of the positiont mains vadent vice-president H manager president.

Dr. and Mrs. Vayhinger where moved to Fletoler, Presbyterian he is pastor af ther had come business

Seated, left to right: Nancy Guilfoyle, Frank Zirble, Wayne Stevens, Imogene Schrivner, Jack Bellville. Standing, left to right: Jim Shaffer, Howard Wise, Paul Dunn.
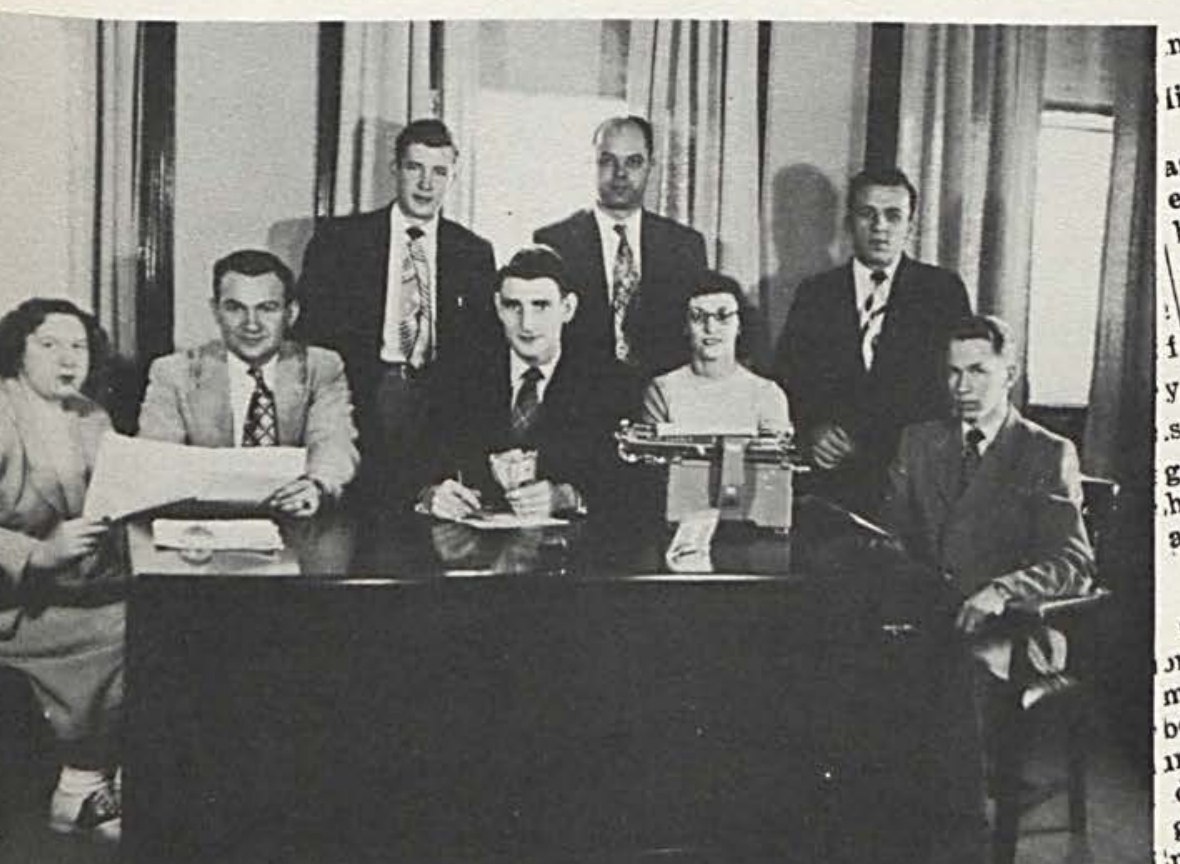

The "Whispering Cedars" is Cedarville College's newspaper. It is published every two weeks, in the interest of the college, it's student body, alumni, and friends. in the paper has made great strides in bringing to its many readers a steady flow of news and features as they happened tactful manner.

We sincerely thank Professor Howard Wise for his keen interest, many hours of service, and suggestions in the printing of each issue.

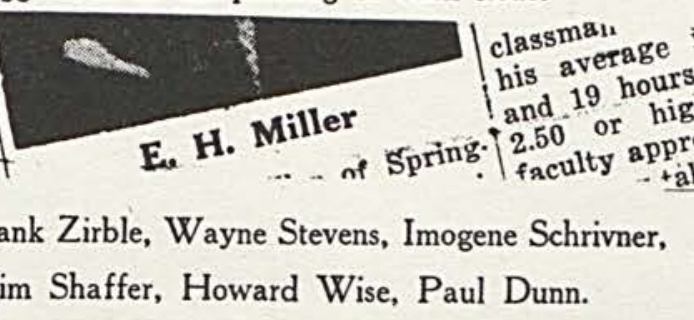




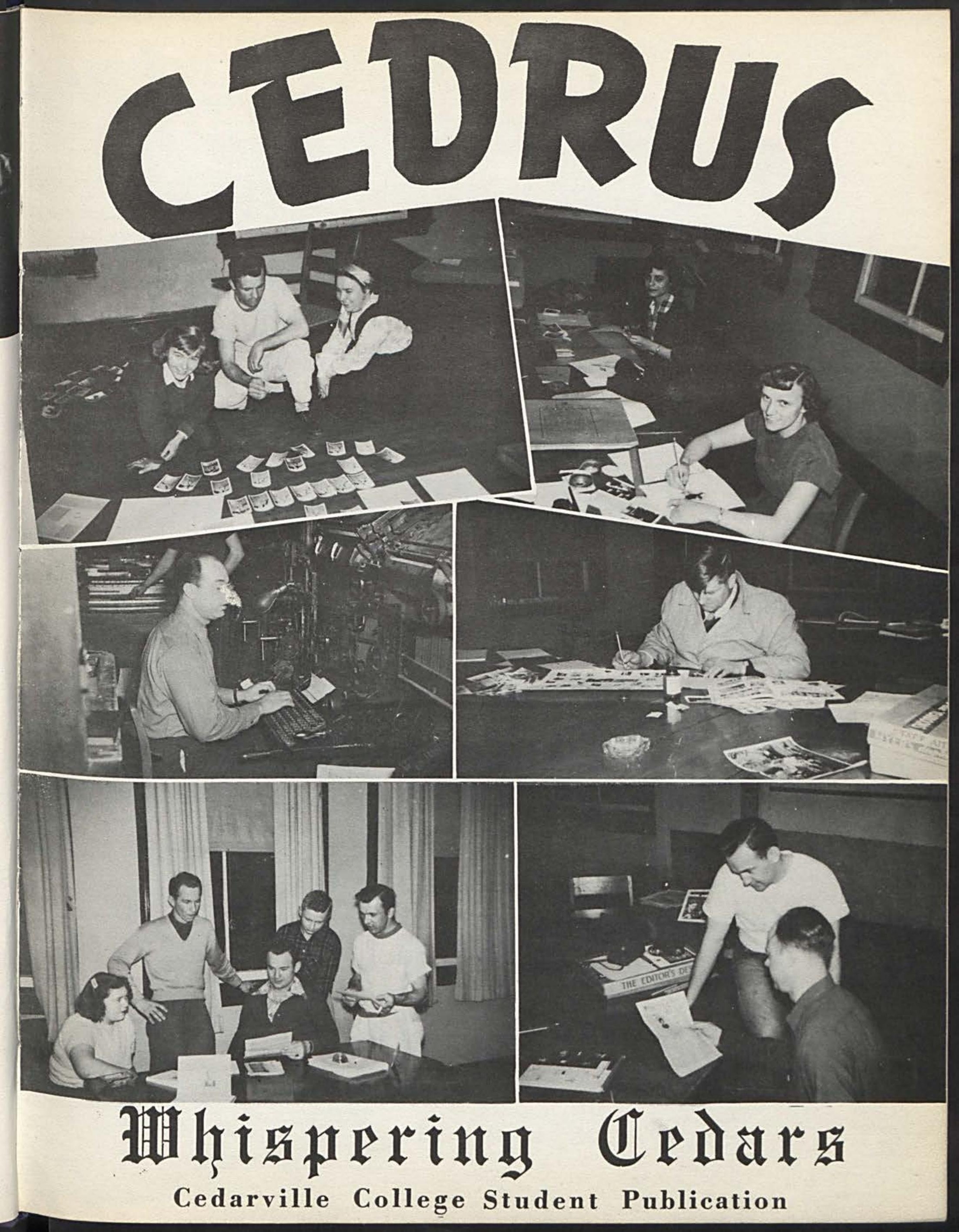




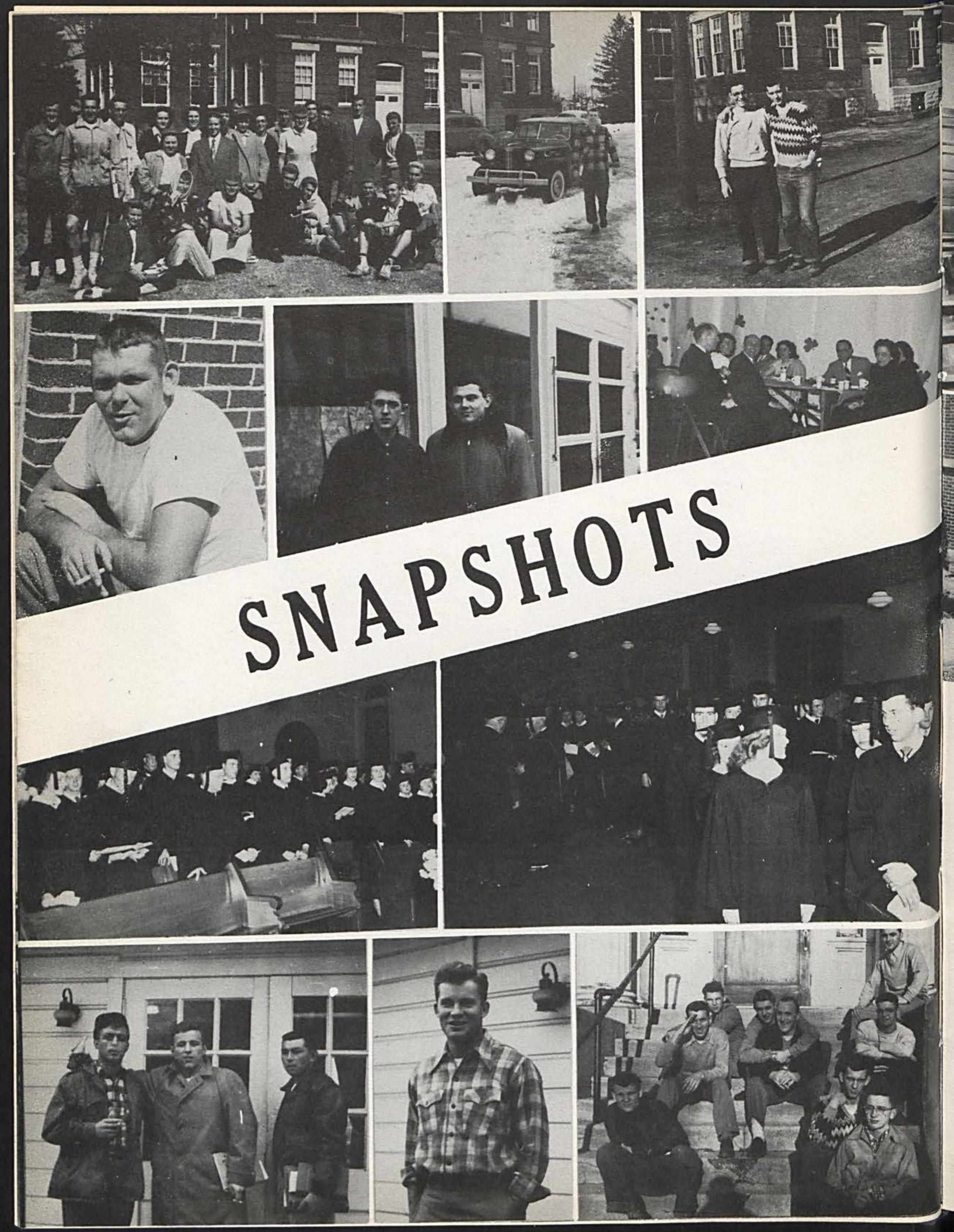




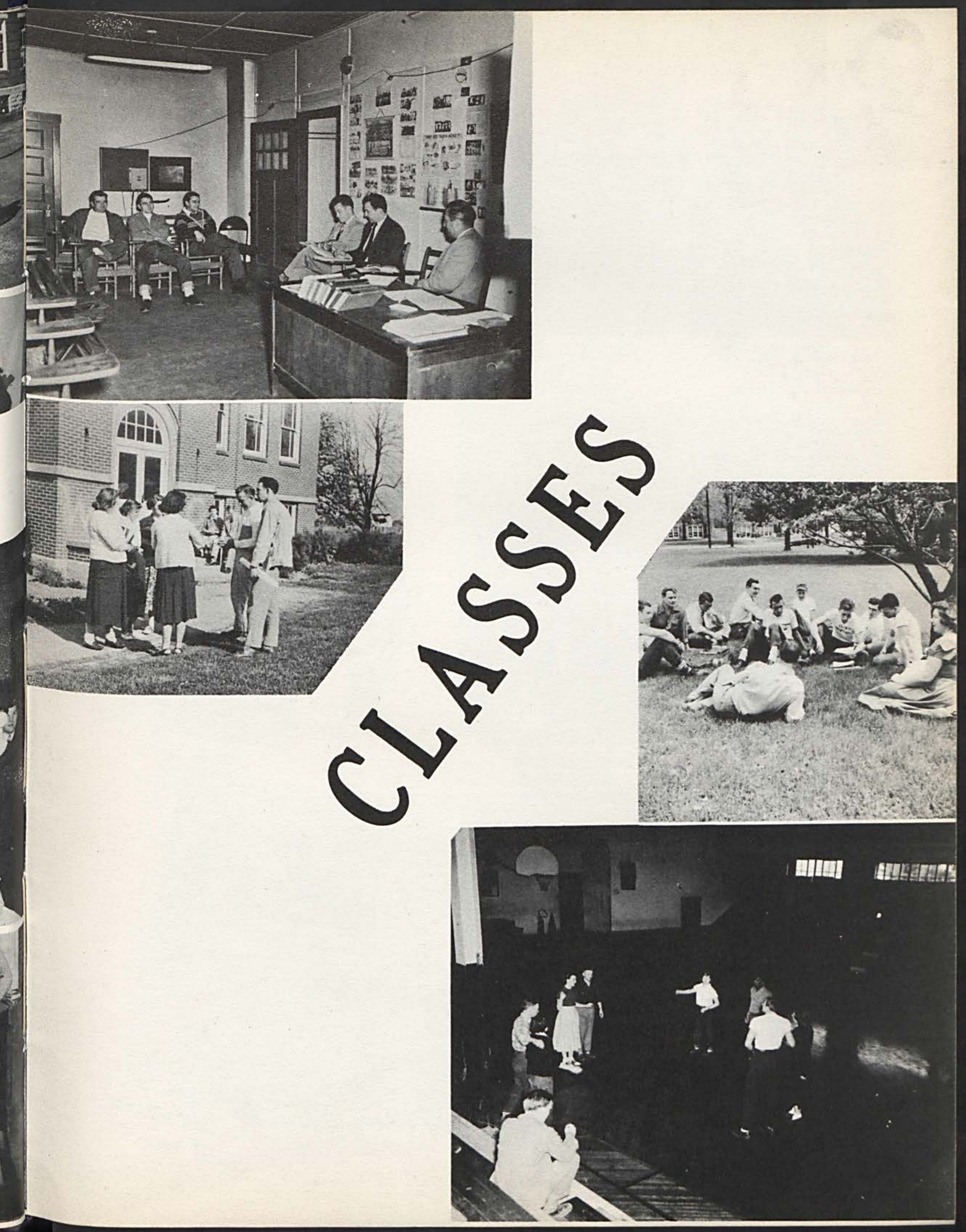




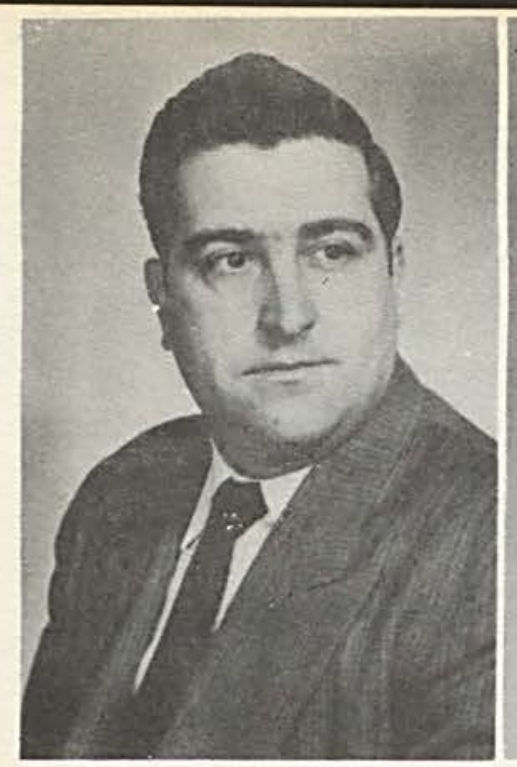

EUGENE FISHER

Waterb ury. Vermont

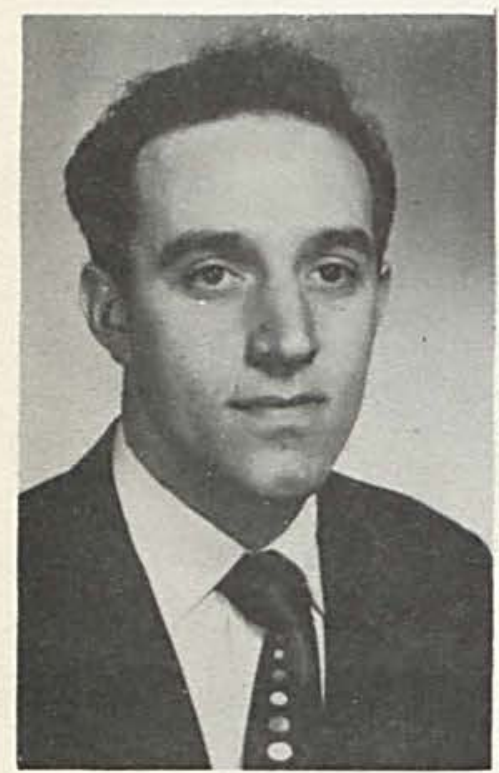

GENE CULTICE Dual Curriculum

Troy, Ohio

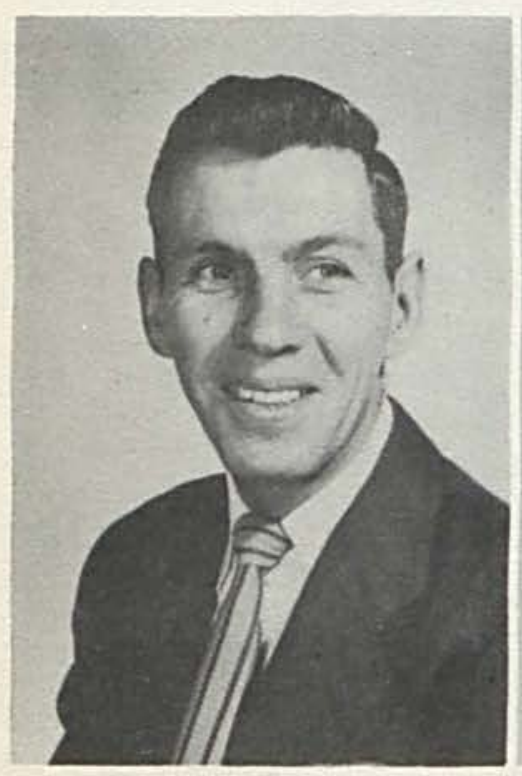

EMERSON ACKISON

B.S. in Ed.

Xenia, Ohio

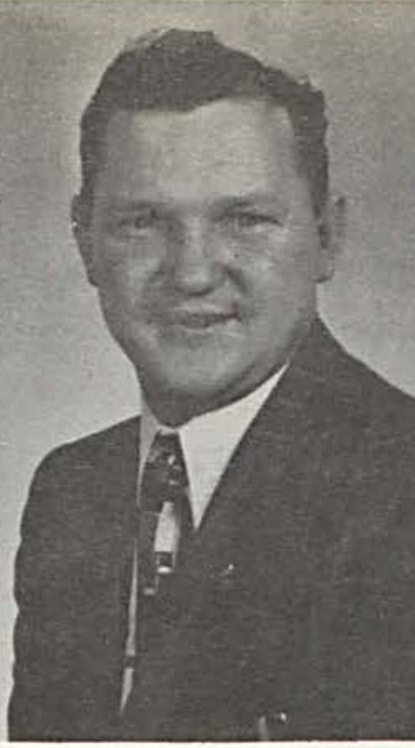

PAUL KLONTZ B.S. in Ed. Jamestown, Ohio

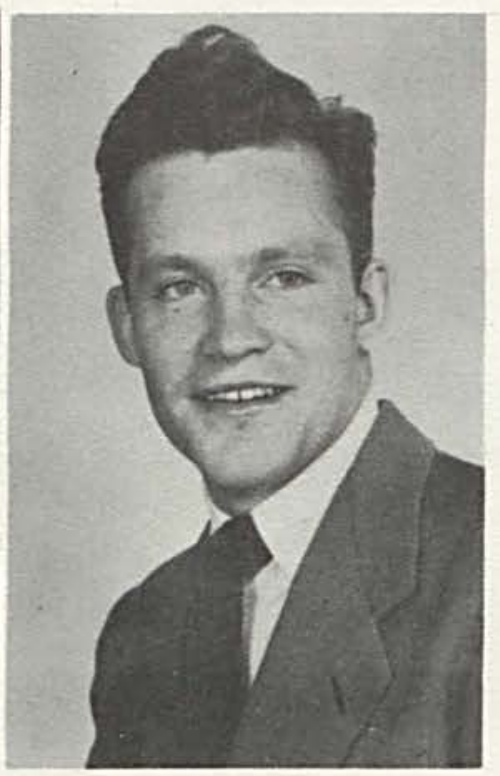

GARLAND COX

B.S. in Ed.

Manchester, Ohio

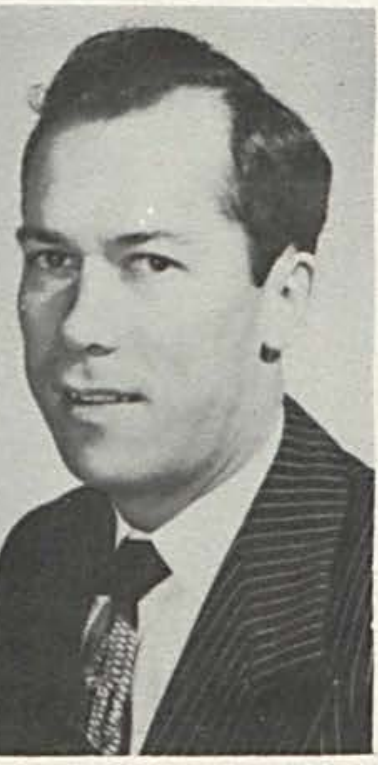

RAY CARTER

B.S. in Ed.

Gallia, Ohio
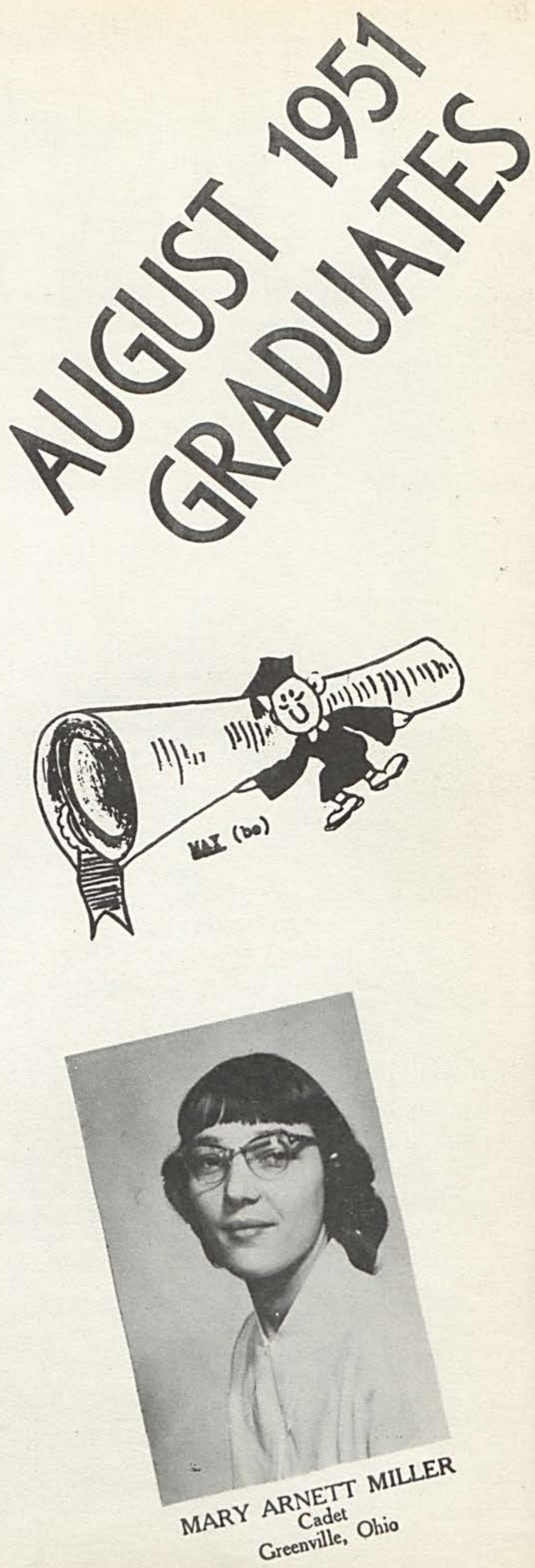


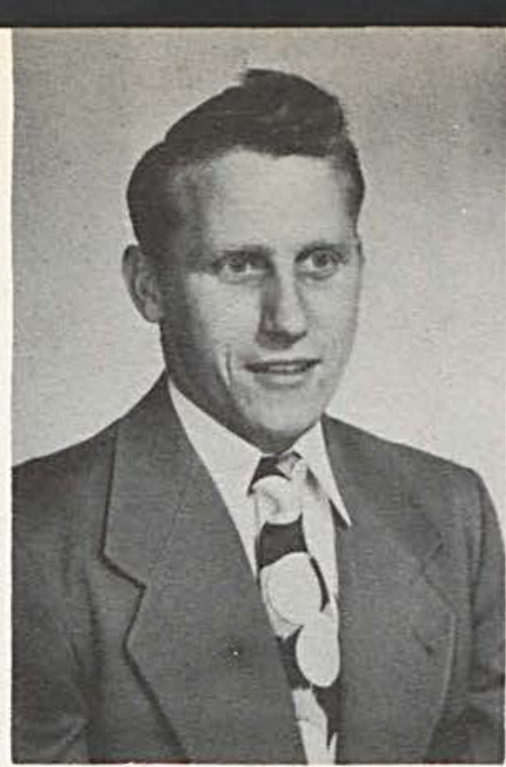

THOMAS OSBORNE

B.S in Ed.

South Point, Ohio
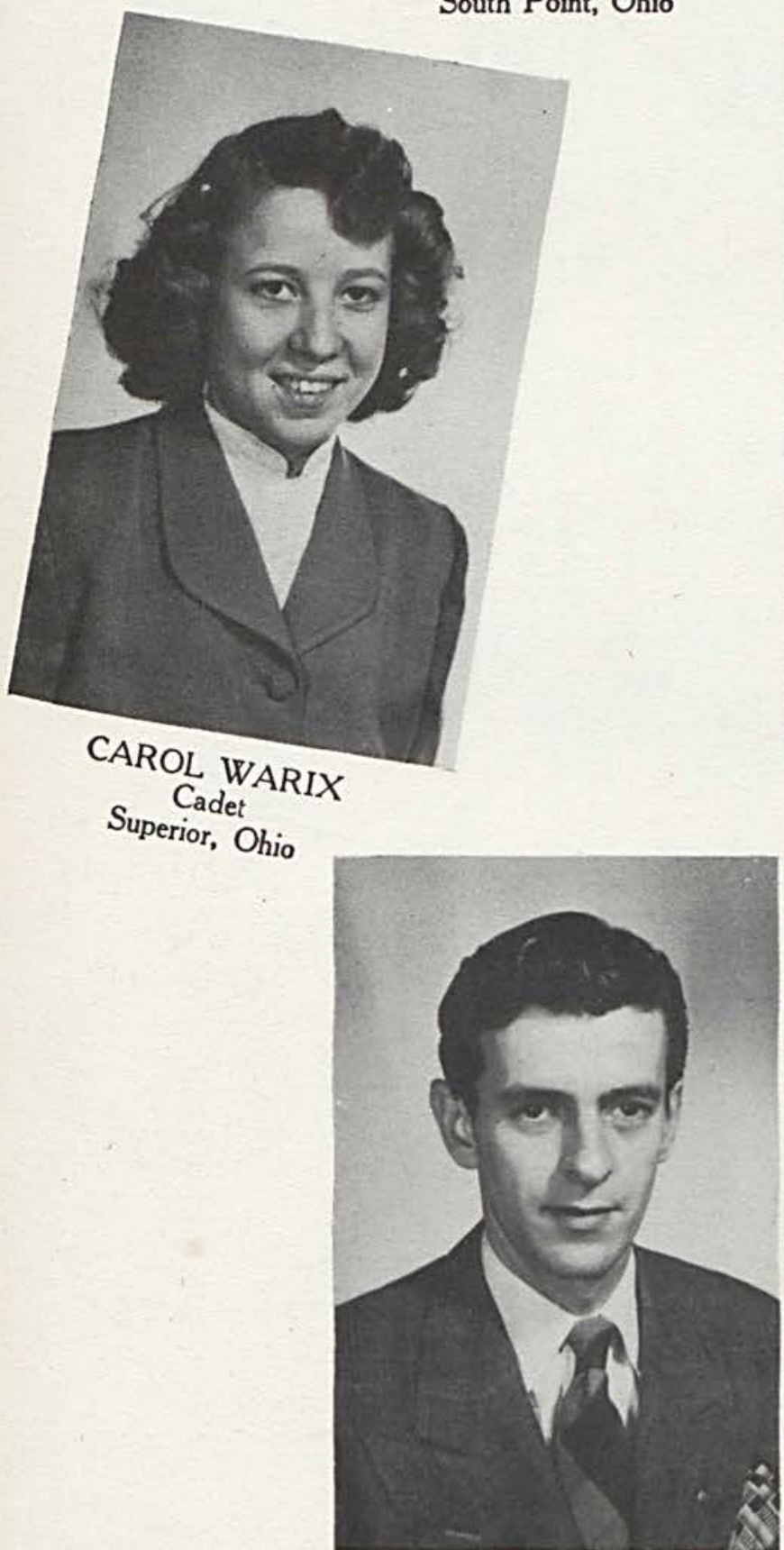

RICHARD WRIGHT

B.S. in Ed.

Cedarville, Ohio

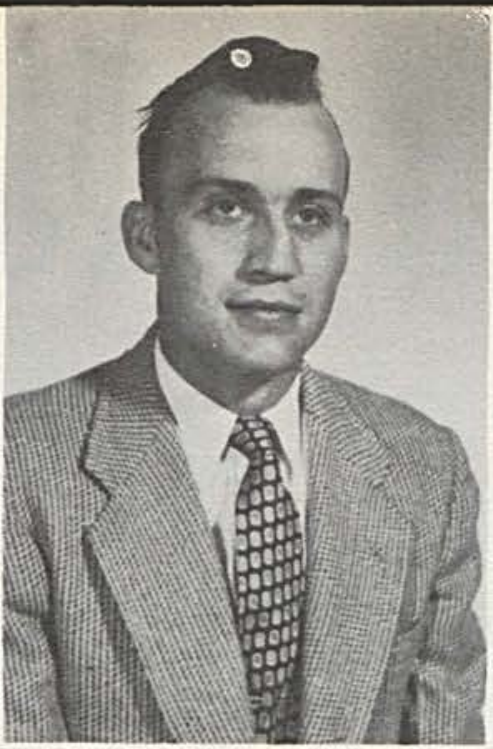

FRANK PICKENS

B.S. in Ed.

Jamestown. Ohio

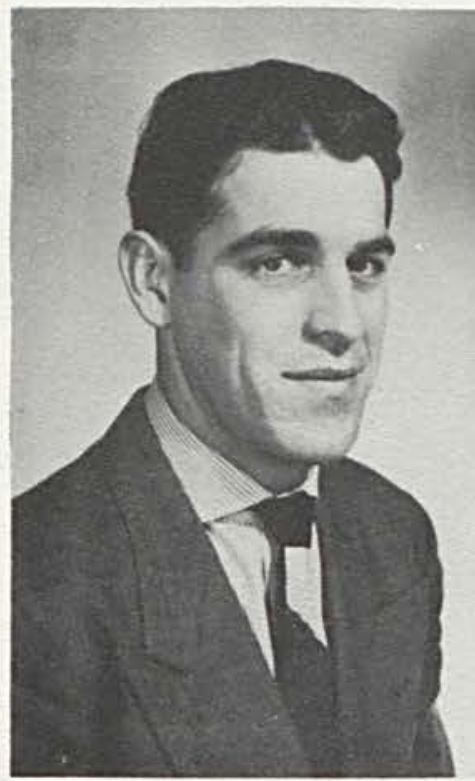

ROBERT PETERS

B.S. in Ed.

Fairborn, Ohio

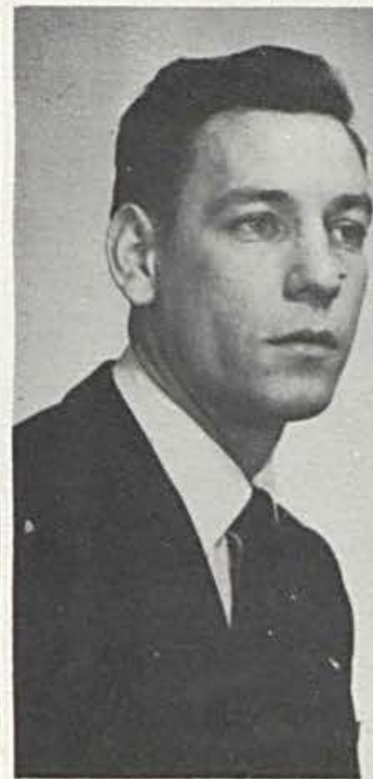

ALSON SCRIVNER

B.S. in Ed.

Hamilton, Ohio

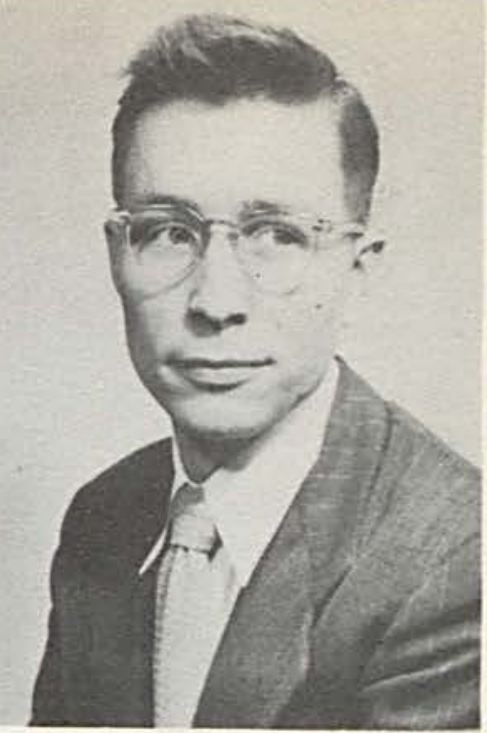

RICHARD SMITH

B.S. in Ed.

Xenia, Ohio

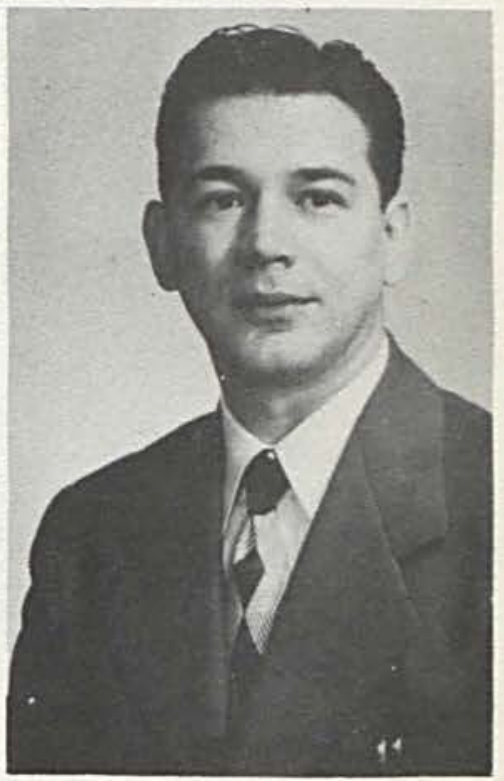

WALTER SEWAK

Dual Curriculum

Johnstown, $\mathrm{Pa}$.

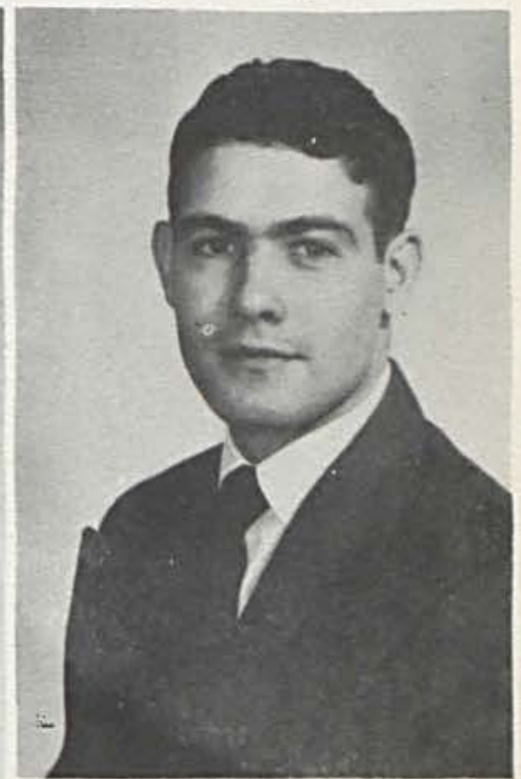

GLEN SHUMATE B.S. in Ed.

South Webster, Ohio 


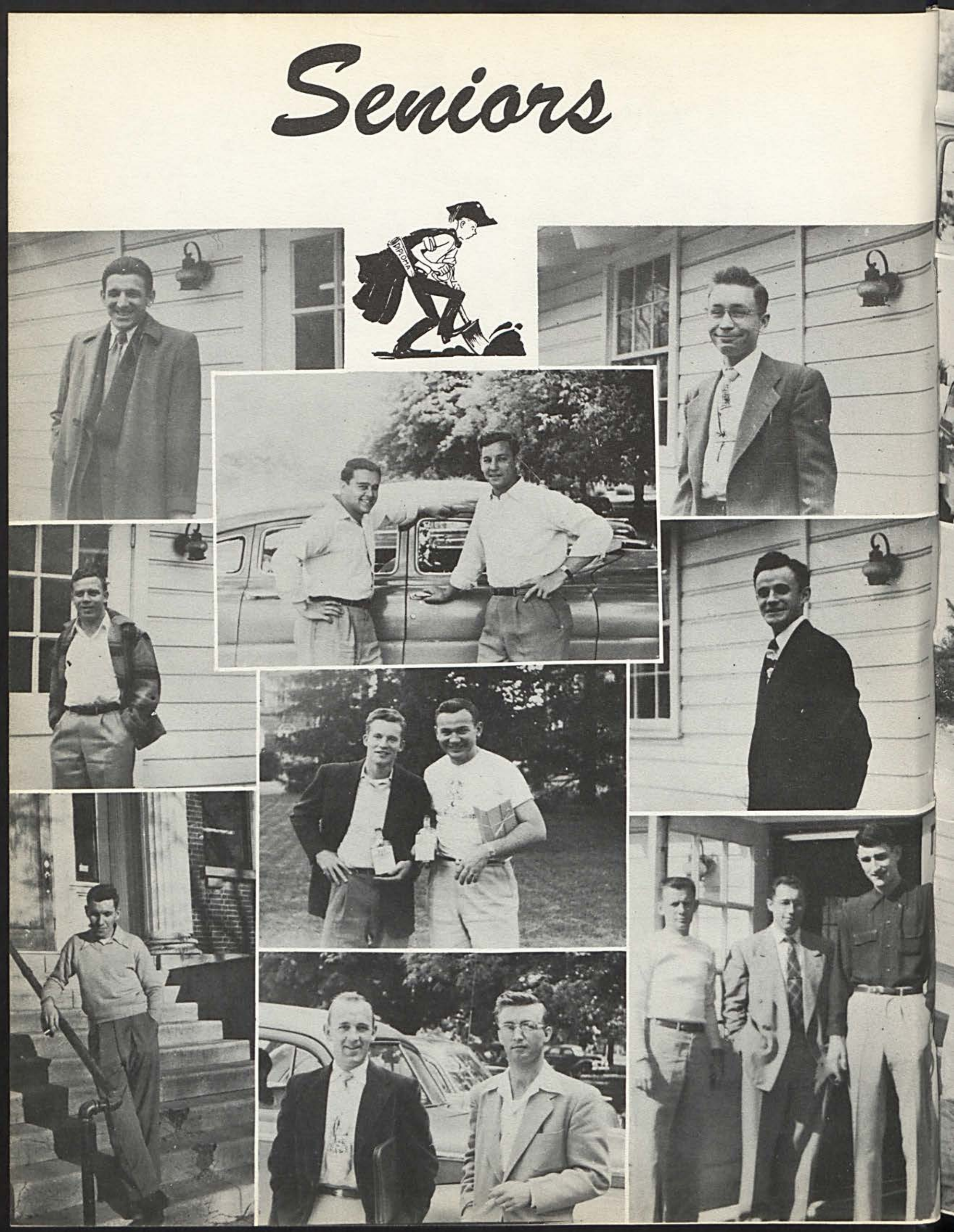




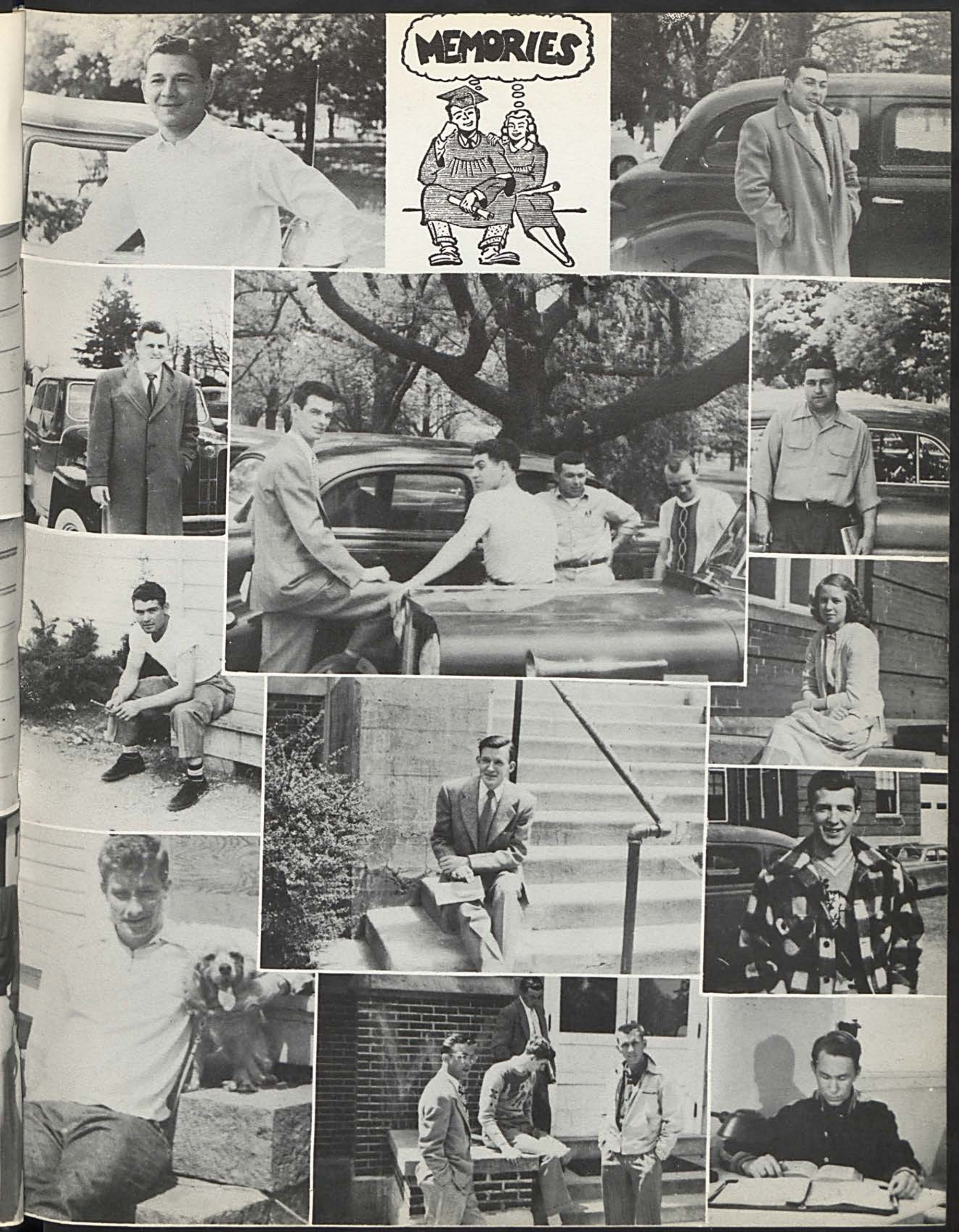




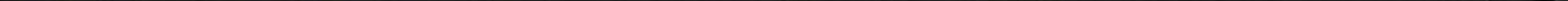




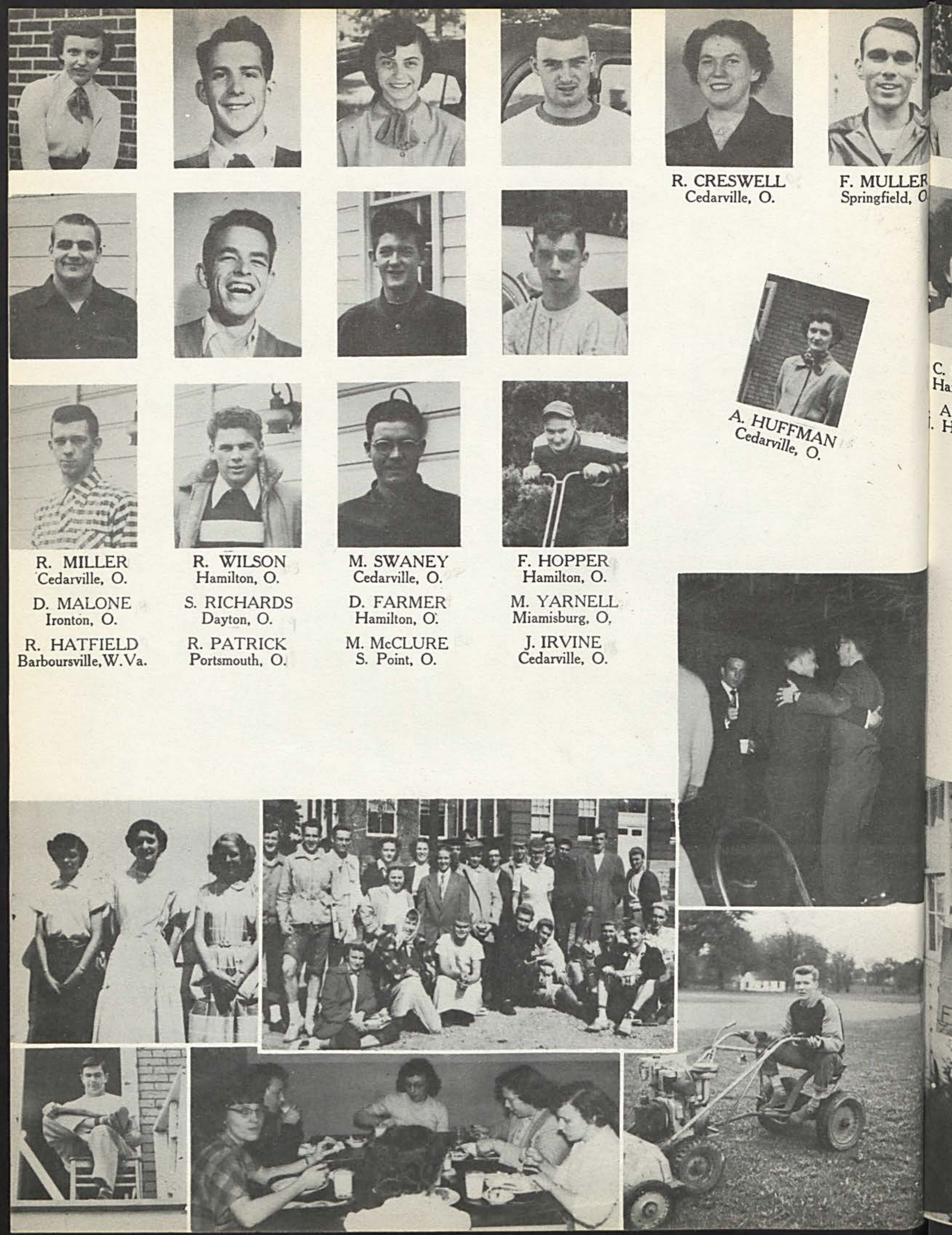




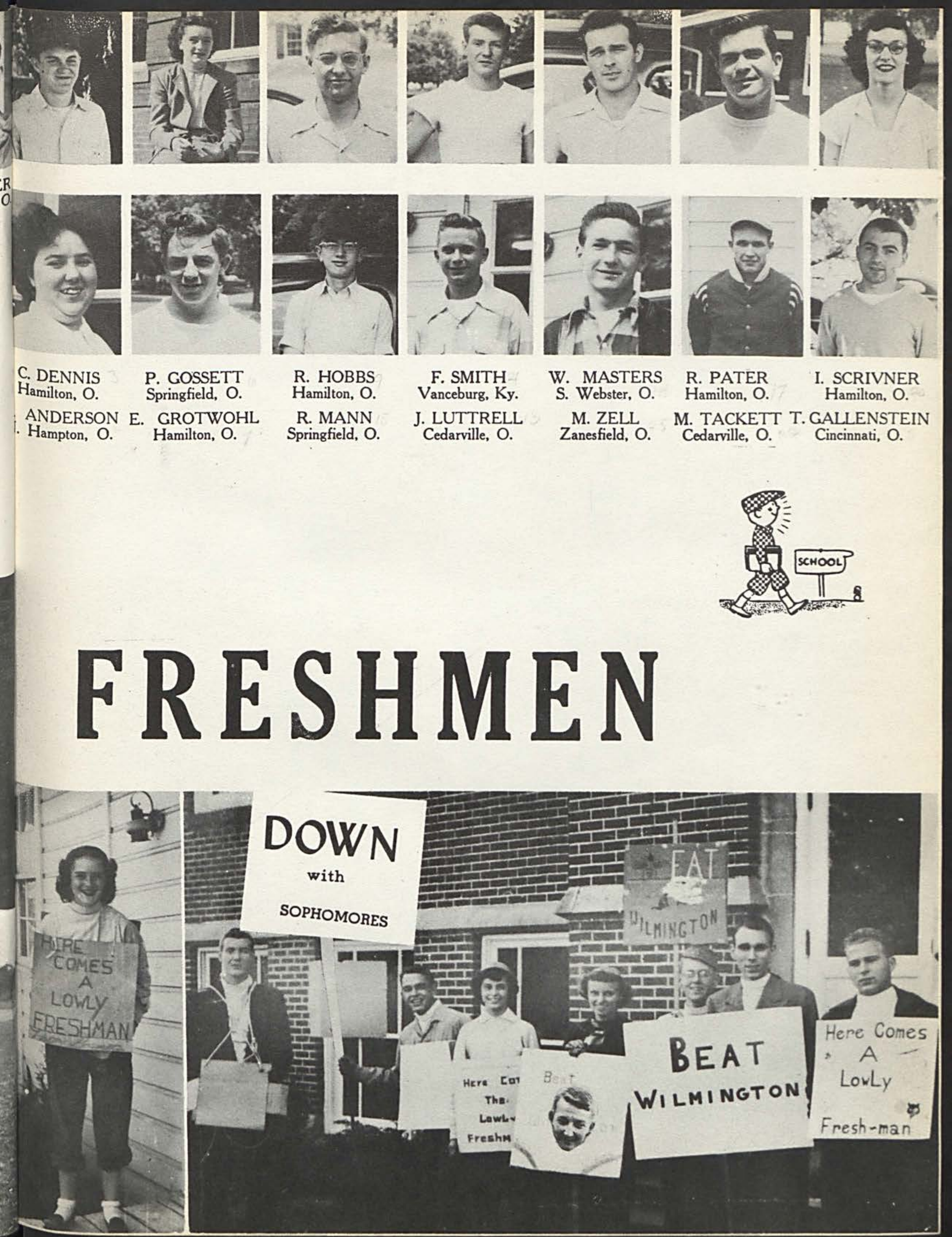




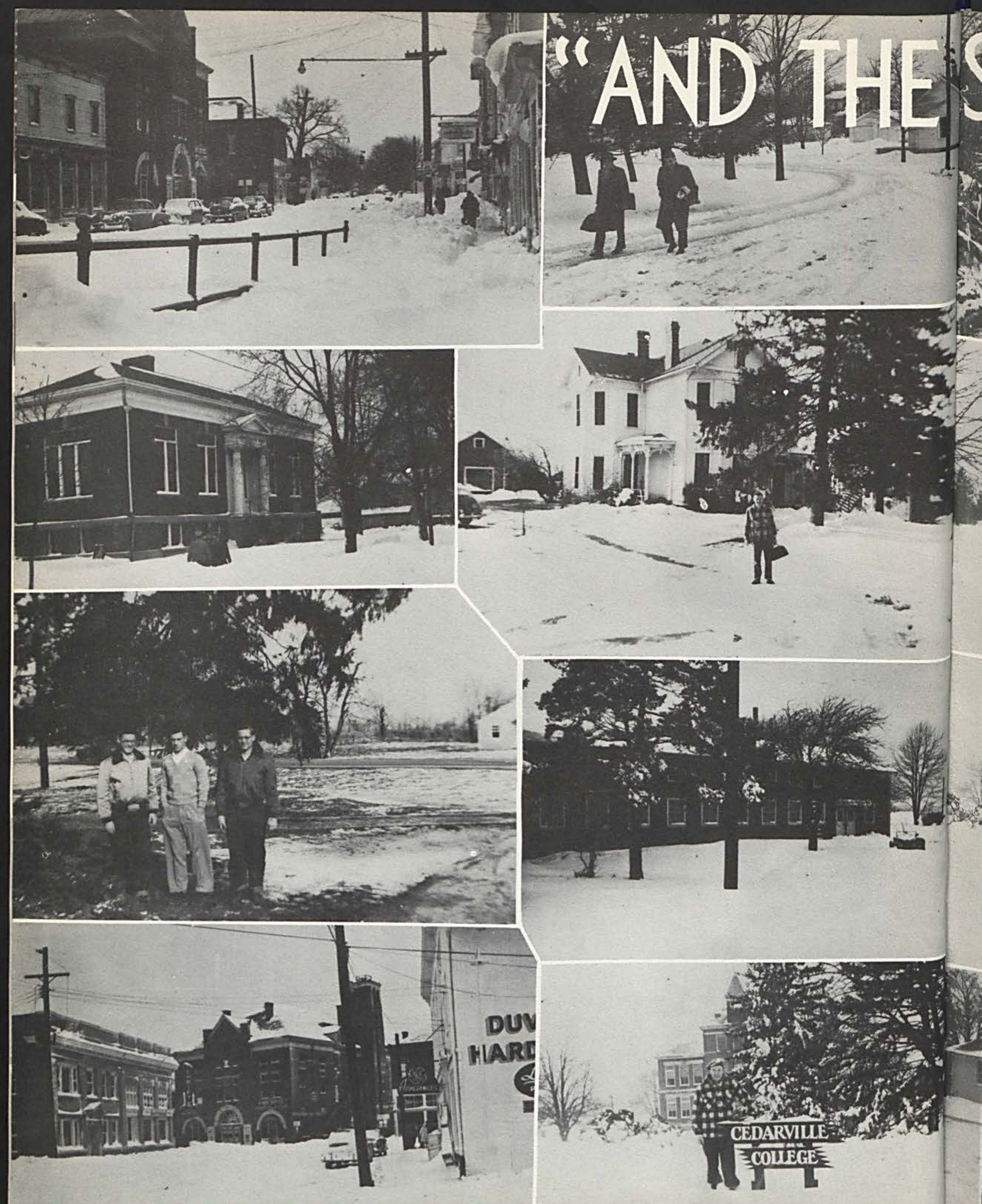




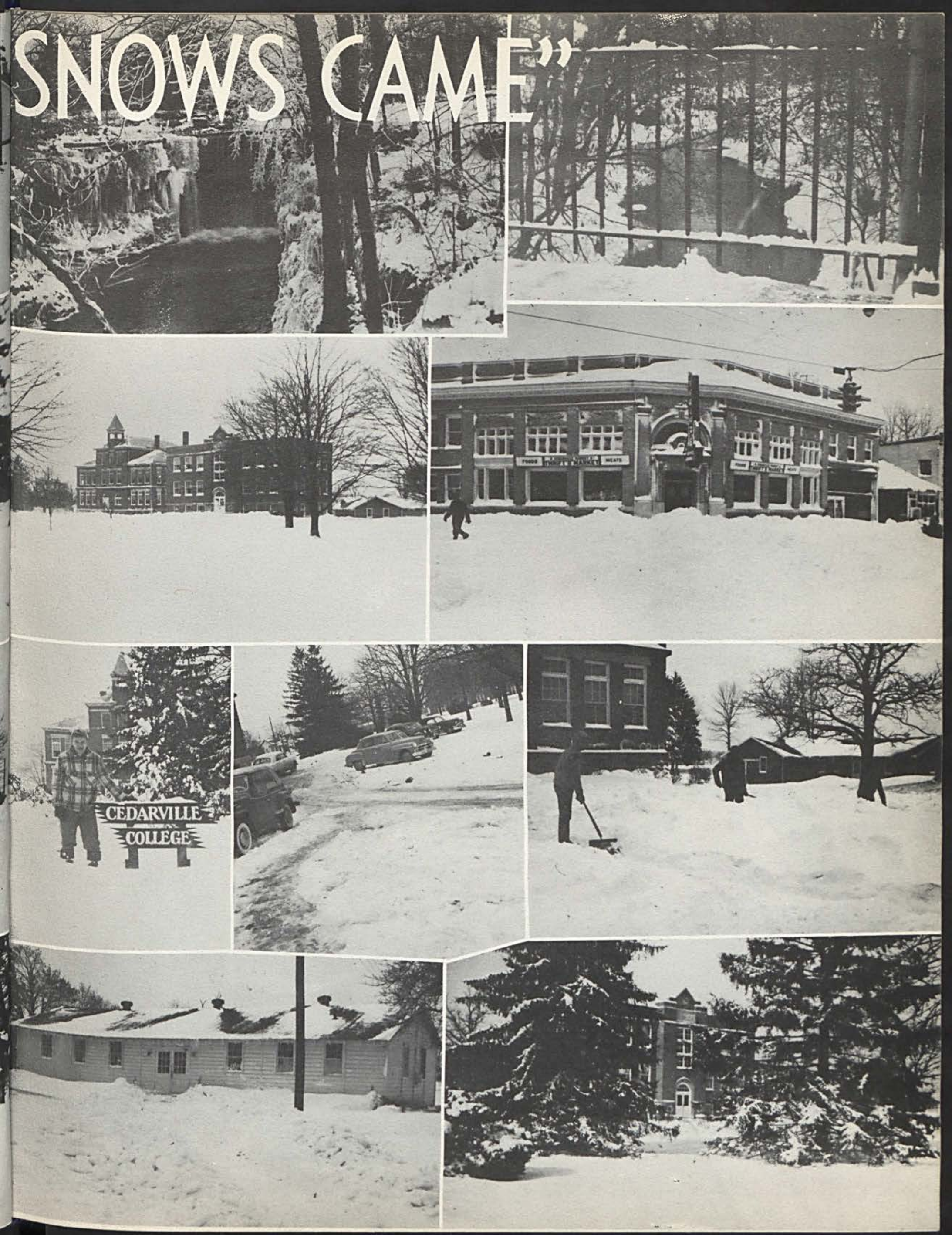




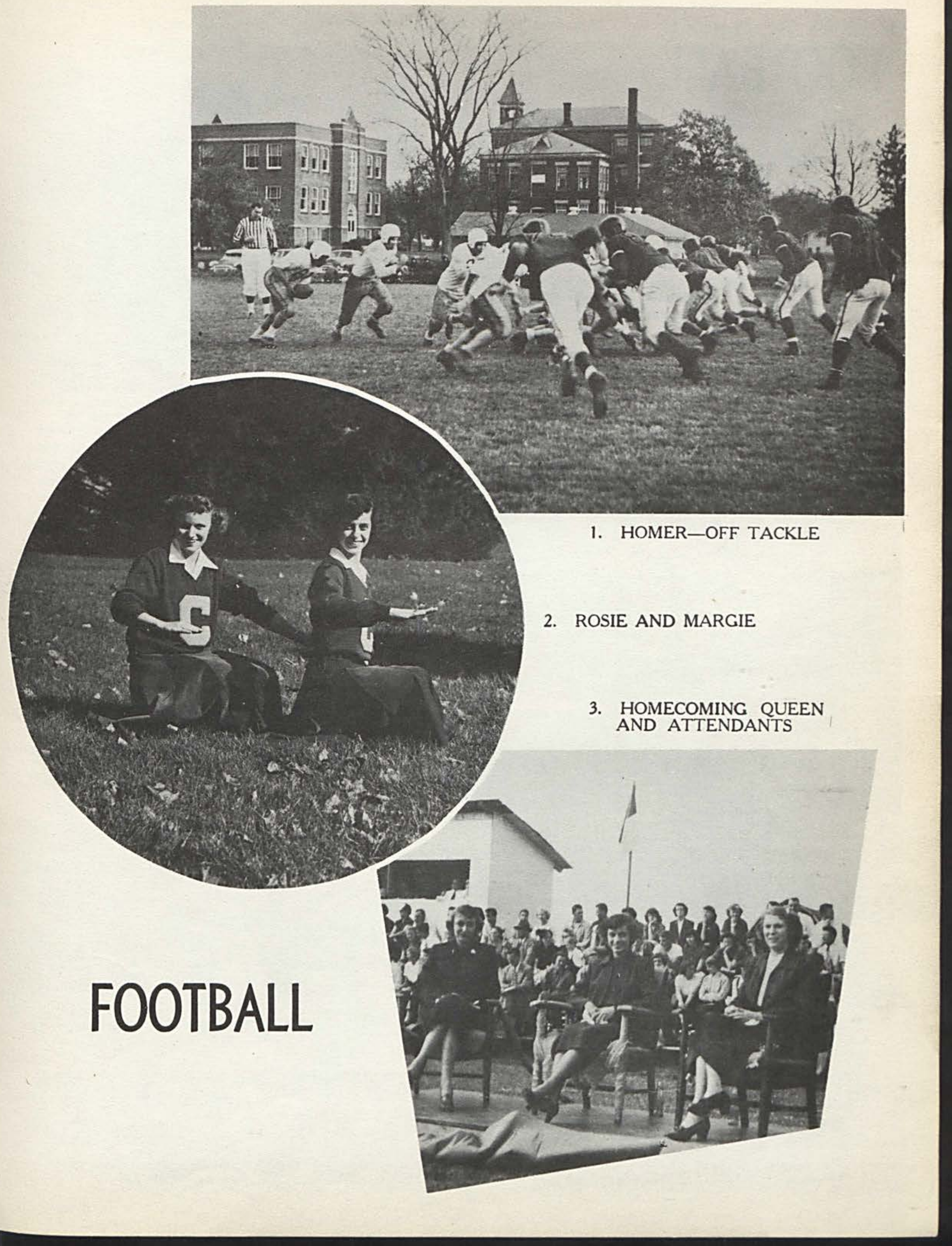




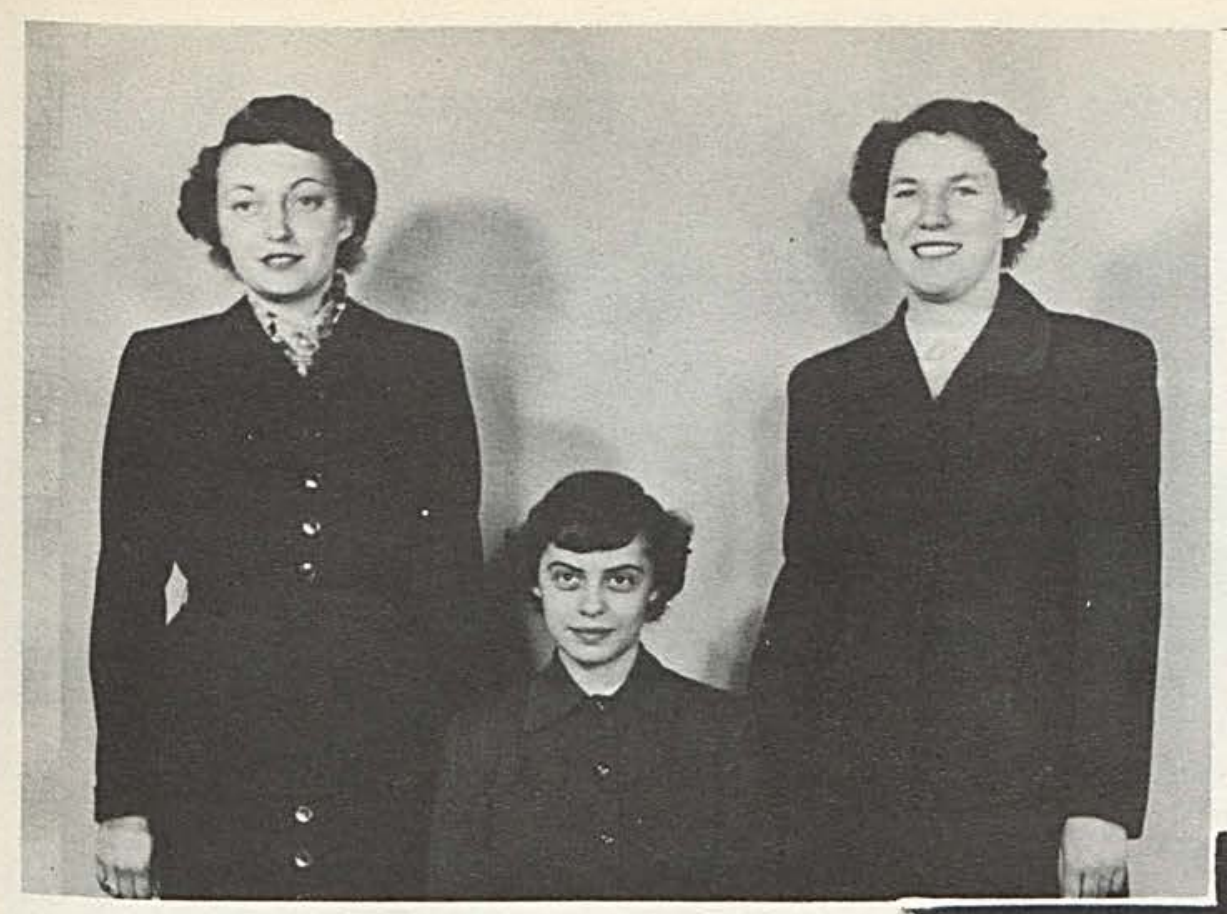

A quirk in the Cedarville football schedule caused the annual football homecoming to be held unusually early this year. Since all the October games were to be played away from home, the homecoming day had to be set for September 30, thus avoiding the cold November weather.

The Homecoming Day activities began with a parade up Main Street, led by the Cedarville High School band. The crux of the parade consisted of floats, built by the fraternities, and a convertible in which the queen, Margaret Swaney, and her two attendants, Mary French and Rebecca Creswell, rode. The parade ended in a flourish at the football field, where the queen was presented with a spray of flowers by the co-captains of the football team, James Wagner and Homer Burton.

The opposition for the homecoming football game was furnished by Ashland College, and opposition it was, as the Yellow Jackets came out on the short end of the 28-19 score.

The alumni banquet followed, at which Mr. Miller, Acting President of the College, spoke to the alumni.

In the evening, the Homecoming dance was held in the High School auditorium, brightly decorated by the Student Council. It was here that the homecoming activities, for the 1950 football season, came to an end.

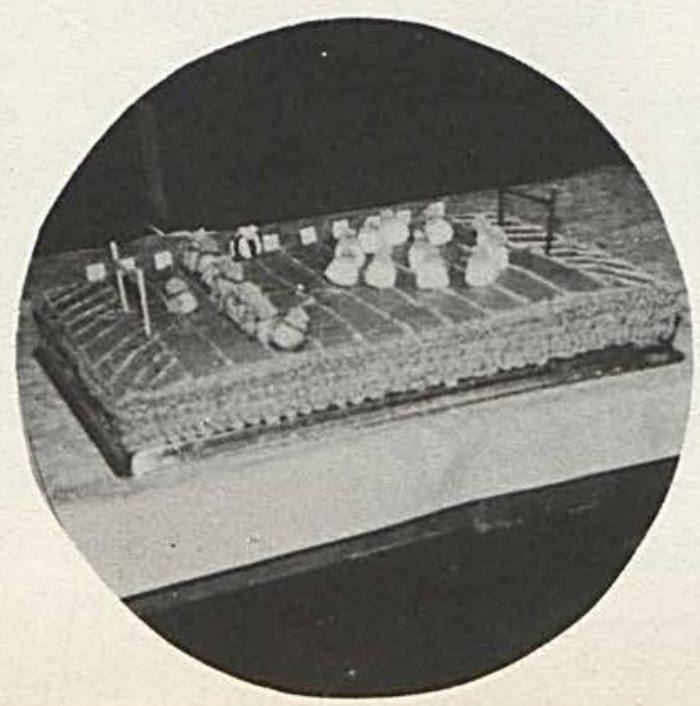

\section{HOMECOMING}
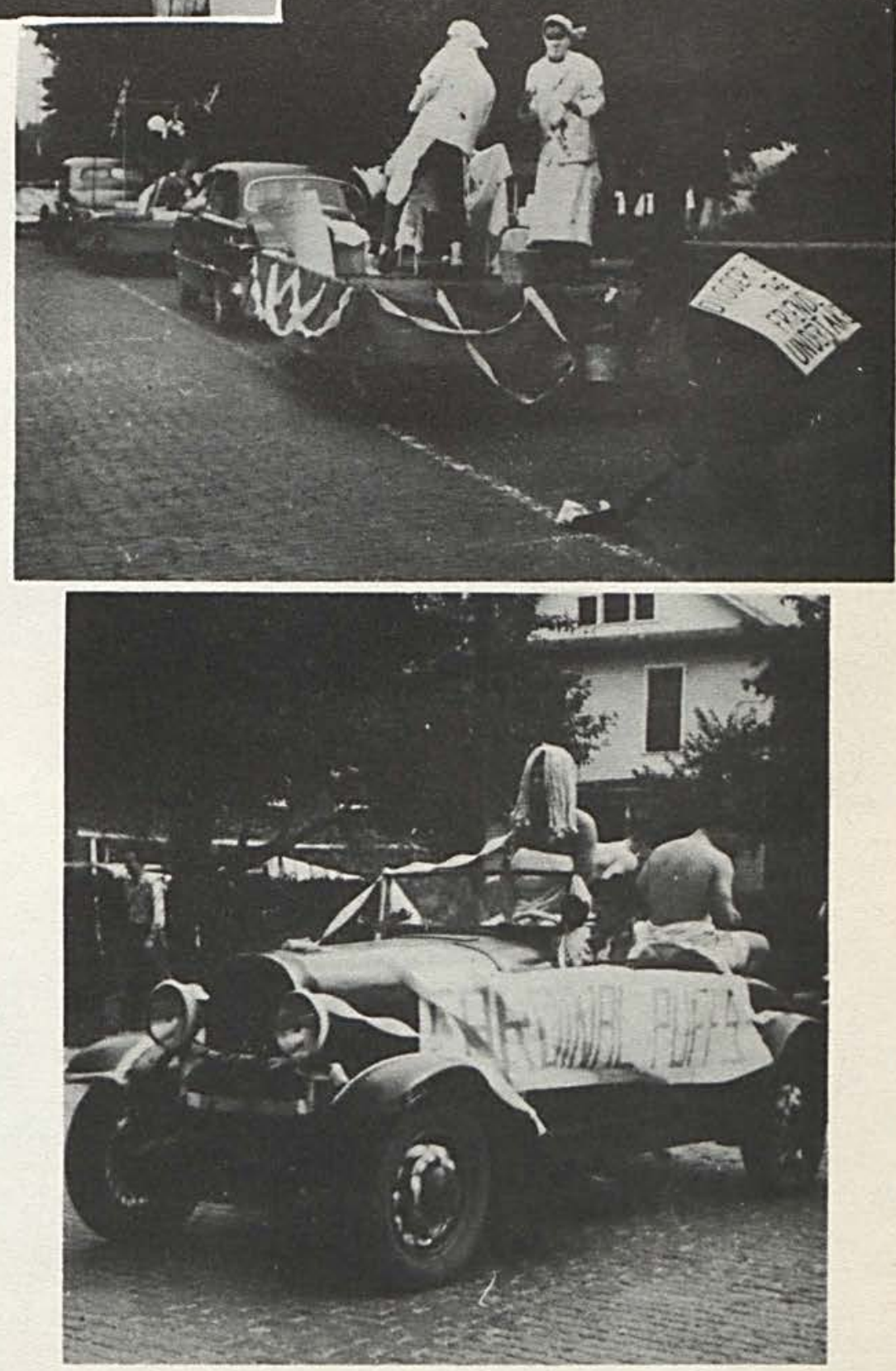


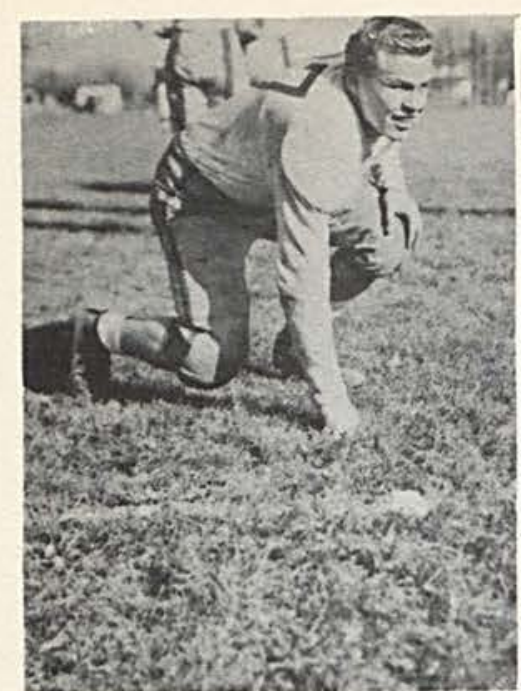

1. J. WAGNER

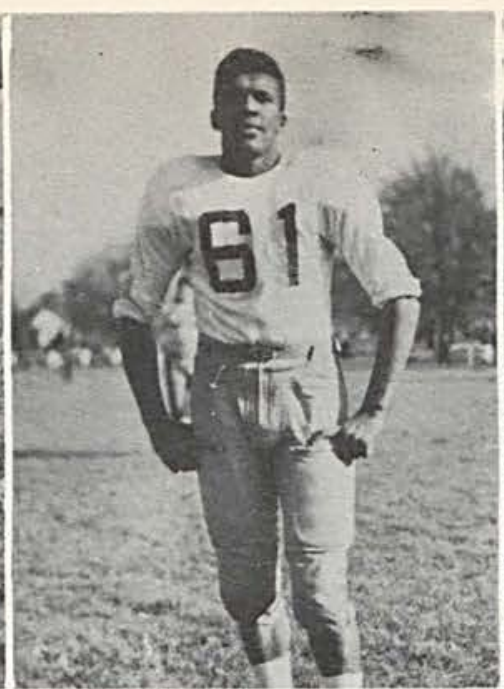

2. H. BURTON Halfback

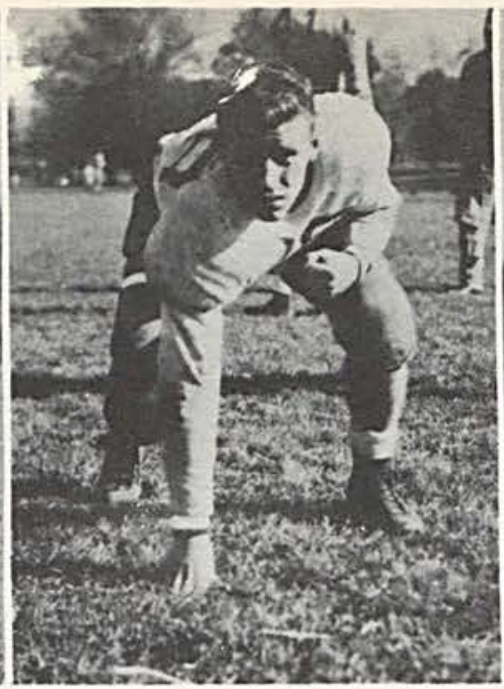

3. K. CARPENTER Fullback

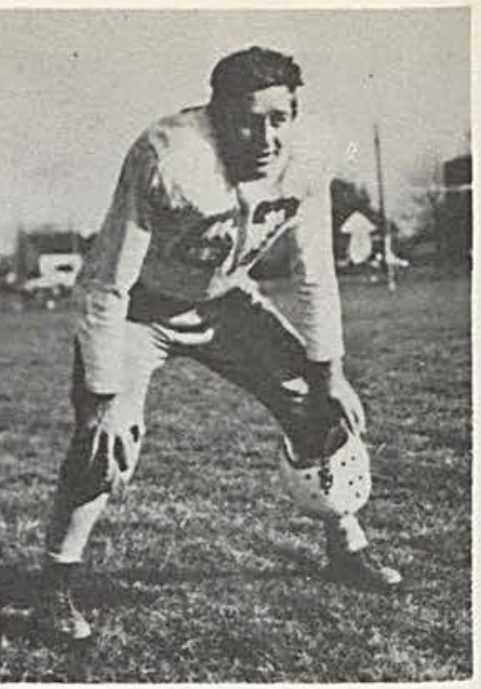

4. E. GROTWOHL Halfback
W. SHEETS, Center

E. KURS, Guard

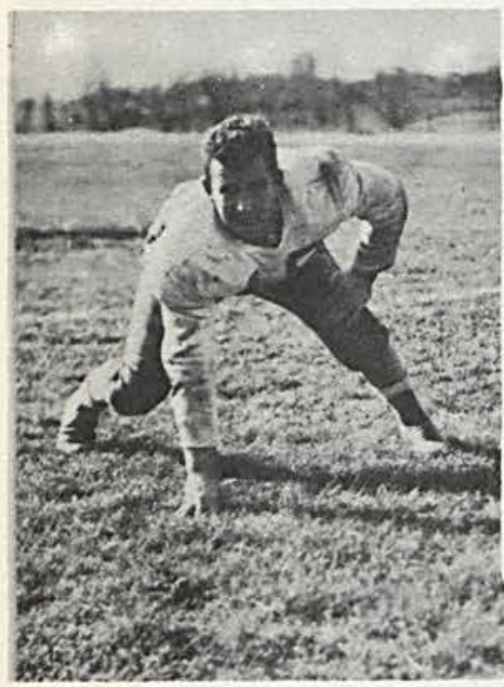

G. CULTICE, End

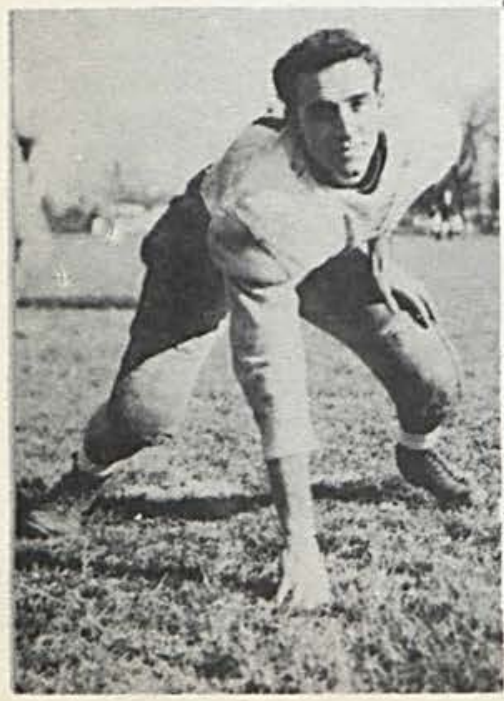

D. STACCS, Guard

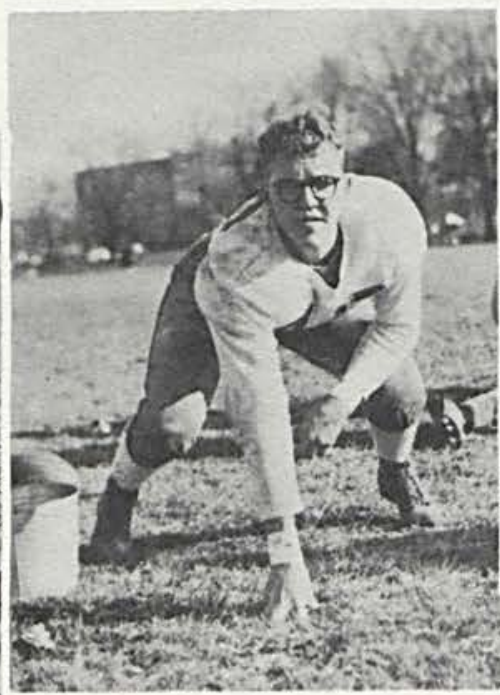

A. SCRIVNER, Tackle

\section{J. HARTMAN, Tackle}

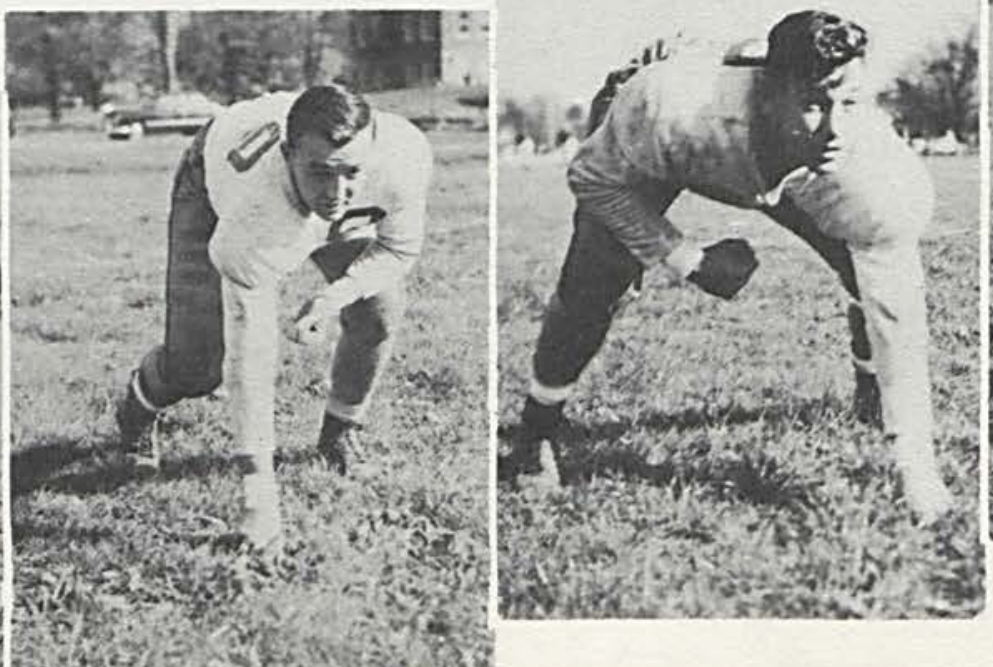

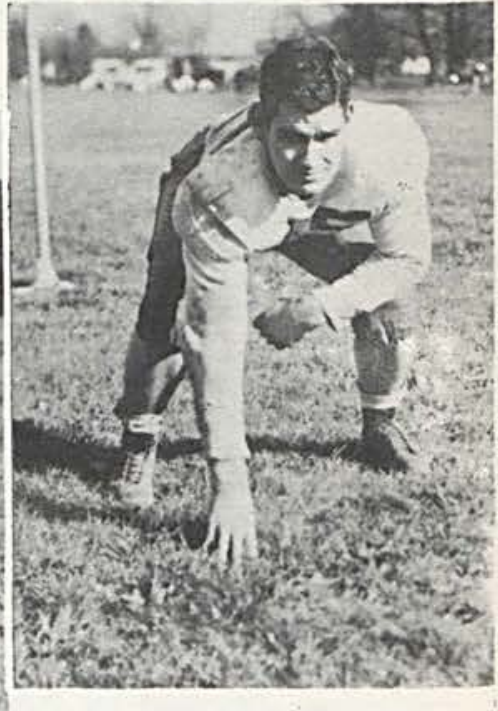

D. KING, Guard
H. BEATTIE, End

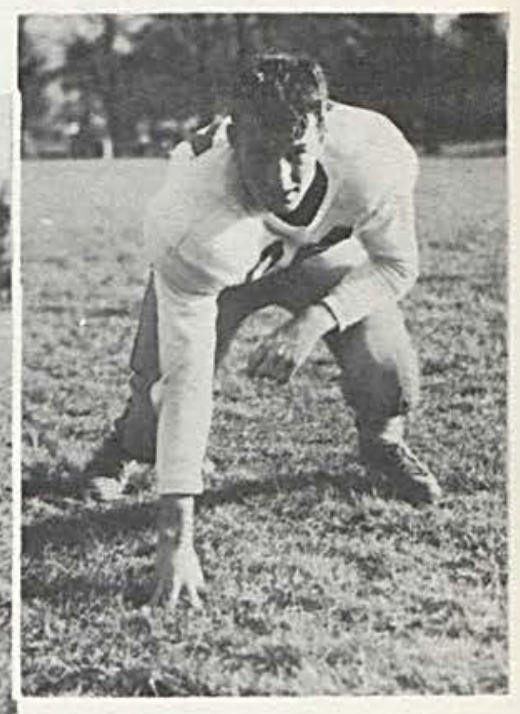



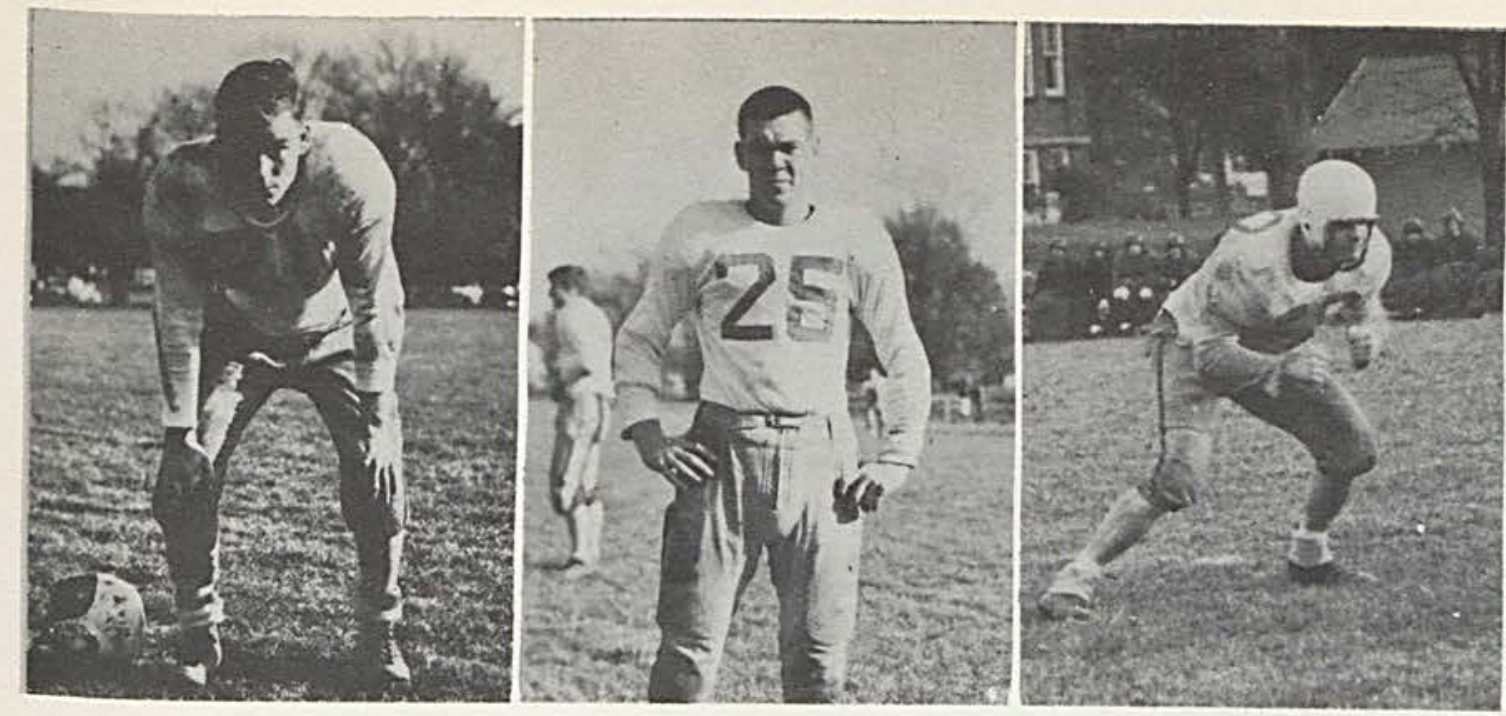

K. WOODS,
Halfback
L. FRENCH
Fullback
D. $\mathrm{COE}$

R. PATER

Halfback
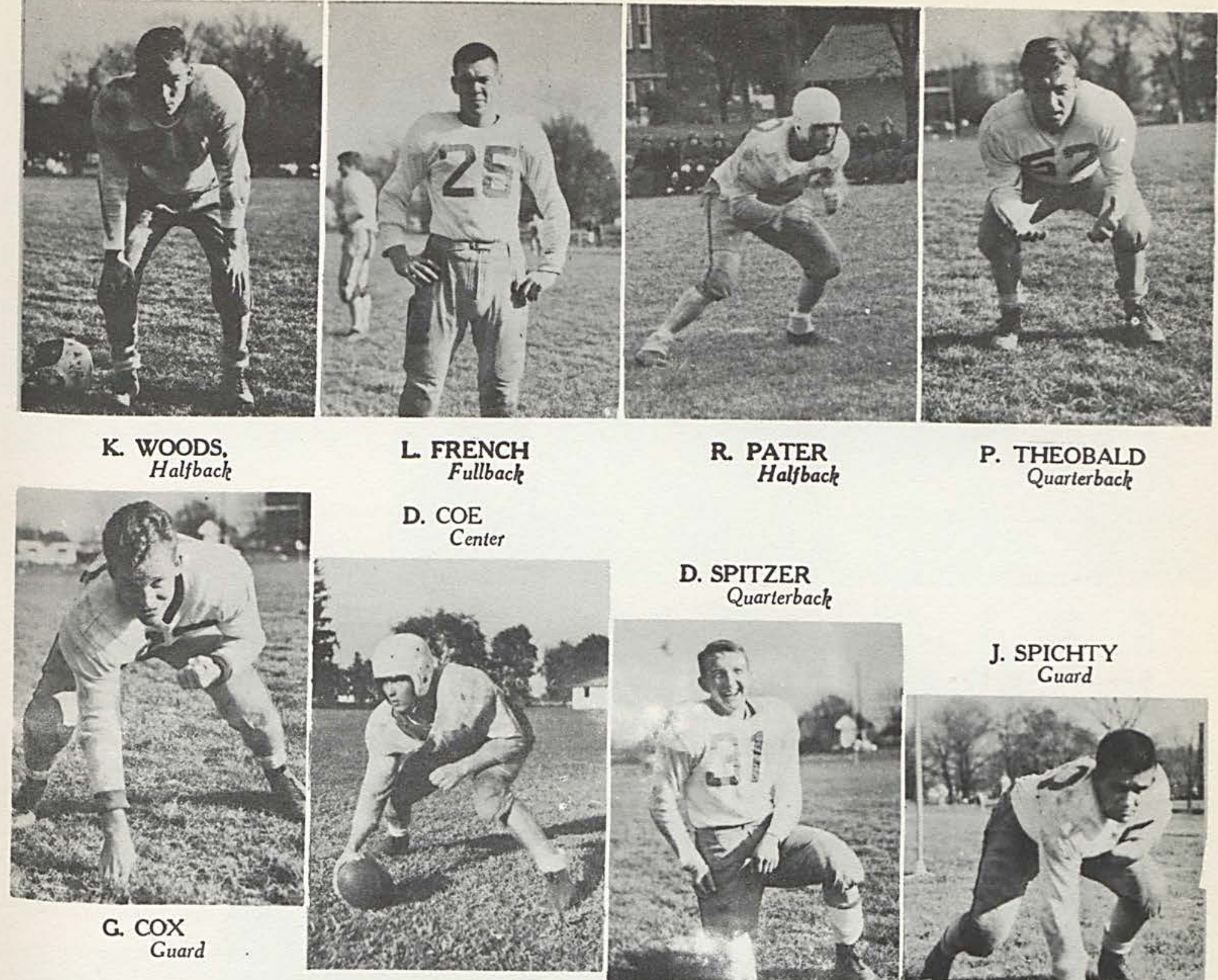

R. NUXHALL End

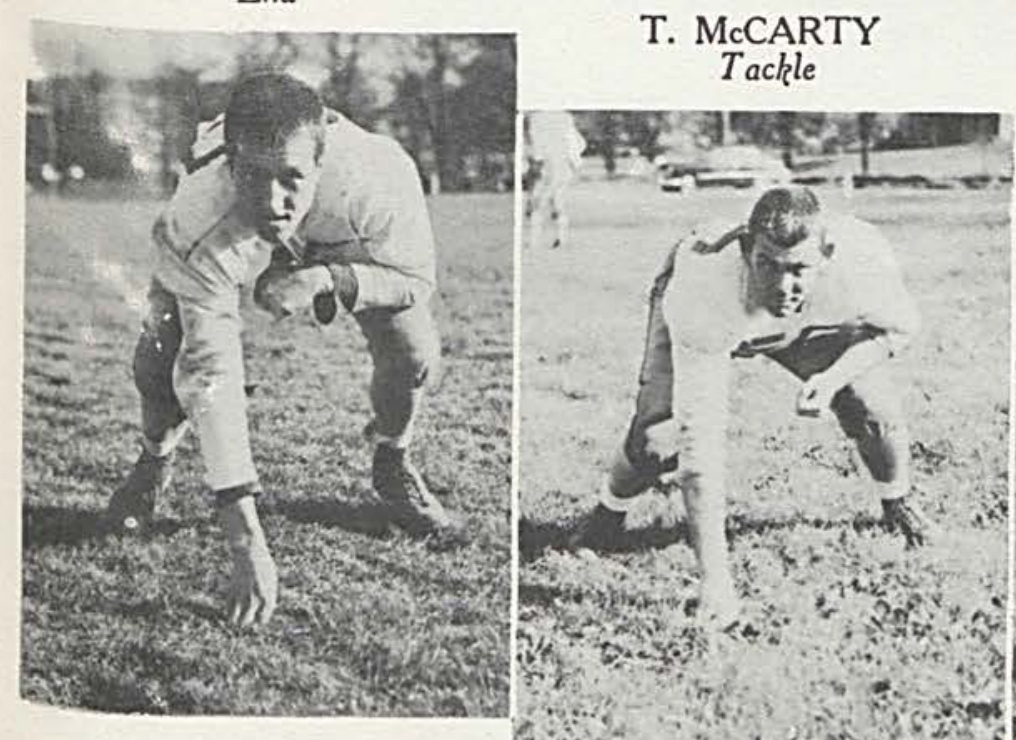

T. MaARTY
Tackle

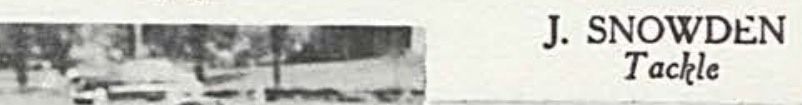

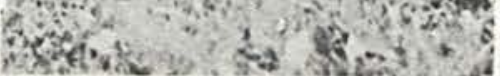

D. SPITZER

Quarterback

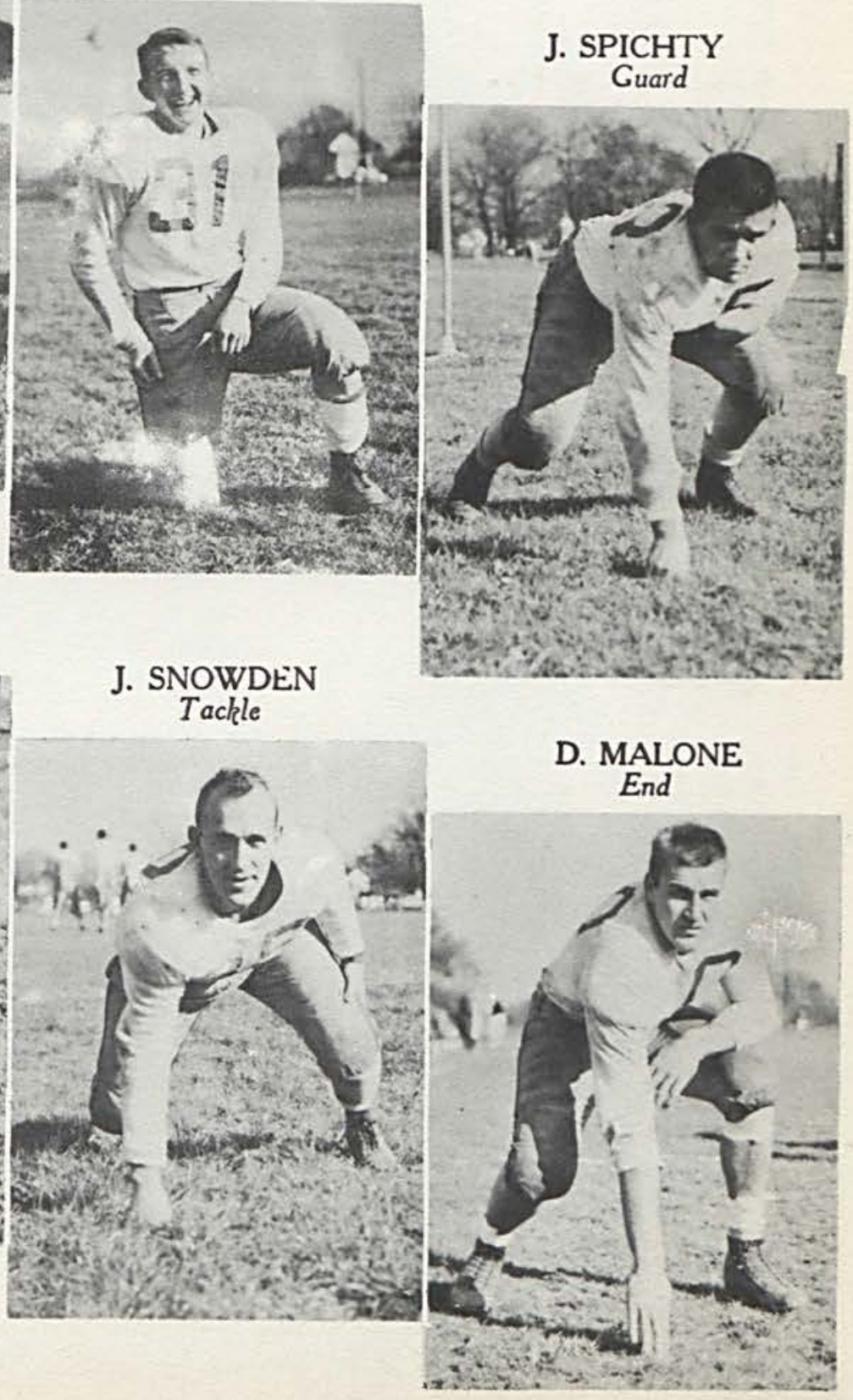




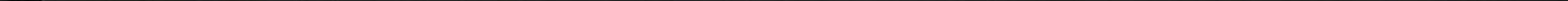



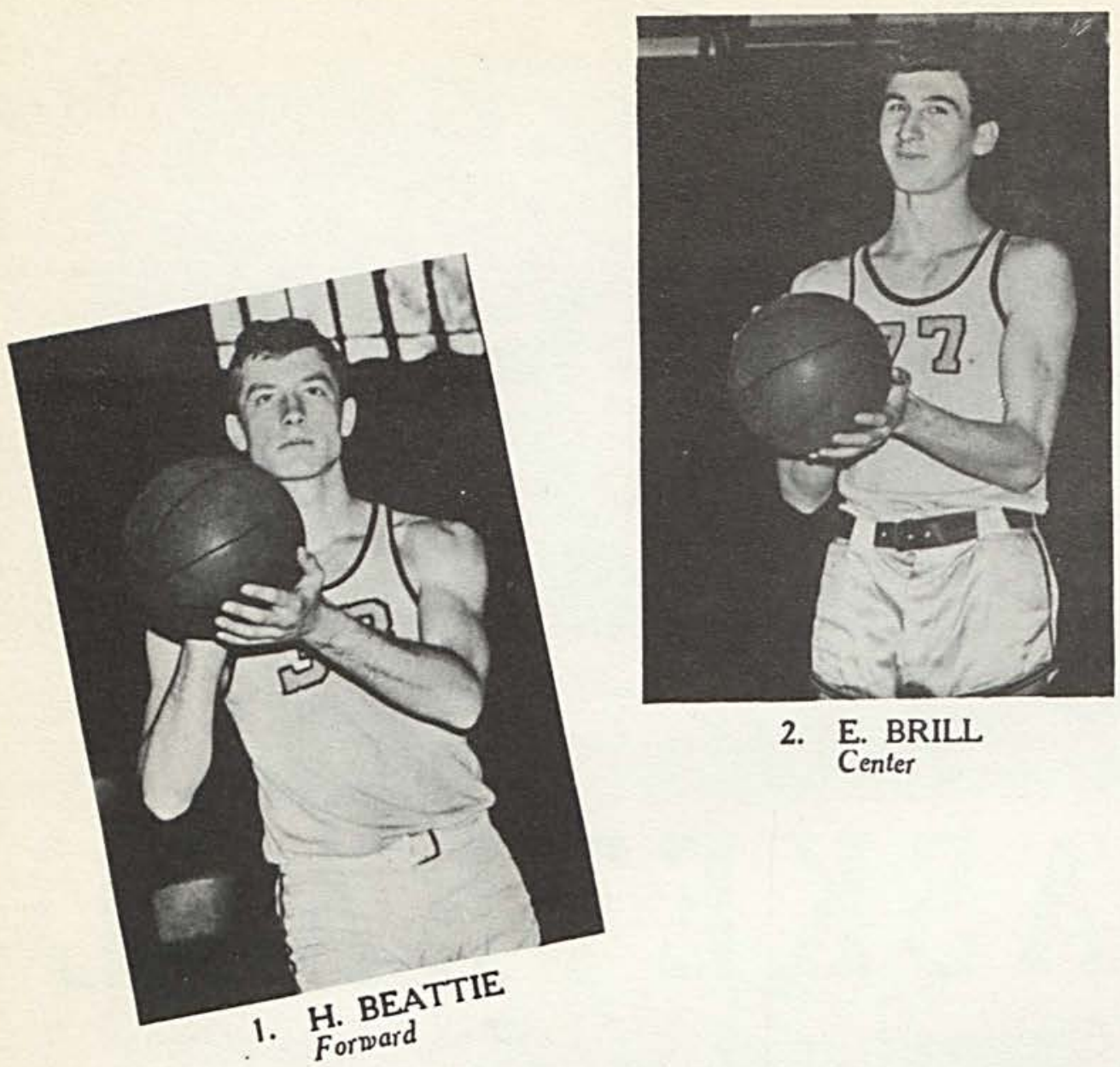
2. E. BRILL Center
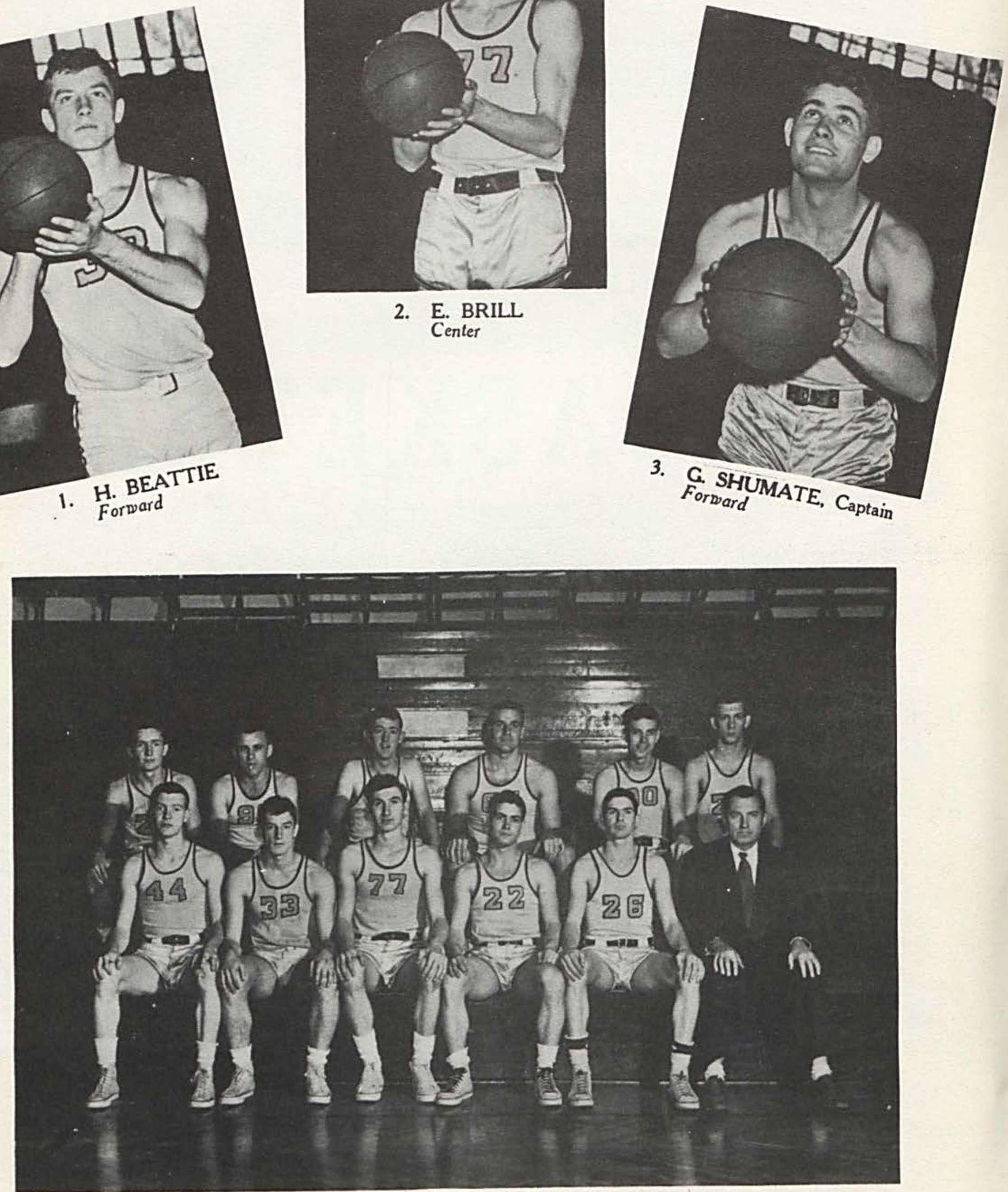

First Ron, left to right: F. Smith, H. Beattie, E. Brill, G. Shumate, E. Downs, M. Beattie-Coach. Second Row, left to right: M. Zell, K. Carpenter, D. Farmer, D. Malone, W. Fife, R. Hatfield. 


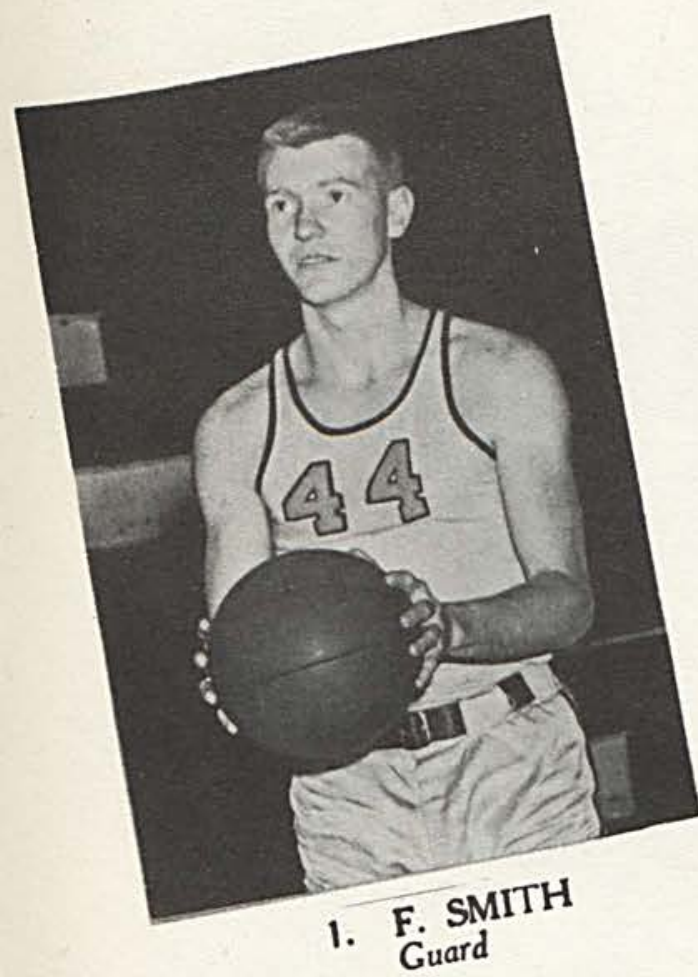

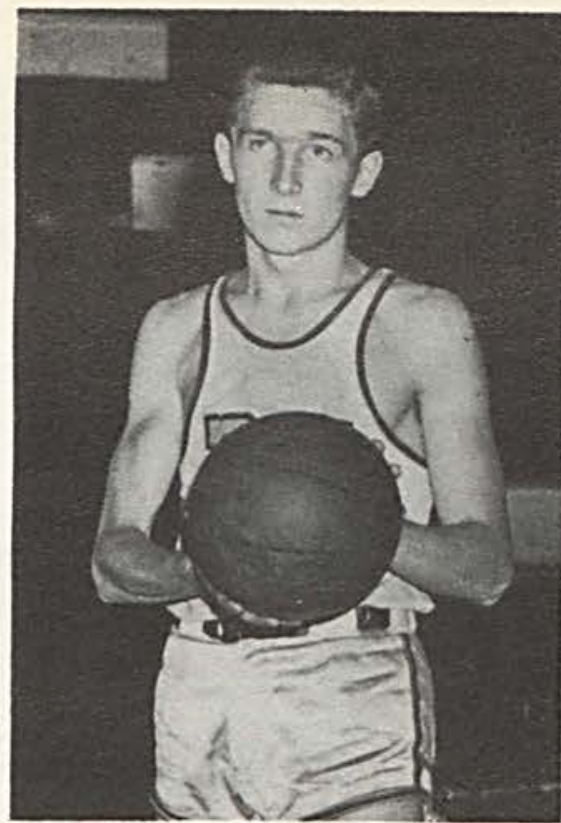

2. M. ZELL Forward

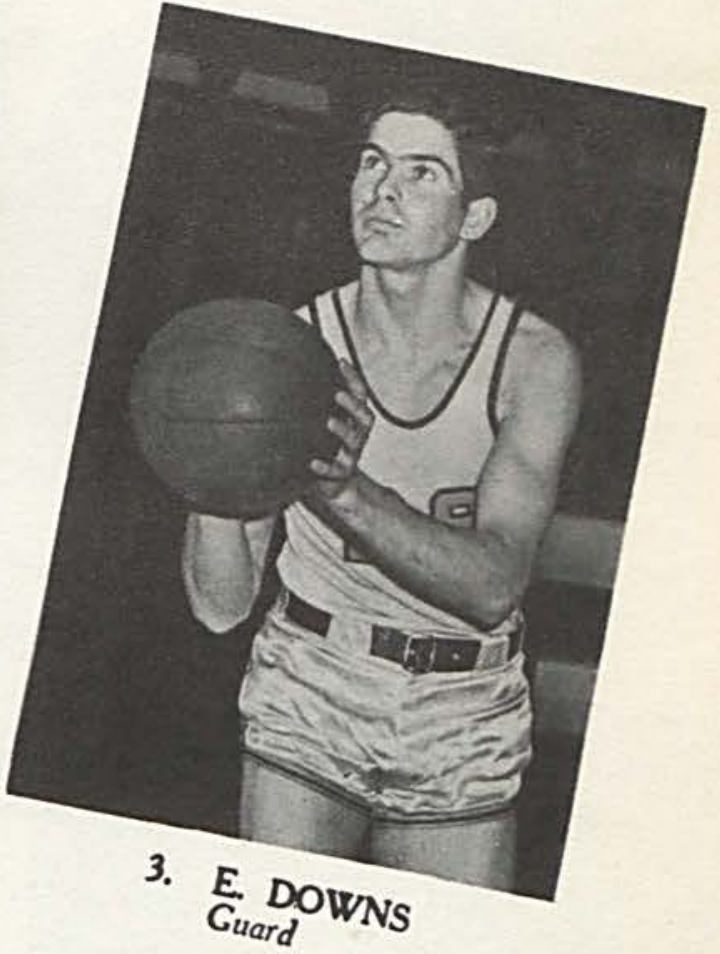

Lack of experience, which many followers agree was the ruination of the Jackets' football season, reappeared on the 1950 . 1951 Cage Squad. Coach Beattie entered the twenty-five game season with only one of his last year's starting five; playing such schools an the University of Cincinnati, Indiana State, Xavier, and other large colleges and universities. The Jackets maintained a fifty-four point offensive average which proved, without a doubt, that they were always a determined squad.

Eddie Brill, lanky six foot three inch center, was chosen on the second team in the Mid-Ohio League and was given honorable mention to the mythical All-Ohio squad. Captain Glen Shumate, star forward, was placed on the Mid-Ohio third team.

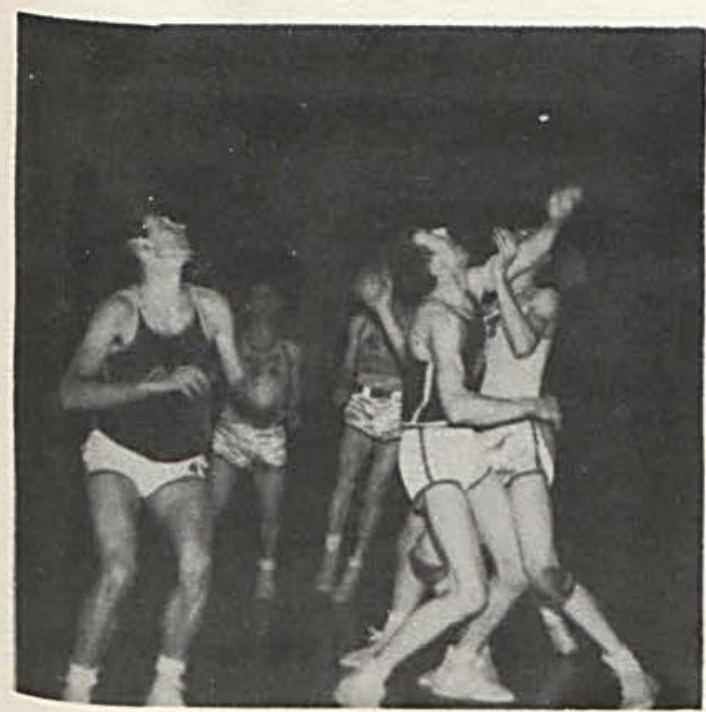

5. ACTIONI
Cedarville College 75

Cedarville College 43

Cedarville College 58

Cedarville College 44

Cedarville College 56

Cedarville College 39

Cedarville College 69

Cedarville College 52

Cedarville College 52

Cedarville College 59

Cedarville College 56

Cedarville College 67

Cedarville College 58

Cedarville College 54

Cedarville College 60

Cedarville College 73

Cedarville College 63

Cedarville College 78

Cedarville College 63

Cedarville College 54

Cedarville College 67

Cedarville College 61

Cedarville College 73

Cedarville College 48

Cedarville College 56
Chase 76

Xavier 91

Villa Madonna 62

Cincinnati 112

Morehead State 85

Indiana State 73

Huntington $65^{-1}$

Defiance 64

Wilberforce State 86

Ashland 75

Ohio Northern 84

Findlay 78

Wilmington 69

Bluffion 67

Ohio University 77

Bluffton 68t

Ohio University 70

Defiance 79

Wilmington 64

Villa Madonna 56

Ohio Northern 70

Wilberforce State 68

Chase 68 -

Findlay 64

Huntington 65 


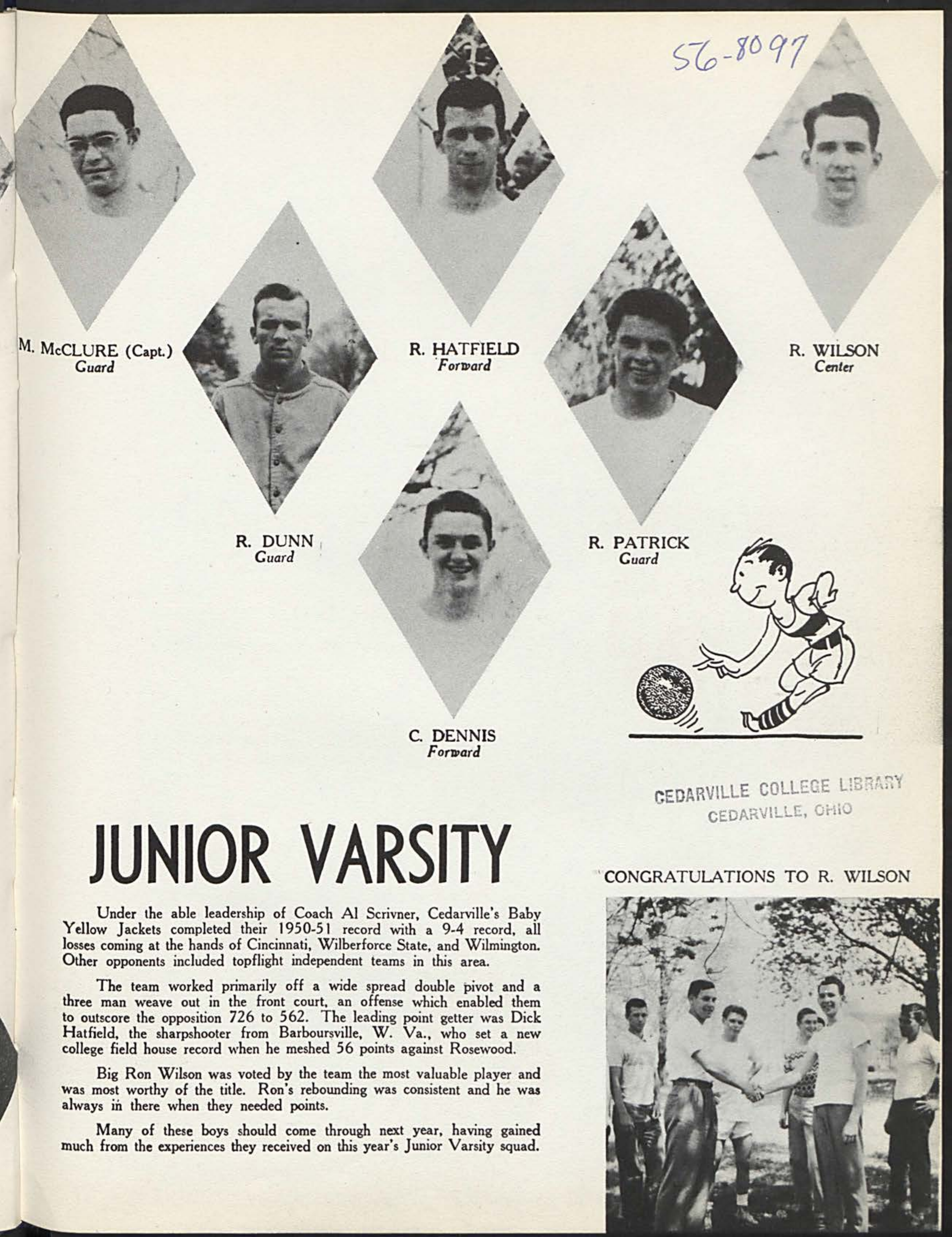




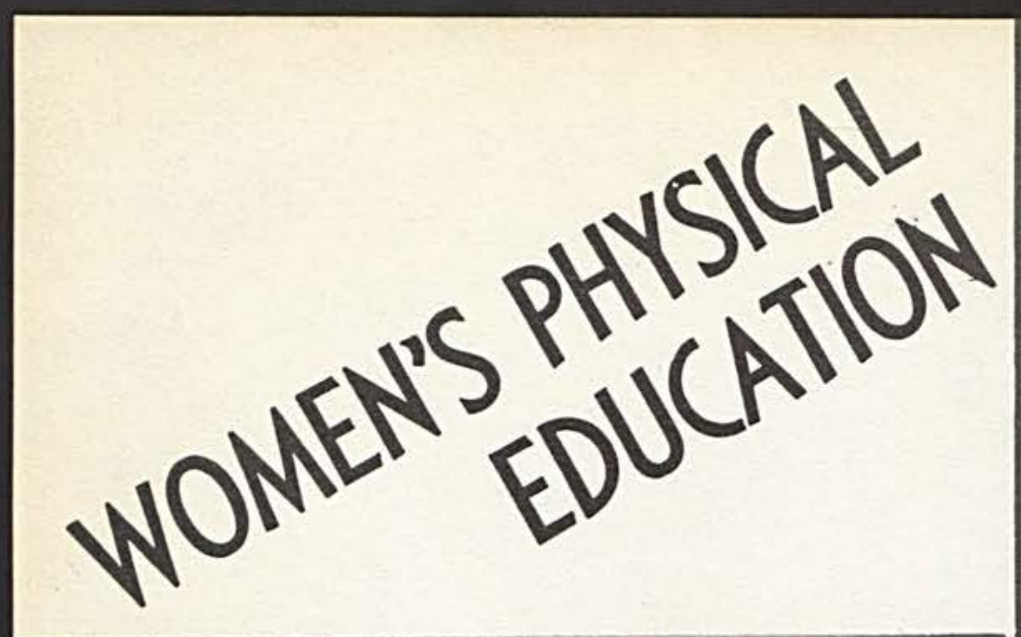

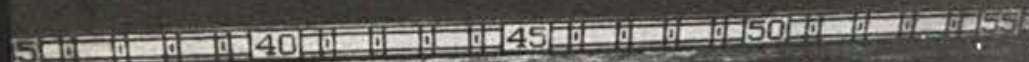

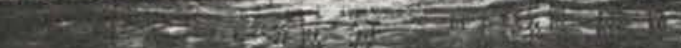

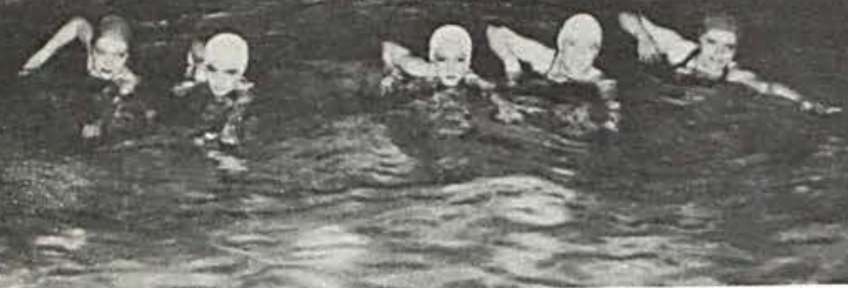

$$
\text { Hस }
$$

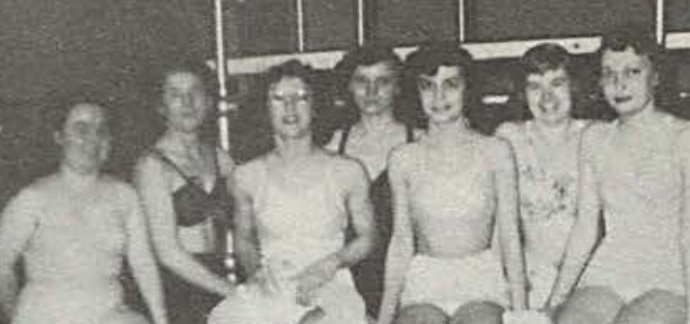

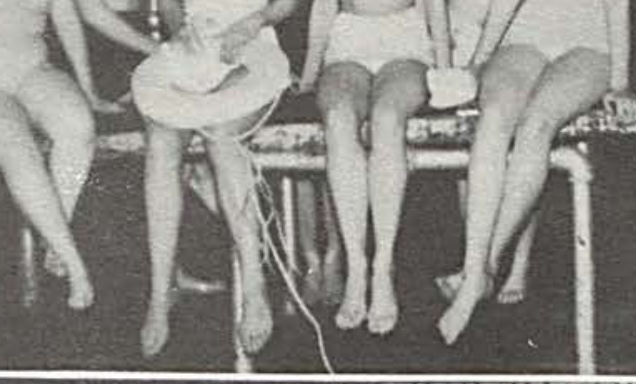

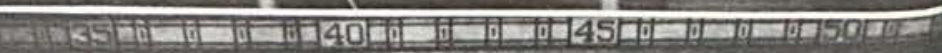
contin:-

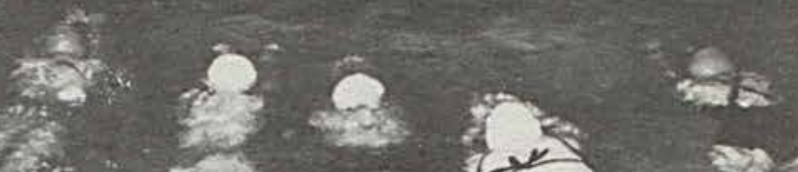

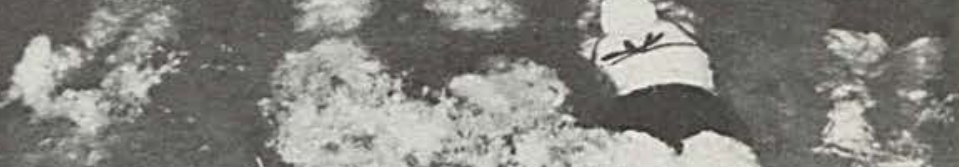

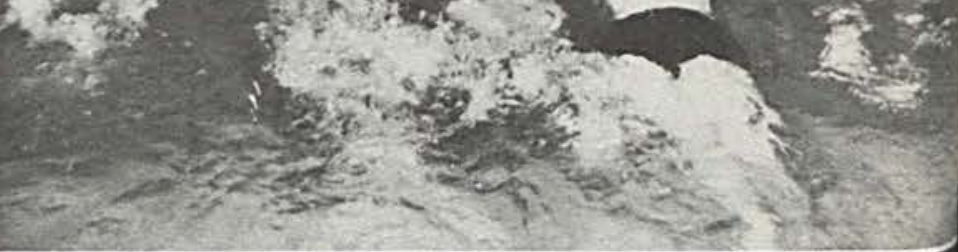
.
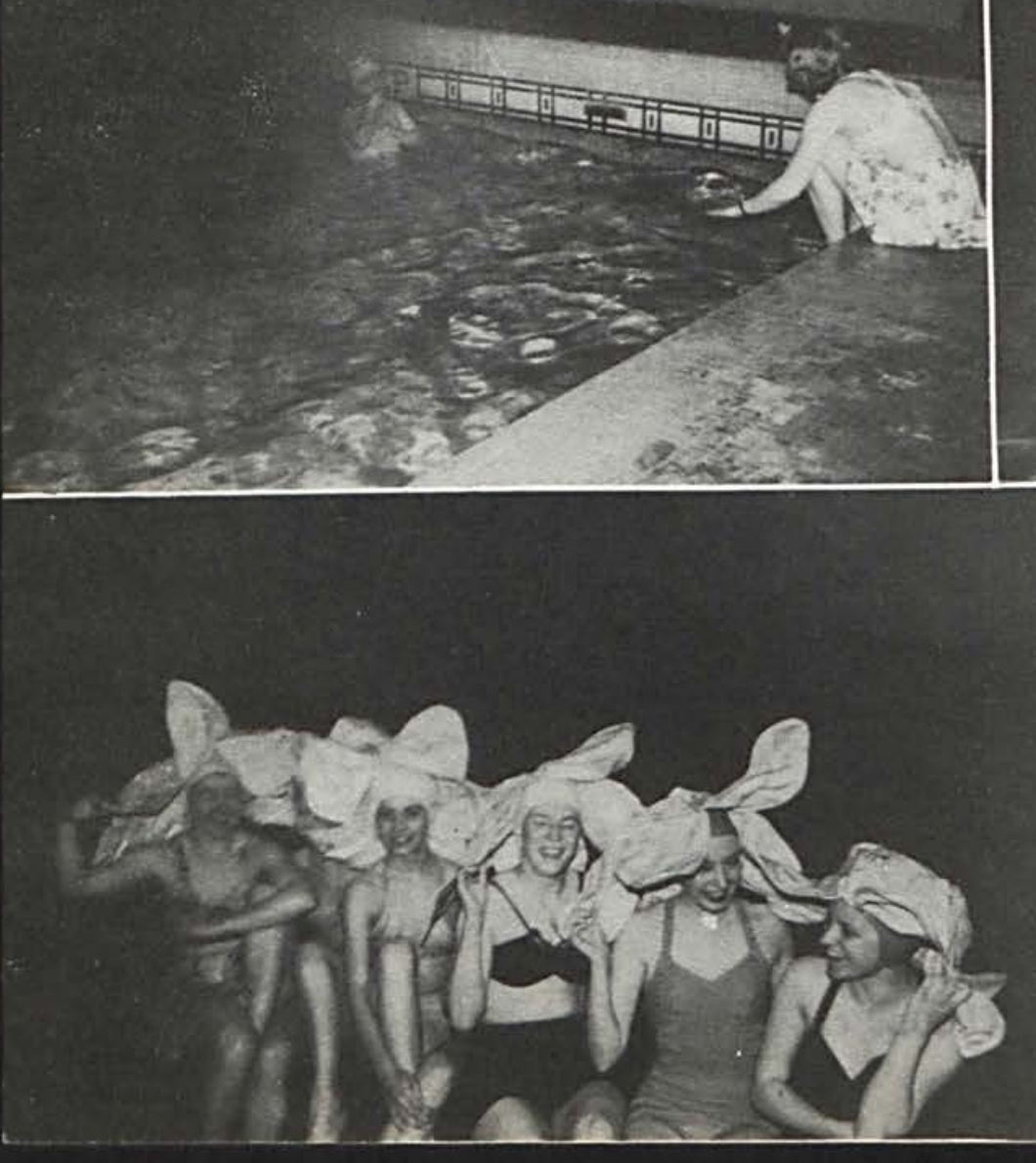

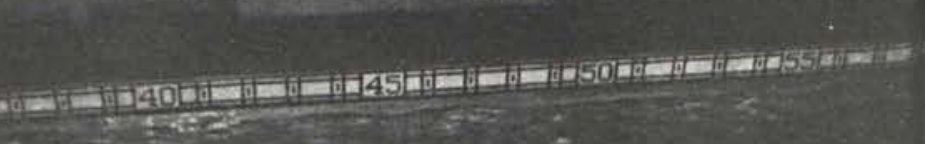

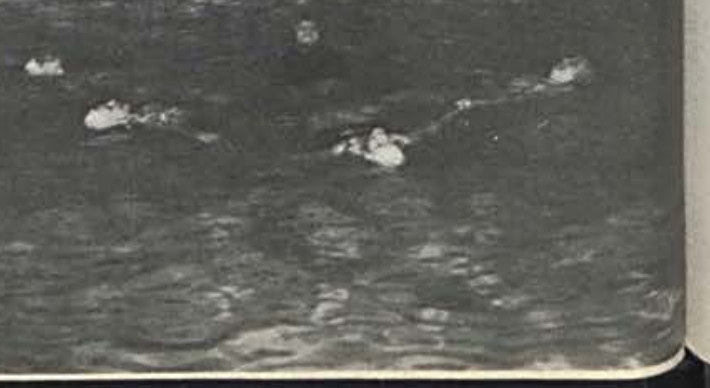




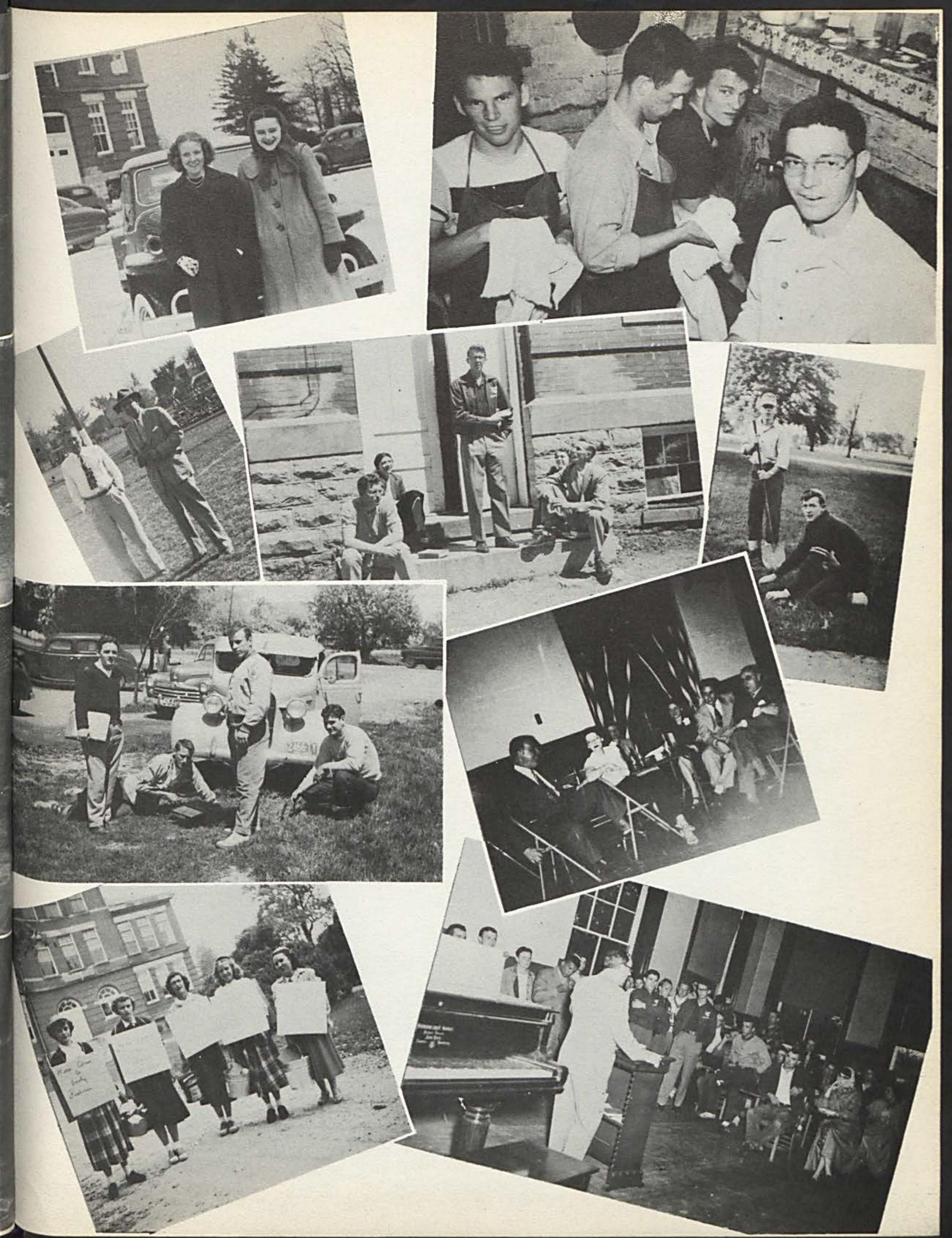




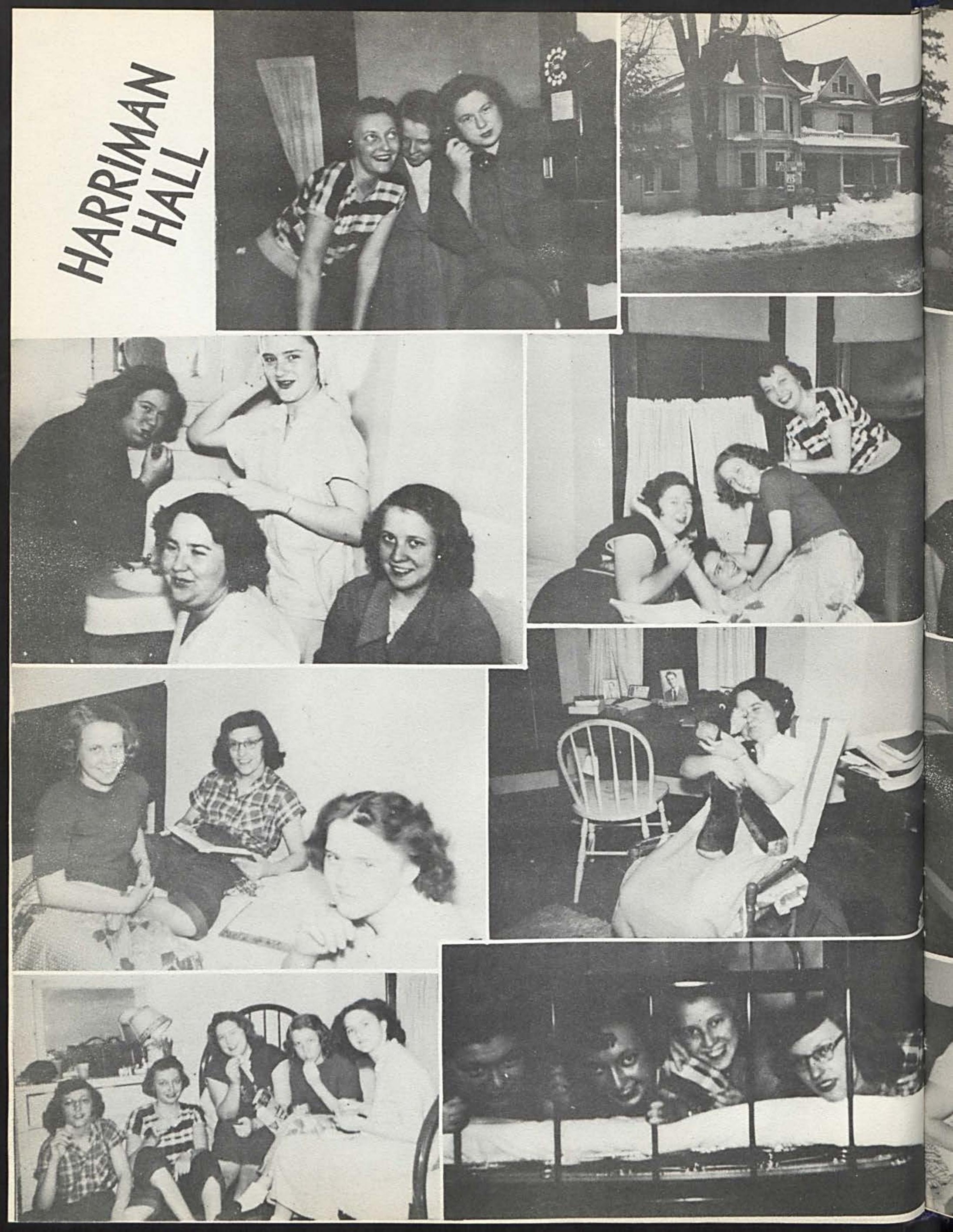




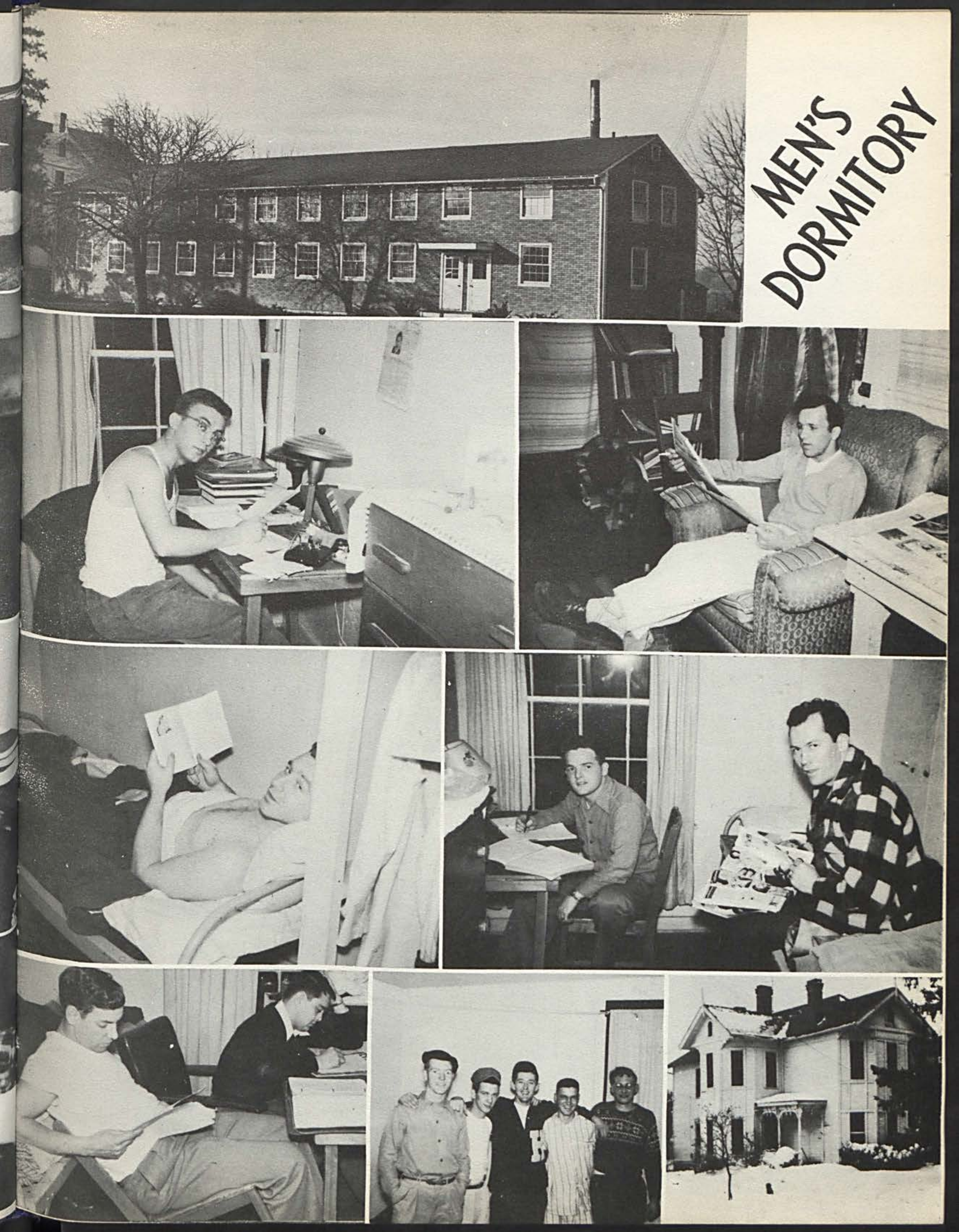




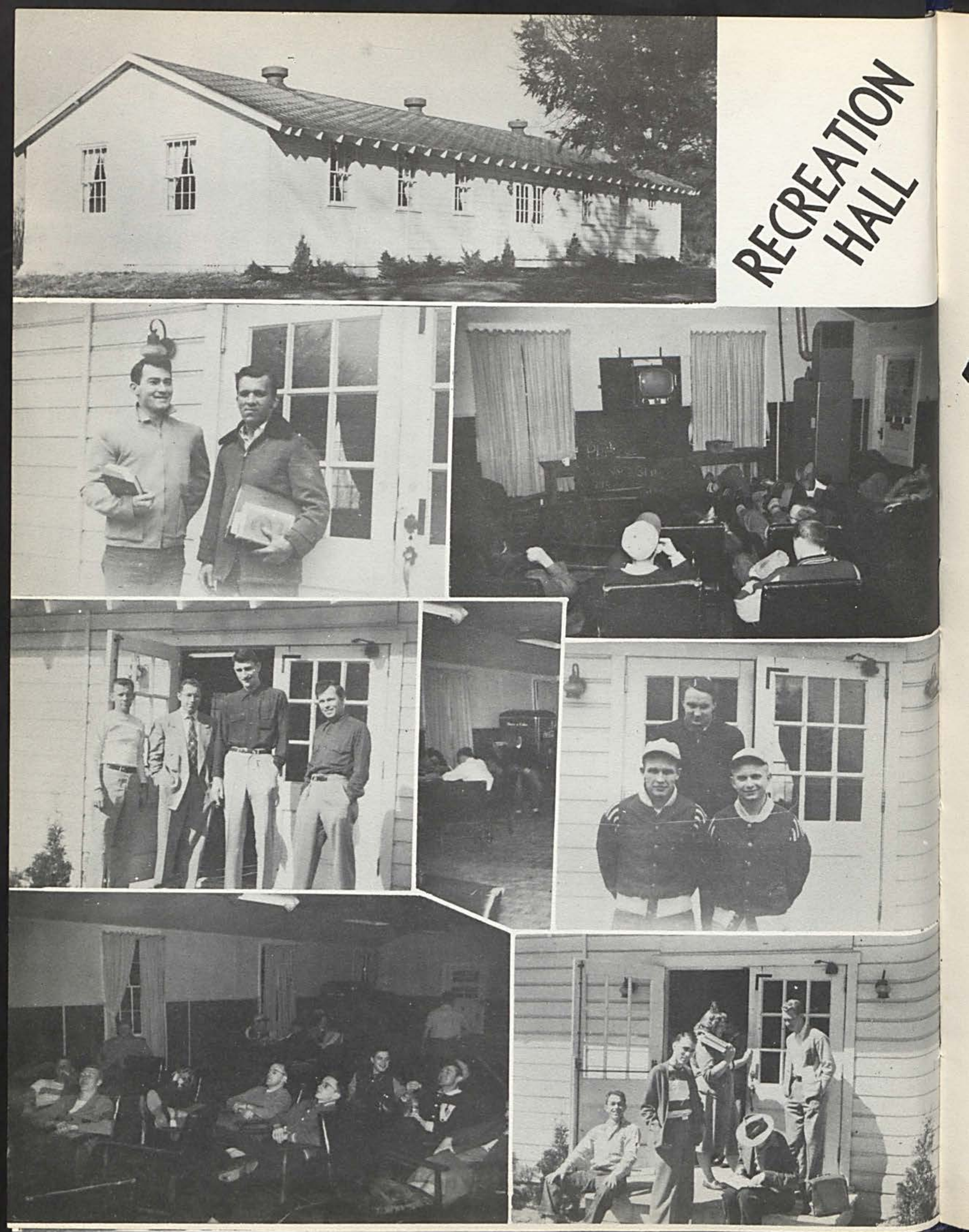




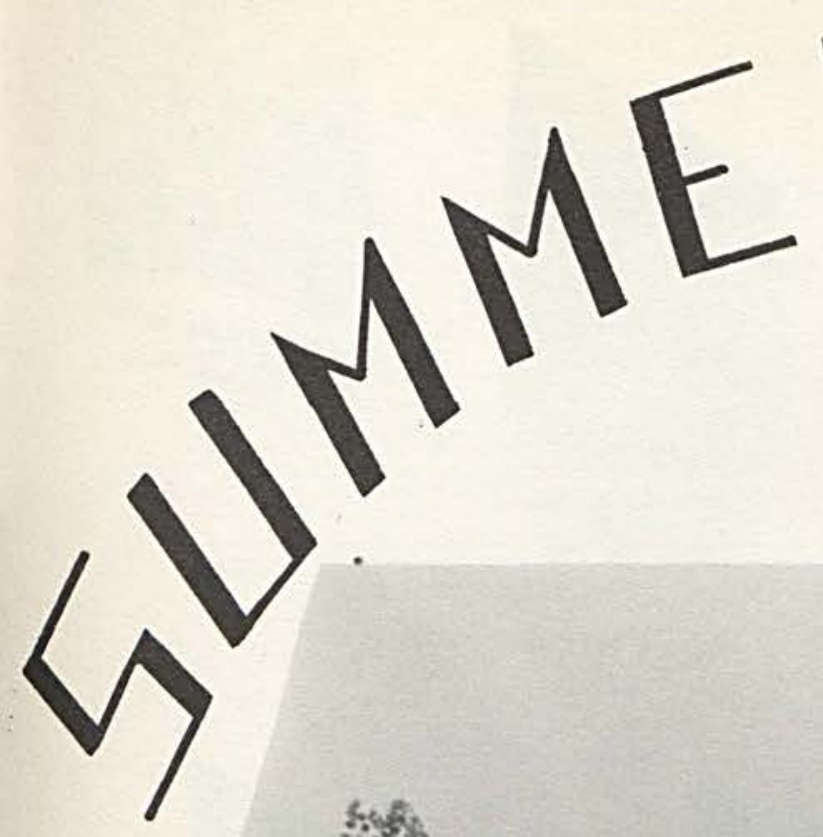

stis

$-\mathrm{SO}^{2} \mathrm{~s}$

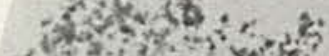

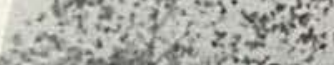

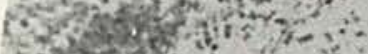

H. 135 ,

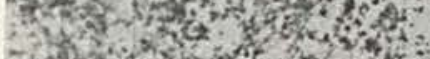

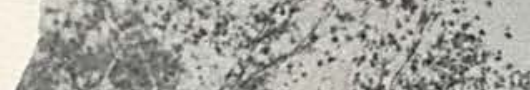

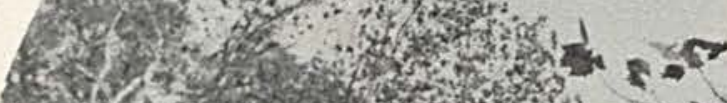

2.
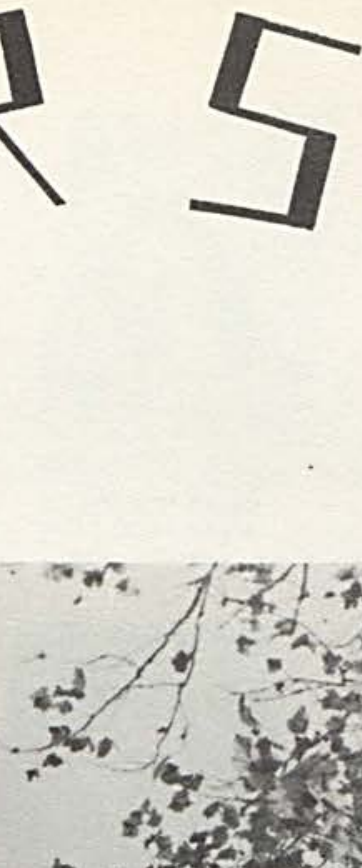

17

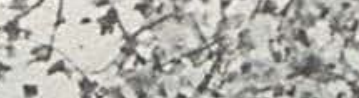

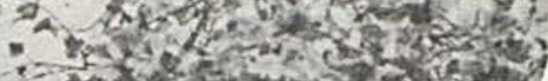

3.31 .

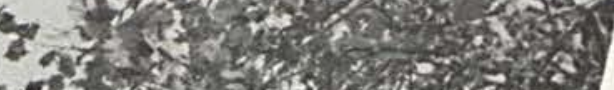

w.

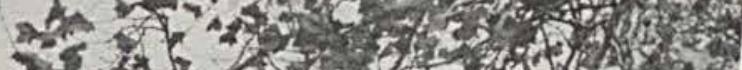

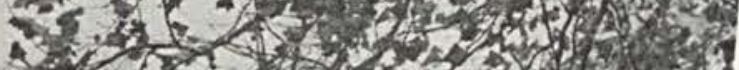

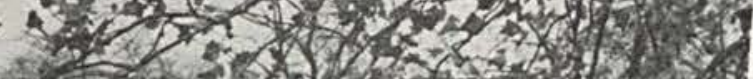
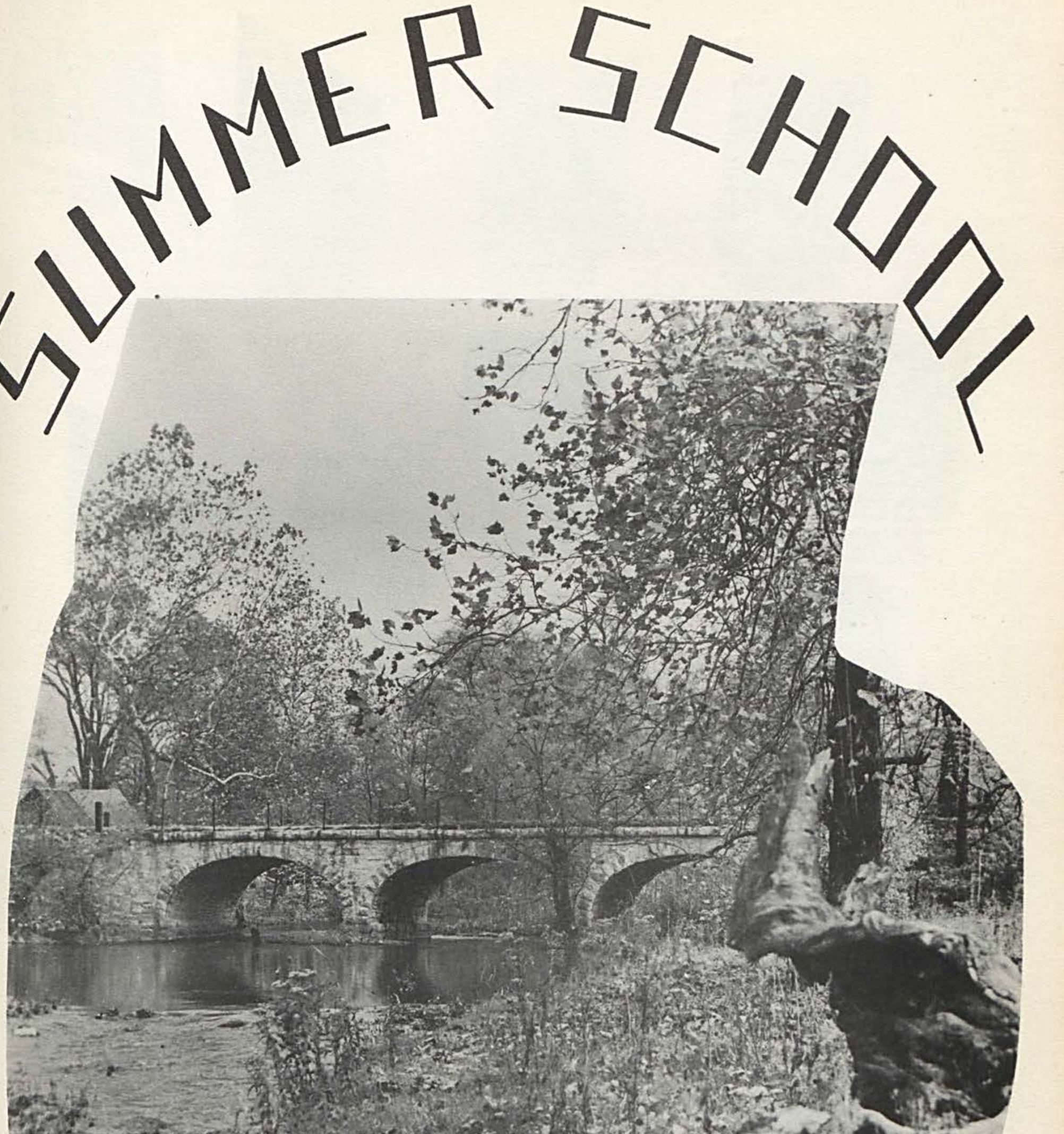

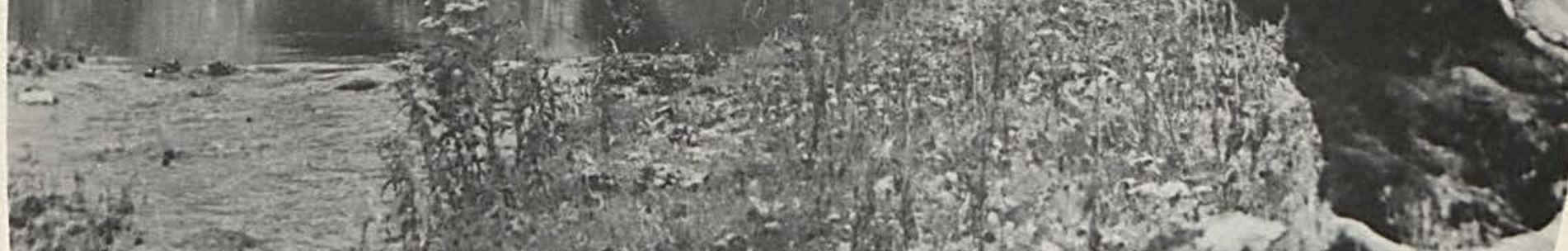
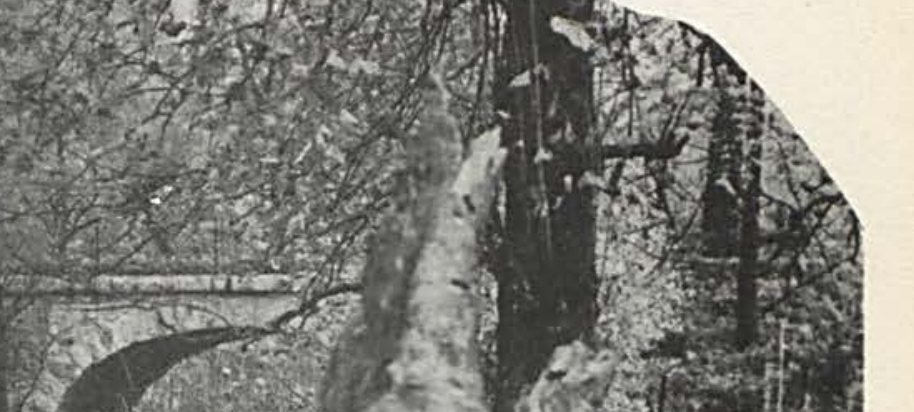
mas m. $2 \mathrm{c}$ (x) 5 . (2) I. wis. Wh:

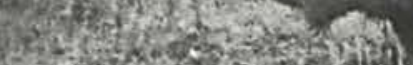

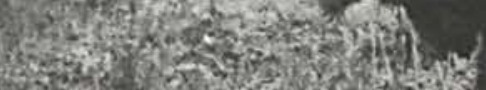

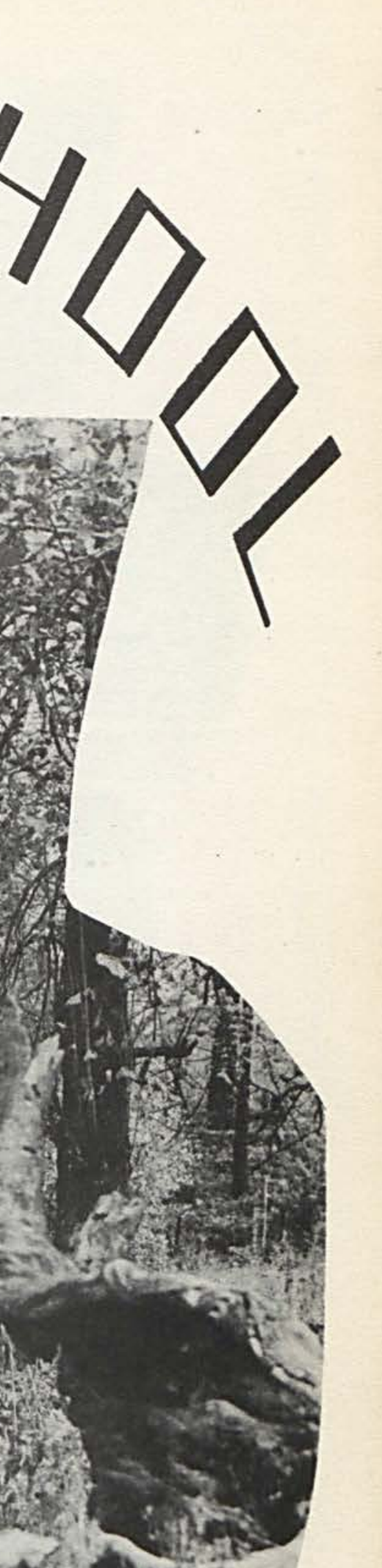
Yox

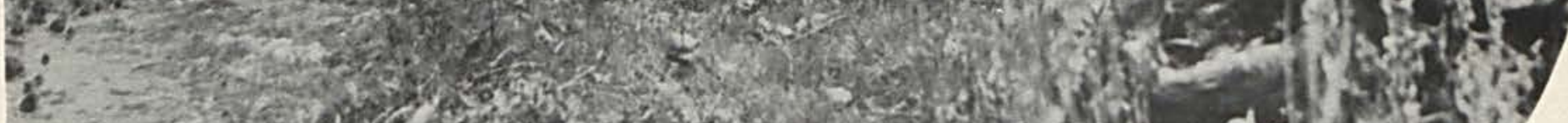

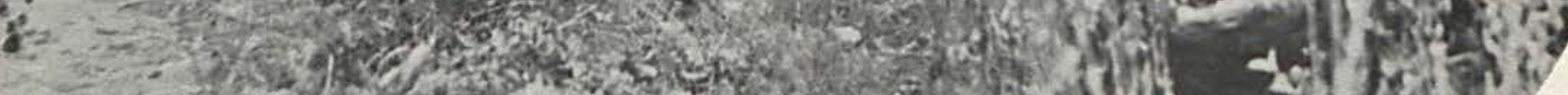

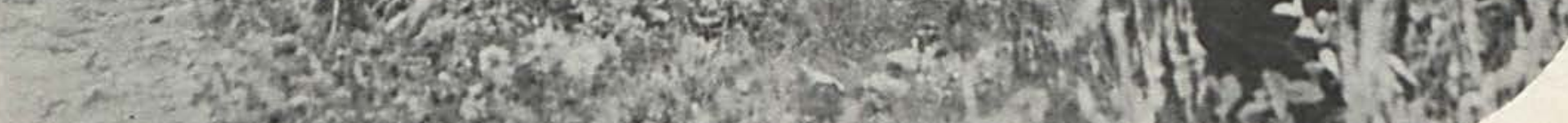

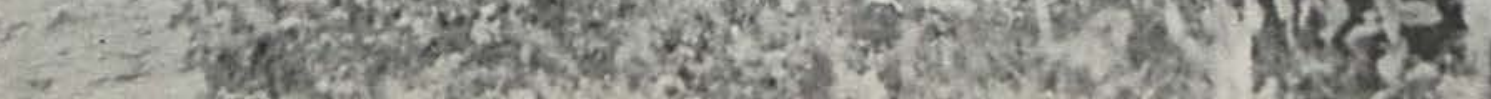



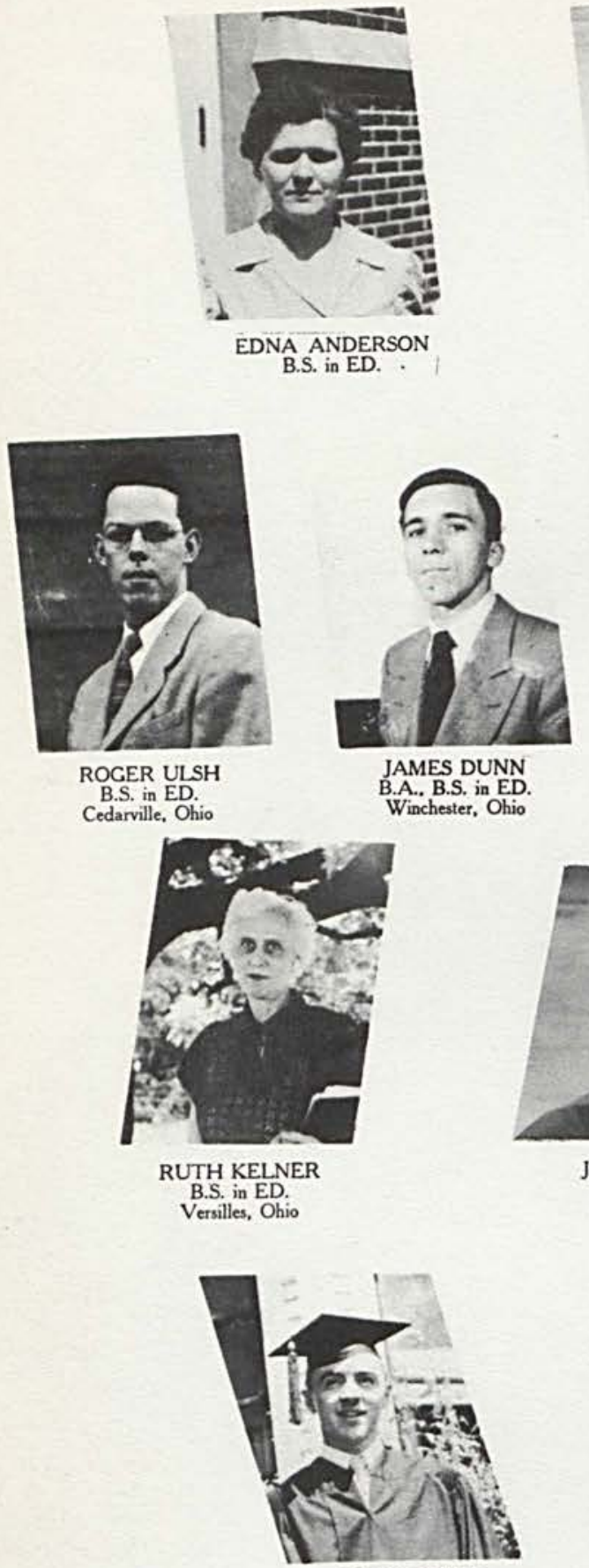

$$
\text { JAMES LEWIS }
$$$$
\text { Soush Webster, Ohio }
$$
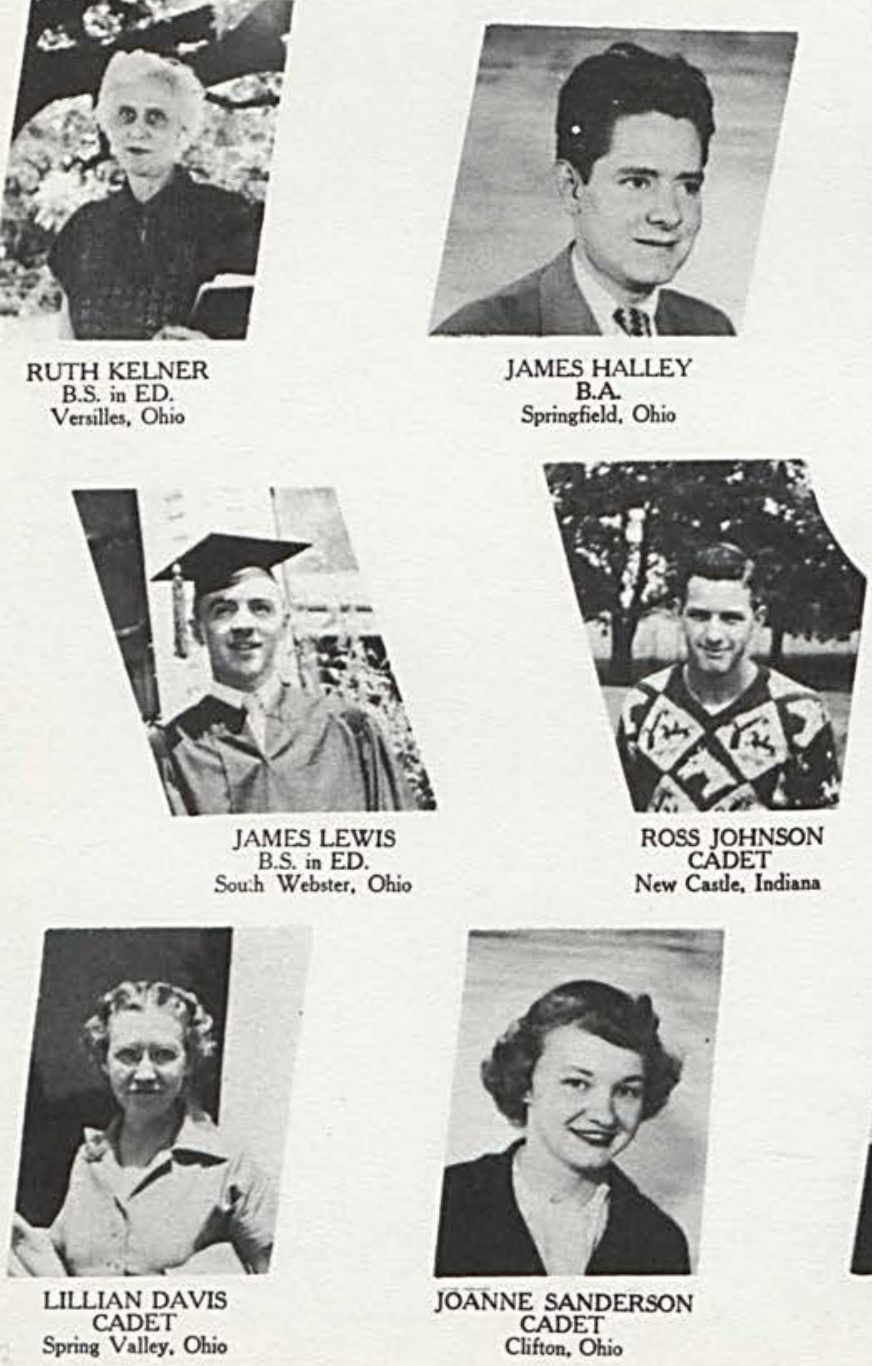
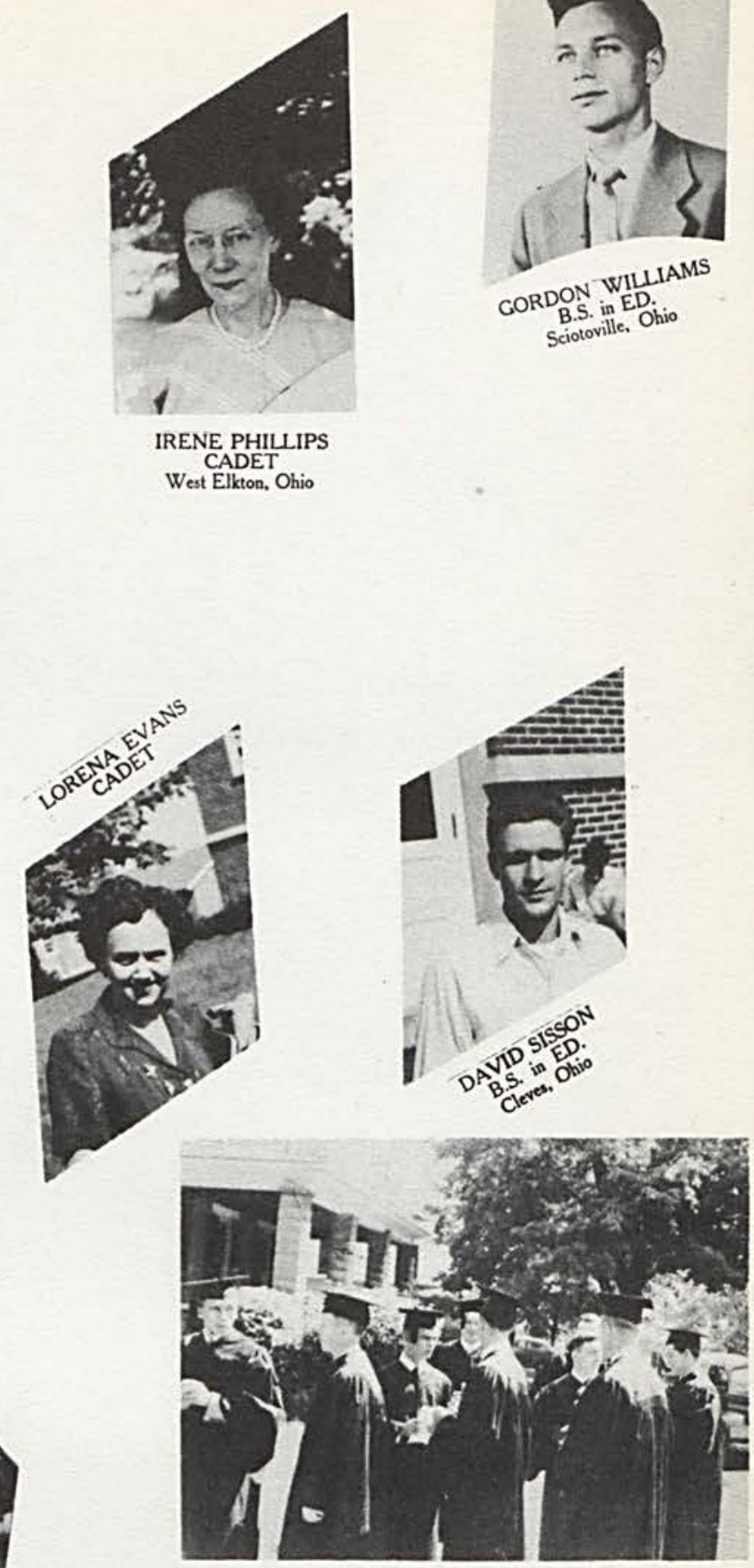

\section{Graduates of}

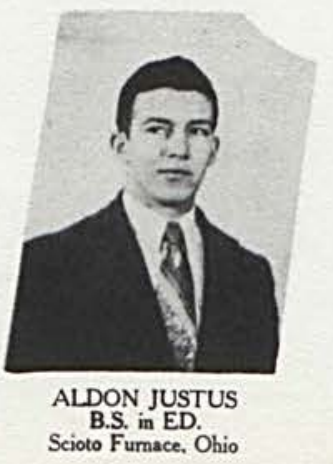

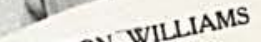

GORDON WILLA

B.S. in EDille. Ohio
Sciotovile. 


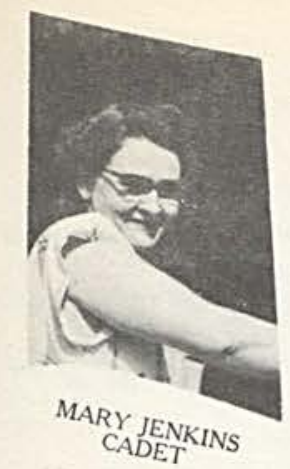

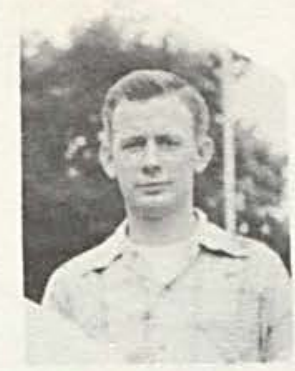

WILIAM OSMAN

B.A. CUME LAUDE
Paso Robles, Calif.

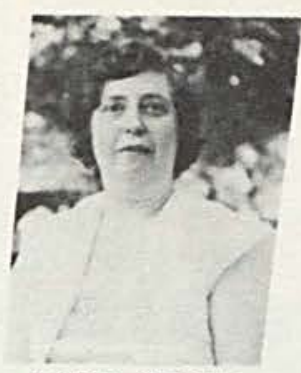

LORNA CRAIGIE Xenia, Ohio

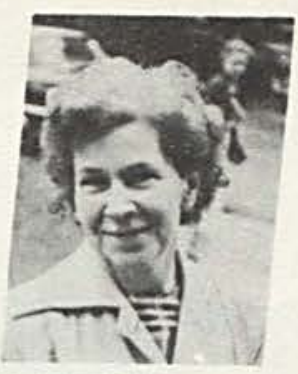

ELEANOR MITCHNER

New Burlington, Ohio

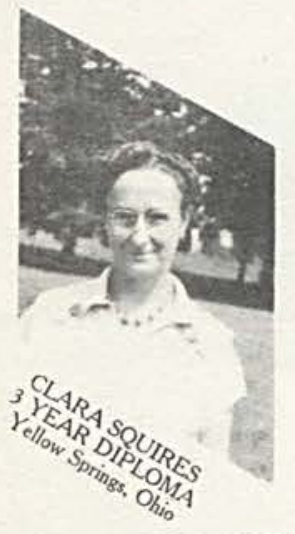

\section{IIIIIIIIIII}
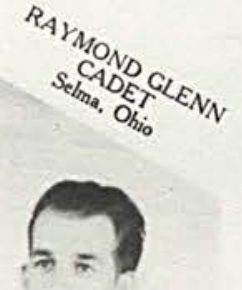

CAROLYN BURROUGHS

B.A. CUME LAUD
Cedarville, Ohio
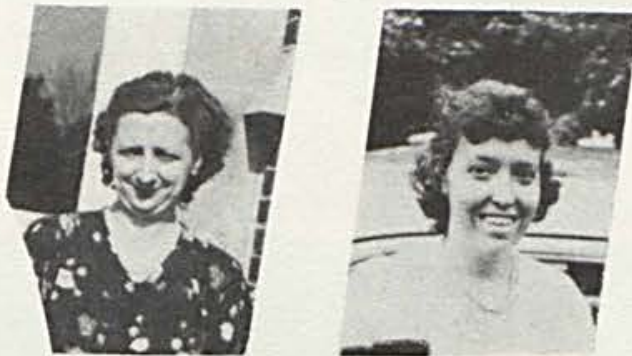

JANE WALKER PRICE

B.S. in ED.

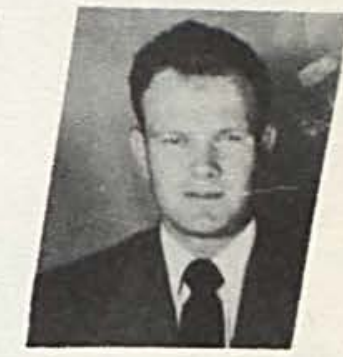

WILLIAM HAMMOND

B.S. in ED.

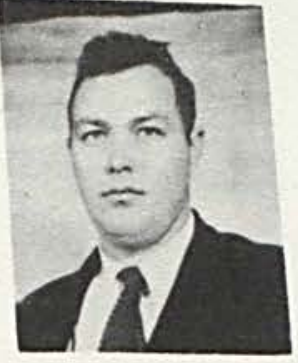

BION BRADBURY Cedarville, Ohio

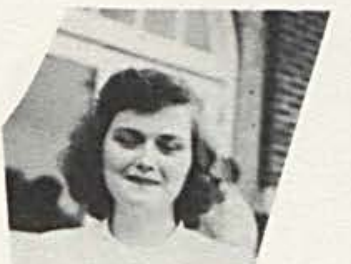

August 1950
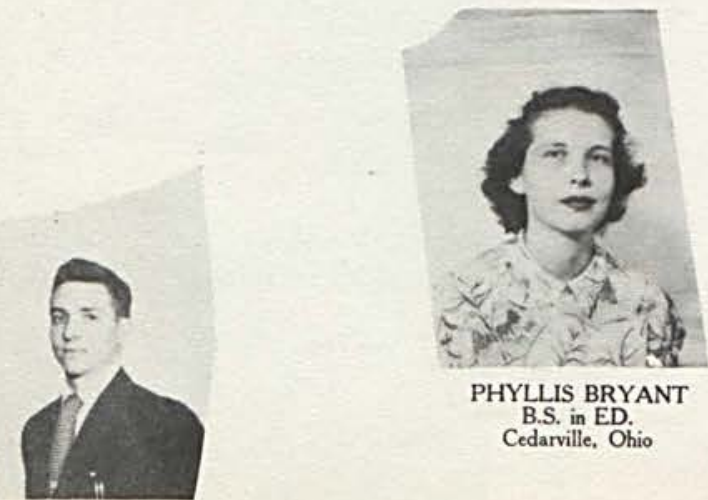

PATRICIA GRIEVE
3 YEAR DIPLOMA
Xenia, Ohio

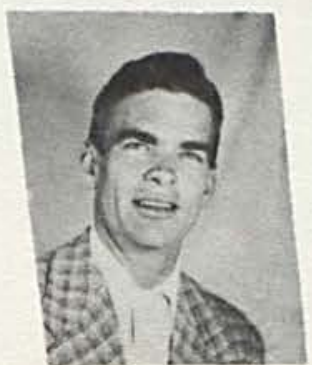

PHYLLIS BRYANT

B.S. in ED.

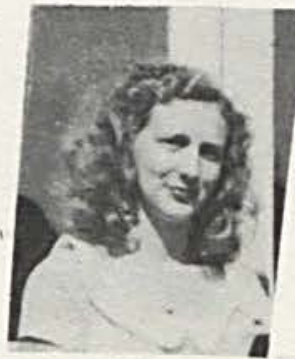

LENORE FLANNERY YEAR DIPLOMA Plattsburg, Ohio

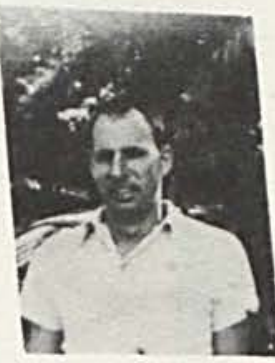

DONALD STRASBURG B.S. in ED. 

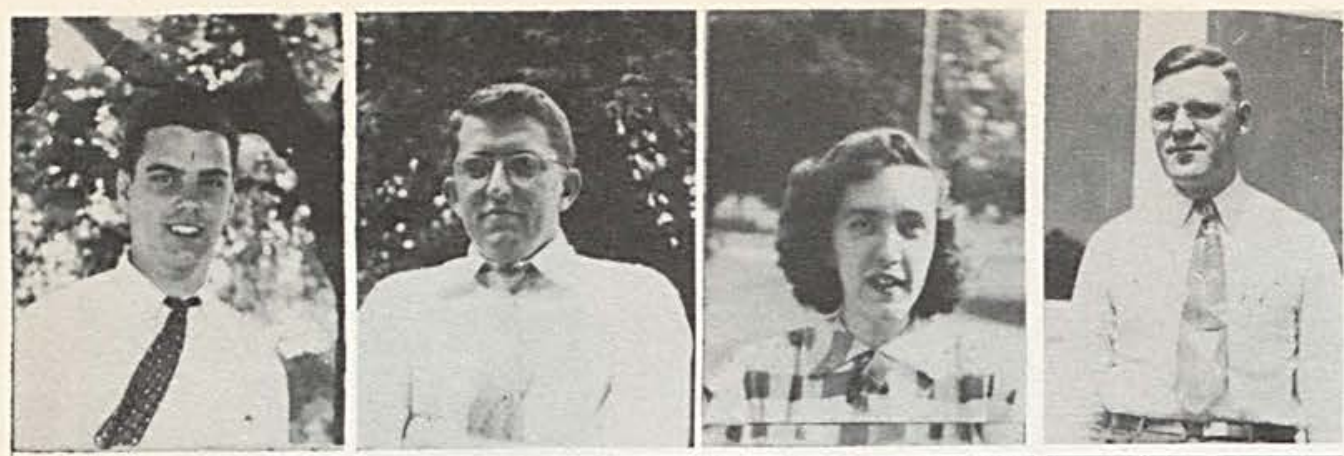

JAMES RAMSEY, Biology DONALD GAST, History NANCY BOST, Music FREDRICK CARLSEN, Bible
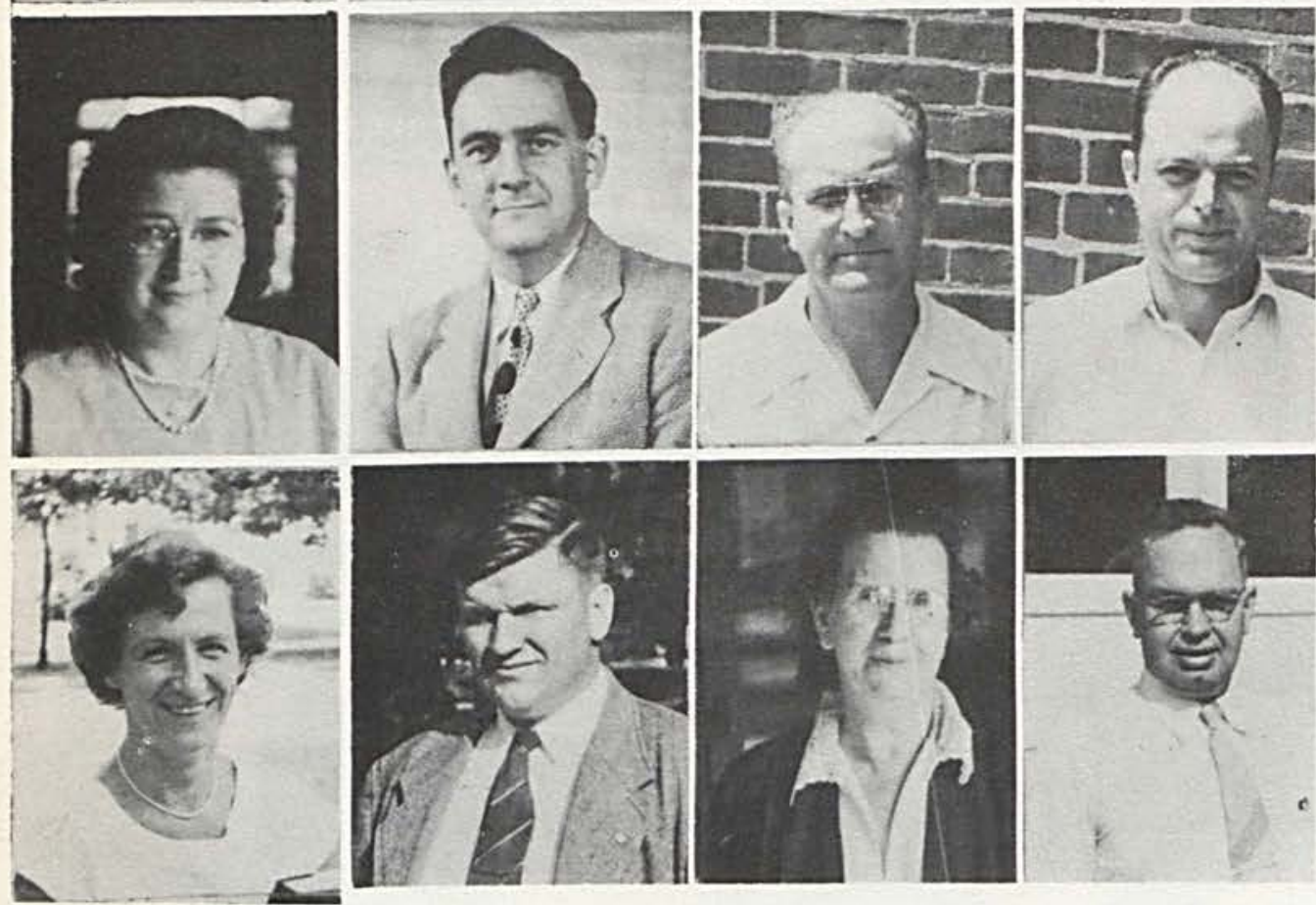

EDITH STANGLAND,

Physical Ed.

ELWOOD SHAW, Chemistry BERTHA NIXON, Elementary L. R. HORNER, Education

OLIVE CARLSEN, English
GILBERT DODD, Geography JAMES HALL, Registrar HOWARD WISE, Mathematics

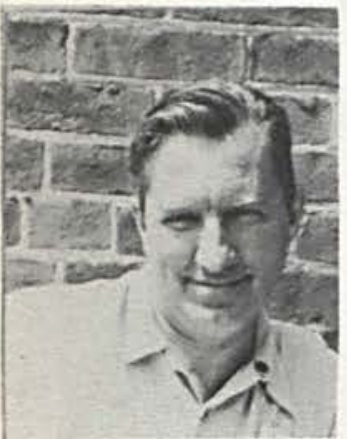

MENDELL BEATTIE,

Director of Summer School

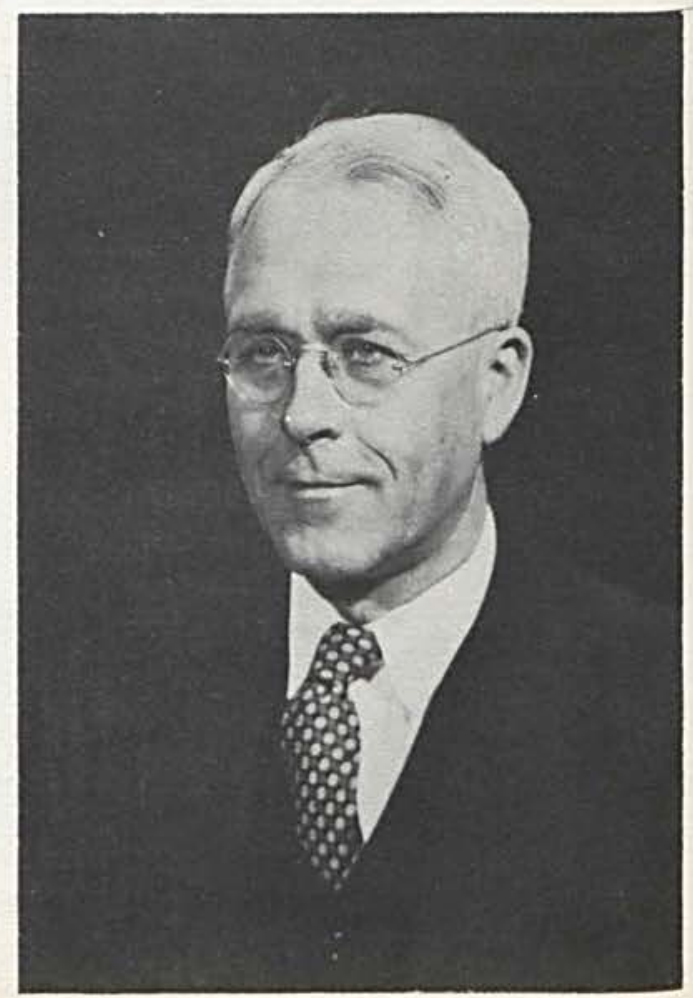

IRA D. VAYHINGER, D.D., President 


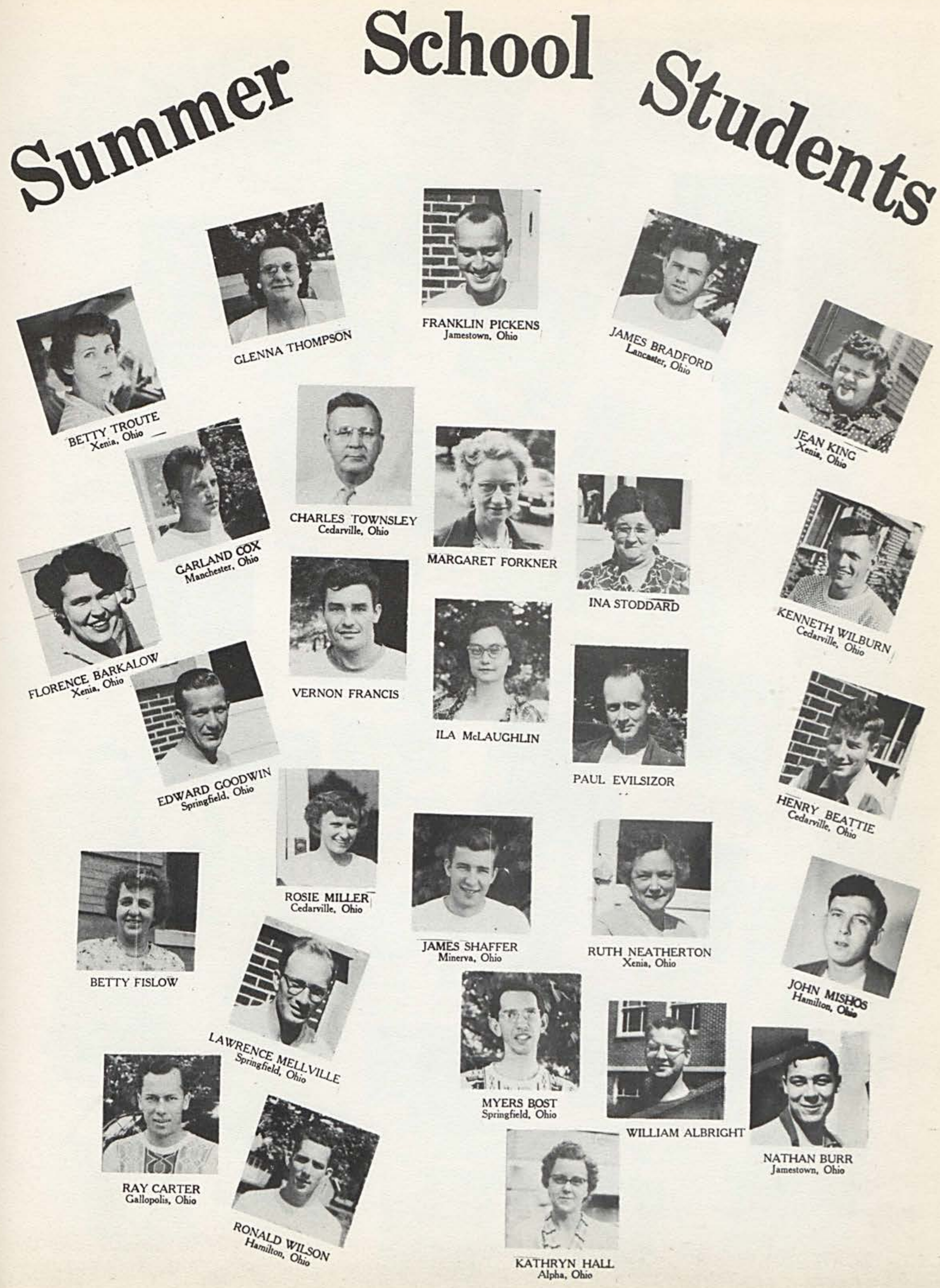



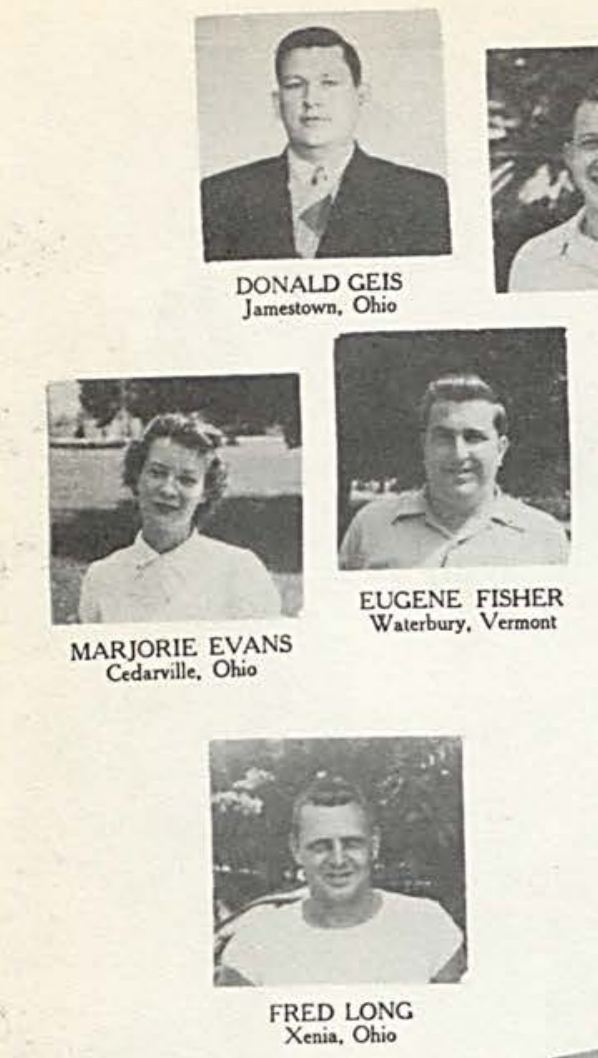

$$
\begin{aligned}
& \text { DAVID SPITZER } \\
& \text { Tipp City, Ohio }
\end{aligned}
$$
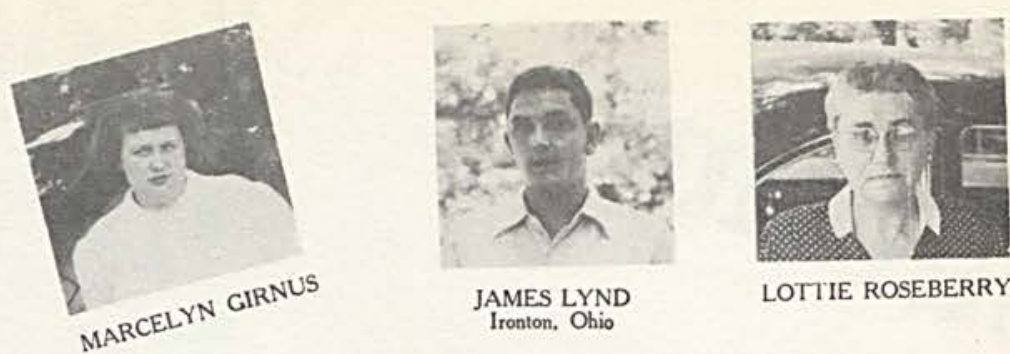

LOTTIE ROSEBERRY

JAMES LYND
Ironton, Ohio
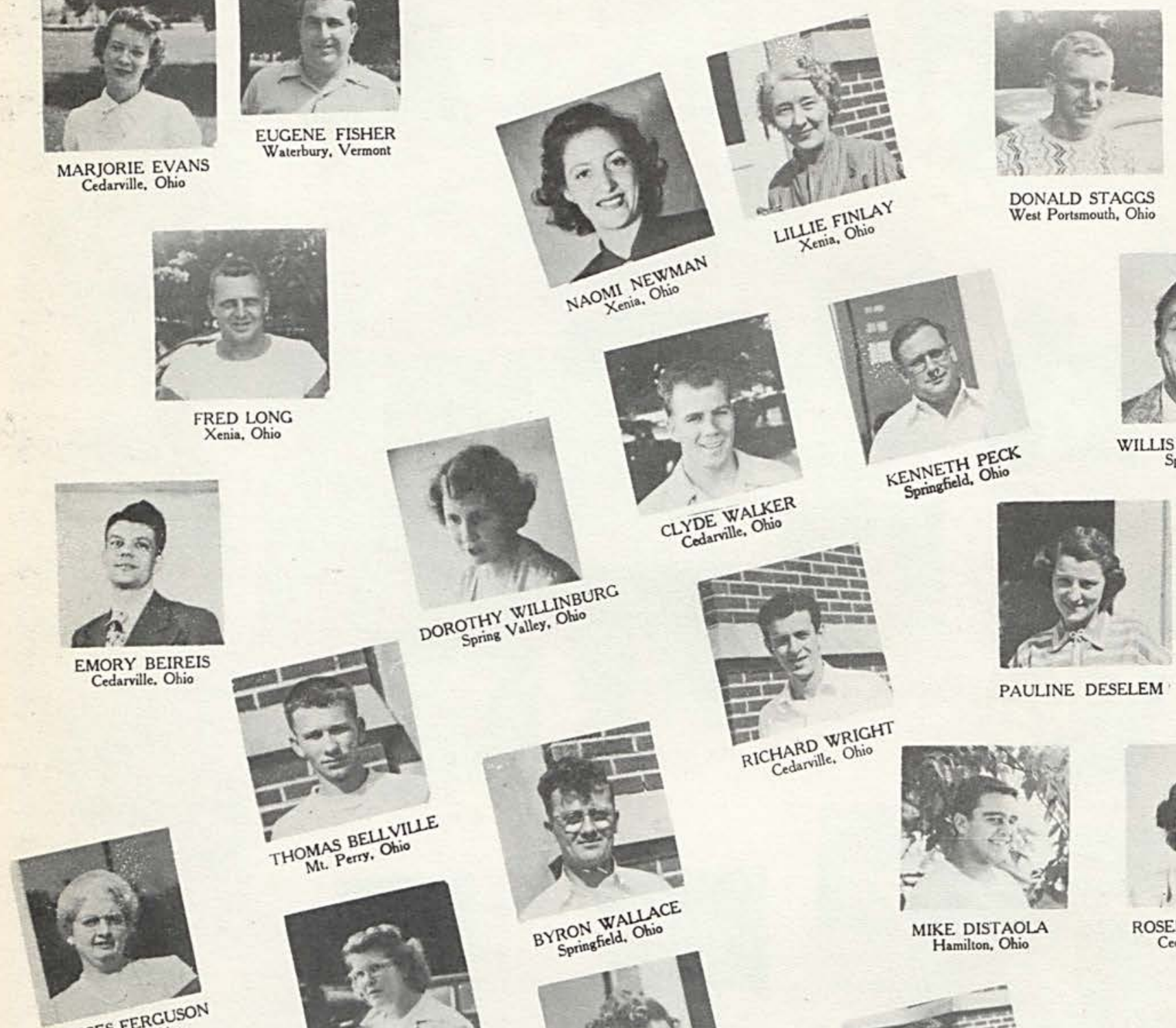

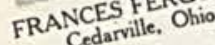
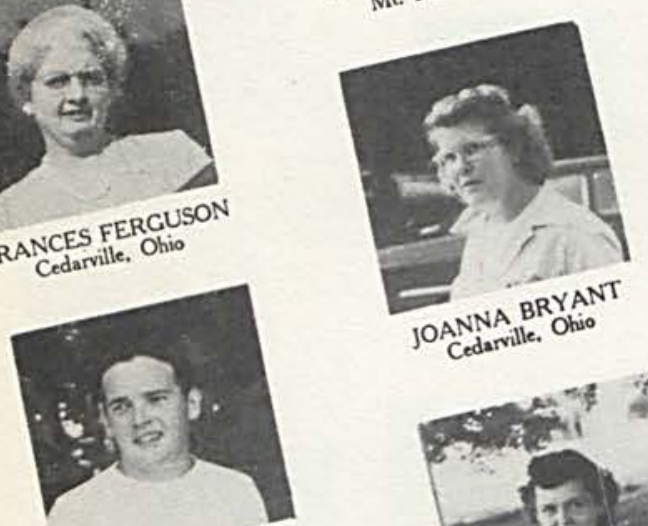

$$
\text { JAMES DILL }
$$
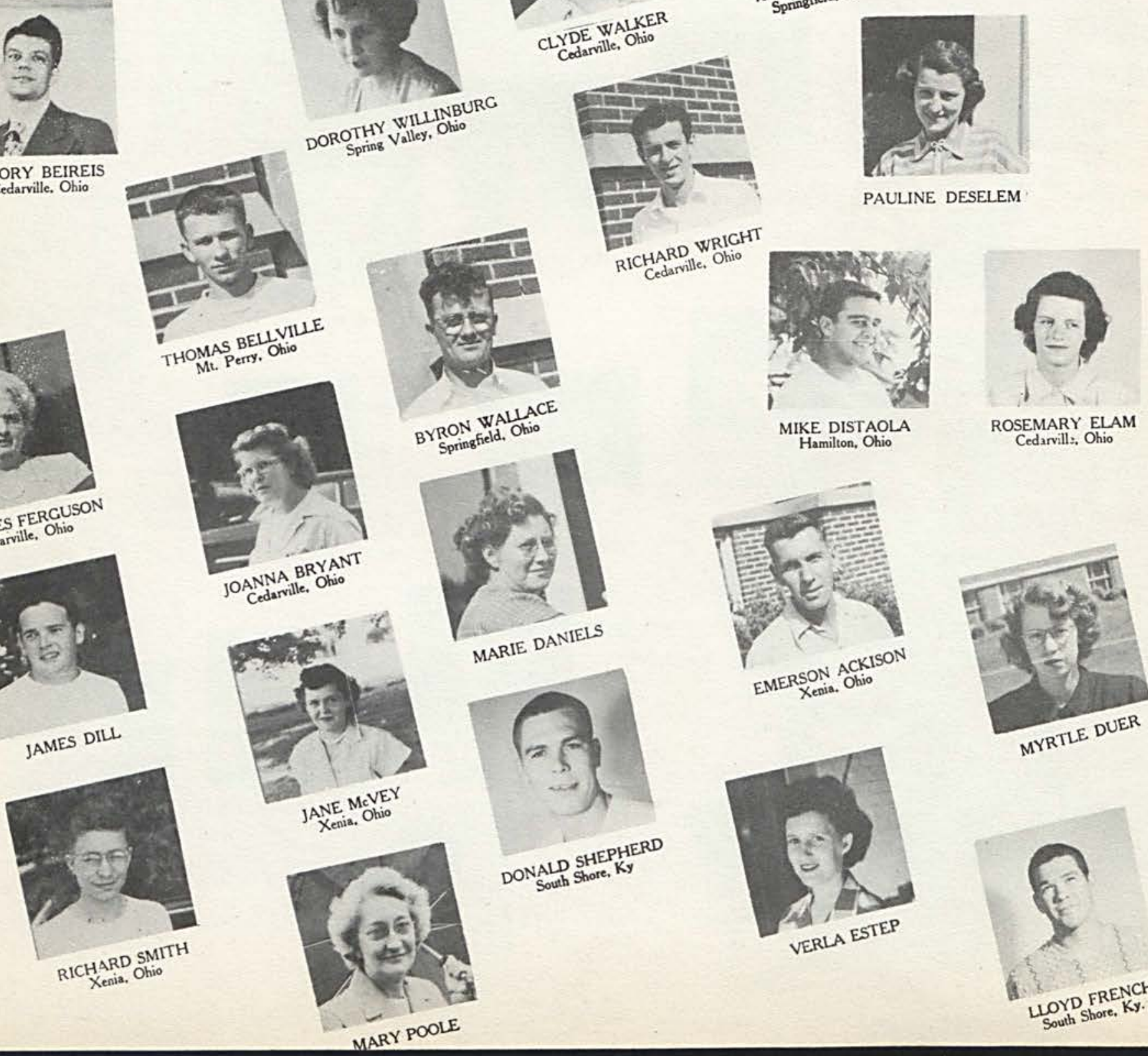

PAULINE DESELEM

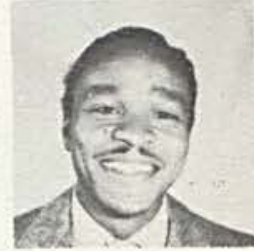

WILLIS HIFFINBOTHAM KENNETH PECK
Sprimgliedd, Ohio

Springfield, Ohio
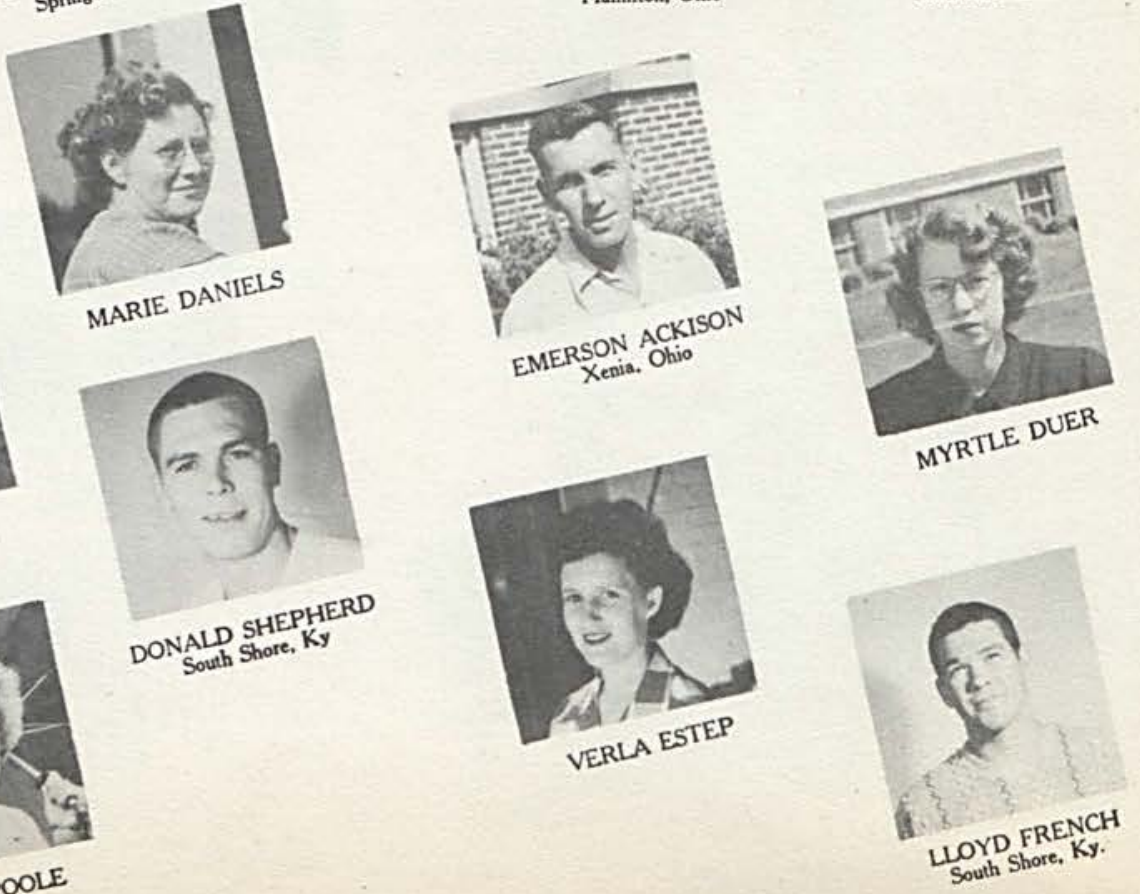


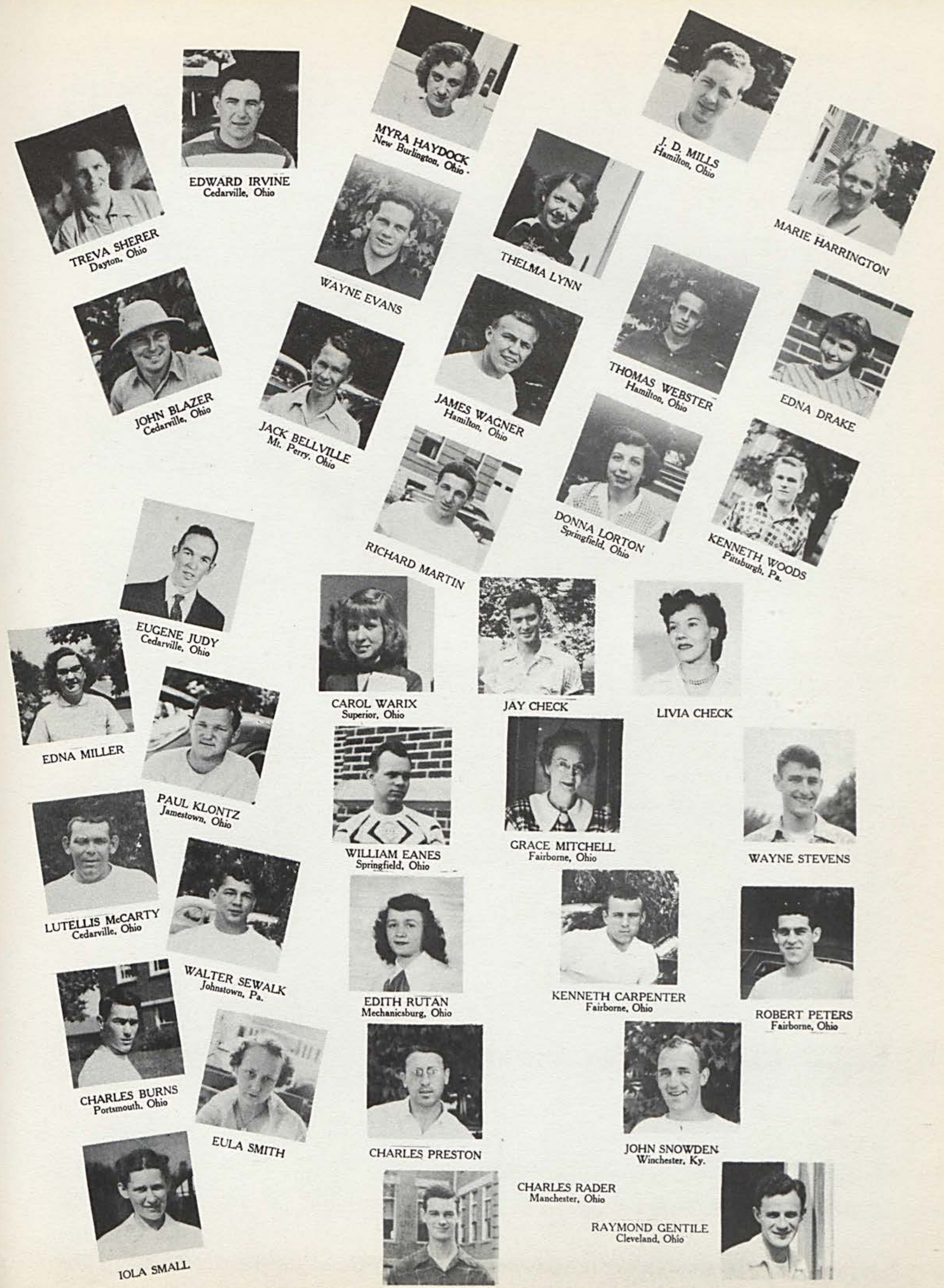



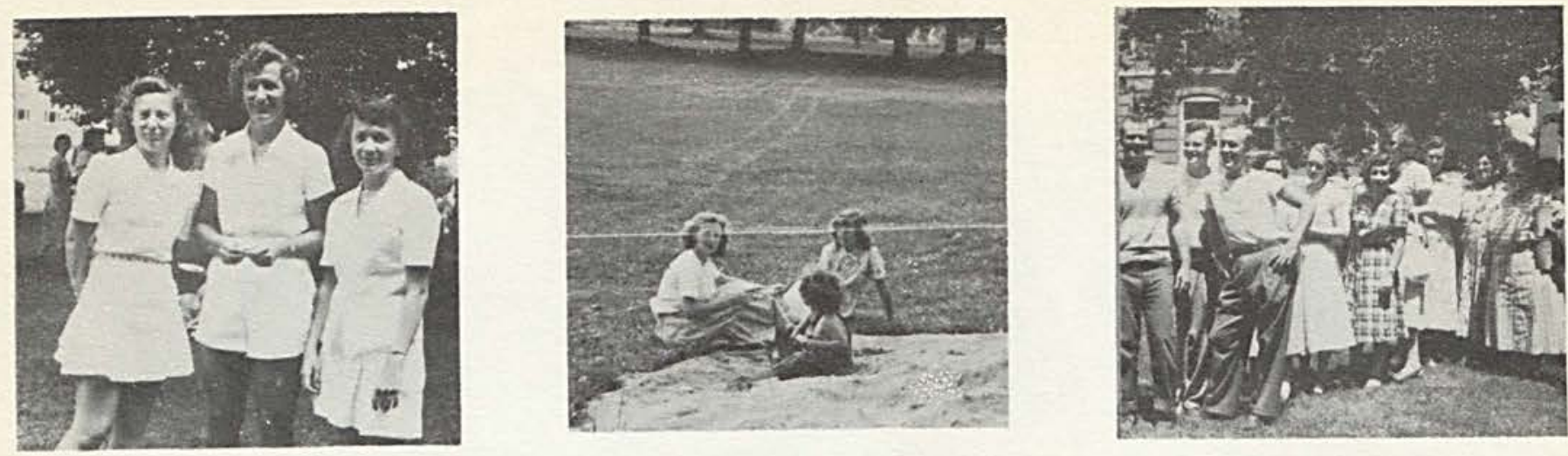

AT SUMMER SCHOOL PICNIC
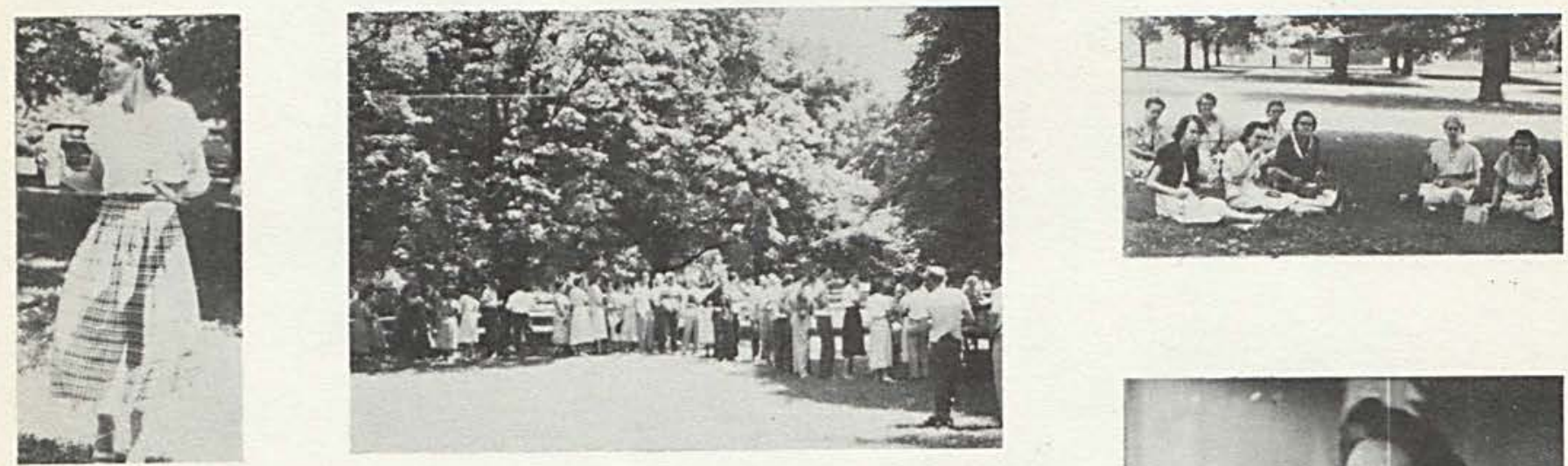

"SUNNING"
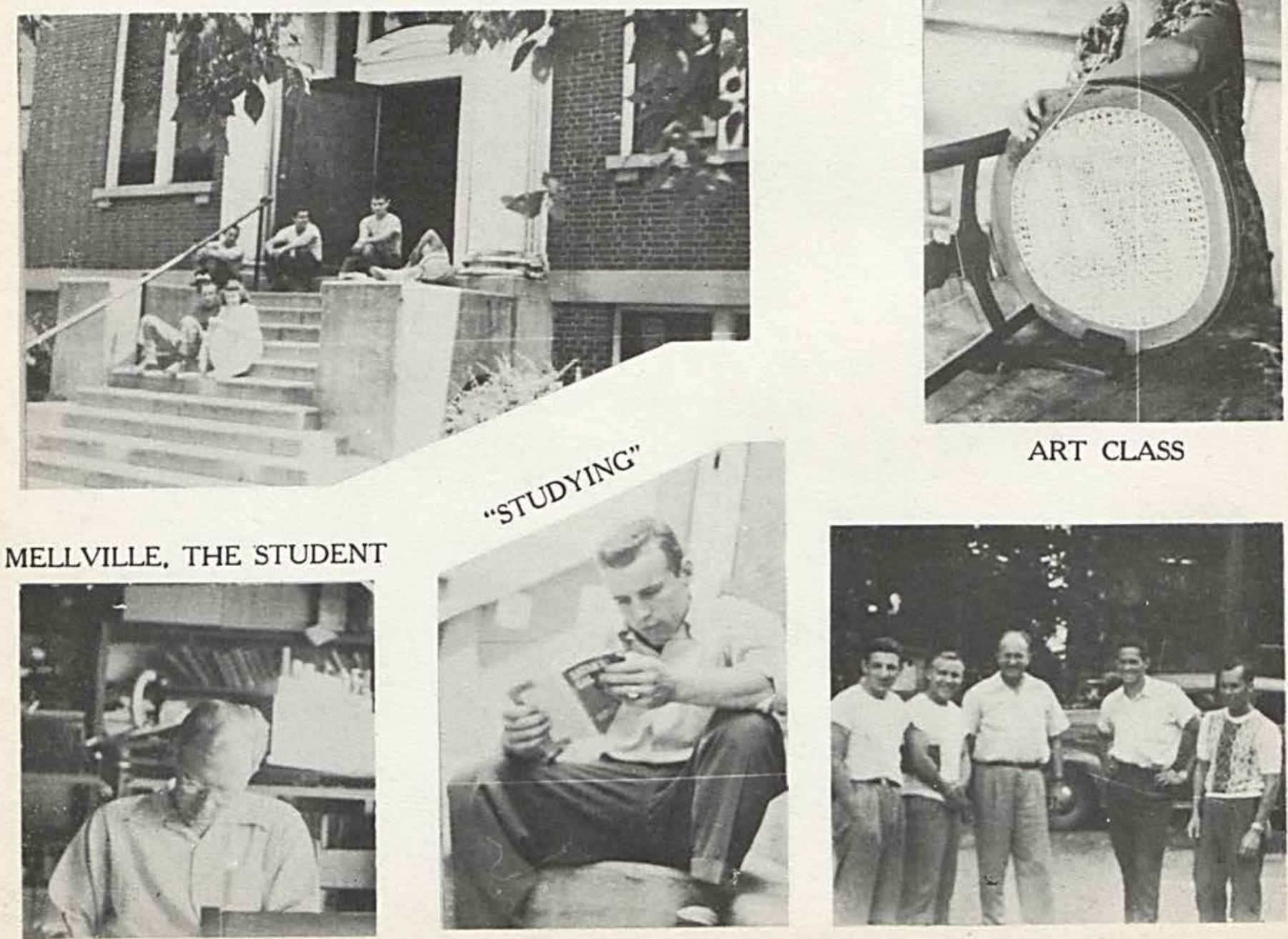


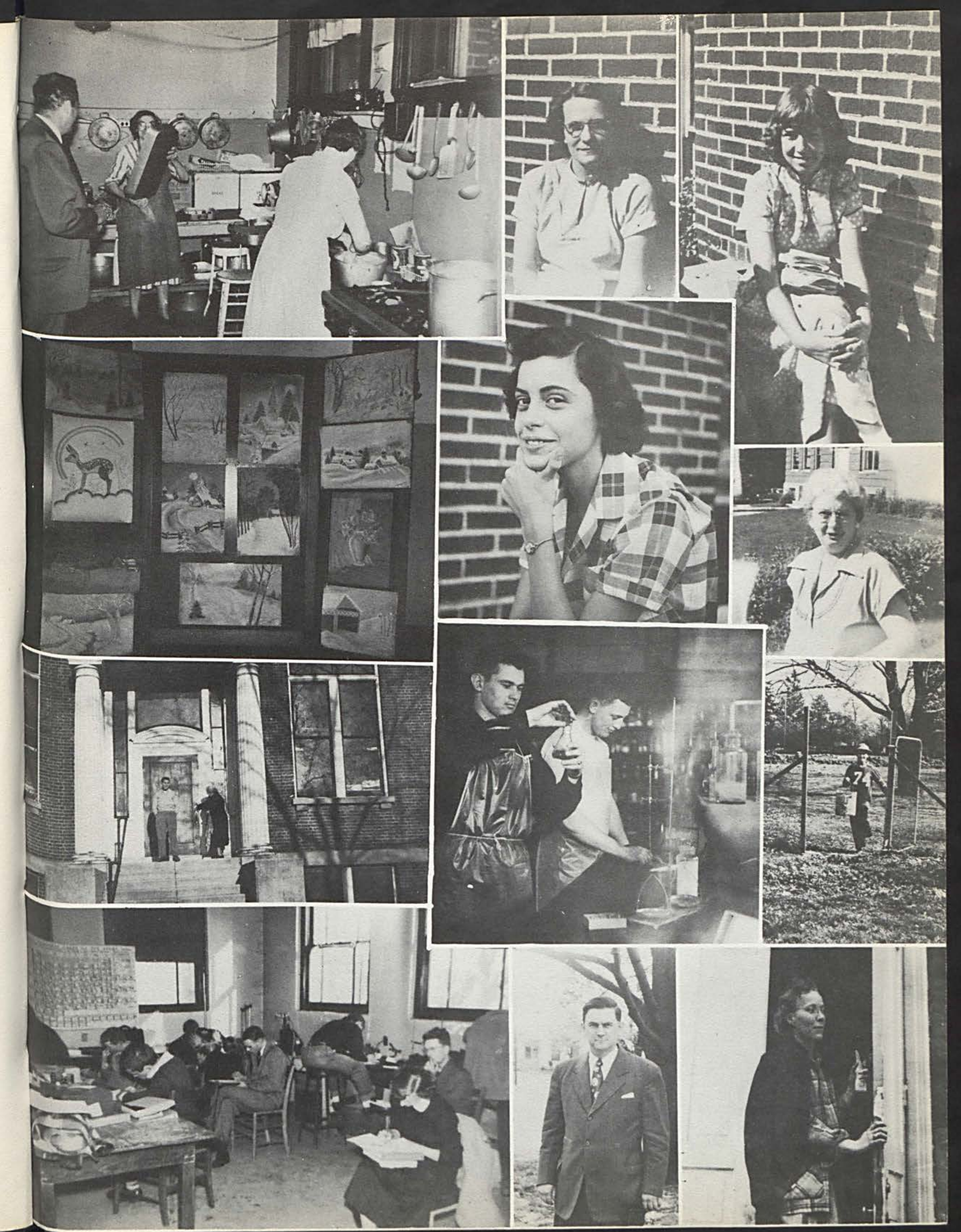




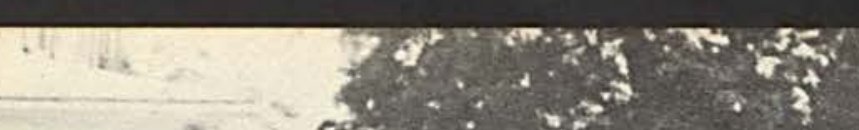
(1) (1) all 11 in ta

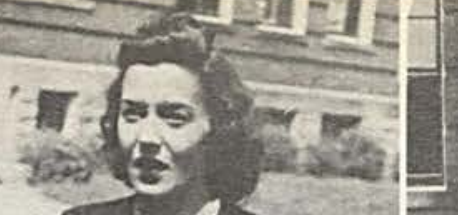
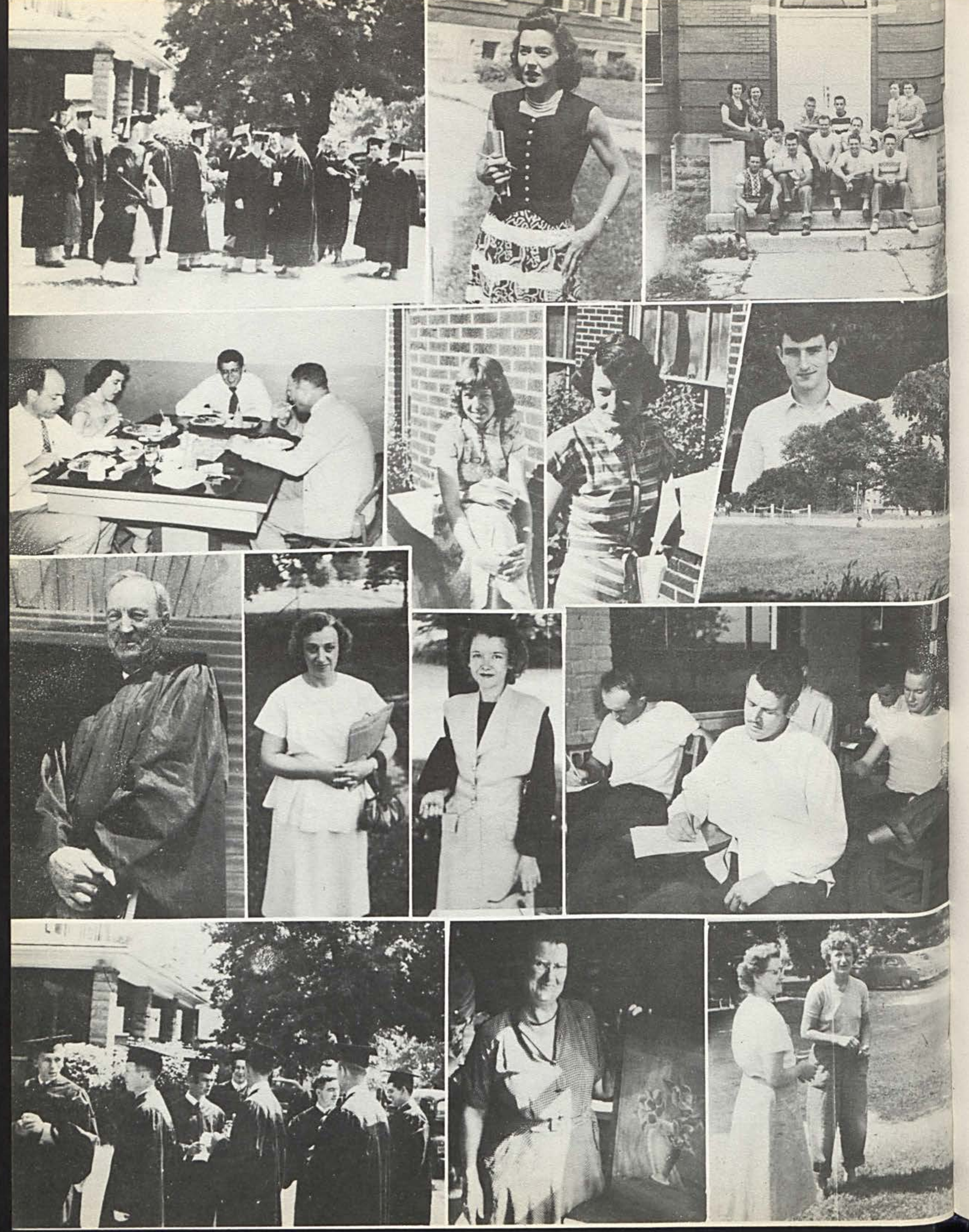


\section{Compliments of}

\section{THE}

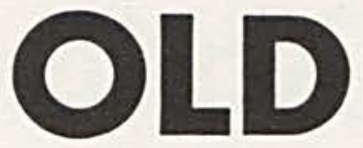

MILL

on Route 42

"Where Students Meet to Eat"

Compliments of

ADAIR

FURNITURE

STORE

Xenia, Ohio
Compliments of

HAMMAN'S

DAIRY

Cedarville, Ohio

We Sell Borden's Milk
U can stretch ur $\$$ by buying ur dry goods, clothing, shoes. and notions from us

Also the Best Auto Insurance and Quickest Service in Creene County

\section{Home Clothing Co.}

G. H. Hartman, Prop.
Compliments of

\section{The Cedarville Locker}

D. H. Reynolds

Cedarville, Ohio 


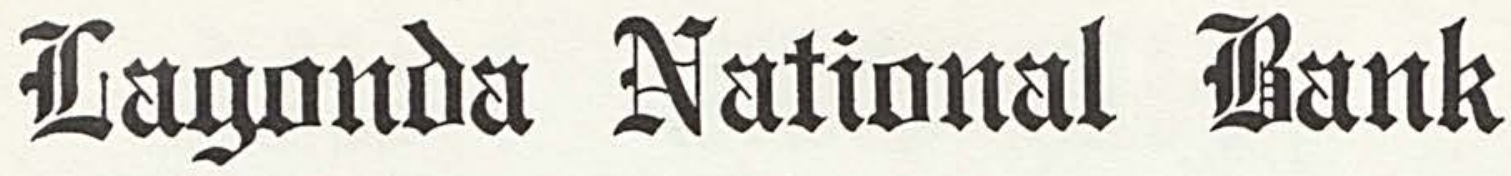

of Springfield, Ohio

\section{BRAUN'S Jewelers}

8 NORTH DETROIT STREET

XENIA, OHIO

\section{DIAMONDS - GEM COUNSELLORS \\ Longines - Wittnauer - Hamilton - Elgin WATCHES}

Gem Identification

Phone 1126

\section{CONGRATULATIONS}

Managing a small college is no eas: job in this day of inflation costs and war pressures. We congratulate the trustees and officers of Cedarville College for keeping up such high scholastic standards in spite of economic pressures which have been particularly strong on small colleges.

We believe that the tradition and past accomplishments of sending out more than your share of students to become illustrous citizens will continue.

\section{The Miami Deposit Bank} CEDARVILLE, OHIO

Member F. D. I. C.

\section{VALENTINE \\ SHOE REPAIR - HAT CLEANING SHINING PARLOR}

\section{ALL WORK GUARANTEED}

Phone 4-1297

10 North Fountain Springfield
XENIA AVENUE

\section{CUMMINGS CHEVROLET}

SALES and SERVICE

Body and Fender Repairing

Phone: 6-2701 


\section{ANDERSON \\ INSURANCE \\ A GENCY}

Competent and Complete Insurance Service

XENIA, OHIO

\section{COMPLIMENTS \\ of \\ MR. FRANK HARDT}

448 HOLT STREET

DAYTON 7, OHIO

\title{
Compliments of
}

\section{C. BREWER Cedarville, Ohio}

\author{
Heating \\ is our \\ Specialty
}


Greetings

TO THE

CLASS

of

1951

of

Cedarville

College

from

Acme Electric Company

500 East High Street

Springfield, Ohio

Phone 2-6789

Harold South

Harry McCurdy 


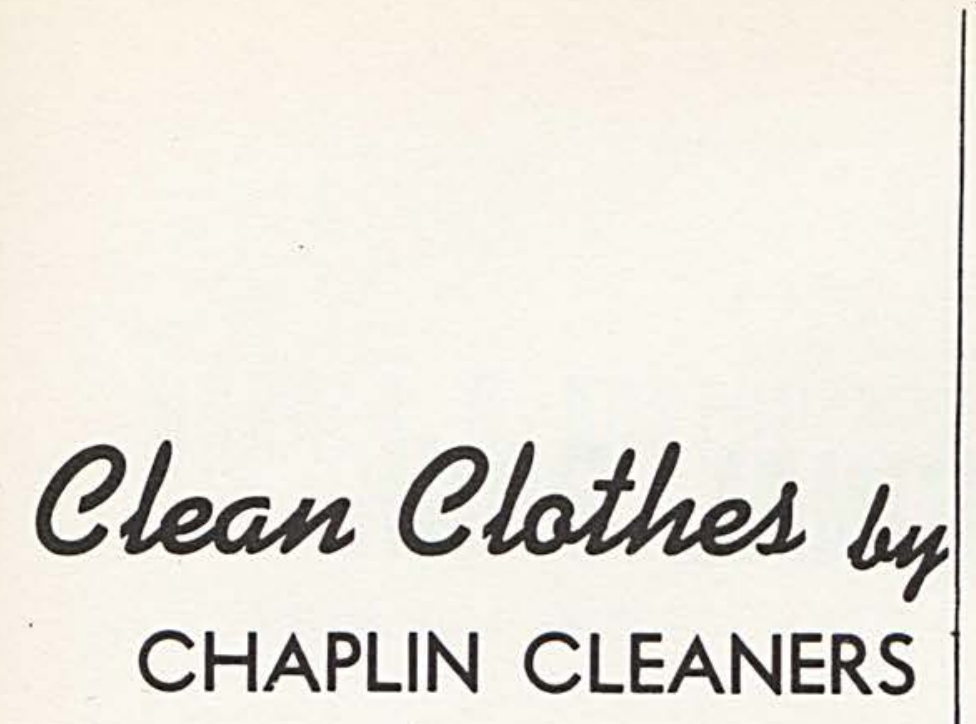

CEDARVILLE, OHIO

\section{CENTRAL MIXED CONCRETE BUILDING MATERIALS COAL \\ WHOLESALE - RETAIL}

The Beckley \& Myers Co. SPRINGFIELD, OHIO

603 E. HIGH ST.

\section{Moore's Greenhouse}

A Distinctive Arrangement
For Every Floral Need
M. M. MOORE, Florist
Jeffersonville Pike Jamestown 4-3311
COMPLIMENTS
of
John Sexton Company
- Wholesale Grocers -
chicAco, ILLINOIS

\section{COMPLIMENTS \\ of}

A FRIEND 


\title{
XENIA NATIONAL BANK
}

\author{
1835 - Over a Century of Service - 1951 \\ CAPITAL FUNDS, $\$ 620,000$
}
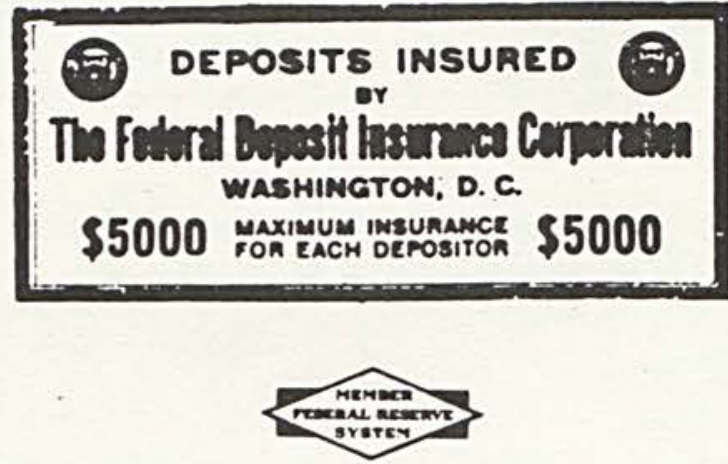

You are never a stranger after your first visit to our bank 


\section{HARIER \& HUSTON}

CEDAR VILLE MARKET

It Pleases Us To Please You

MEATS VEGETABLES GROCERIES
SPORTING GOODS

TELEVISION

\section{Famous Auto} Supply Co.

Xenia, Ohio

\section{AUTO SUPPLIES}

23 W. Main

\section{JAMES \\ DRUG \\ CO.}

McClellan Hatchery \& Feed Center

THE BEST OF CHICKS

THE BEST OF FEEDS

XENIA. OHIO

Phone 6-1771

Cedarville, Ohio

COLLEGE AND OFFICE SUPPLIES

PHOTOGRAPHIC SUPPLIES

PHOTO FINISHING

THE REXALL STORE

PHOTO FINISHING 


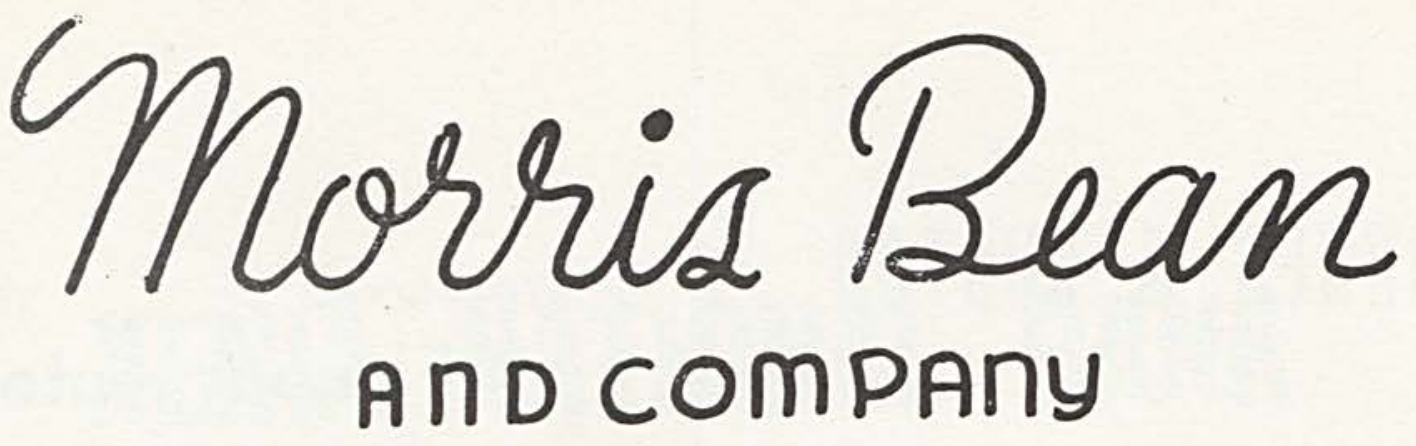

YELLOW SPRINGS, OHIO

MANUFACTURERS OF

ALUMINUM CASTINGS

FOR

TIREMOLDS AIRCRAFT

and many other purposes

\section{XENIA ABATTOIR}

WHOLESALE MEATS

BEEF, PORK, VEAL, SMOKED MEATS, LARD Birch Road

R. R. \#2, XENIA, OHIO

Phone 339
CHEVROLET

OLDSMOBILE

LAnG'S

SALE AND SERVICE

Used Cars and Trucks

Phone No. 872

Xenia. Ohio 
After graduation... wherever you go... whatever you do... you'll always find Coca-Cola ... your companion of so many never-to-be-forgotten times. Coke belongs with happy moments and friendly living.

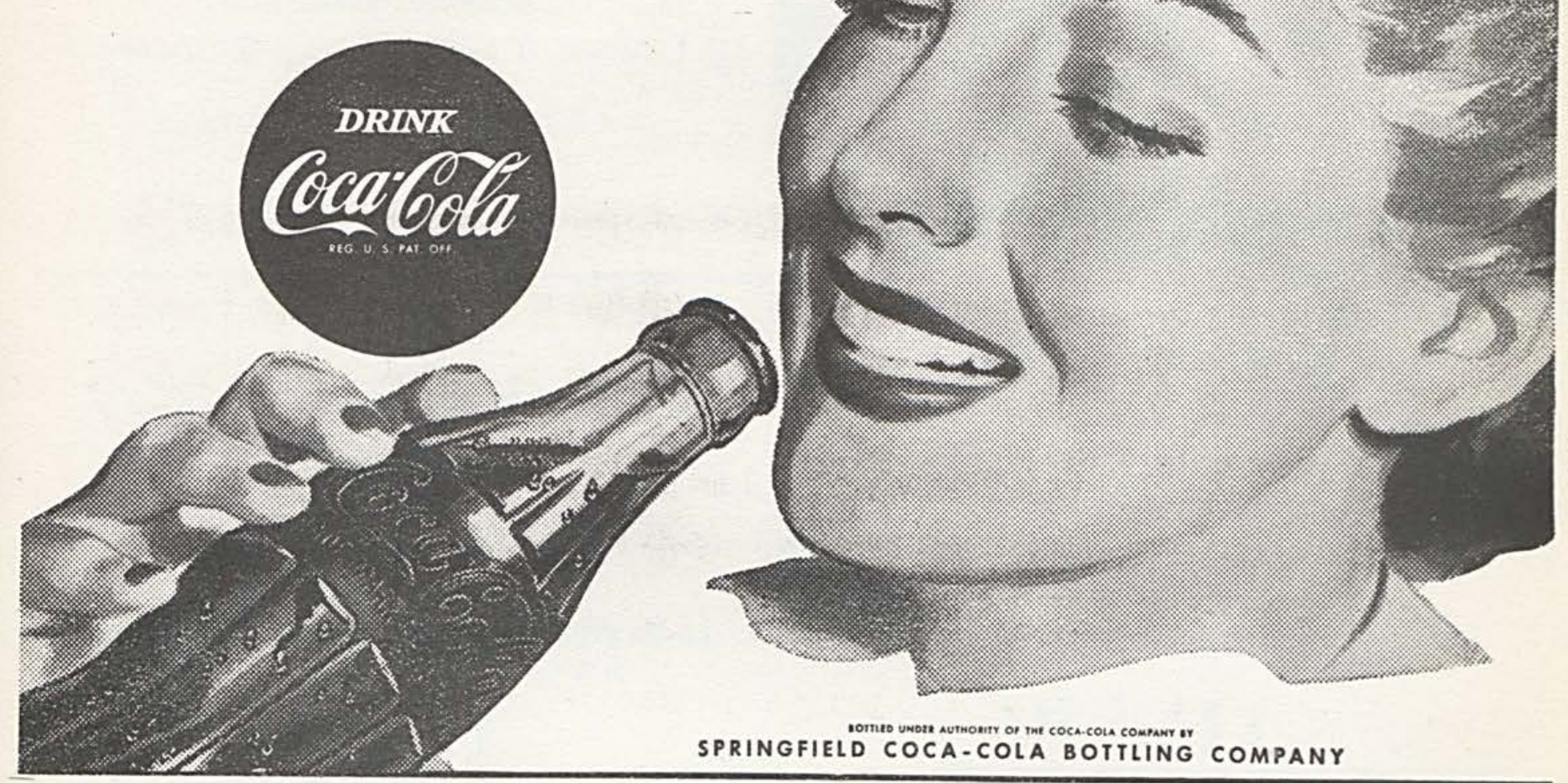

Quality Clothes Since 1887

\section{The Criterion \\ WHERE GENTLEMEN BUY}

28 SOUTH DETROIT ST.

XENIA, OHIO

Telephone 586

\section{THE}

CEDARVILLE

\section{HERALD}

Cedarville's Oldest Insti'ution
* Films

* Cameras

* Darkroom Supplies

COMMERCIAL \& PORTRAIT PHOTOGRAPHY

\section{Creswell Camera Store}

XENIA AVENUE

CEDARVILLE, OHIO 
For All Your Photographic Needs

\section{FORD}

SALES and SERVICE

105 E. MARKET ST.

Phone 488
XENIA, OHIO

\section{McCorkell Insurance Agency}

For All Your Insurance Needs

Cedarville, Ohio

Phones: 6-2141-6-1881
CHETLOE'S

DRY CLEANING

Opposite Post Office

Yellow Springs

Compliments of

Hilltop Service Station

Cedarville, Ohio

SUNOCO GAS AND OILS

\section{PICKERING} E L E C T R I C

CONTRACTOR and DEALER

WESTINGHOUSE APPLIANCES

SUNBEAM APPLIANCES

EASY WASHERS

HOOVER CLEANERS

PHILCO TELEVISION AND RADIO

SALES and SERVICE

Cedarville, Ohio 


\section{CONFAR'S PANTRY}

CEDARVILLE, OHIO

Phone 6-2773

STUDENT HEADQUARTERS

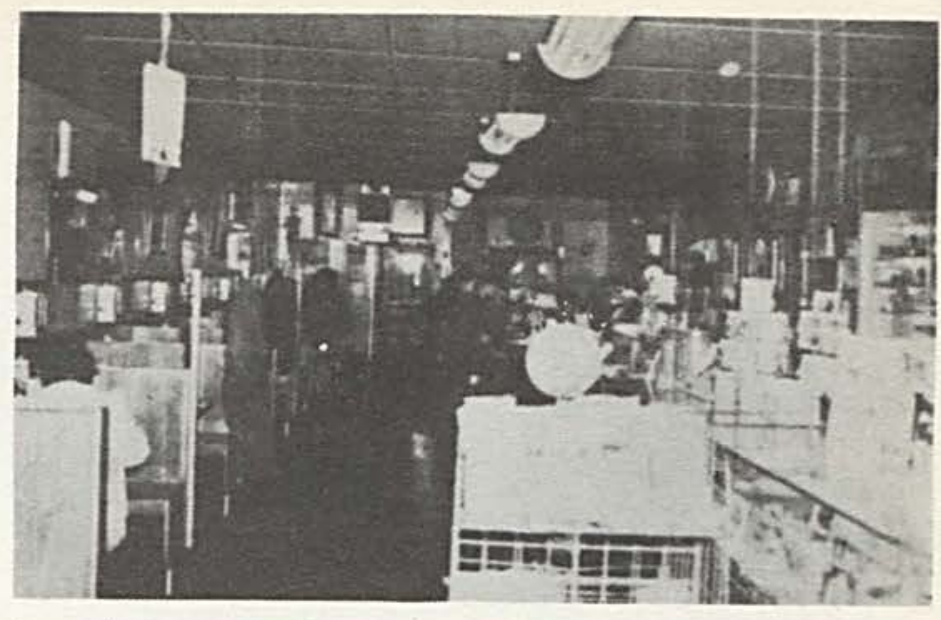

Compliments of

PITTSBURGH

PAINT

and

PITTSBURGH

PLATE GLASS

Compliments of

DUVALL

HARDWARE

Cedarville, Ohio

Phone: 6-1941

\section{THE \\ STOKES MOTOR CO.}

S. Main St. Cedarville, Ohio

Phone: 6-4021
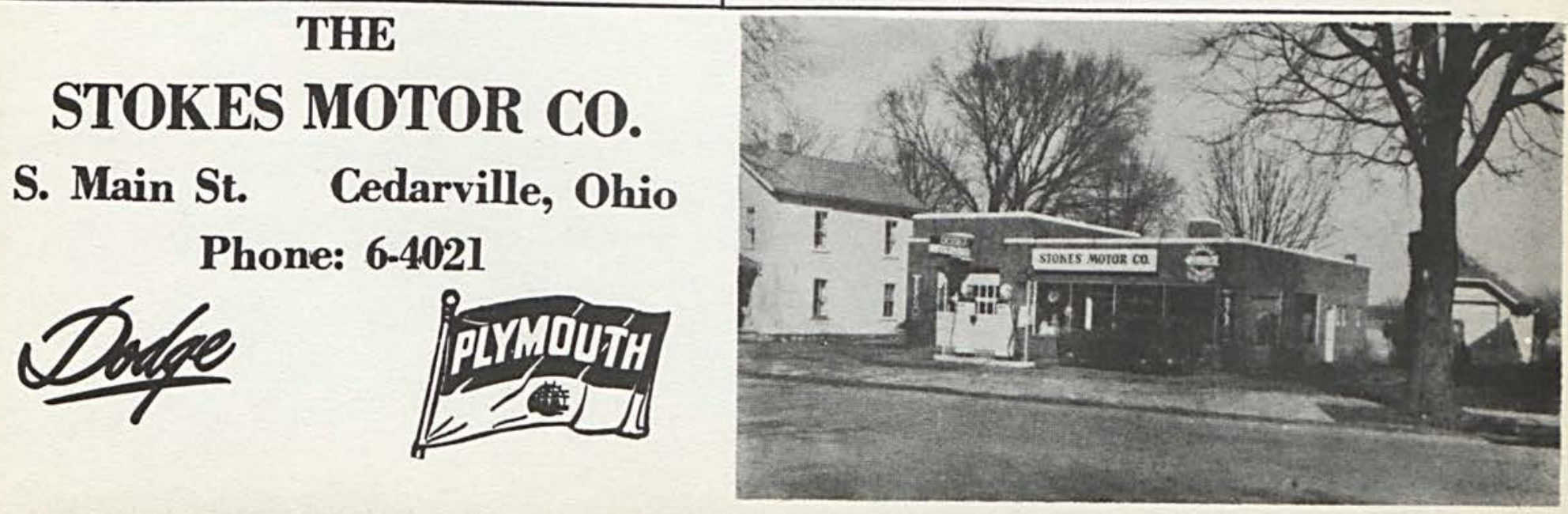
AUTOGRAPHS 
AUTOGRAPHS 
AUTOGRAPHS 



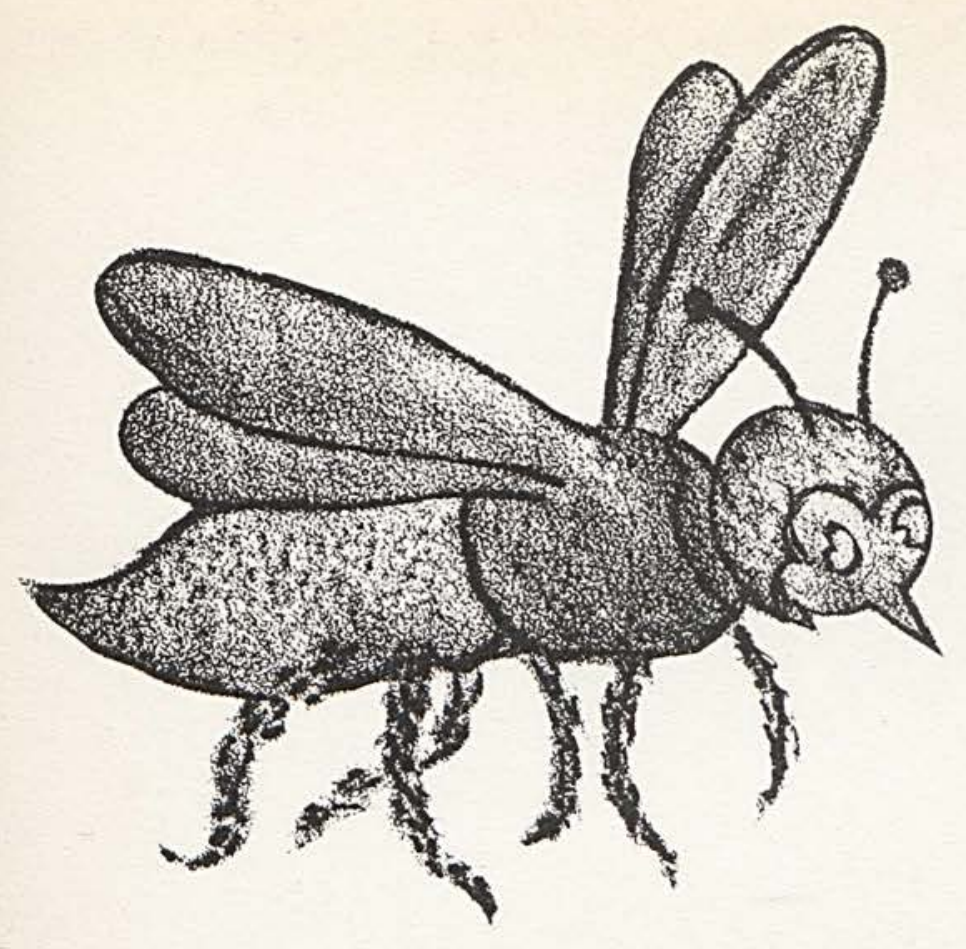

\section{GRIDLATIOI SIPPIENEVT To The 1951 (GWBRIS}




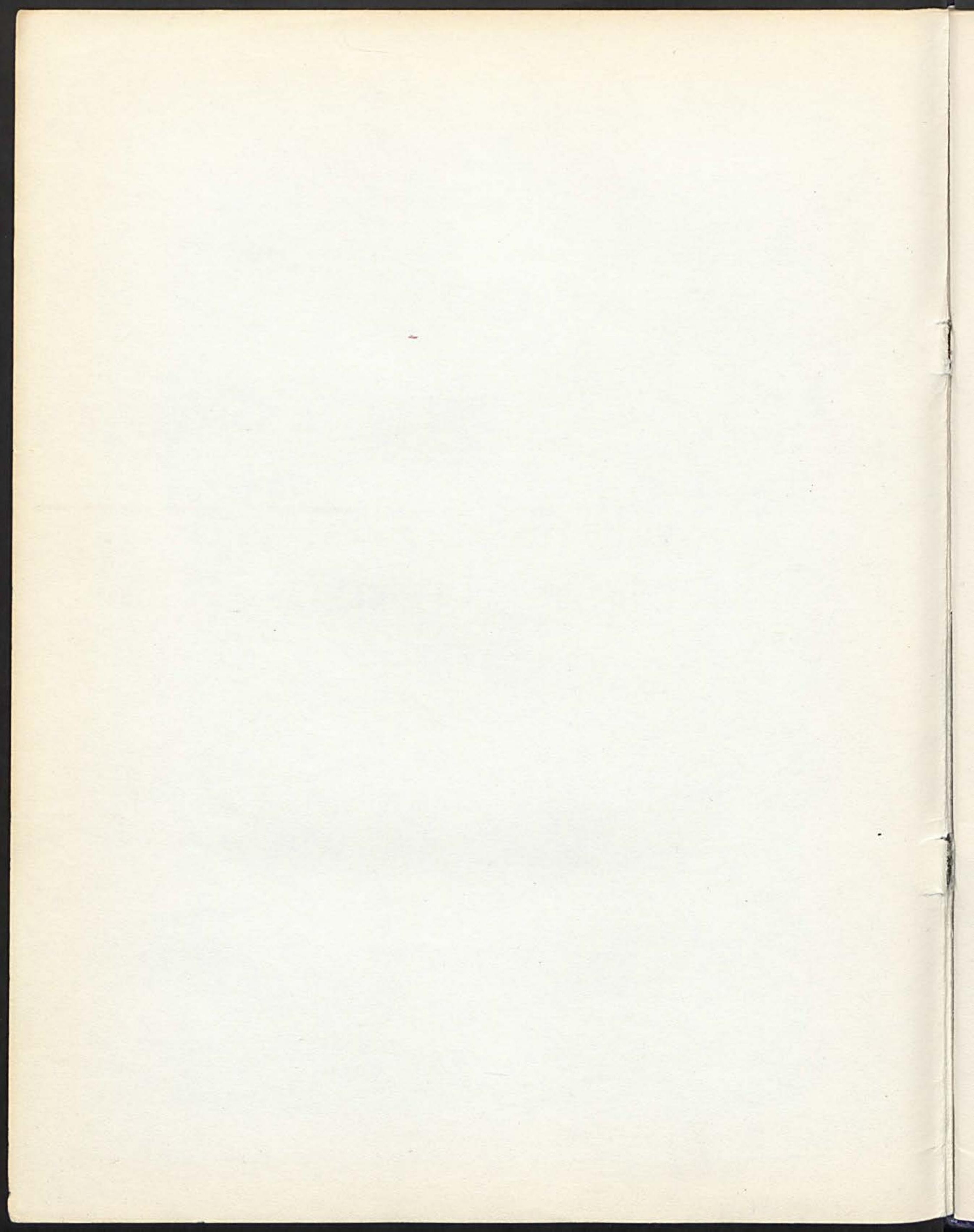




\section{Graduates of 1951}

The graduating class of 1951 leaves behind it a four-year record of steadfast, earnest preparation to meet the obstacles which it will be confronted with in its future actirities. It was this steadfastness and earnestness which made the Class of 1951 an essential part of Cedarville College.

As the gradutes embarked they left with us their profound philosophy: "Ours is the hope that we have left at Cedarville College a high standard which those who follow will make part of themselves and will strive to improve as they progress."

Richard Humble receives Scholarship Award

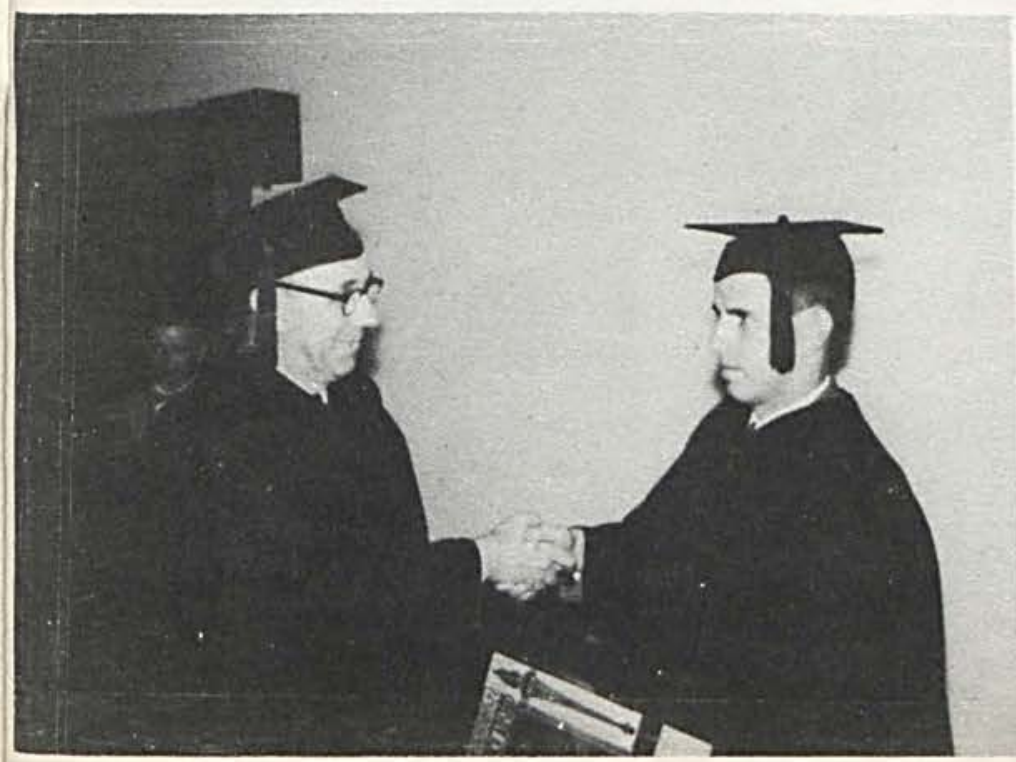

Jack Bellville receives President's Trophy

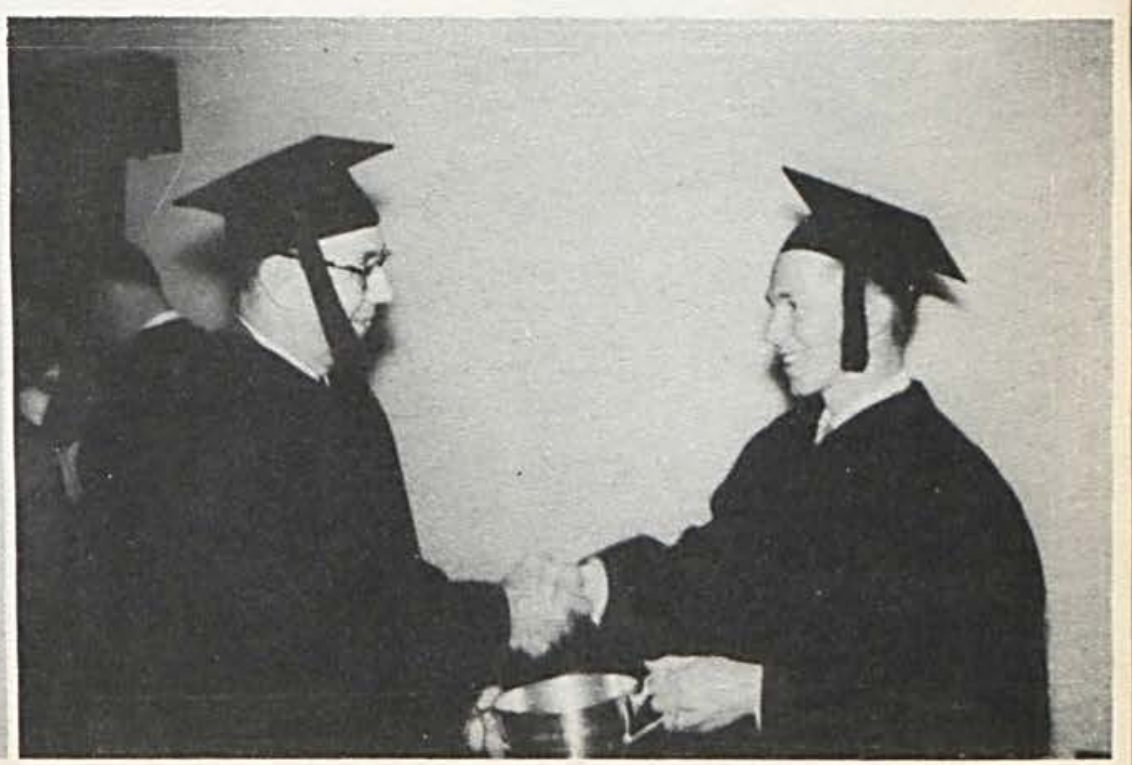




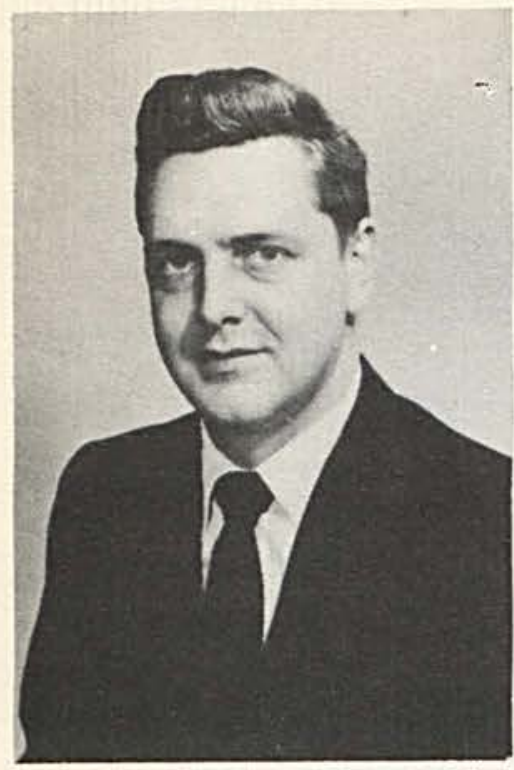

FREDERICK R. LONG,

cum laude

Xenia, Ohio

B.S. in Education

Senior Class President

Student Council President

Chi Mu Delta
FORREST W. STEPHENS, magna cum laude

Portsmouth, Ohio

B.S. in Education Crown Club Kappa Sigma Kappa
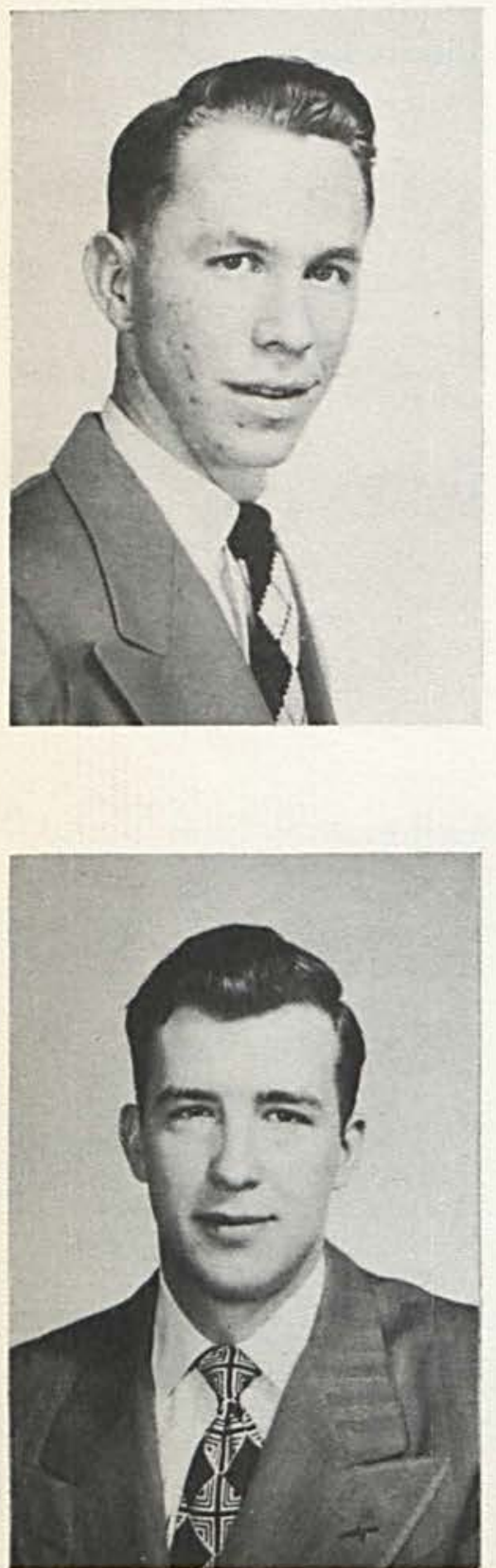

FRANK W. ZIRBEL, JR. Forest Junction, Wisconsin B.S. in Education Basketball Whispering Cedars Editor Kappa Sigma Kappa

JAMES M. SHAFFER Minerva, Ohio

A.B.

Senior Class Secretary-Treasurer

Cedrus Editor

Kappa Sigma Kappa
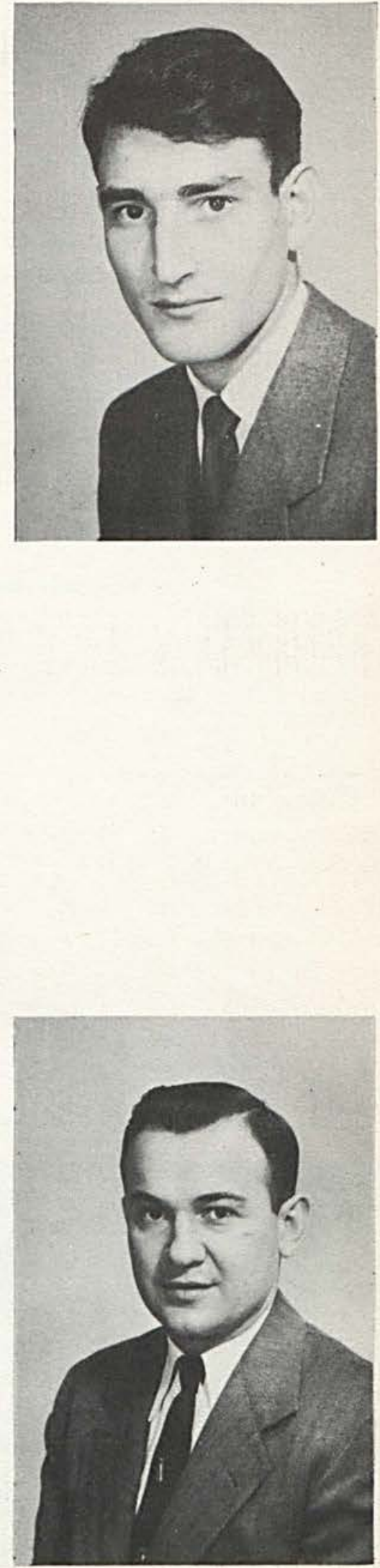

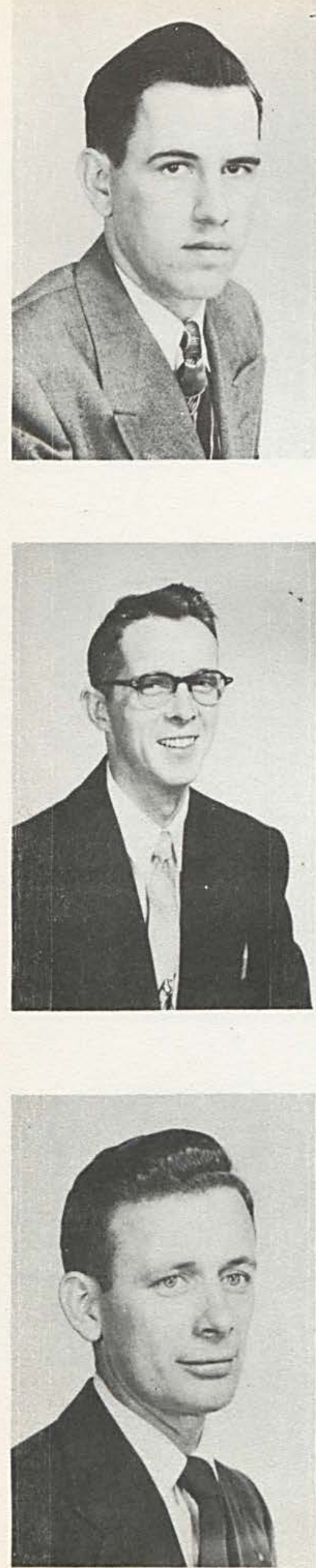

RICHARD HUMBLE, cum laude

Urbana, Ohio

Scholarship Trophy

THOMAS S. BELLVILLE, cum laude B.S. in Education Kappa Sigma Kappa

\section{WILLIAM PURDOM}

Cedarville, Ohio

B.S. in Education

Chi Mu Delta

WILLIAM R. OSMAN, magna cum laude

Paso Robles, California

B.S. and B.S, in Education

Crown Club

Kappa Sigma Kappa

BYRON J. AMES New Burlington, Ohio B.S. in Education Chi Mu Dello Mount Perry, Ohio
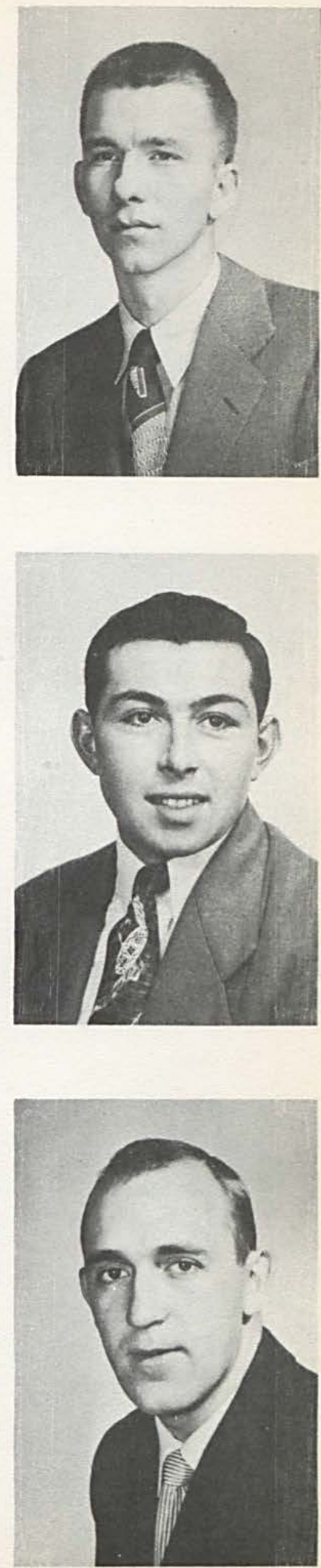

JOHN A. SNOWDEN, JR. Winchester, Kentucky B.S. in Education Cedrus Assistant Editor Football Chi Mu Dello 


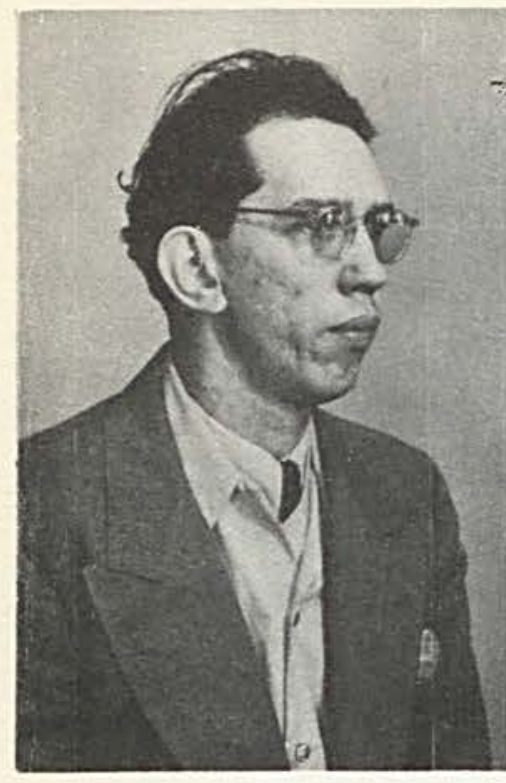

MYERS F. BOST

Springfield, Ohio

A.B.

Y.M.C.A.

\author{
LUTELLIS R. McCARTY \\ Cedarville, Ohio \\ B.S. in Education \\ Football \\ Zeta Sigma
}

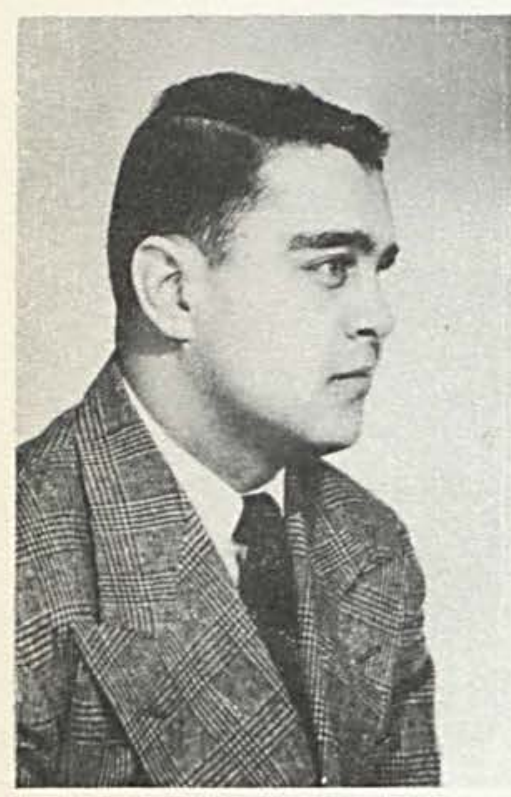

MICHAEL A. DiSTAOLA

Hamilton, Ohio

B.S. in Education

Basketball -Football

Chi Mu Delta

PETER G. THEOBOLD, JR.

Hamilton, Ohio

B.S. in Education

Football

Chi Mu Delta
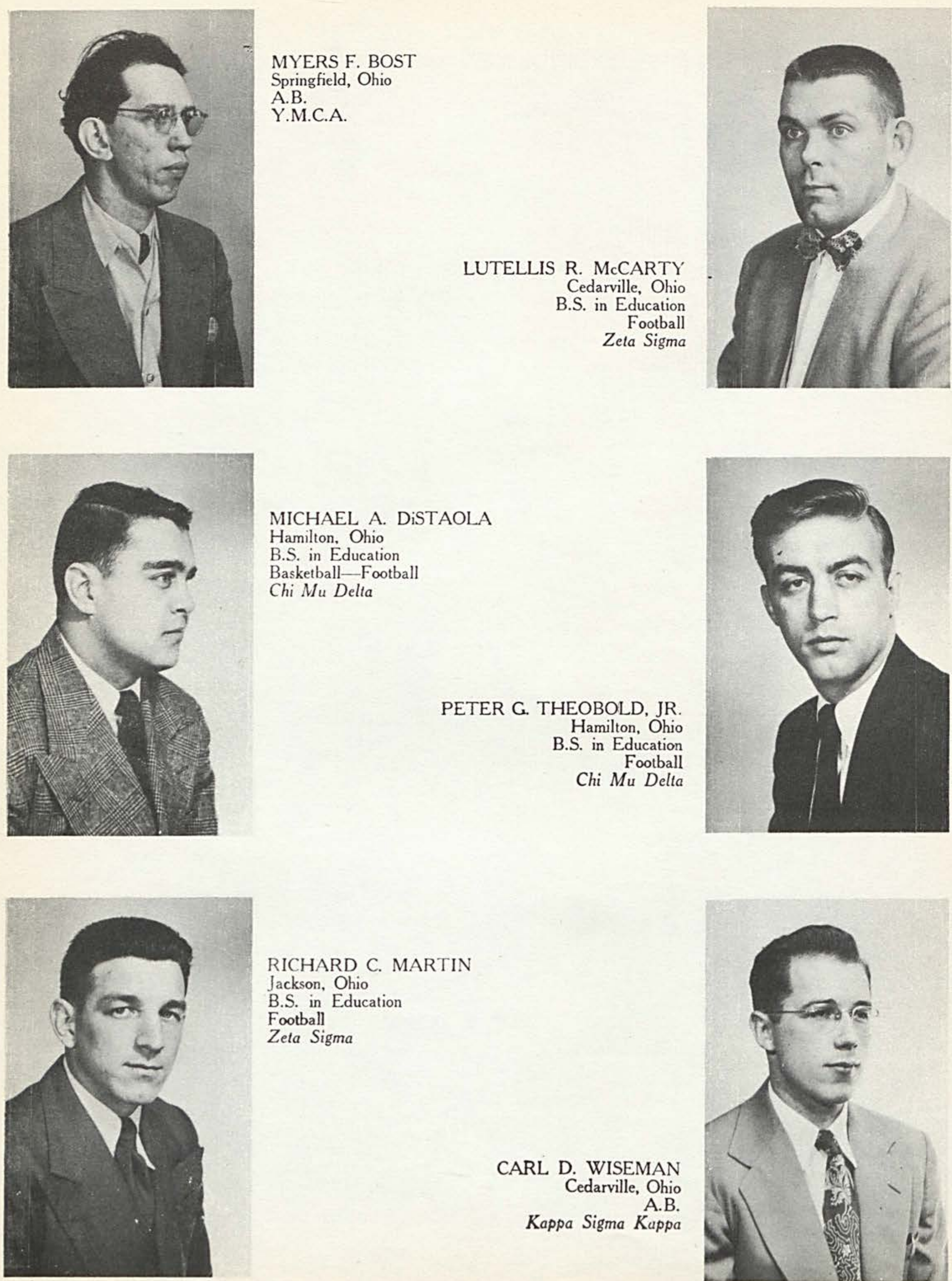

RICHARD C. MARTIN

Jackson, Ohio

B.S. in Education

Football

Zeta Sigma

CARL D. WISEMAN

Cedarville, Ohio

Kappa Sigma Kappa
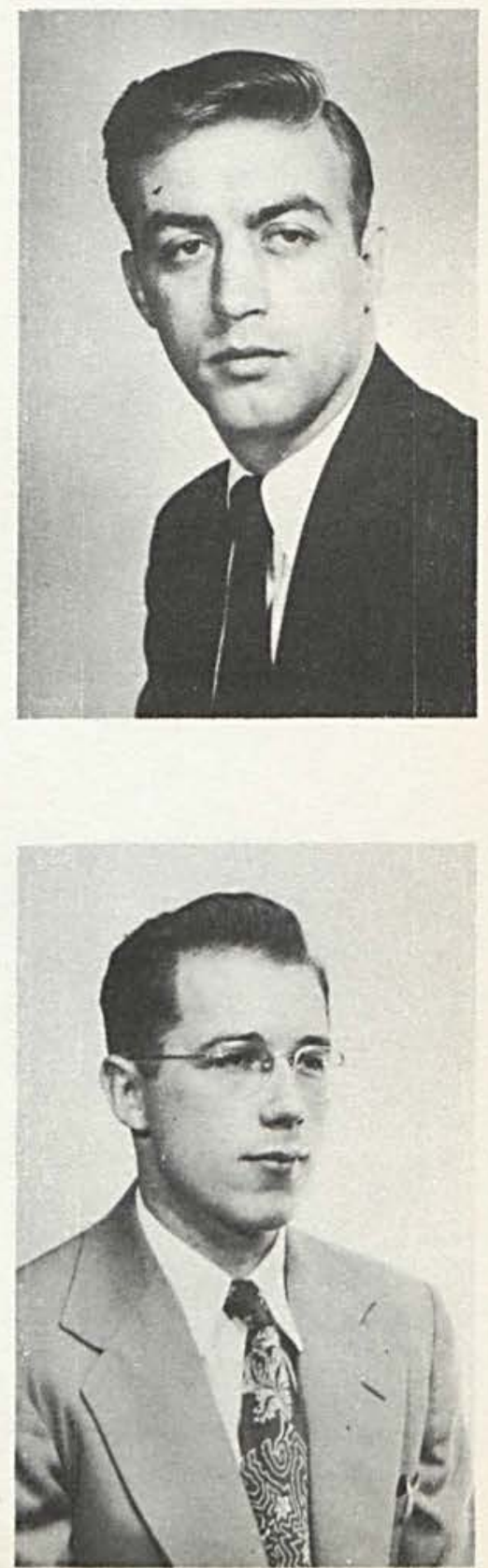

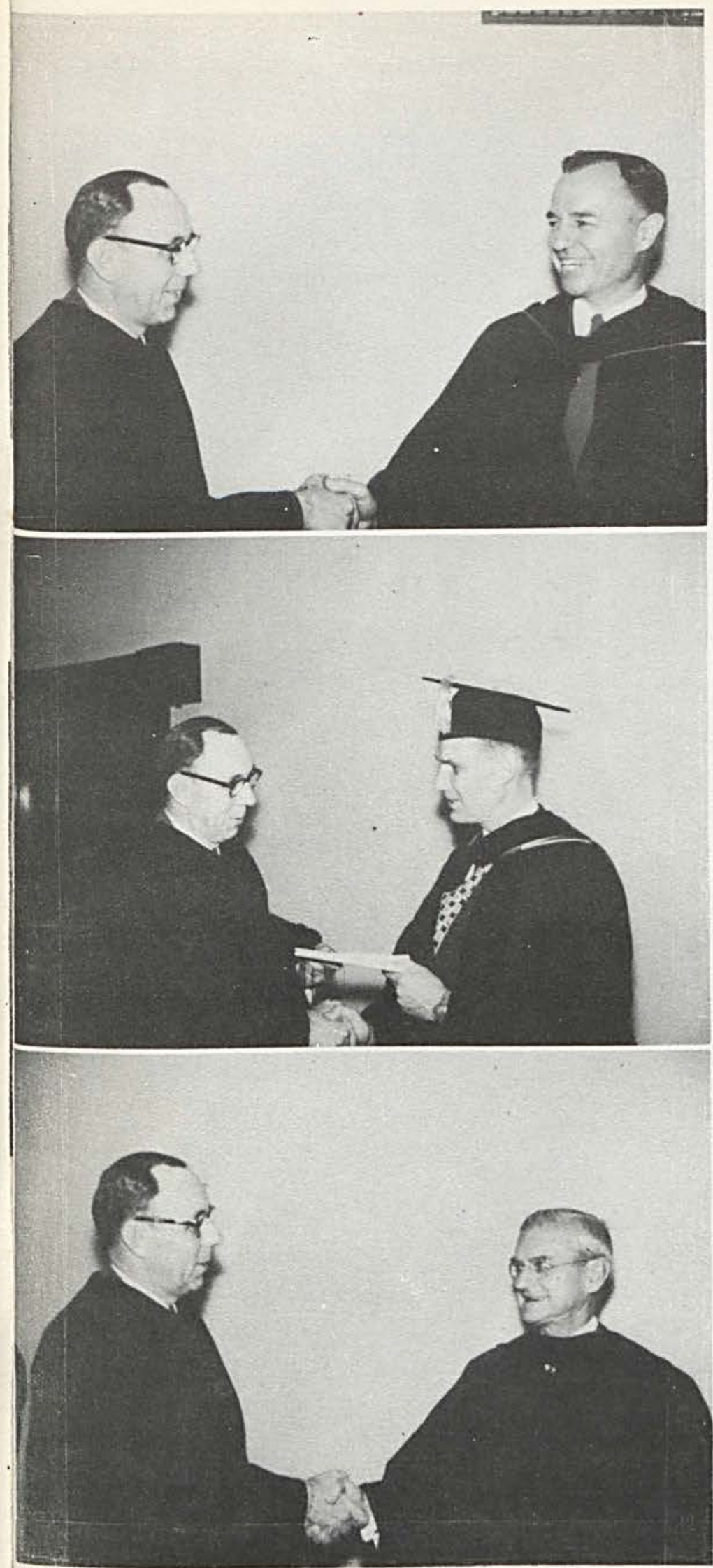

CONFERRING OF HONORARY DEGREES

CHARLES P. TAFT, LLD

SAMUEL D. MARBLE, LLD

CHARLES R. HOOK, LLD

\section{CHARLES}

W. RADER

Manchester, Ohio

B.S. in Education

Kappa Sigma

Kappa

HENRY W.

BEATTIE

Cedarville, Ohio

B.S. in Education

Football-

Basketball

Kappa Sigma

Kappa

RAYMOND

R. GENTILE

Cleveland

Heights, Ohio

B.S. in Education

Chi Mu Delta
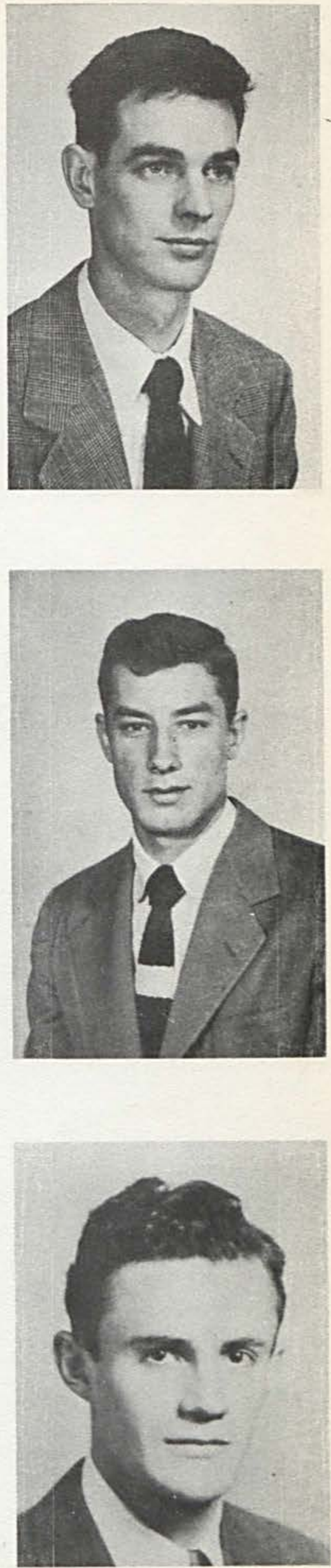

MRS. W. B. COLLIER

DONALD NOCK 

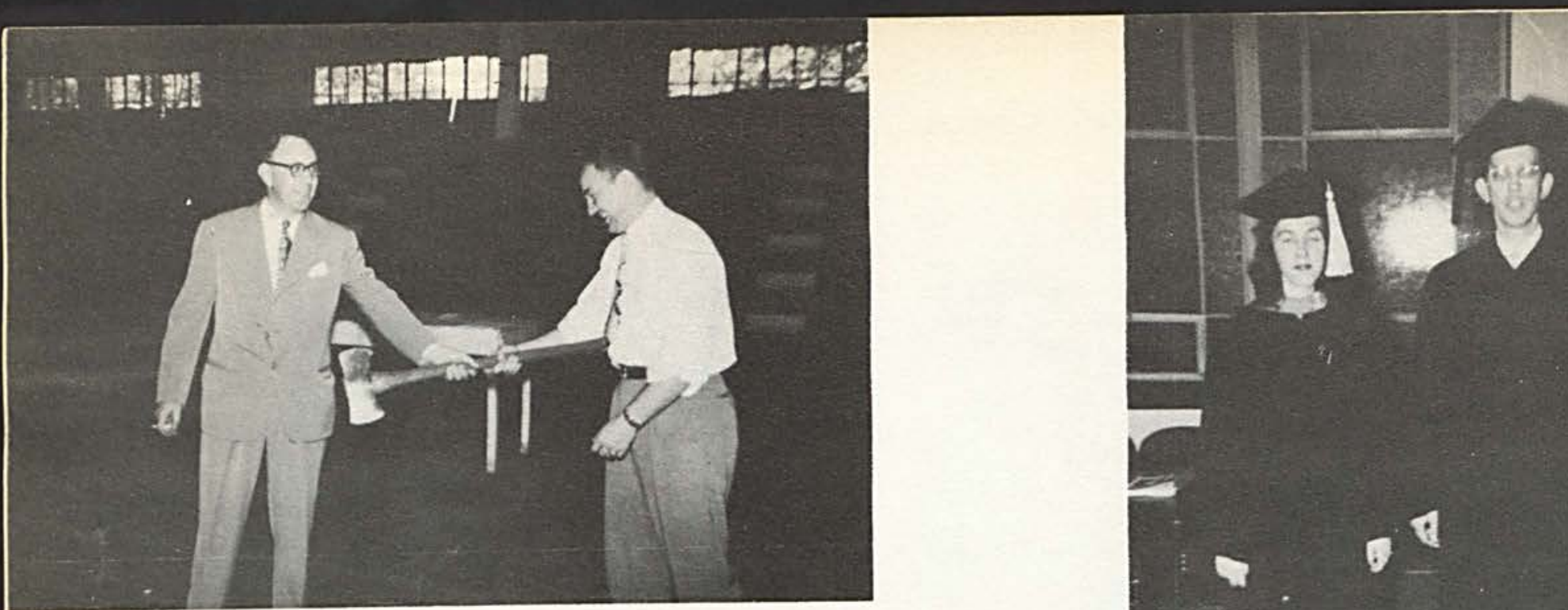

President Miller "Getting the Axe" from Frank Zirbel

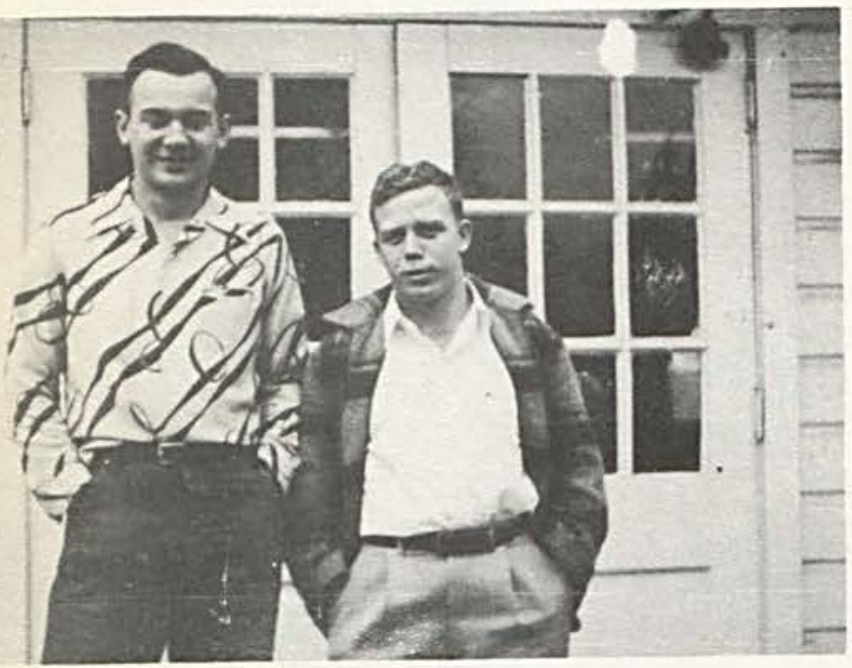

Graduates Frank Zirbel and Don Nock

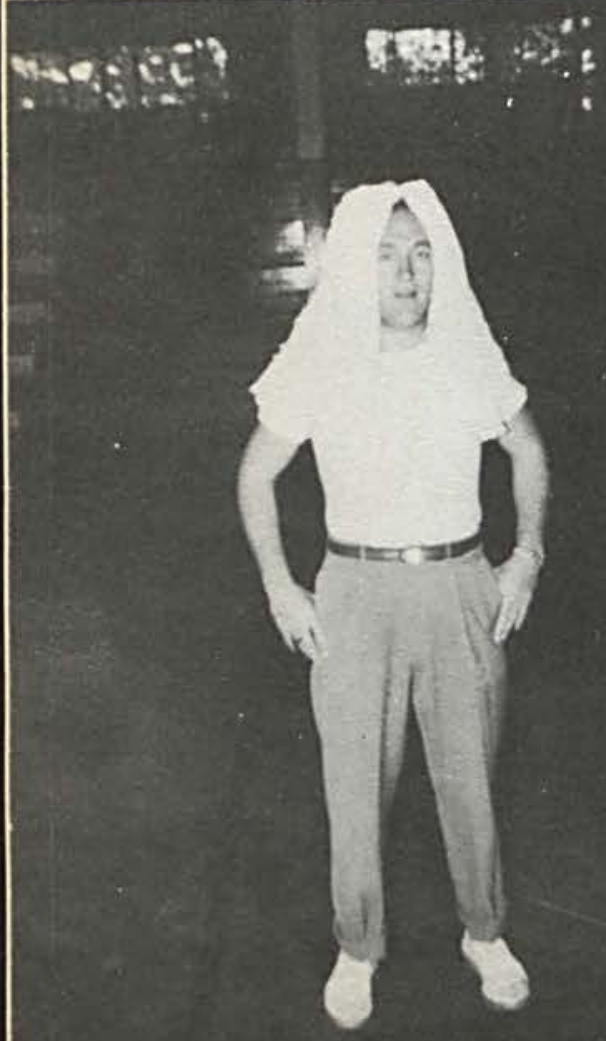

John Snowden

Portrays

Miss Randolph

Prof.

Bost

Myers

a $\frac{1}{3}$

Bost

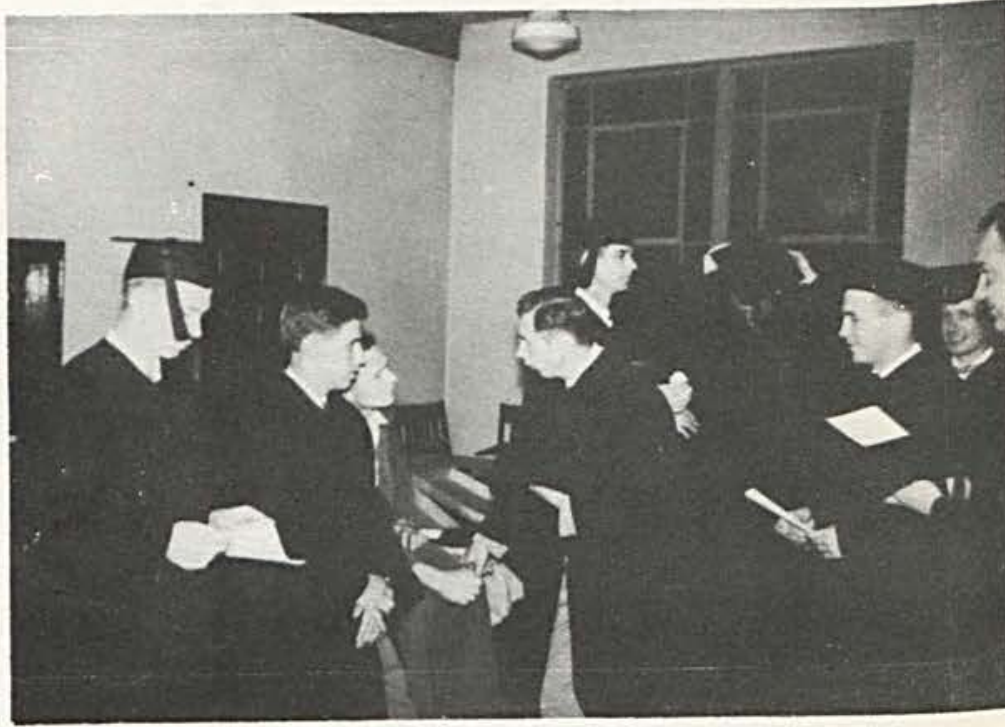

SENIORS

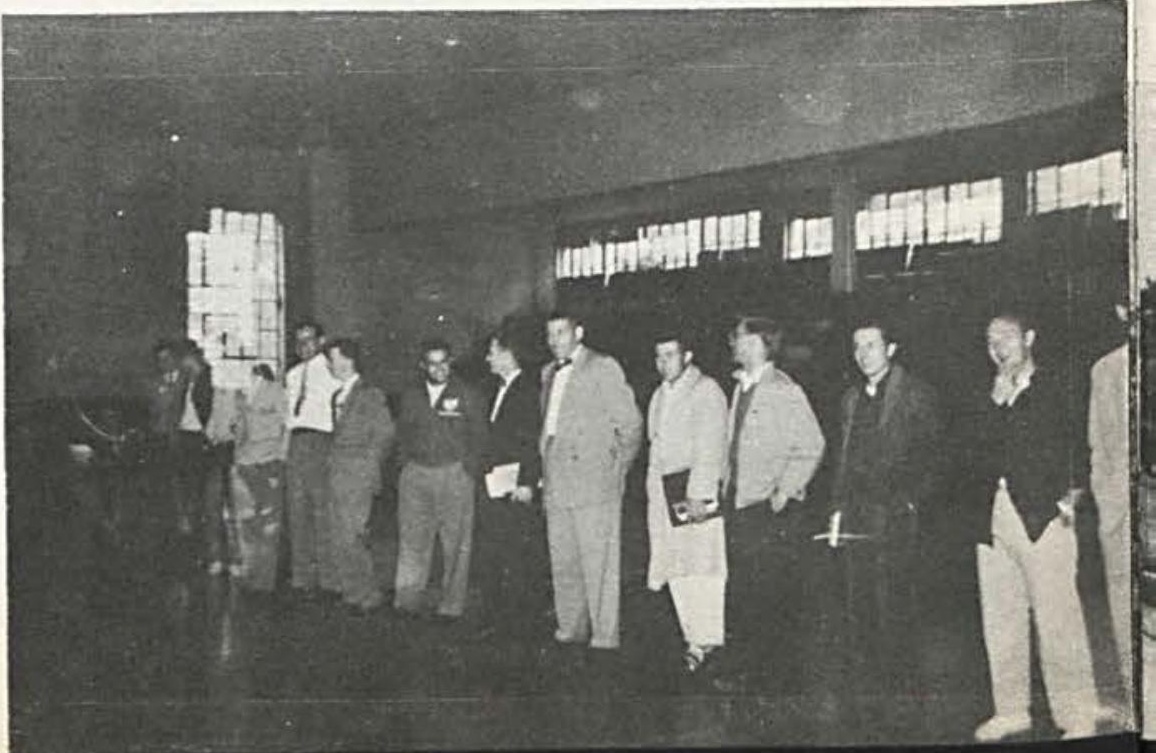




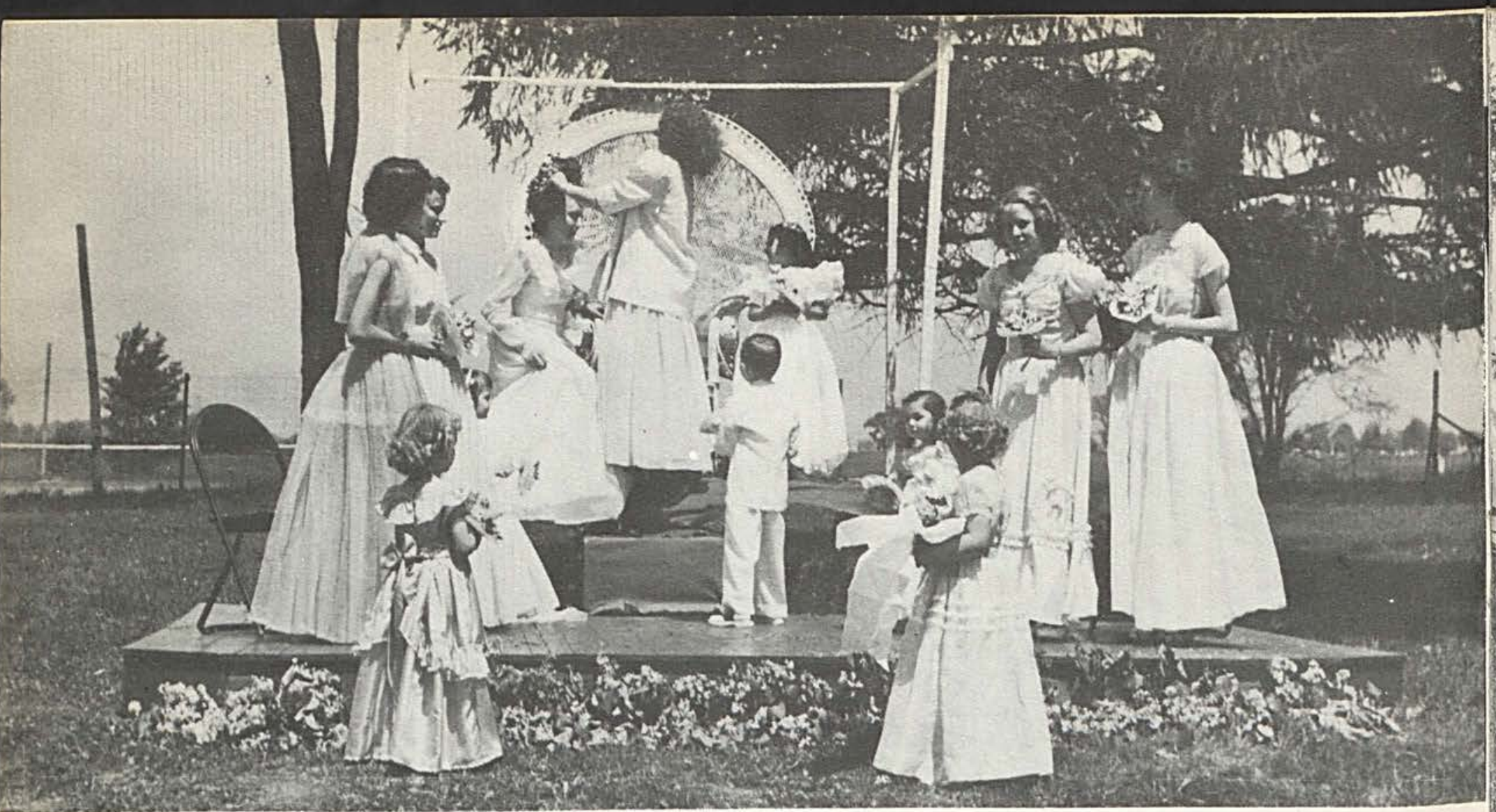

VIOLA THURMAN, 1950 QUEEN, CROWNS MARY FRENCH, 1951 CEDAR DAY QUEEN

MR. MILLER SPEAKS

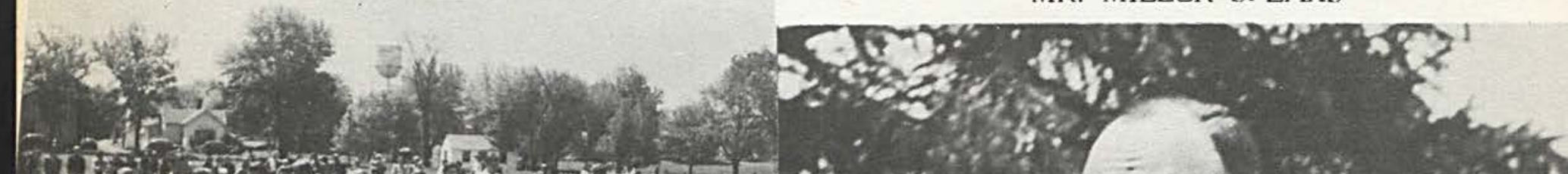

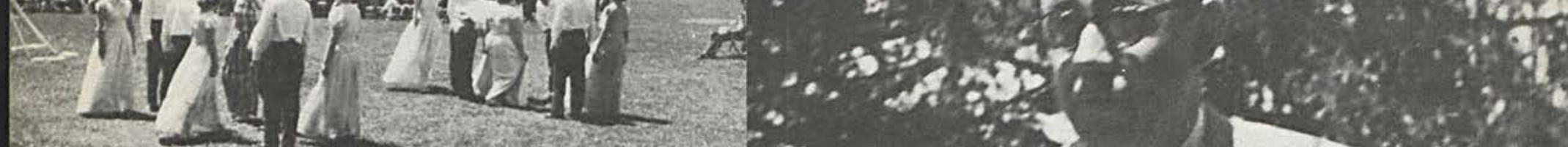

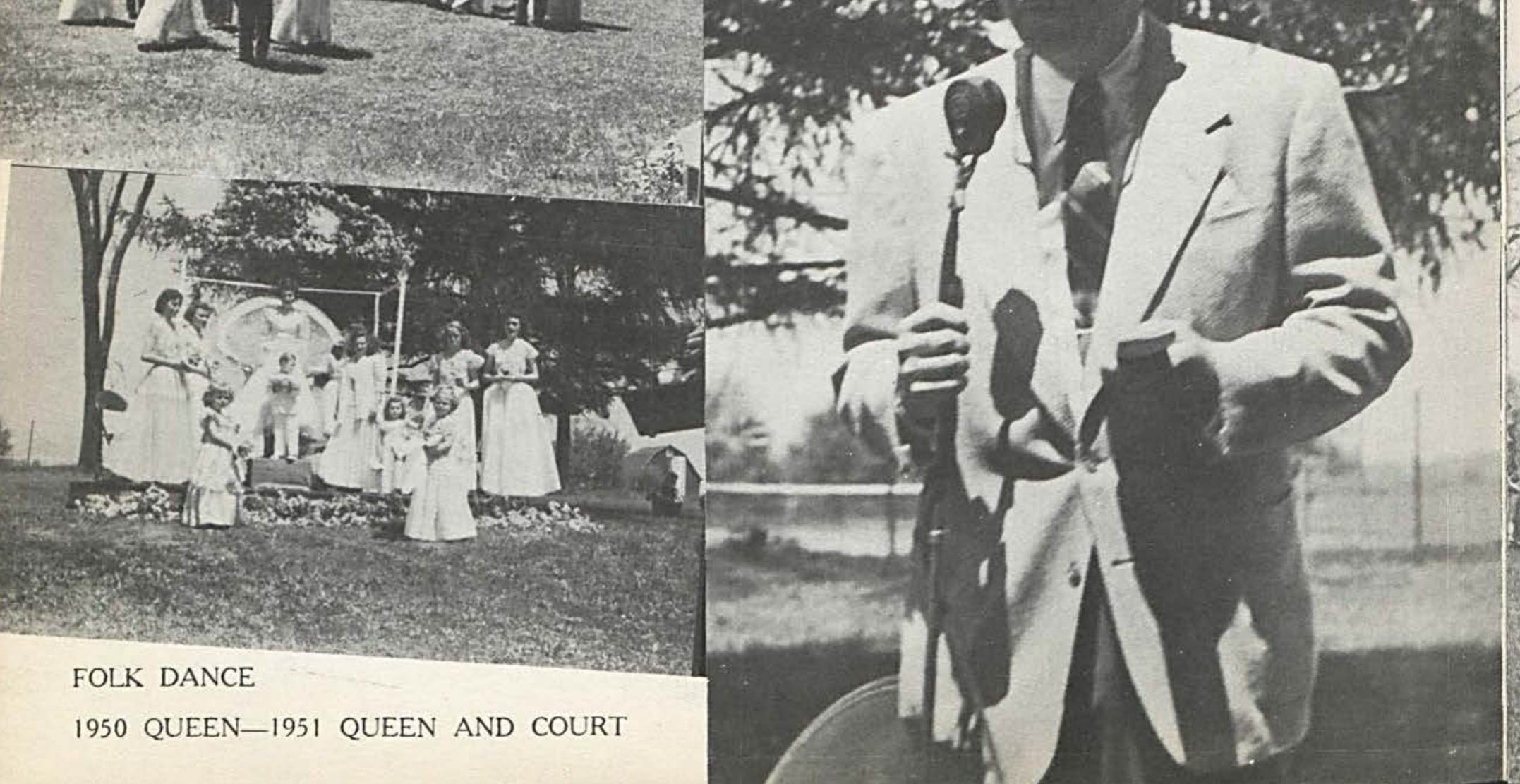




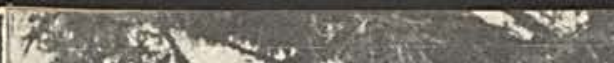

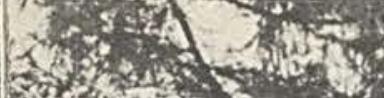

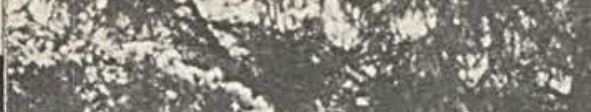

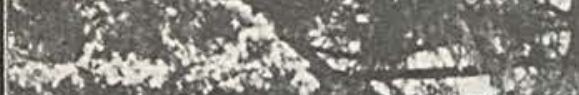
$+\infty$

s.

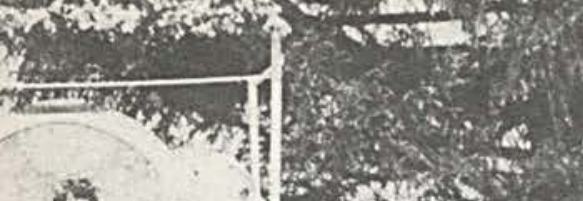

旁

(1)
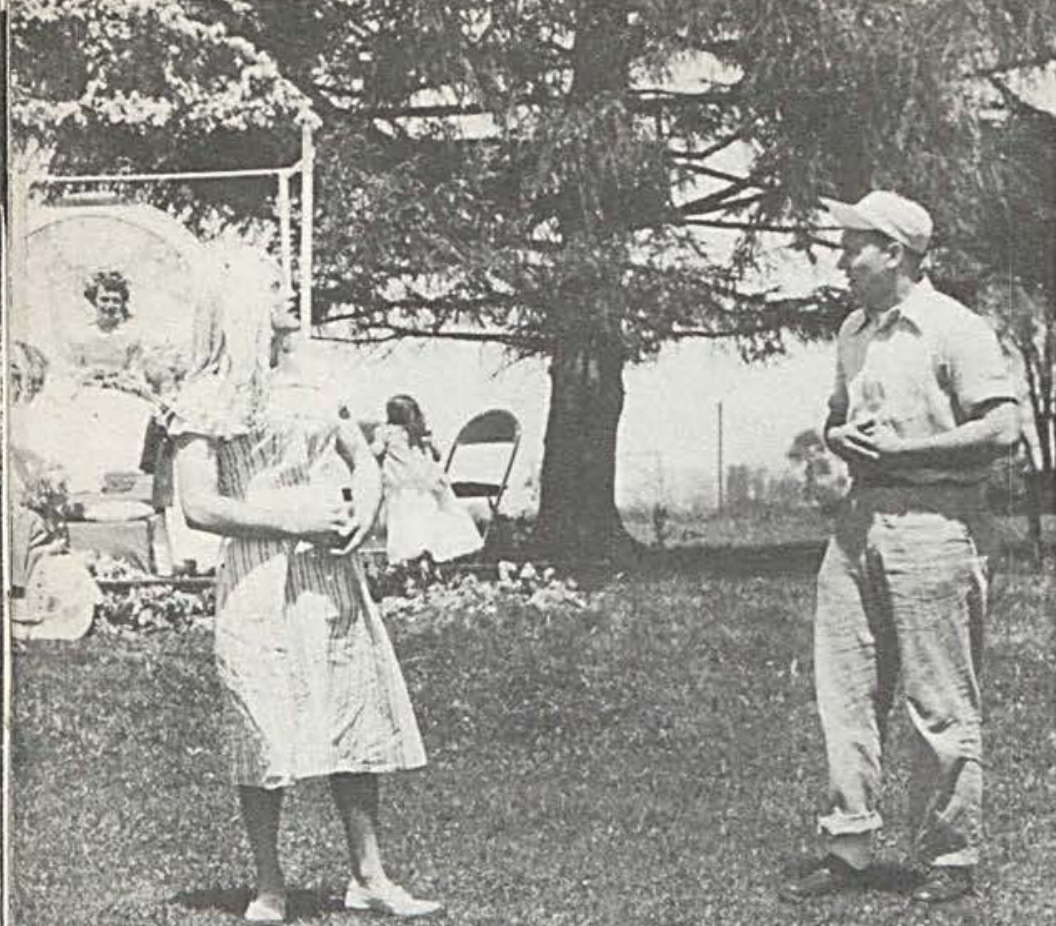

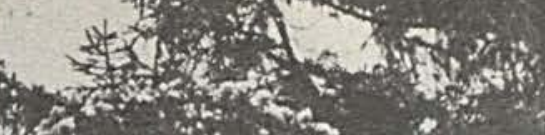

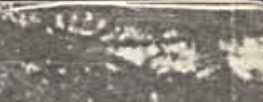

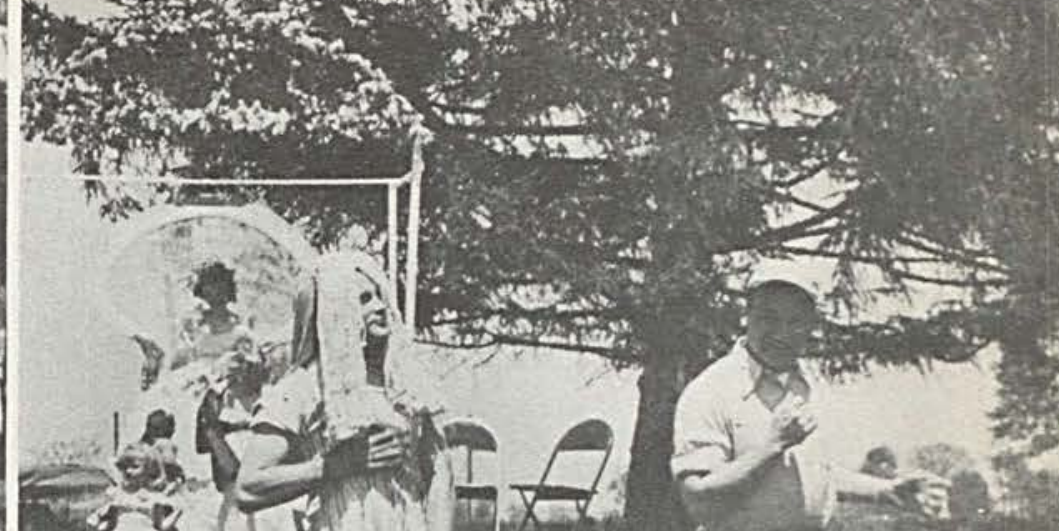

$\sin ^{2}$

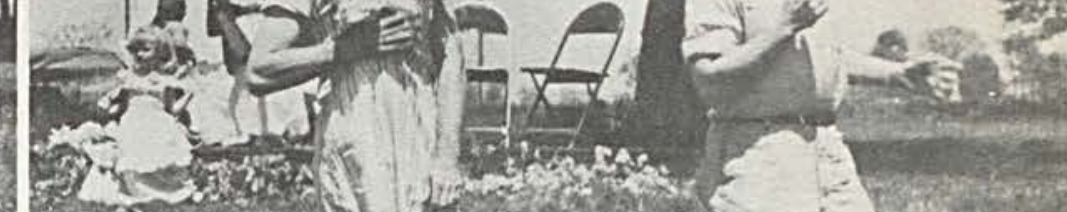

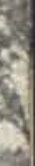

\section{Cedar Day Activities}

1. "JOHN, I CAN'T MARRY YOU TODAY!"

2. "AUF WIEDERSEHEN, MARY!"

3. A FOLK DANCE

4. MAY POLE DANCE

5. BASEBALL SPECTATORS

6. IMPERSONATIONS
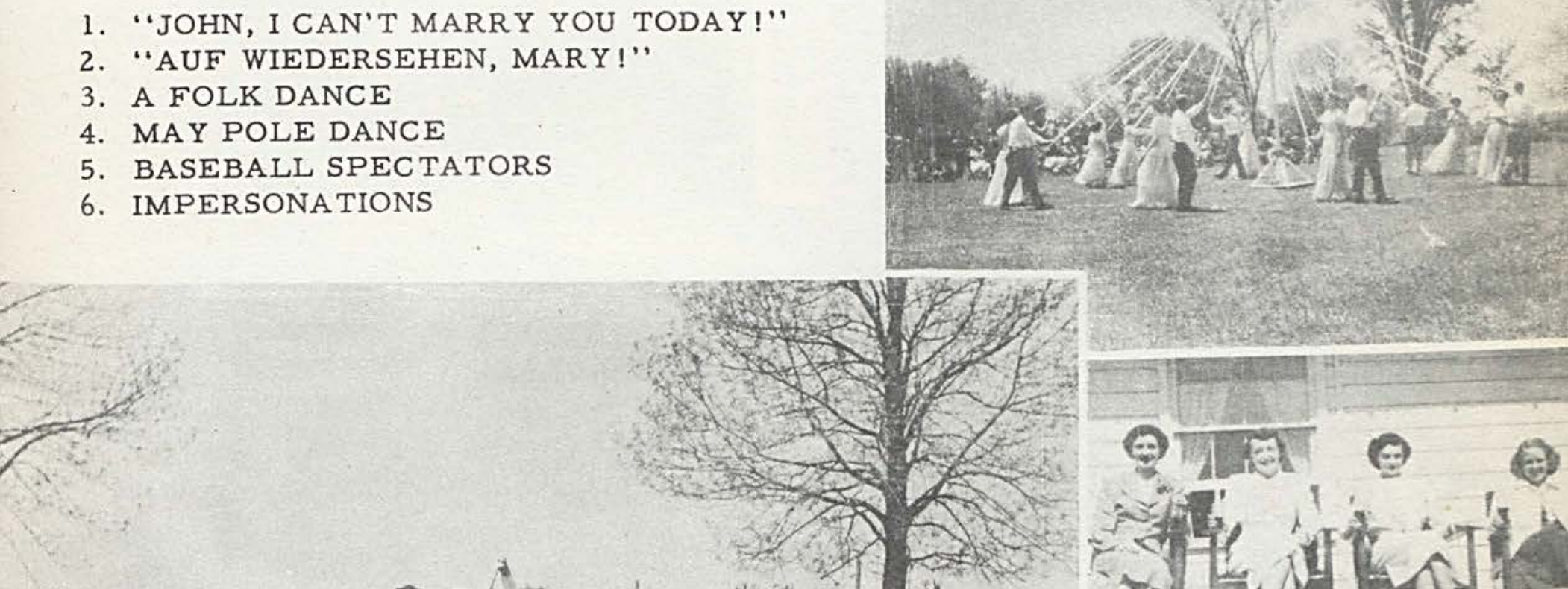

की

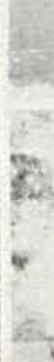
点 


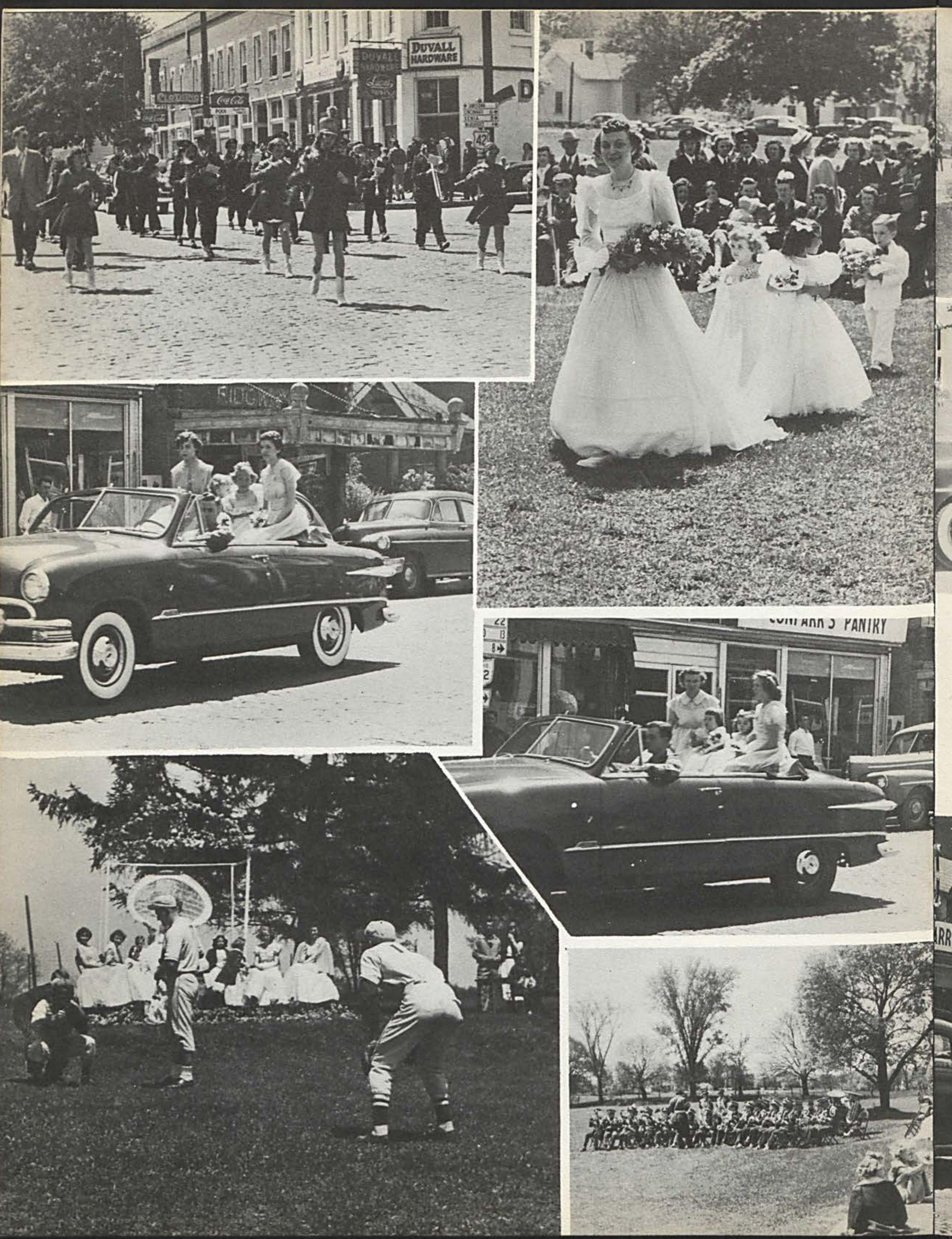




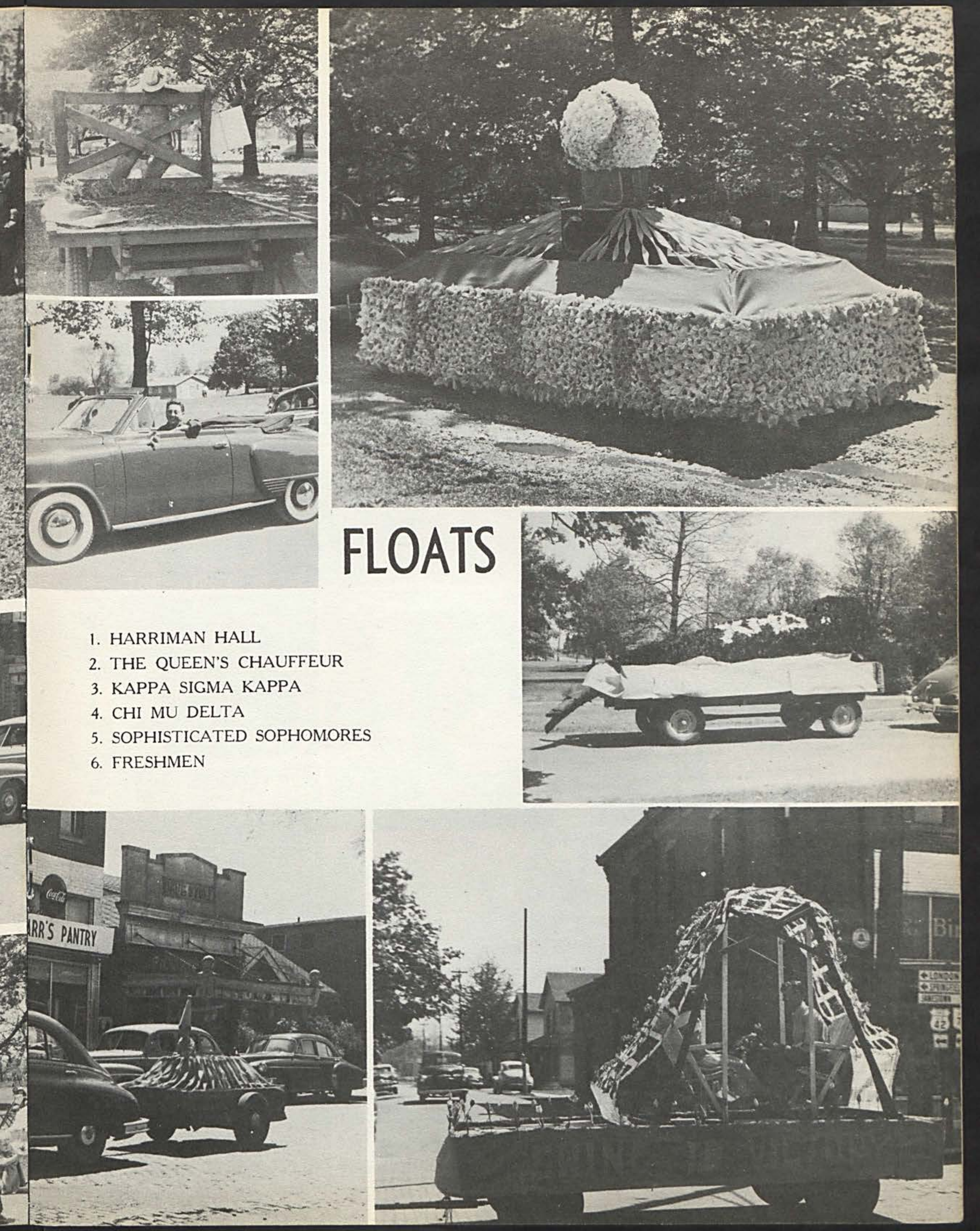





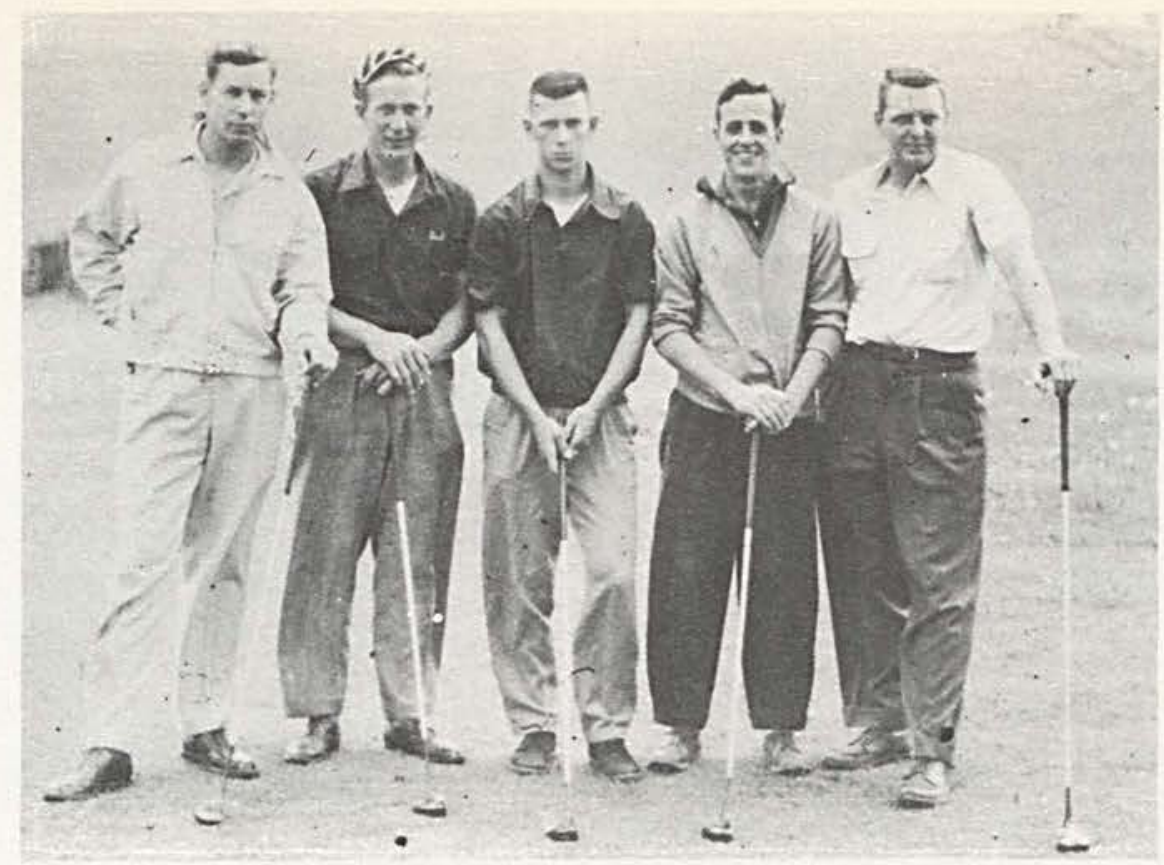

Left to Right: A. Scrivner, A. Goodwin, R. Hatfield, T. Webster, Capt. F. Long

\section{Golf 1951}

Despite Fred Long's sparkling play in the Mid-Ohio league golf meet at the Xenia Country Club course, the Yellow Jackets were unable to finish better than third. Defending champion Ohio Northern University repeated for the championship, posting a team total of 340. Ashland was second with 343; Cedarville third with 352.

Long won medalist honors with a 77 , three strokes better than his nearest competitor. He had tied for medalist honors in 1950. Other Cedarville scores were: Ed Goodwin, 88; Dick Hatfield, 93; and Tom Webster, 94. Ohio Northern scores were: $80,85,87,87$, while Ashland posted scores of $83,86,87,87$.

The Yellow Jackets, under the leadership of E. H. Miller, defeaied Ashland and lost to Ohio Northern in Pre-toumey matches. 


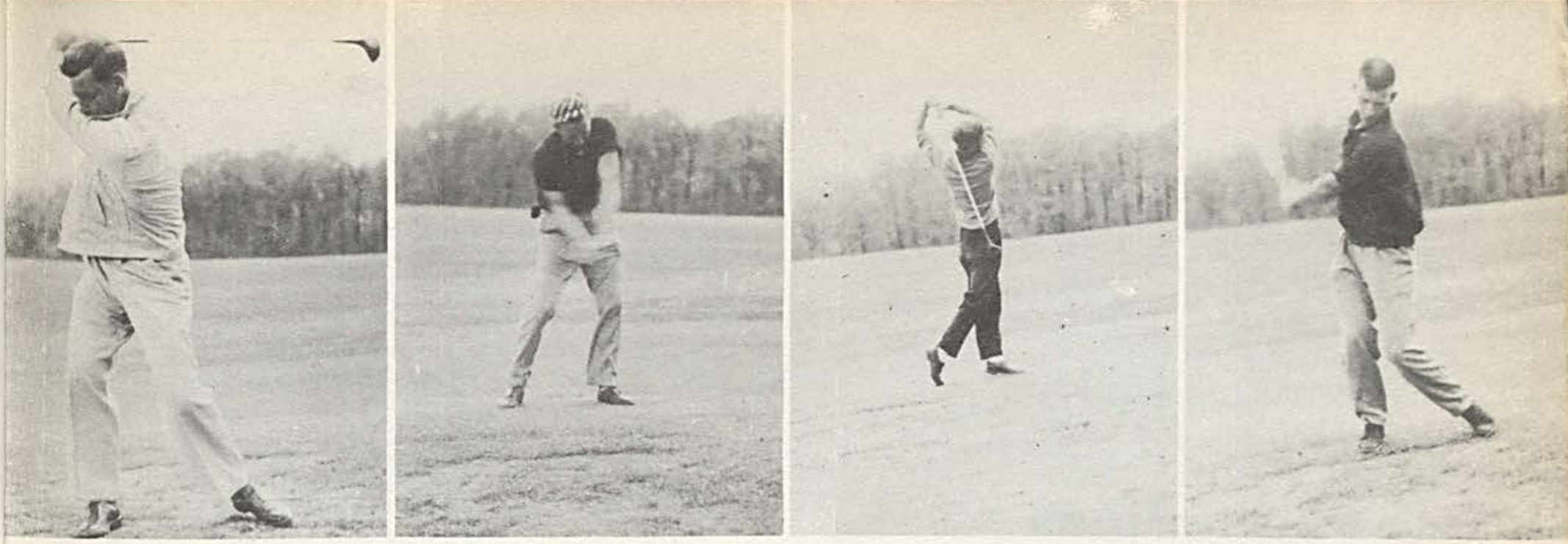

GOLF TEAM

DOC. JURKAT'S OFFICIAL POSITION

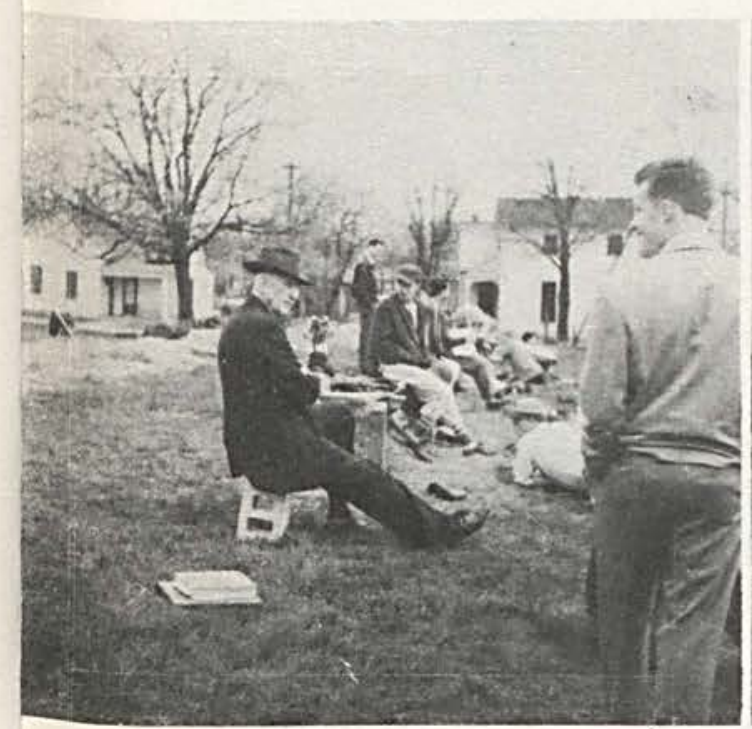

LUTTRELL AT BAT

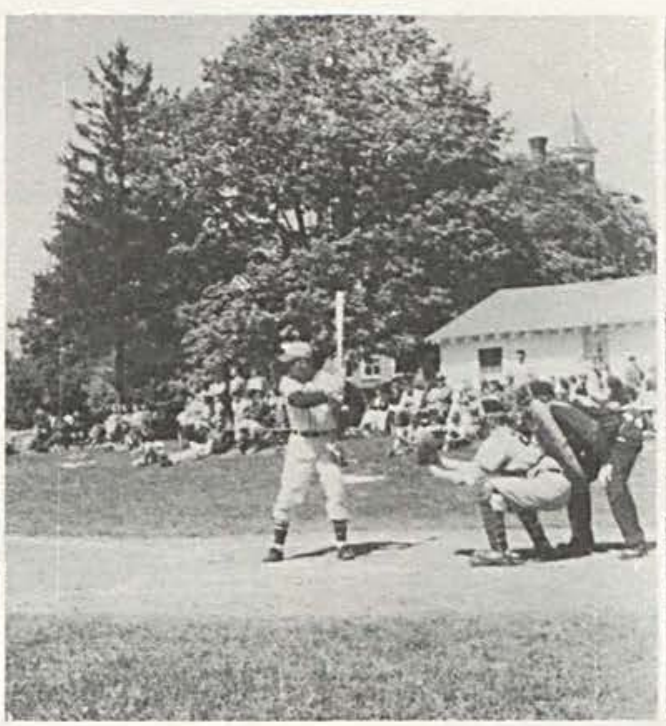

"STRIKE TWO!"

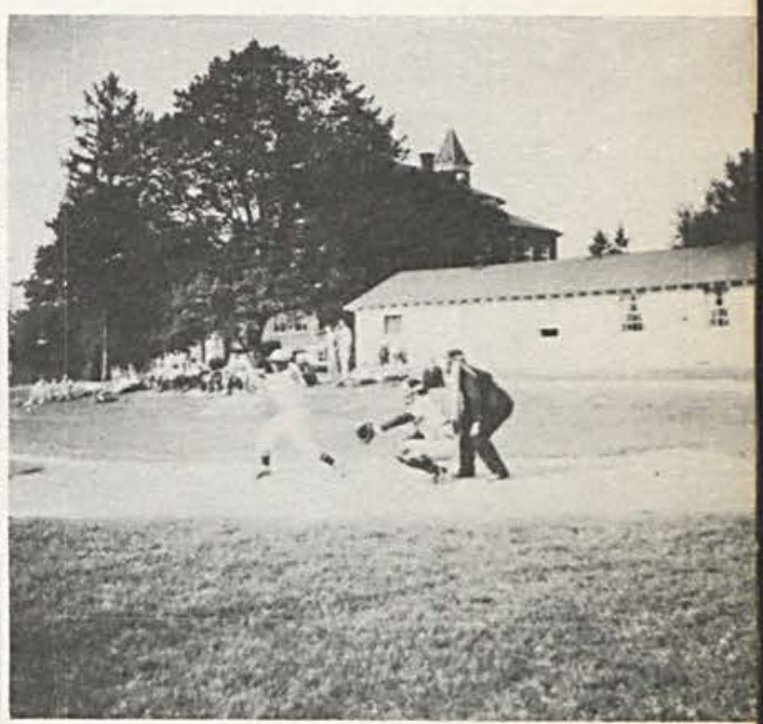

BASE HIT

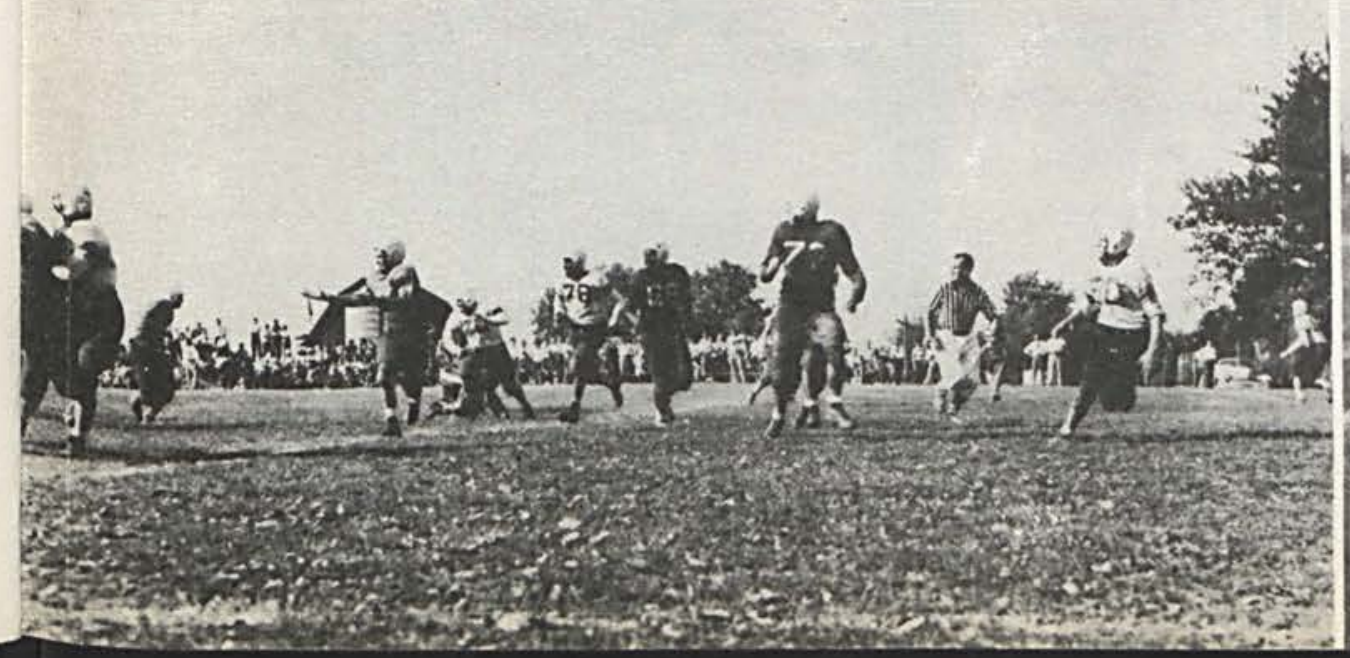



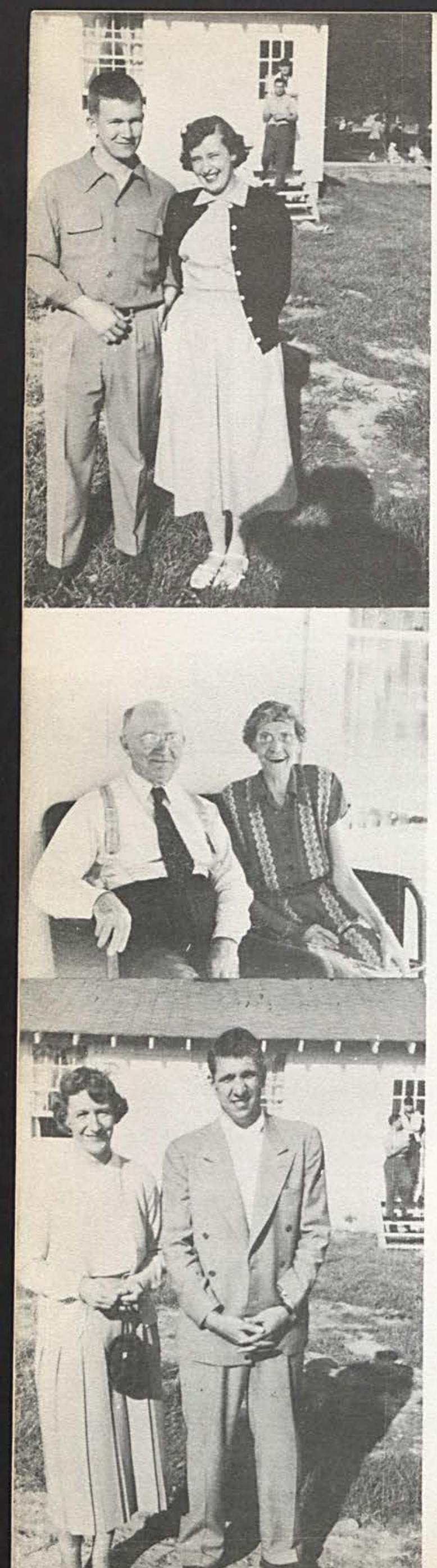

Aldon Justus '50

Dorothy Davis

(Cadet) '49

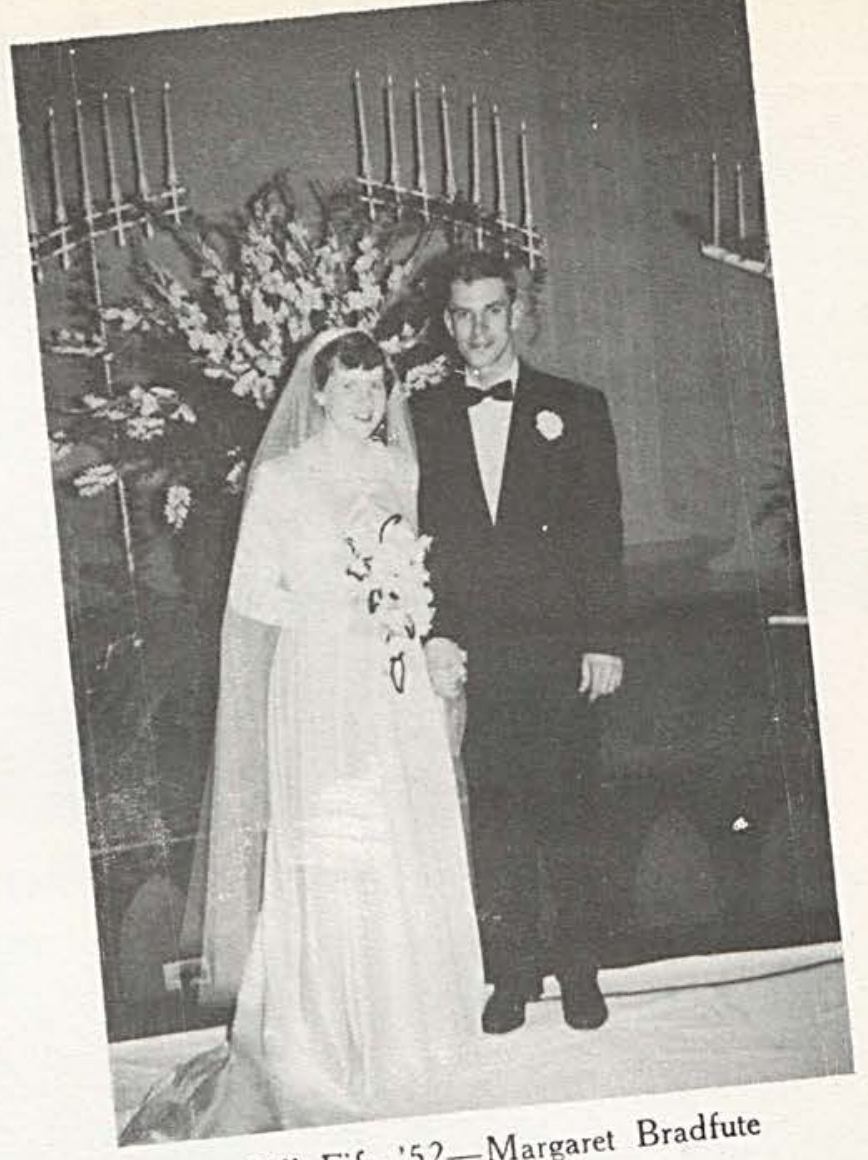

Bill Fife 52-Margaret Bradfute

Rev. Ralph Jamieson

Carrie M. Rife '04

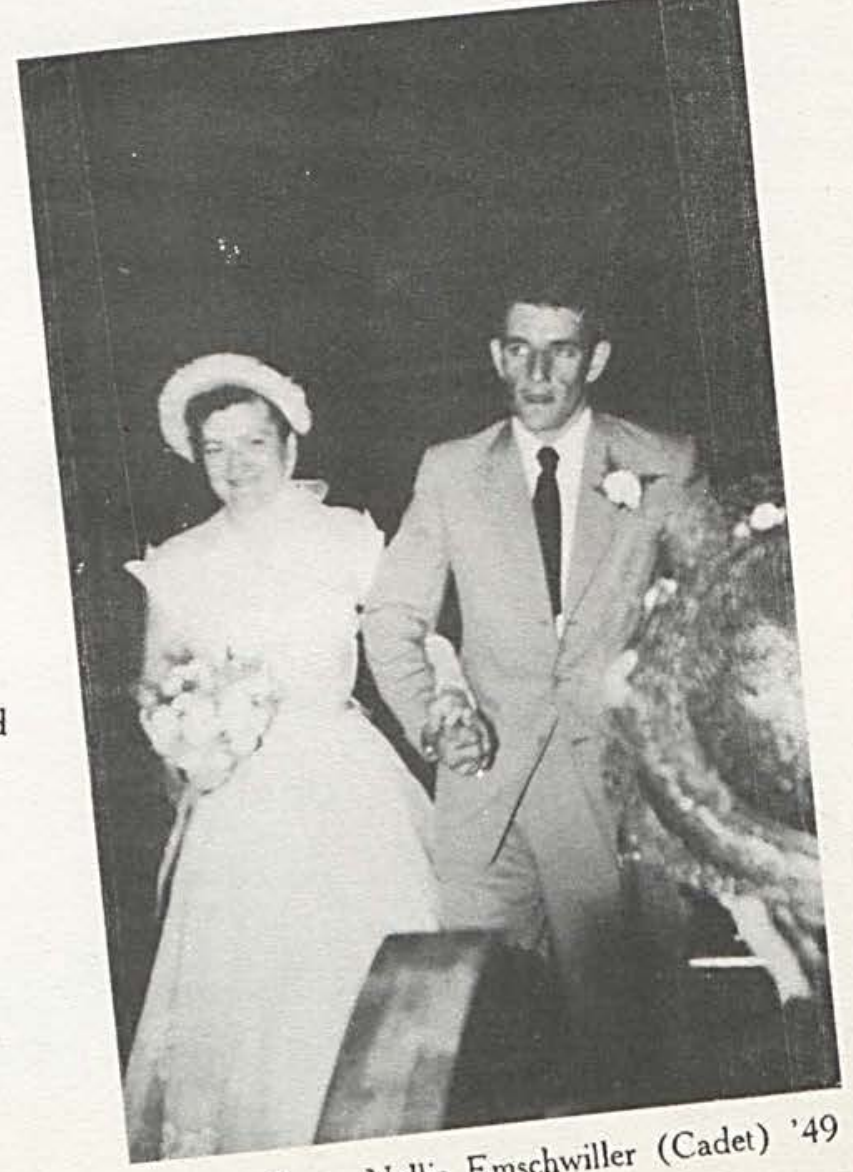

Robert Burt-Nellie Emschwiller (Cadet) '49
Walter Blateric '50

Prof. Edith Stangland 


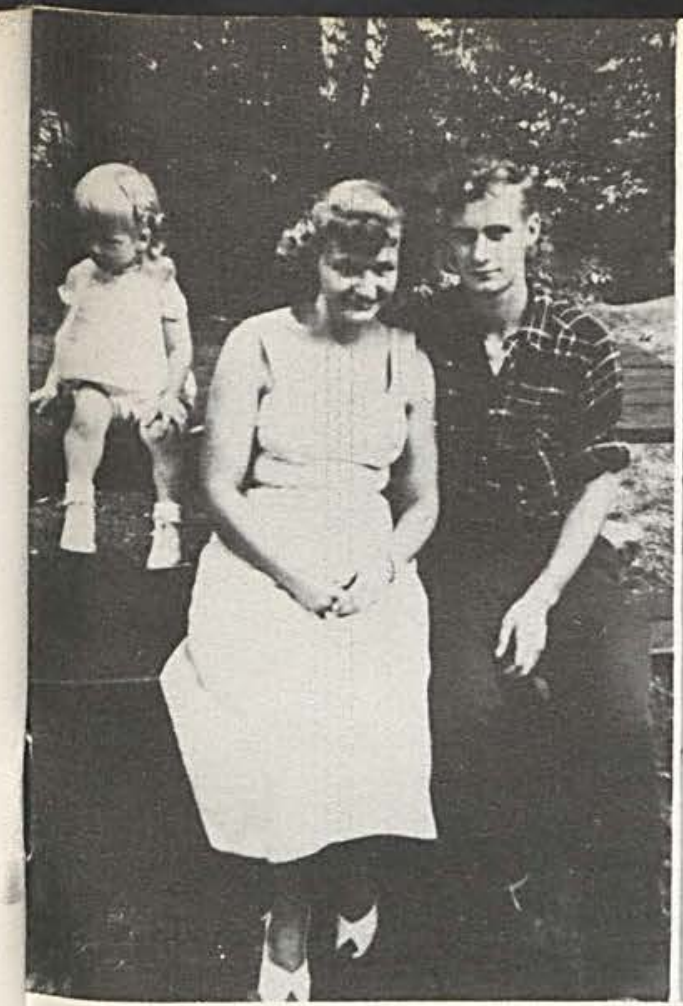

Robert Meade

Joan Sanderson, Cadet ' 50

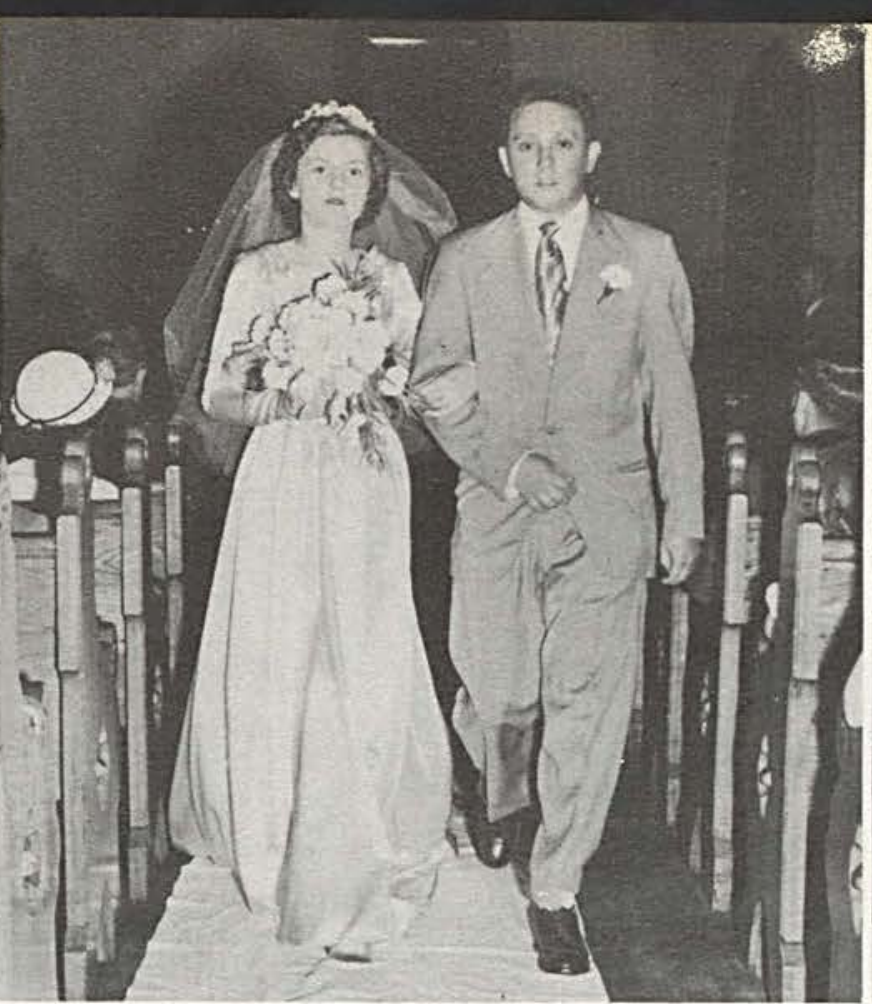

Harold Warix ' 49

Mrs. Harold Warix

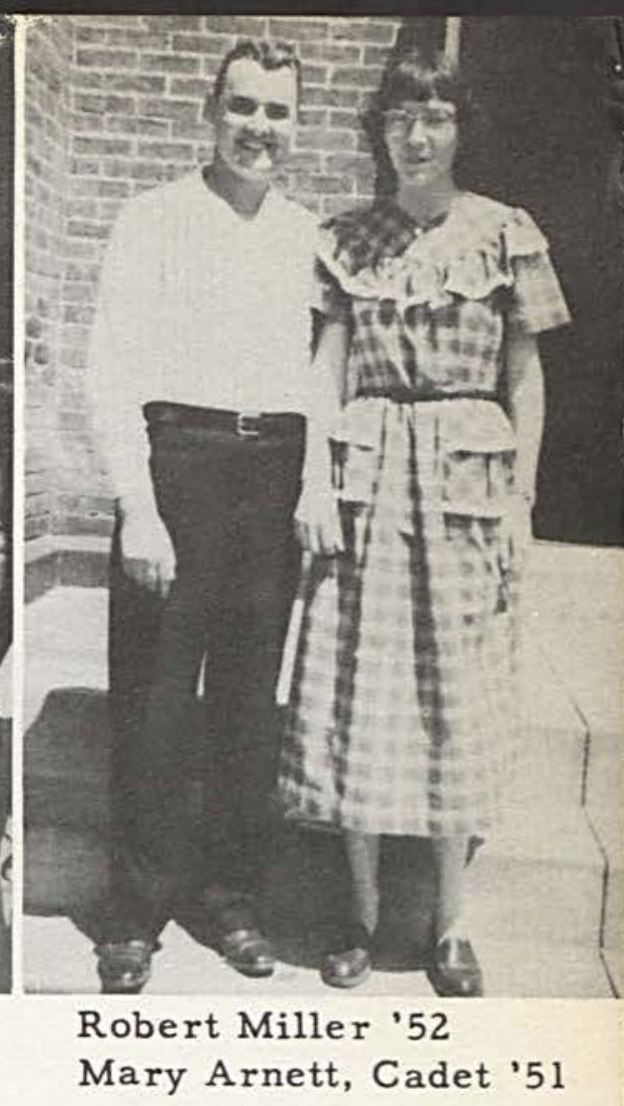

During the past year there have been numerous weddings. A few pictures were obtained in time for publication. In the cases of Mr. and Mrs. Burt and $\mathrm{Mr}$. and Mrs. Nock a third member has been added. Though most of the school was surprised by Dave and Rosie the Cedrus Staff anticipated the event. While one might miss a whirlwind he certainly should be able to see a tornado approaching.

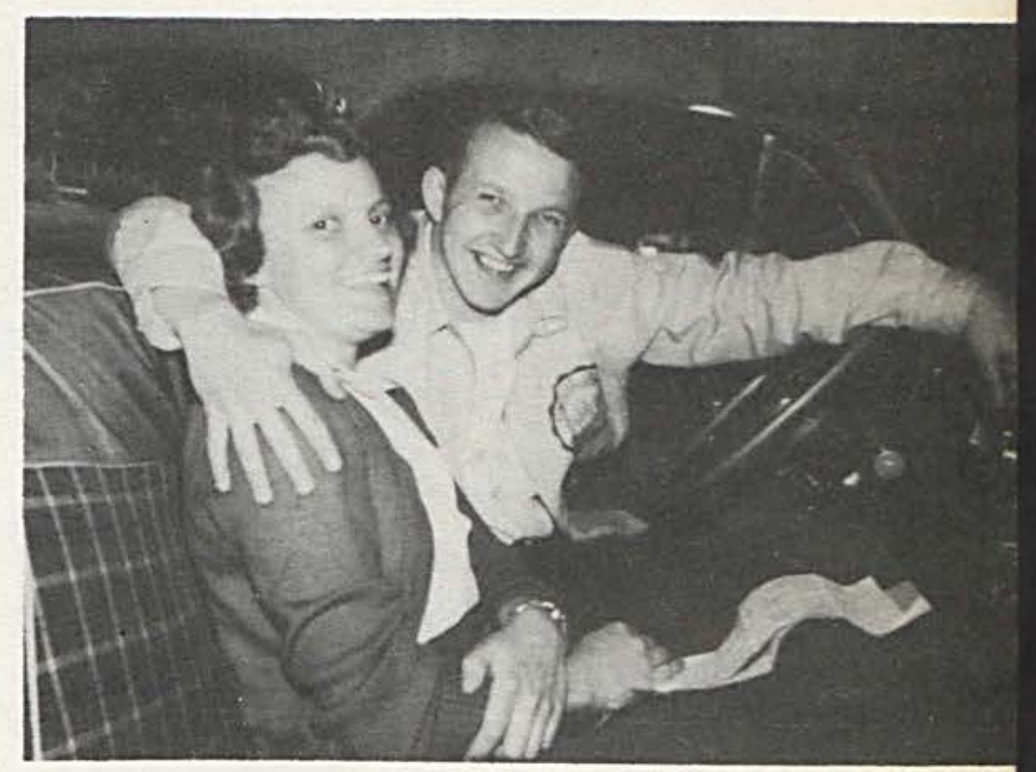

Dave Spitzer ' 52

Rosie Miller, Cadet ' 52

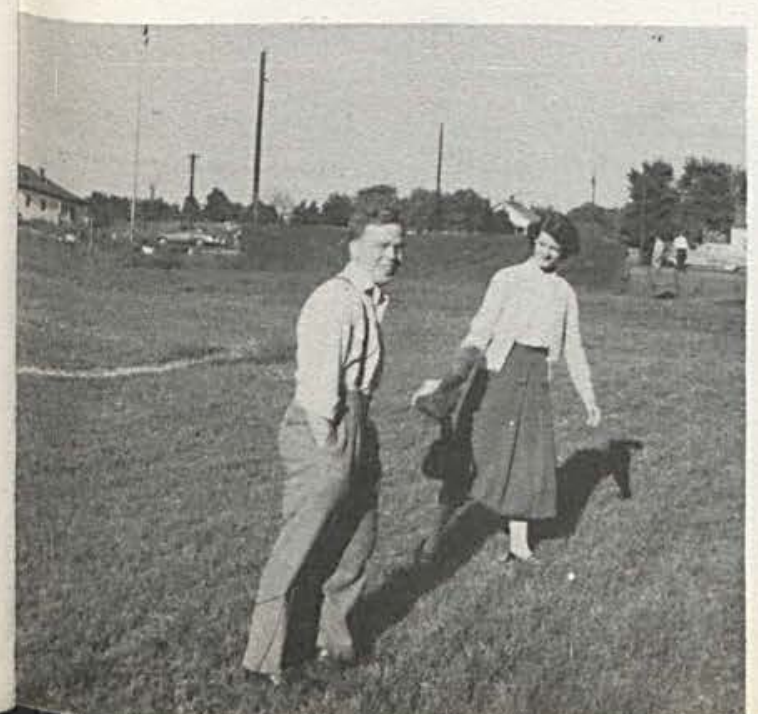

Donald Nock' 51

Rosemary Elam, Cadet '49

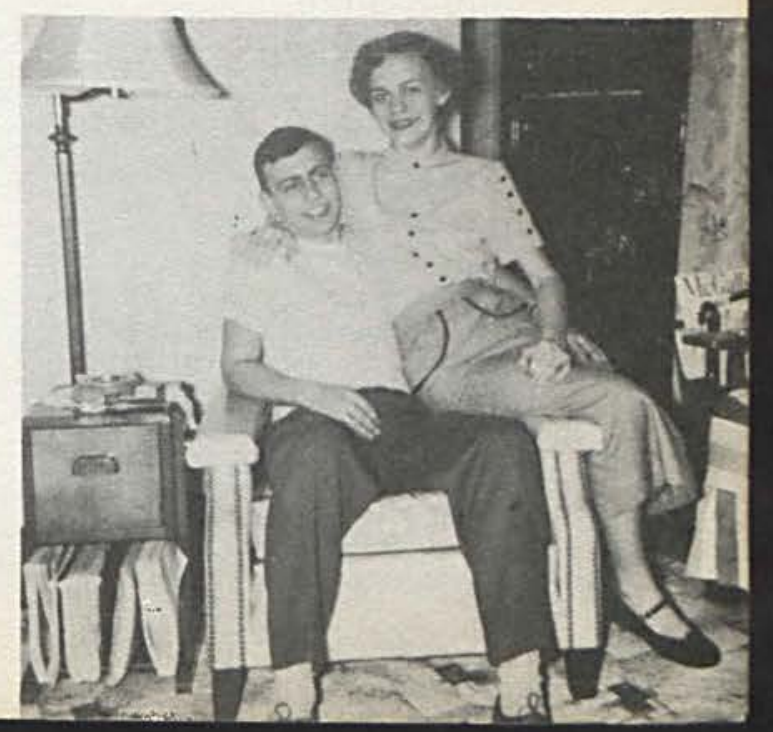




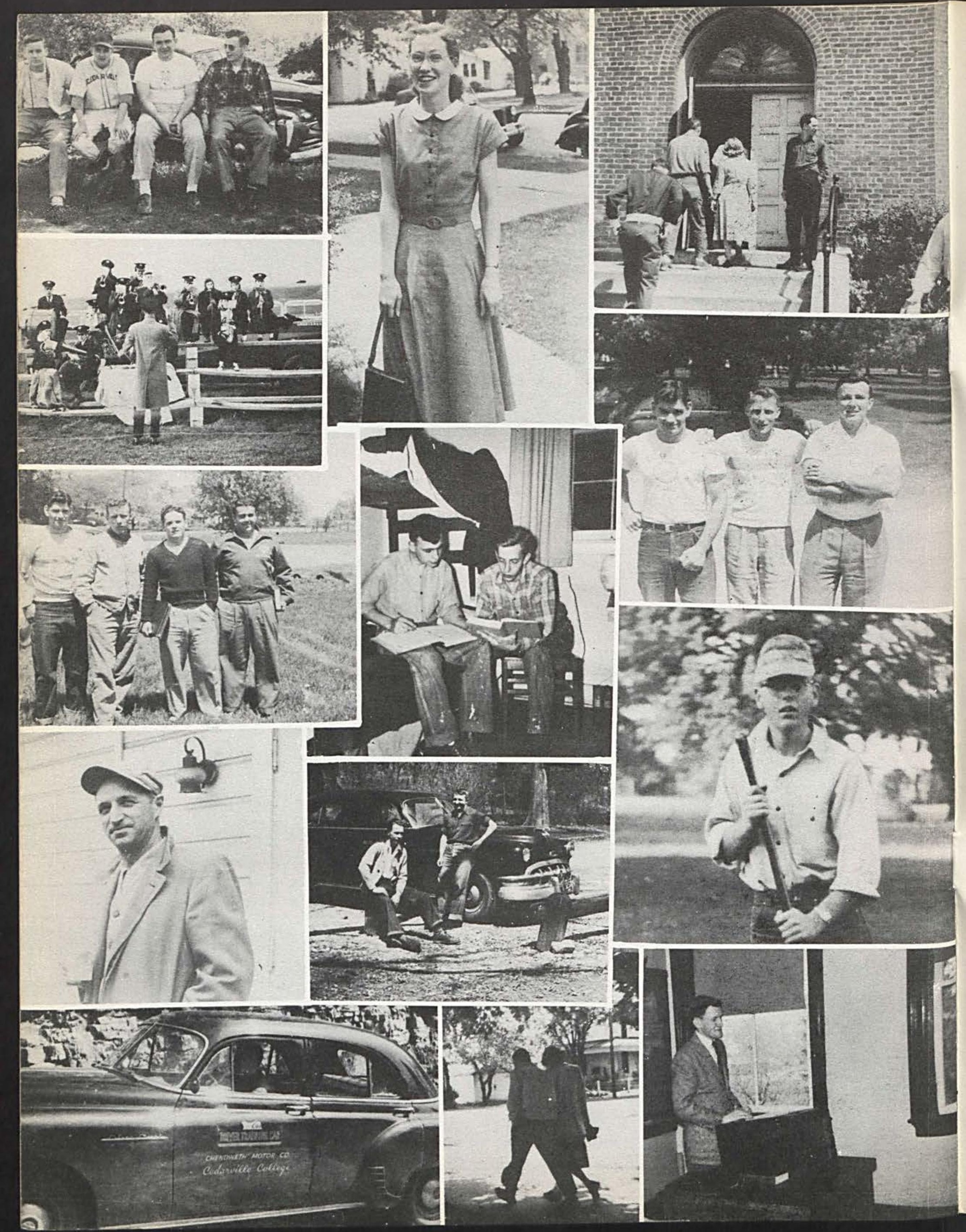




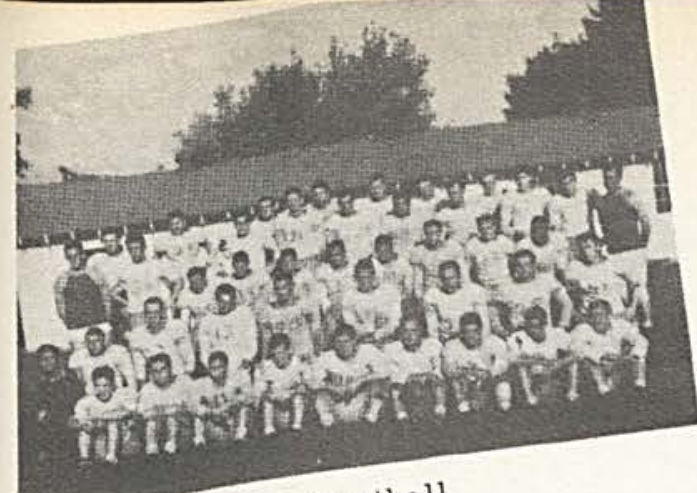

Eootball

reco sporting goons

113 East High St.

Springfield, Ohio

Baseball

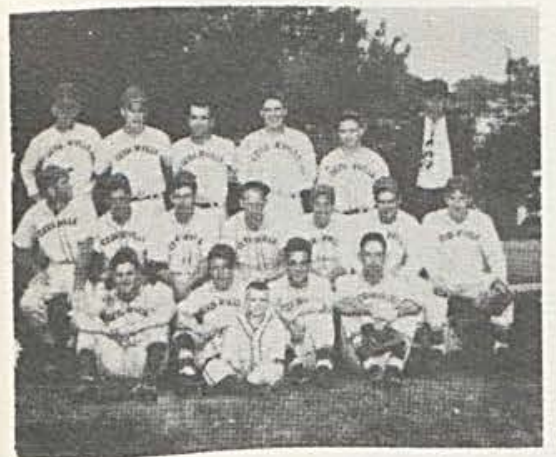

Golf

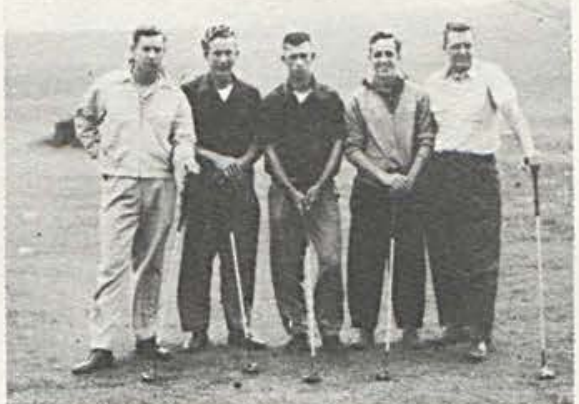

Tennis

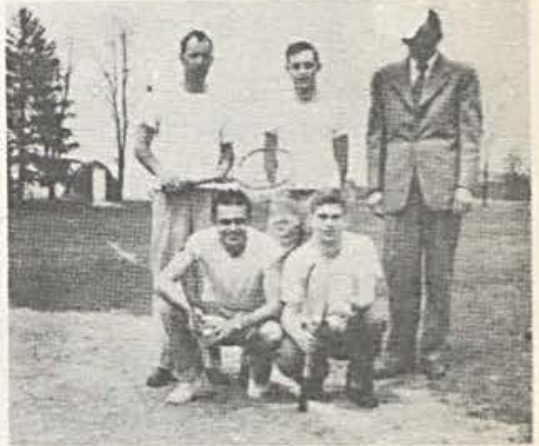

\section{Concord Provision Company}

\section{Dayton, Ohio}

- A Complete Service -

Groceries, Meats, Fresh Fruits, Vegetables \& Supplies for Hotels, Restaurants \& Institutions

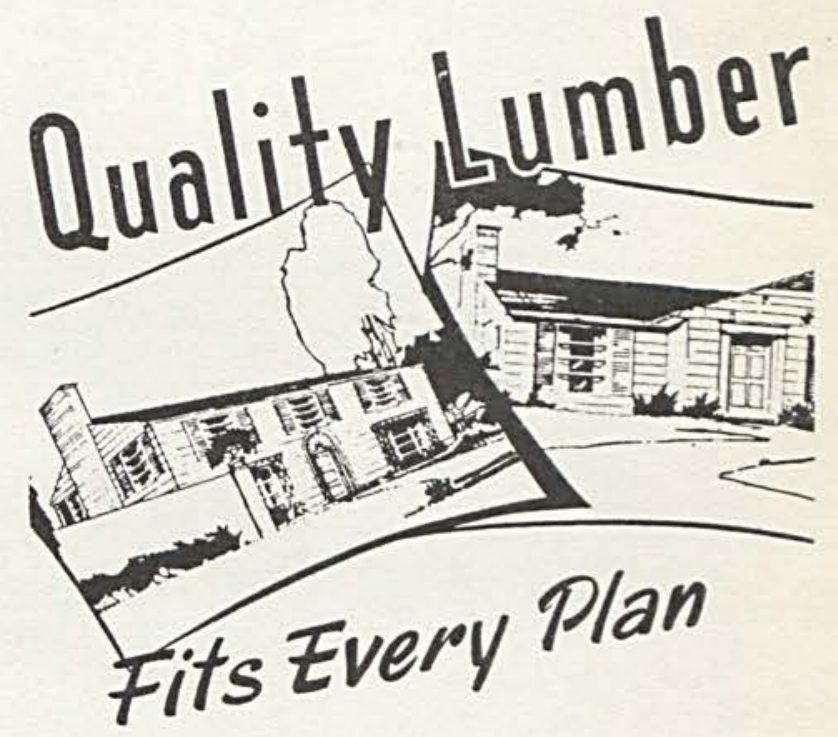

CEDARVILLE LUMBER CO.

"Dedicated to Serve"

6-1331 CEDARVILLE, OHIO 


\section{Farm Bureau Insurance Service}

Bertha S. Stormont, Agent

R. R. \#5, Xenia, Ohio

Phone: Xenia, 1301 M-3
H. E. Ullery, Prop.

J. H. RANDALL, Mgr.

\section{ULLERY'S ELEVATOR}

CEDARVHIL, OHIO

Phone 6-2021

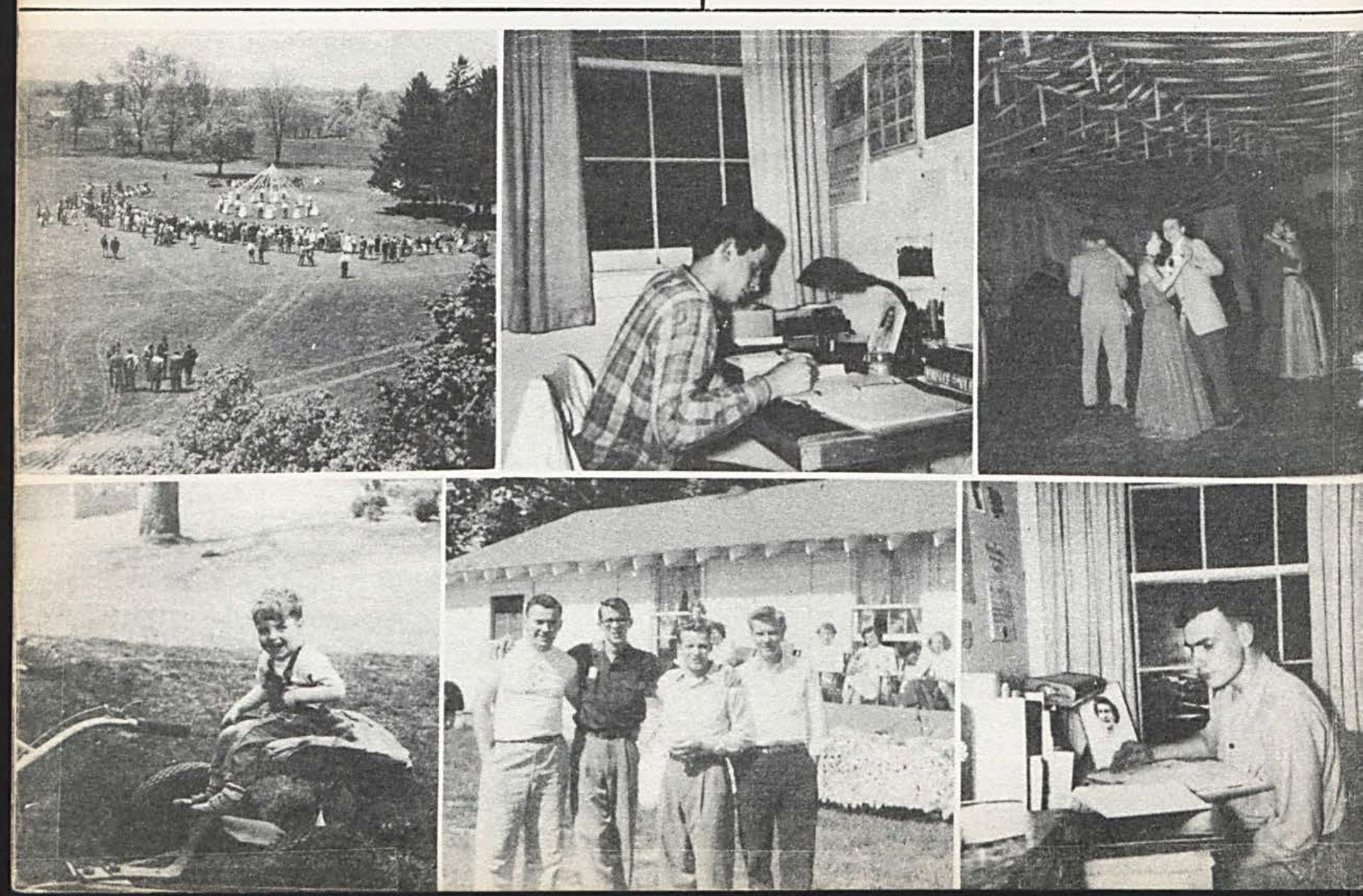







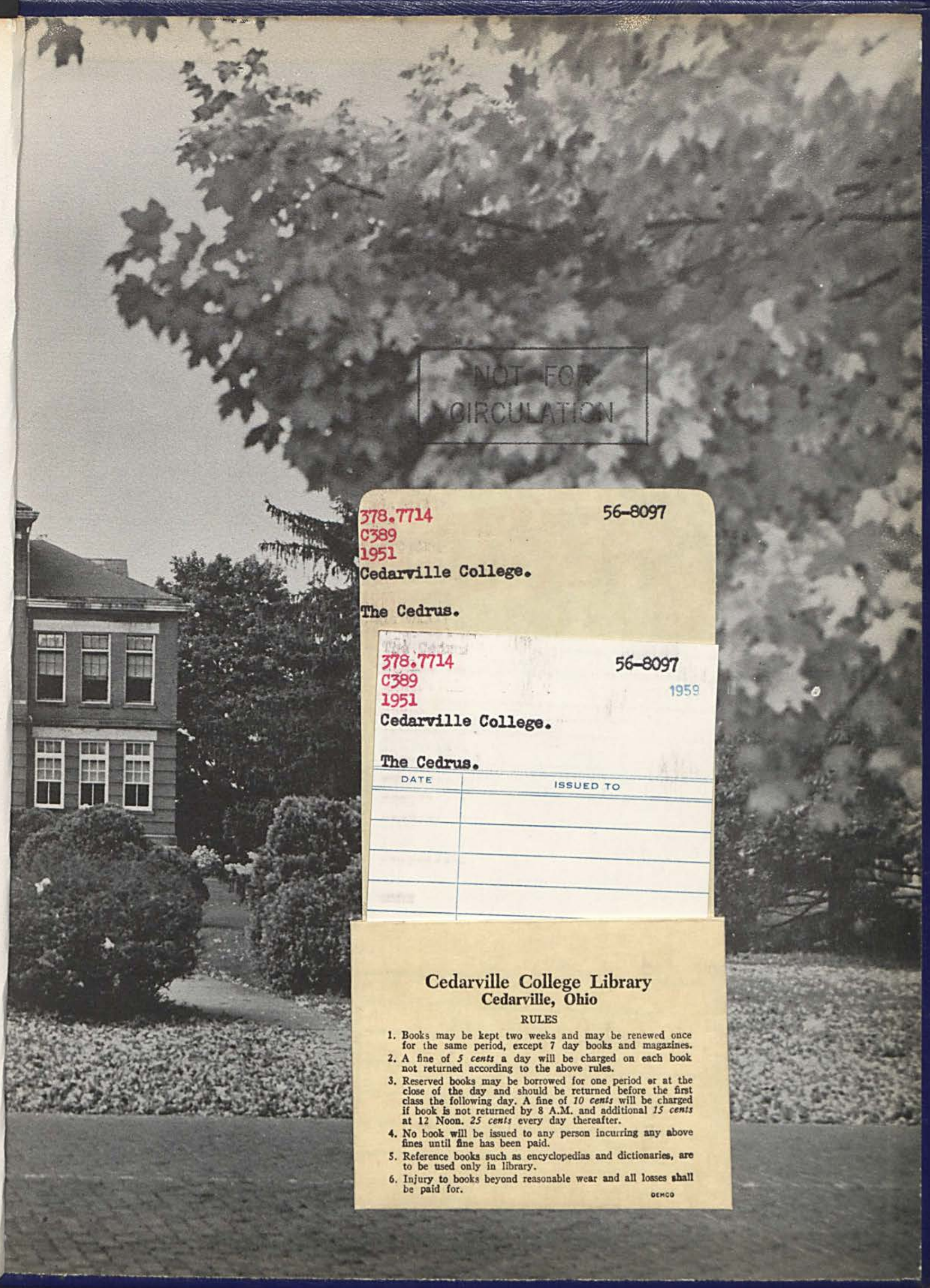





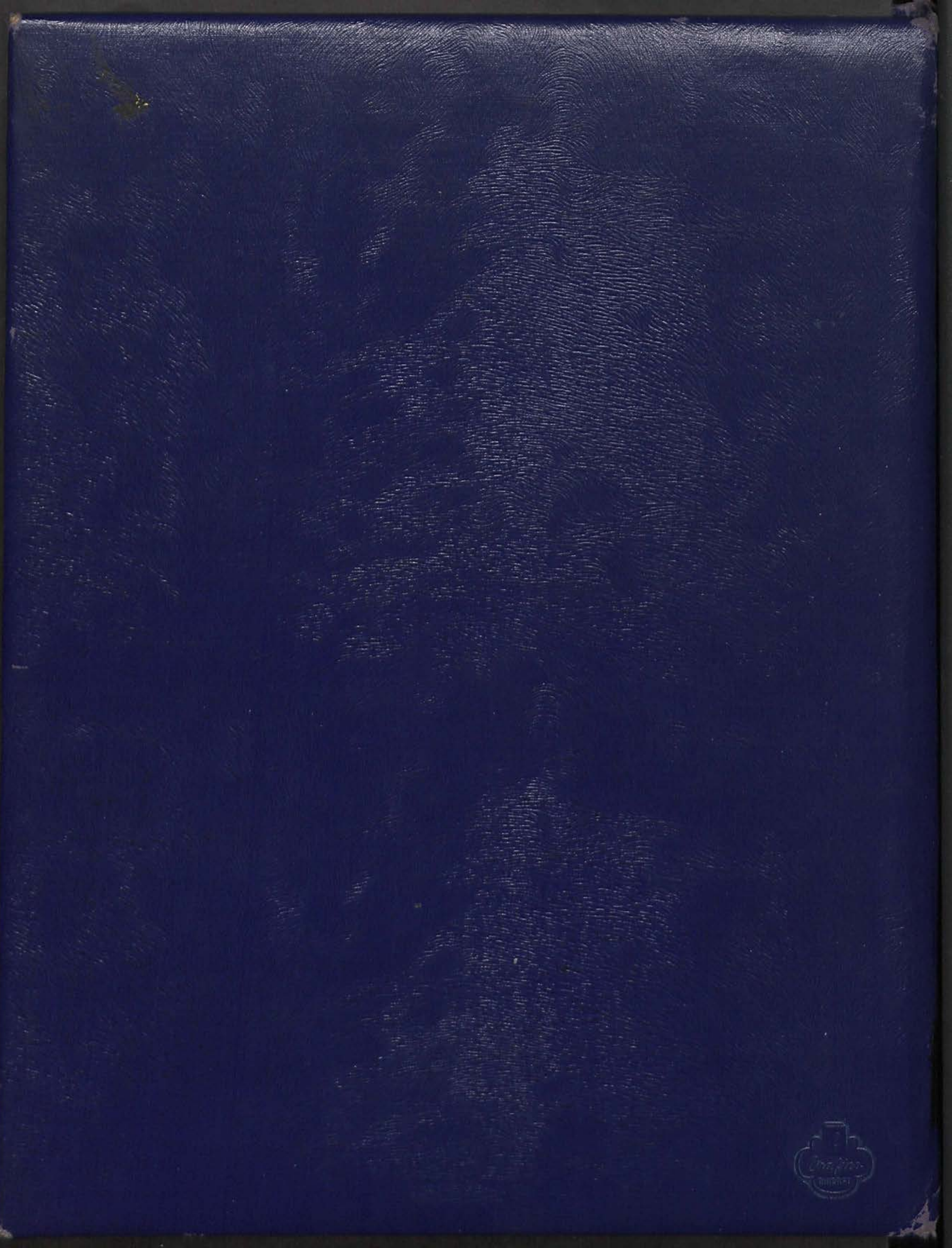

